JULIANNA NUNES TARGINO BARBOSA

A CULPABILIDADE NA RESPONSABILIDADE PENAL DA PESSOA JURÍDICA

\author{
DisSertaÇão de MeSTRAdo
}

Orientador: Professor Titular Renato de Mello JORge Silveira

FACULDADE DE DIREITO DA USP

SÃO PAULO

2014 
JULIANNA NUNES TARGINO BARBOSA

\section{A CULPABILIDADE NA RESPONSABILIDADE PENAL DA PESSOA JURÍDICA}

Dissertação de Mestrado apresentada à Banca Examinadora da Faculdade de Direito da Universidade de São Paulo, como exigência parcial para a obtenção do título de Mestre em Direito, sob a orientação do Prof. Titular Renato de Mello Jorge Silveira.

FACULDADE DE DIREITO DA USP

SÃO PAULO

2014 
Banca Examinadora 
Aos meus pais, por sempre sonharmos juntos. 


\section{AGRADECIMENTOS}

Infelizmente, as palavras não bastam para encerrar a gratidão que sinto. Aliás, quando mais se fazem necessárias é que elas me faltam. Mas, se é a palavra o instrumento que me cabe agora, é por meio dela que, sempre de forma menor do que a devida, irei agradecer.

Agradecer, em primeiro lugar, aos meus pais, Julia e Rui, exemplo de superação e dedicação, que me ensinaram a pensar muito além dos limites do possível. A eles, mais do que minha gratidão, meu eterno amor, por me fazerem sonhar e concretizar os sonhos.

Ao meu irmão, Murillo, muito obrigada pela existência que ilumina minha vida com suas renovadas ideias, com seu humor "peculiarmente nosso", e com sua indignação com o mundo.

Ao meu orientador, Professor Renato de Mello Jorge Silveira, minha gratidão por, ainda nos bancos da graduação, ter inaugurado em mim o interesse pelo Direito Penal e por fomentar esse interesse - que hoje é vício - ao longo desses anos.

Minha imensa gratidão, também, às colegas Beatriz Corrêa Camargo e Ana Carolina Carlos de Oliveira, pelo inestimável auxílio que facilitou a pesquisa na Universitat Pompeu Fabra; a Iván Navas Mondaca e Lorena Varela, pela paciência e disposição em me receber em Barcelona; e ao Professor Ricardo Robles Planas, meus agradecimentos pelas orientações valiosas.

Não posso deixar de falar, ainda, dos antigos colegas de trabalho do Gabinete 33, que em muito facilitaram minha vida nesse período. Agradeço a todos, em especial, à Eglayr Vasconcellos Paneque e ao desembargador Antonio Sydnei de Oliveira Júnior, cujo trabalho inspira aqueles que, como eu, tiveram o privilégio de fazer parte de sua equipe.

Aos "remanescentes" amigos das Arcadas, Danilo Tadeu Szigmond Franco e Juliana de Souza Santos, obrigada por ainda fazerem parte da minha vida, pelas discussões jurídicas e pelas eternas risadas.

Ao Ricardo, minhas sinceras desculpas pelo tempo que deveria ter sido seu e que não foi. Está aqui o resultado. 


\section{RESUMO}

O presente trabalho aborda a relação entre a culpabilidade e a responsabilidade penal das pessoas jurídicas. A pesquisa tem como objetivo principal analisar as construções teóricas que pretendem responder - ainda que criticamente - aos problemas existentes na mencionada relação, desenvolvendo (ou rejeitando) um conceito de culpabilidade (ou equivalente) da pessoa jurídica, bem como identificar meios de limitação desse modelo de responsabilidade.

Para tanto, o trabalho ressalta o debate havido, na admissão da responsabilidade penal da pessoa jurídica, entre política criminal e dogmática, enfatizando a necessidade de estratégias que transcendam o individualismo, fazendo uma breve descrição da culpabilidade individual e destacando os modelos de responsabilidade das pessoas jurídicas, bem como a relação entre ação e culpabilidade.

Por fim, será essencial compreender o conceito de "programas de compliance" e os efeitos de sua adoção nos mais variados sistemas legais existentes, para, com isso, definir critérios mínimos para uma racional aplicação dessa responsabilidade.

Palavras-chave: Culpabilidade - Pessoa Jurídica - Responsabilidade Penal - Política Criminal - Programas de Compliance - Autorregulação. 


\section{ABSTRACT}

The presente work discusses the relation between culpability and criminal responsability of corporations. The research has as its main goal to analyze the theorical constructions that intend to give answers - even criticals - to the problems existent in the mentioned relation, developing (or denying) a concept of corporation's culpability (or equivalent), and identify limits to this model of responsibility.

In order to do so, the work brings out the debate between criminal policy and dogmatic that exists in the admission of corporation's criminal responsibility, emphasizing the need for strategies that transcend individualism, doing a brief description of individual culpability and pointing out the models of corporation responsibility, as well the relation between action and culpability.

Finally, it will be paramount to understand the concept of "compliance programs" and the effects of its adoption in legal systems throughout the world, to define minimum requiriments for a rational application of this responsibility.

Key-words: Culpability - Corporation - Criminal Responsibility - Criminal Policy Compliance Programs - Self-regulation. 


\section{SUMÁRIO}

1. EXPOSIÇÃO DO PROBLEMA

1.1. A responsabilidade penal das pessoas jurídicas: um embate entre política-criminal e dogmática 11

1.2. Definições terminológicas: a "pessoa jurídica". 13

1.3. O embate entre política criminal e dogmática no breve histórico da responsabilidade penal dos entre coletivos

1.4. Objeções dogmáticas à responsabilidade penal da pessoa jurídica ............................ 23

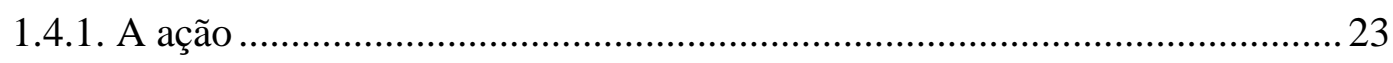

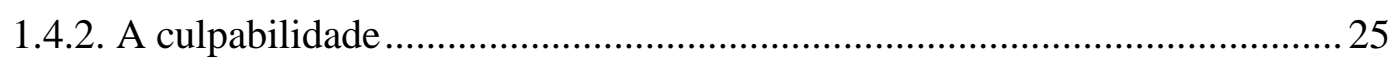



1.5. Questões político-criminais e dogmáticas favoráveis à responsabilidade penal da pessoa jurídica

1.5.1. O protagonismo das empresas nas relações sociais e em novas formas de criminalidade

1.5.2. A estrutura empresarial como facilitadora de crimes 32

1.5.3. A autorregulação como estratégia do Estado em face do aumento do poder empresarial.

1.5.4. As deficiências dogmáticas presentes na responsabilização individual por delitos praticados na estrutura empresarial e a admissão da responsabilidade penal da pessoa jurídica como expressão de proteção da pessoa humana

1.6. A culpabilidade como problema central na responsabilidade penal da pessoa jurídica.

\section{O TRATAMENTO JURÍDICA DA RESPONSABILIDADE DA PESSOA}

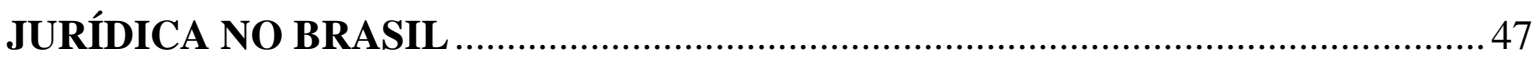

2.1. A responsabilidade penal da pessoa jurídica no Brasil

2.1.1. A Constituição Federal de 1998 e os conflitos interpretativos em relação à responsabilidade penal da pessoa jurídica 47

2.1.2. A Lei 9.605/98 e a responsabilidade penal da pessoa jurídica ....................50

2.1.3. O modelo de responsabilidade penal adotado ......................................... 51

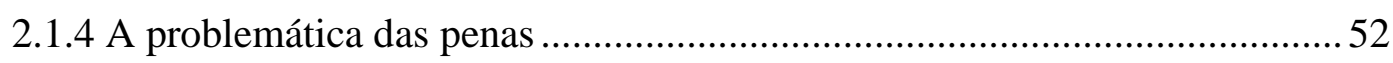

2.2. A Lei 12.846/2013 e a responsabilização administrativa e civil de pessoas jurídicas pela prática de atos contra a administração pública 


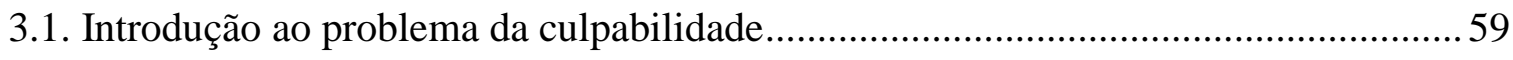

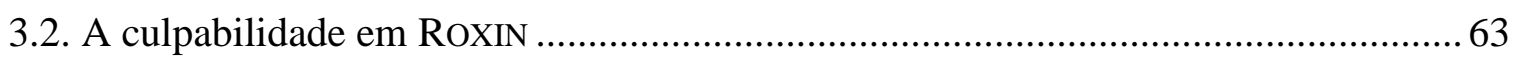

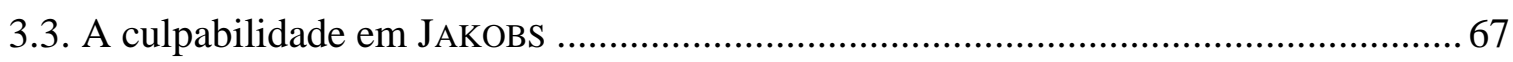

3.4. A busca por um conceito material de culpabilidade................................................ 71

3.4.1. A culpabilidade como "poder atuar de outro modo" (teoria social da

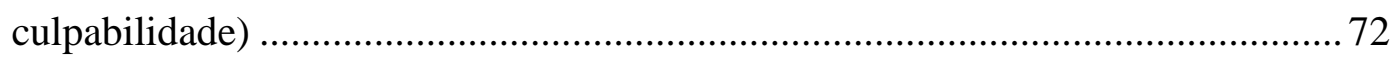

3.4.2. A culpabilidade como atitude interna juridicamente desaprovada ............. 74

3.4.3. A culpabilidade como decisão consciente da vontade pelo ilícito ............... 75

3.4.4. A culpabilidade como capacidade de motivação pela norma ...................... 76

3.4.5. A culpabilidade como dever responder pelo caráter próprio ....................... 78

3.4.6. A culpabilidade como quebra de fidelidade ao Direito .............................. 81

3.4.7. A culpabilidade como atuação injusta em face de uma norma exequível ... 82

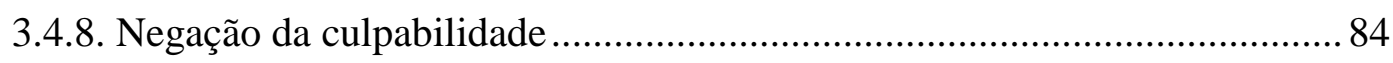

3.5. Aproximações entre a "culpabilidade individual" e uma possível "culpabilidade do

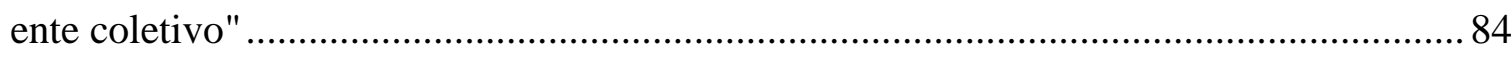

\section{MODELOS DE RESPONSABILIDADE DA PESSOA JURÍDICA E A}

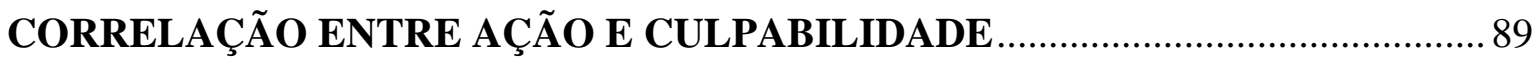

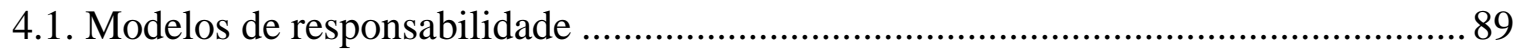

4.1.1. Modelo de responsabilidade indireta ..................................................... 90

4.1.2. Modelo de responsabilidade direta ......................................................... 97

4.2. Algumas considerações sobre os modelos de responsabilização ............................... 99

4.3. O objeto da culpabilidade e a possibilidade de conjugação de modelos teóricos

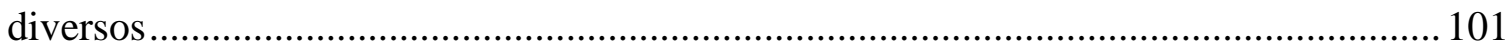

\section{A CULPABILIDADE E A RESPONSABILIDADE PENAL DA PESSOA}

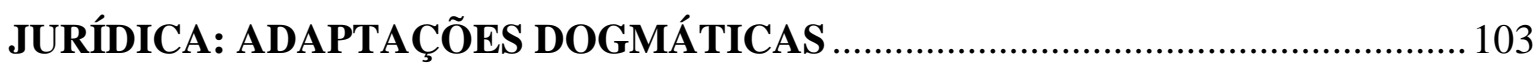

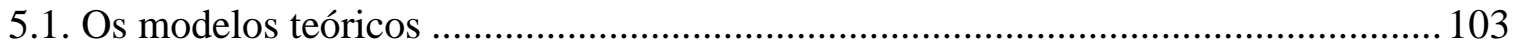

5.1.1. Traslado da culpabilidade da pessoa física para a pessoa jurídica ............ 103

5.1.2. A imposição de pena à pessoa jurídica sem culpabilidade: o estado de necessidade do bem jurídico de SCHÜNEMANN ................................................ 106

5.1.3. A culpabilidade pela consciência especial da pessoa jurídica de HAFTER 108

5.1.4. A culpabilidade pelo espírito normativo da pessoa jurídica de BUSCH ..... 109

5.1.5. A culpabilidade pela organização própria de TIEDEMANN ........................ 110 
5.1.6. A culpabilidade funcional do órgão de SCHROTH........................................ 116

5.1.7. A culpabilidade corporativa e a evitabilidade de HIRSCH ........................ 117

5.1.8. A culpabilidade pela condução empresarial de HEINE .............................. 120

5.1.9. A culpabilidade pelo caráter da empresa de LAMPE ................................ 125

5.1.10. A culpabilidade pela reprovabilidade ético-social de DANNECKER......... 129

5.1.11. A culpabilidade fundada no comportamento pós-delitivo (reactive fault) de

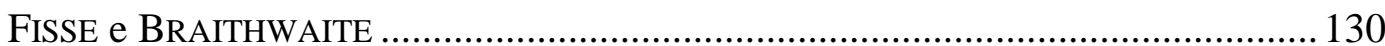

5.1.12. A responsabilidade penal da pessoa jurídica em JAKOBS: mudanças de posicionamento e contributo para uma culpabilidade empresarial

5.1.13. O conceito construtivista de CARLOS GóMEZ-JARA DíEZ: a culpabilidade da pessoa jurídica por sua cultura empresarial de descumprimento da legalidade ...

5.1.14. A busca de um modelo próprio de culpabilidade empresarial de ADAN NIETO MARTín

5.2. Alguns posicionamentos críticos à culpabilidade da pessoa jurídica e suas ponderações sobre o defeito de organização

5.3. Conclusões preliminares sobre as construções teóricas de culpabilidade empresarial, conceitos equivalentes e suas críticas

\section{COMPLIANCE E SUA POSSÍVEL RELAÇÃO COM A CULPABILIDADE}

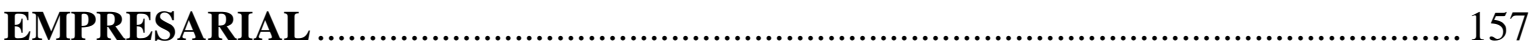

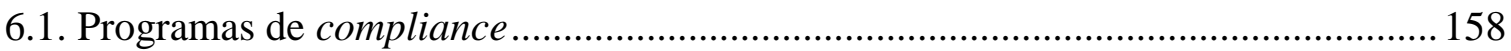

6.2. Estados Unidos e as Sentencing Guidelines ......................................................... 163

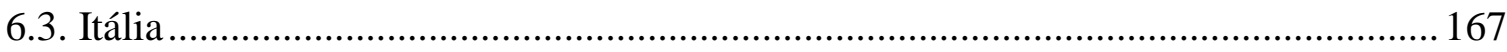

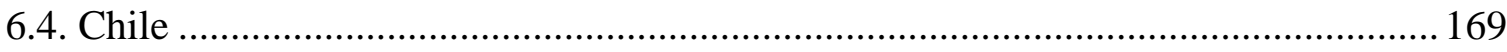

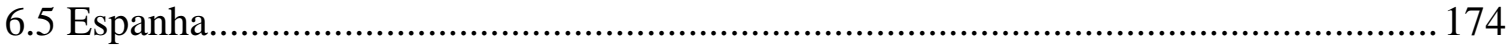

6.6. Os programas de compliance e a responsabilidade da pessoa jurídica no Brasil..... 179

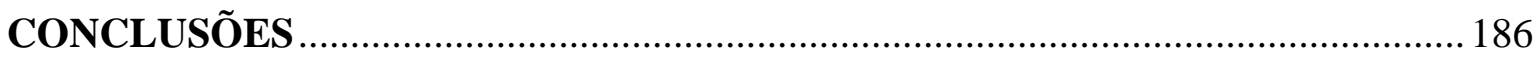

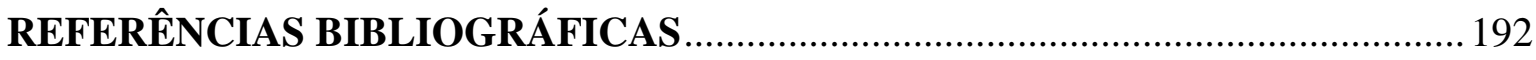




\section{EXPOSIÇÃO DO PROBLEMA}

\subsection{A responsabilidade penal das pessoas jurídicas: um embate entre política criminal e dogmática?}

O tema da responsabilidade penal da pessoa jurídica não é inédito na história. Vem, contudo, sendo constantemente abordado nos mais recentes trabalhos doutrinários por se revelar como um campo de conflito entre dois aspectos essenciais para a construção da Ciência do Direito Penal: a dogmática e a política criminal.

Nesse sentido, a dogmática penal tem se mostrado refratária às modificações no plano da sujeição ativa que a admissão dessa forma de responsabilização coloca ${ }^{1}$, justificando tal posicionamento na própria essência da pessoa jurídica, que a tornaria incompatível com os juízos reflexivos que a imposição de uma sanção penal demanda, todos eles voltados para a psique do agente.

Em sentido oposto, contudo, seus defensores vêm se debatendo por sua admissão, asseverando que a realidade tem exigido essa modificação e, manter-se alheia a ela seria transformar o Direito Penal em letra morta ${ }^{2}$. Assim, sendo necessária a responsabilidade penal da pessoa jurídica, o problema estaria um passo além, ou seja, em como fundamentá-la teoricamente ${ }^{3}$.

Os debates doutrinários, contudo, parecem não constituir óbice suficiente para

\footnotetext{
${ }^{1}$ Sobre isso, afirma LAMPE: “¿Por qué la dogmática penal há evitado hasta ahora desarrollar una teoría del injusto del sistema? Probablemente, la principal causa há sido que la dogmática - así como su acompañante, la criminología - hasta la fecha han partido, exclusivamente, de un puñado de autores individuales y se han centrando primariamente en las estructuras del injusto del indivíduo y no del sistema. Pese a que la dogmática no se le há escapado el hecho de que un autor puede agruparse com outros formando un sistema organizados de manera más o menos estricta, de ahí no há extraído la consecuencia de que el autor pierda parte de su responsabilidad en detrimento del sistema social, ni que le corresponda un incremento en su cuota de responsabilidad debido al sistema.”. LAMPE, Ernst-Joachim. La dogmática jurídico-penal entre la ontología social y el funcionalismo. Trad. Carlos Gómez-Jara Díez; Guillermo Orce e Miguel Polaino Orts. Lima: Grijley, 2003, p. 98.

${ }^{2}$ Como assevera FEIJOO SÁNCHEZ, analizando a reforma trazida pela LO 5/2010 ao Código Penal español, que albergou a responsabilidade penal da pessoa jurídica: "La reforma en este punto nos demuestra que el ordenamiento penal no es ni puede ser inmune a la evolución de las sociedades y que dicha evolución no sólo determina una expansión de la parte especial del Derecho Penal. La radical transformación del Derecho Penal vigente a través del art.31 bis obedece a factores complejos que se interrelacionan entre sí cuya influencia exacta resulta difícil de determinar.”. FEIJOO SÁNCHEZ, Bernardo José. La persona jurídica como sujeto de imputación jurídico penal. In: BAJO FERNÁNDEZ, Miguel. et al. Tratado de responsabilidad penal de las personas jurídicas. Pamplona: Civitas, 2012 p. 50.

${ }^{3}$ Como afirma BACIGALUPO, "Si la responsabilidade penal de la persona jurídica es necesaria, o problema teórico será la posibilidad de fundamentarla.". BACIGALUPO ZAPATER, Enrique. "Compliance" y derecho penal: prevención de la responsabilidade de directivos y de empresas. Buenos Aires: Hammurabi, 2012, p. 102.
} 
que o legislador admita a responsabilização da pessoa jurídica, quando se observa que diversos países, por grande influência, é bem verdade, das normativas internacionais, vêm admitindo alguma forma de responsabilização de tais entes, encaminhando-se, em especial, à tão temida responsabilidade penal. E, diga-se, temida, justamente porque, ao encarar um sujeito completamente diverso daquele para o qual a teoria do crime foi construída, não se encontra solução hábil para adequar o "modelo"4 já existente de responsabilidade penal.

Nesse contexto, deflagra-se como objeto central das recentes preocupações doutrinárias em relação à responsabilidade penal da pessoa jurídica a tentativa de sua compatibilização com a culpabilidade. O enfrentamento da questão da responsabilidade penal da pessoa jurídica desde o primado da culpabilidade é interessante por consistir campo de amplo debate e mínimo consenso (para não se dizer nenhum) mesmo entre os defensores dessa forma de responsabilização. De outro lado, a culpabilidade é expressão máxima, na teoria do delito, da valoração do subjetivo, subjetividade esta que, em princípio, parece incompatível com a pessoa jurídica.

Nesse debate, contudo, não se pode descurar da função limitadora do exercício punitivo estatal que a culpabilidade pode (e deve, pensa-se) exercer e que, se anulado, converte qualquer modalidade de responsabilização em objetiva.

A preocupação do presente trabalho será, então, delinear o estado da questão. Entender como a relação entre a culpabilidade e a responsabilidade da pessoa jurídica vem sendo tratada na doutrina e nas legislações, verificando pontos comuns que nos permitam observar um conteúdo mínimo de que a responsabilização da pessoa jurídica (e, saliente-se, não só responsabilização penal) não possa se desapegar, tendo-se em conta, para tanto, a função limitadora do exercício punitivo que o conceito de culpabilidade (ou que seu equivalente, dependendo da formulação teórica) deve realizar.

Perceba-se, portanto, que a preocupação da pesquisa não é apenas teórica, mas também prática. Afinal, a existência de leis prevendo a responsabilização, inclusive penal, da pessoa jurídica (e a tendência internacional de previsão cada vez mais abrangente de tal responsabilização) não permite que um estudo comprometido possa se fazer alheio à necessidade de delinear critérios mínimos para que esta responsabilização se realize de forma racional e limitada.

Nesse aspecto, será de suma importância analisar o tema dos programas de

\footnotetext{
${ }^{4}$ Usou-se a expressão "modelo" entre aspas por crer-se não haver real uniformidade na aplicação do Direito Penal, mesmo em relação ao sujeito pessoa física. Teremos oportunidade de vislumbrar essa falta de uniformidade ao tratar da própria culpabilidade individual (capítulo 3).
} 
compliance, revelando como a dimensão organizativa da pessoa jurídica pode ter influência sobre a sua responsabilização e servir de critério orientativo para o dimensionamento dessa responsabilidade.

Pensa-se, assim, que o embate entre política criminal e dogmática que o tema da responsabilidade penal da pessoa jurídica encerra, em especial sob o enfoque da culpabilidade, e pelo qual o presente trabalho irá trafegar, deve render frutos práticos, que, sem revelar o fim do debate, podem (e devem) constituir critérios mínimos no tratamento desta e mesmo de outras modalidades de responsabilização.

\subsection{Definições terminológicas: a "pessoa jurídica"}

Antes mesmo de adentrarmos na discussão acima pontuada, parece-nos importante trazer a baila algumas considerações terminológicas a respeito do emprego da locução "pessoa jurídica" e de seus equivalentes conceituais pela doutrina (em especial, brasileira), observando-se o reflexo da adoção de certas nomenclaturas sobre a extensão da responsabilidade. Nessa medida, a discussão que se pretende preliminarmente travar, reflete a busca por uma acuidade terminológica (ou por uma maior amplitude no emprego dos termos), não se traduzindo em mero preciosismo linguístico.

Ao tratar da questão da responsabilidade penal das "pessoas jurídicas", percebe-se não haver uma uniformidade no emprego de tal denominação pela doutrina. Uma leitura, mesmo que superficial, pelos textos brasileiros sobre o tema, revela a utilização de nomenclaturas diversas, tais como responsabilidade penal das empresas ${ }^{5}$, dos entes coletivos $^{6}$, das coletividades ${ }^{7}$, além da pessoa jurídica ${ }^{8}$, termo esse de emprego mais comum, até por influência da previsão constitucional brasileira (artigos 173, § $5^{\circ}$ e 225 , §

\footnotetext{
${ }^{5}$ SHECAIRA, Sérgio Salomão. Responsabilidade penal da pessoa jurídica. Rio de Janeiro: Elsevier, 2011, p. 13; RIOS, Rodrigo Sanchez. Indagações sobre a possibilidade da imputação penal à pessoa jurídica no âmbito dos delitos econômico. In: PRADO, Luiz Regis; DOTTI, René Ariel (coord.). Responsabilidade penal da pessoa jurídica: Em defesa do princípio da imputação subjetiva. 2.ed. São Paulo: Revista dos Tribunais, 2010, p.197.

${ }^{6}$ SHECAIRA, Sérgio Salomão. Responsabilidade penal..., p. 21.

${ }^{7}$ Id. Ibid., p. 134.

${ }^{8}$ Pode-se citar, dentre vários autores LUISI, Luiz. Notas sobre a responsabilidade penal das pessoas jurídicas. In: PRADO, Luiz Regis; DOTTI, René Ariel (coord.). op.cit., p.27-42; PRADO, Luiz Regis. Responsabilidade penal da pessoa jurídica: fundamentos e implicações. In: PRADO, Luiz Regis; DOTTI, René Ariel (coord.). op.cit., p. 125-154 ; DOTTI, René Ariel. A incapacidade criminal da pessoa jurídica (Uma perspectiva do direito brasileiro). In: PRADO, Luiz Regis; DOTTI, René Ariel (coord.). op.cit., p. 157194;

${ }^{9}$ Artigo 173, § 5º da Constituição Federal de 1988: “A lei, sem prejuízo da responsabilidade individual dos dirigentes da pessoa jurídica, estabelecerá a responsabilidade desta, sujeitando-a as punições compatíveis
} 
$3^{\mathrm{o} 10}$ ) e do conteúdo da Lei $9.605 / 98$ que trouxe, em seu artigo $3^{\mathrm{o} 11}$, a previsão legal da responsabilidade penal da pessoa jurídica nos crimes ambientais.

Entre os civilistas, essa não unanimidade na denominação da "pessoa jurídica" é também apontada. O nosso Código Civil e também o respectivo Código alemão empregam tal termo, tido como vantajoso por realçar o aspecto jurídico da construção ${ }^{12}$. Em Portugal, utiliza-se a nomenclatura "pessoa coletiva", ressaltando a forma de composição do ente e, com isso, olvidando das "instituições" cuja constituição é originada de uma destinação patrimonial (como as fundações), e não do intuito de reunião de pessoas para um certo fim comum. Já na França, fala-se em "pessoas morais"13.

Empregar-se o termo "empresas", de outro lado, significa, tecnicamente, restringir a sujeição ativa a uma classificação derivada do Direito Empresarial e advinda de um conceito econômico, limitando-a à atividade exercida pelo empresário (exercício profissional de atividade econômica organizada para a produção ou a circulação de bens ou de serviços) e submetida à disciplina juscomercialista ${ }^{14}$, devendo-se consignar que, a despeito do desenvolvimento doutrinário de uma teoria da empresa, não se superou a classificação dicotômica que diferencia atividades econômicas submetidas ao regime civil (aquelas desenvolvidas sem a organização de empresa; profissionais intelectuais; empresários rurais não registrados na Junta Comercial; e cooperativas - consoante artigo 966, parágrafo único; artigo 971 e artigo 982, todos do Código Civil) e ao regime comercial $^{15}$. Com isso, restringir-se-ia o universo de discussão dessa modalidade de

\footnotetext{
com sua natureza, nos atos praticados contra a ordem econômica e financeira e contra a economia popular.".

${ }^{10}$ Artigo 225, § $3^{\circ}$, da Constituição Federal de 1988: “As condutas e as atividades consideradas lesivas ao meio ambiente sujeitarão os infratores, pessoas físicas ou jurídicas, a sanções penais e administrativas, independentemente da obrigação de reparar os danos causados.”.

${ }^{11}$ Assim dispõe o aludido articulado: "As pessoas jurídicas serão responsabilizadas administrativa, civil e penalmente conforme o disposto nesta lei, nos casos em que a infração seja cometida por decisão de seu representante legal ou contratual, ou de seu órgão colegiado, no interesse ou no benefício da sua entidade. Parágrafo único: a responsabilidade das pessoas jurídicas não exclui a das pessoas físicas, autoras, co-autoras ou partícipes do mesmo fato".

${ }^{12}$ Nesse sentido, PEREIRA, Caio Mário da Silva. Instituições de direito civil. v.1. Rio de Janeiro: Forense, 1978. v.1, p. 256; VENOSA, Silvio de Salvo. Direito Civil. v.1.3.ed. São Paulo: Atlas, 2002, p. 252.

${ }^{13}$ Nesse sentido, afirma SílVIO DE SALVO VENOSA: "Não é unânime na doutrina e nas várias legislações a denominação pessoa jurídica. Essa é a denominação de nosso Código e também do Código alemão. Na França, usa-se da expressão "pessoas morais". Na verdade, a denominação por nós utilizada tem a vantagem de realçar o aspecto jurídico, o que nos interessa. "Pessoa coletiva" é como denomina o Direito português, realçando mais o aspecto externo do instituto; enfatiza as pessoa jurídicas constituídas de indivíduos, mas deixa de fora aquelas pessoa jurídicas constituídas fundamentalmente de patrimônio, que são as fundações.". op. cit, p. 252.

${ }^{14}$ Sobre isso, ver: REQUIÃO, Rubens. Curso de direito comercial. v.1. São Paulo: Saraiva, 2003, p. 59 e ss.

${ }^{15}$ Afirma FABIO ULHÔA COELHO: "A teoria da empresa não acarreta a superação da bipartição do direito privado, que o legado jurídico de Napoleão tornou clássica nos países de tradição romana. Altera o critério de delimitação do objeto do Direito Comercial - que deixa de ser os atos de comércio e passa a ser a empresarialidade -, mas não suprime a dicotomia entre o regime jurídico civil e comercial. Assim, de acordo
} 
responsabilidade penal a uma específica forma de sociedade que constitui modalidade de pessoa jurídica.

Deve-se ter em mente, ainda, que a própria denominação "pessoa jurídica”, em sua literalidade, por exigir, para a sua existência legal, a "inscrição do ato constitutivo no respectivo registro, precedida, quando necessário, de autorização ou aprovação do Poder Executivo" (artigo 45, caput, do Código Civil), exclui, desde logo, certos grupos de personificação anômala ${ }^{16}$, dentre os quais parecem de grande interesse as sociedades em comum, porquanto apenas lhes faltariam a formalidade ou regularidade do registro para converterem-se em pessoa jurídica, conquanto por sua atividade real em muito se aproximariam de tais entes.

Sabe-se que o emprego da nomenclatura "responsabilidade penal da 'pessoa jurídica'”, tão corrente na doutrina penal brasileira sobre o tema, deriva da própria opção do legislador de utilizar tal locução nos dispositivos constitucionais (quais sejam, os artigos $173, \S 5^{\circ}$ e $225, \S 3^{\circ}$ ) que deram ensejo ao debate sobre a possibilidade de responsabilização criminal desses entes. Conquanto seja assim, deve-se consignar, desde logo, que o termo, para os fins e efeitos de se delinear a sujeição ativa na responsabilidade penal, não pode ser tomado pela sua concepção civilista estrita e formal, no sentido de que só será pessoa jurídica aquela submetida ao regular registro. Pelo contrário, deve englobar, também, a "pessoa jurídica irregular", aquela que, apesar de não poder constituir essa personalidade pela ausência de requisito legal, figura, na realidade, em determinadas relações jurídicas (como as sociedades sem registro, ou com registro irregular, ou sem autorização de funcionamento), sujeitando-se a um tratamento específico pelo Direito Civil que as qualifica e as regula como "sociedades em comum". Como a indagação dessa forma de responsabilização penal tem amparo, essencialmente, em demandas advindas da realidade, não se pode, por um corte terminológico, deixar ao largo entes com atuação fundamental na sociedade e, portanto, para os quais deve se voltar também as discussões relacionadas à responsabilidade penal, pelo menos não no presente trabalho, cujo objetivo é tratar num espectro mais amplo eventual concepção de culpabilidade na responsabilidade penal desses entes, sem, desde logo, fazer restrições sobre limites na incidência dessa responsabilidade, ainda que afetos a certos aspectos da própria culpabilidade, como a

com o Código Civil de 2002, continuam excluídas da disciplina juscomercialista algumas atividades econômicas. São atividades civis, cujos exercentes não podem, por exemplo, requerer a recuperação judicial, nem falir”. COELHO, Fabio Ulhôa. Manual de Direito Comercial. 22.ed. São Paulo: Saraiva, 2010, p. 15.

${ }^{16}$ Cf. VENOSA, Silvio de Salvo. Direito civil..., p. 265. 
imputação.

Observe-se, de outro lado, que a própria doutrina estrangeira parece não estar alheia a tais considerações terminológicas a respeito da amplitude da possibilidade de sujeição ativa. JORGE DOS REIS BRAVOS, ao se referir às categorias dogmáticas e sua construção voltada para a imputabilidade de indivíduos afirma que é pertinente a questão de saber se tais categorias são transponíveis, ou não, ao "plano das pessoas coletivas e mais aprofundadamente ainda -, a entes coletivos desprovidos de personalidade jurídica, embora relevantes para o direito, quanto a determinados vínculos e relações jurídicas"17. De igual modo, KLAUS TIEDEMANN, reconhece o caráter restritivo de se falar numa responsabilidade das "pessoas jurídicas", e não das empresas ${ }^{18}$. Por outro lado, BERNARDO FEIJÓo SÁNCHEZ salienta como um dos problemas a ser enfrentado na responsabilidade penal da pessoa jurídica a determinação de quais pessoas jurídicas podem ser feitas responsáveis criminalmente, consignando que, nessa identificação, deve-se ponderar o papel das "sociedades em fase de constituição, das sociedades de fato e das sociedades irregulares", o que só pode ser concretamente alcançado tendo-se em conta os "tipos de pessoas jurídicas reconhecidas em cada ordenamento nacional pelo Direito Civil, Direito Mercantil ou Direito Público", bem como os "requisitos para o reconhecimento da personalidade jurídica" ${ }^{, 19}$.

Diante de tais dificuldades, poder-se-ia argumentar que caberia ao Direito Penal se valer, nesse específico âmbito, do raciocínio da doutrina civilista ${ }^{20}$, no sentido de que apenas a aquisição de direitos dependerá da observância dos requisitos formais estabelecidos pela norma (ou seja, da caracterização formal da personalidade jurídica), mas

\footnotetext{
${ }^{17}$ BRAVO, Jorge dos Reis. Direito Penal de Entes Colectivos: Ensaio sobre a punibilidade de pessoas colectivas e entidades equiparadas. Coimbra: Coimbra Editores, 2008, p. 27.

${ }^{18}$ Isso se conclui da leitura do seguinte trecho "Por lo demás, a nivel de la Unión Europea misma, la responsabilidad cuasi-penal de las empresas (no solamente de las "personas jurídicas") está siendo considerada como modelo legislativo y jurisprudencial en mucho Estados-Miembros". TIEDEMANN, Klaus. Nuevas tendencias en la responsabilidad penal de personas jurídicas. In: Dogmática penal del tercer milênio: Libro homenaje a los professores Eugenio Raúl Zaffaroni y Klaus Tiedemann. Lima: Ara, 2008, p. 400.

${ }^{19}$ Ressalta FEIJÓO SÁNCHEZ: "Una mayor concreción no es posible aquí ya que esta cuestión depende de los diferentes tipos de personas jurídicas reconocidas en cada ordenamiento nacional por el Derecho civil, el Derecho mercantil o el Derecho público y los requisitos para el reconocimiento de personalidad jurídica. Sólo cabe destacar en este momento la importância de un estudo detallado en este sentido". FEIJÓO SÁNCHEZ, Bernardo. Cuestiones básicas sobre la responsabilidad penal de las personas jurídicas, de otras personas morales y de agrupaciones y asociaciones de personas. In: FRANCO, Alberto Silva; NUCCI, Guilherme de Souza (org.). Doutrinas Essenciais: Direito Penal. v. 3, Parte Geral 2. São Paulo: Revista dos Tribunais, 2010, p. 111.

${ }^{20}$ Nesse sentido, aliás, FEIJóo SÁNCHEZ observou, analisando o artigo 31 bis do Código Penal espanhol, que a ausencia de definição em tal Código do que se entende por pessoa jurídica, acaba levando à conclusao de que se deve buscar outros ramos do ordenamento jurídico para determinar seu conteúdo, abrindo as portas para casuística nessa definição. FEIJÓO SÁNCHEZ, Bernardo José. La persona jurídica como sujeto de imputación jurídico penal. In: BAJO FERNÁNDEZ, Miguel. et al. op.cit., p. 55.
} 
a imposição de deveres existirá de qualquer modo ${ }^{21}$. O grande problema, contudo, seria não ultrapassar, com uma interpretação extensiva, os limites do princípio da legalidade (cf. artigo $5^{\circ}$, inciso XXXIX, da Constituição Federal e artigo $1^{\circ}$ do Código Penal), o que, todavia, não nos parece ocorrer. Afinal, deve-se ter em mente que a "personalidade jurídica penal" não deve se confundir com a "personalidade jurídica civil", posto que o reconhecimento da responsabilidade criminal desses "agentes coletivos" é (ou está sendo) resultado de uma demanda de política criminal de reconhecimento do papel relevante dos "entes coletivos" (independentemente da sua personificação jurídica nos termos da doutrina civil) nas novas modalidades de criminalidade. Assim, o critério de "capacidade ativa" (de praticar crimes) do Direito Penal não pode se submeter ao formalismo da caracterização da personalidade jurídica do Direito Civil, uma vez que, assim, estar-se-ia afastando essa nova modalidade de responsabilidade penal de seus argumentos fundacionais, quais sejam, das necessidades de realidade constatadas pela política criminal e que ensejaram a busca pela adaptação da dogmática ${ }^{22}$.

Em termos gerais, tais considerações iniciais permitem abrir espaço para o emprego, no presente trabalho, de termos diversos de "pessoa jurídica"23 para se designar essa modalidade de responsabilidade penal que aqui se pretende analisar no específico âmbito da culpabilidade. Deve-se ter em conta que o objetivo da presente tese não é tratar dos elementos da culpabilidade em suas especificidades aplicados à pessoa jurídica, mas tentar traçar os delineamentos teóricos que vem sendo trazidos para definir um conteúdo material para a culpabilidade. Bem por isso, importa essa acuidade linguística na utilização dos termos não para, desde logo, vincular-se a certa forma de pensamento com a determinação de aspectos como, por exemplo, a imputabilidade, mas para conceder certa coerência no emprego dos vocábulos durante nossas explanações.

\footnotetext{
${ }^{21}$ Assim afirma CAIO MÁRIo DA SILVA PEREIRA: “A compreensão do tratamento que a lei dispensa à sociedade irregular somente pode decorrer daquele princípio, segundo o qual a aquisição de direitos é consequência da observância da norma, enquanto a imposição de deveres (princípio da responsabilidade) existe sempre". PEREIRA, Caio Mário da Silva. op. cit., p. 299.

${ }^{22}$ Nesse sentido, concordamos com FEIJOO SÁNCHEZ, quando assevera que "[...] hubiera sido preferible un sistema que - atendiendo a la imprescindible seguridad jurídica que es preciso siempre exigir en el ámbito del ordenamiento jurídico - se fijara más en la complejidad de la organización que en el dato formal de la personalidad jurídica, de tal manera que se pudiera detectar realmente una dinámica propia diferente a la de sus miembros (lo que podría representar una especie de 'personalidad propia' en sentido jurídico-penal).". FEIJÓO SÁNCHEZ, Bernardo José. La persona jurídica como sujeto de imputación jurídico penal. In: BAJO FERNÁNDEZ, Miguel. et al. op.cit, p. 56.

${ }^{23}$ Empregaremos, então, termos como "empresa" ou "ente coletivo", além de "pessoa jurídica", sem que com isso se pretenda demonstrar a adoção de qualquer posicionamento sobre os sujeitos a que se deve destinar a responsabilidade penal.
} 


\subsection{O embate entre política criminal e dogmática no breve histórico da responsabilidade penal dos entes coletivos}

Um breve traçado do histórico evolutivo da responsabilidade dos entes coletivos possibilita descortinar a influência que a ponderação da importância social desses entes em cada específica época exerceu sobre a admissão de sua responsabilização. A bem da verdade, essa digressão histórica permite, desde logo, apontar a colidência entre argumentos político-criminais e dogmáticos, mesmo antes da existência de tais critérios classificatórios.

A discussão acerca da responsabilização criminal do ente coletivo não é atual. Em verdade, foram atualizados os argumentos trazidos à baila para se retomar uma forma de responsabilização que não é inédita na história do pensamento e da práxis jurídica, mas que se vê inovada na medida em que se pretende, no presente, enfocá-la sob um ângulo crítico, submetendo-a as limitações dogmáticas construídas no âmbito do Direito Penal como garantia de seu exercício, em tese, mais racionalizado.

Perceba-se que, antes do século XVIII, podia se falar, em regra, numa aceitação da responsabilização do ente coletivo com a aplicação de sanções coletivas ${ }^{24}$. Interessante observar, aliás, que no Direito Canônico (que contribuiu, em certa medida, para o dimensionamento da personalidade jurídica ao distinguir o ente coletivo, no caso, a Igreja, identificada com Deus, dos seus componentes), conquanto tenha havido, neste período, divergências interpretativas sobre a admissão de responsabilidade criminal dos entes coletivos, prevaleceu a admissão da utilização de medidas punitivas, isto pelo objetivo de se controlar a Igreja em face de seu poderio exacerbado ${ }^{25}$.

\footnotetext{
${ }^{24}$ Como exemplo, cita-se o Direito babilônico (que no Código de Hammurabi previu a responsabilização da cidade perante a vítima pela prática de certos delitos), o Direito grego (em relação ao qual, pode-se exemplificar com a punição corporativa das organizações coletivas - thiasos - de cunho social ou religioso por seus delitos), e mesmo o Direito Romano. Em relação a esse último, há certas divergências interpretativas. A "personalidade coletiva" só foi reconhecida no Direito Romano na época imperial, com o entendimento de que os direitos e obrigações das universitas eram distintos daqueles de seus componentes. Compreendia-se, entretanto, que este ente, por possuir um caráter ficcional, não podia ser responsabilizado autonomamente. Conquanto fosse assim, não se pode descurar que interpretações em sentido contrário existiram, como a de MESTRE e VALEUR, autores para os quais o Direito Romano trouxe algumas previsões de responsabilidade criminal de entes coletivos. Assim, também, entenderam, em geral, os glosadores, criticados por terem se apegado à literalidade dos textos analisados. Sobre o tema, ver: CASTRO E SOUSA, João. As pessoas colectivas em face do direito criminal e do chamado "direito de mera ordenação social". Coimbra: Coimbra Editores, 1985, p. 25. FRANCO, Affonso Arinos de Mello. Responsabilidade criminal das pessôas jurídicas. Rio de Janeiro: Gráphica Ypiranga, 1930.p. 33. SHECAIRA, Sérgio Salomão. Responsabilidade penal..., p. 2-3.

${ }^{25}$ CASTRO E SOUSA, João. op. cit. p. 33. Interessante, também, fazer menção ao Direito Francês anterior à Revolução, que, por influência de criminalistas italianos a partir do século XVI, disciplinou procedimento
} 
Em linhas gerais, pode-se dizer que, até o século XVIII, houve uma ampla aceitação da responsabilidade penal dos entes coletivos, ainda que sem uma definição precisa sobre a natureza dessa coletividade, e com a existência de alguns posicionamentos em sentido contrário. Entretanto, é perceptível que a admissão dessa modalidade de responsabilização consagrou-se, sobretudo, por necessidades práticas, a exemplo da tentativa de se refrear o poderio das corporações religiosas no bojo do Direito Canônico. A história nos mostra, então, que as necessidades práticas fazem sucumbir os argumentos dogmáticos em sentido contrário. E, por isso mesmo, uma mudança de necessidades se reflete numa mudança de sentido jurídico sobre aquilo que é aceitável ou não. É assim que perceberemos uma alteração de rumo após a Revolução Francesa e com a consequente consagração do individualismo.

O surgimento de uma nova ideologia, fundada no liberalismo, deixou em segundo plano as corporações, dando ênfase ao individualismo. Muito mais, no entanto, que uma mudança de ideologia que vem a negar a prática corporativa, certo é que esses agrupamentos perderam seu poderio como coletividade, de forma que não se via mais a necessidade de seu controle pela utilização do instrumental penal.

A partir do início do século XIX, constata-se a supressão da responsabilidade penal das pessoas jurídicas dos $\operatorname{Códigos}^{26}$, reflexo mesmo da Revolução Francesa, que instituiu a fórmula de responsabilização penal individual ${ }^{27}$, consagrando-se o princípio "societas delinquere non potest".

Há controvérsias doutrinárias sobre o efetivo fundamento ideológico que ocasionou essa mudança de rumo. Para alguns, a influência da teoria da ficção de SAVIGNY, cuja construção se opõe à responsabilização do ente coletivo como um ente autônomo no sentido de sua vontade e ação, apontou para essa alteração conceitual em relação à possibilidade de ser a pessoa jurídica sujeito ativo de $\operatorname{crimes}^{28}$. Para outros, entretanto, as razões de tal modificação são de ordem política ${ }^{29}$.

criminal contra associações e comunidades (ou seja, entes coletivos) em um Estatuto de 1670, demonstrando, assim, a capacidade criminal dessas coletividades. Sobre isso, ver: SHECAIRA, Sérgio Salomão. Responsabilidade penal.... p. 13-14.

${ }^{26}$ ABOSO, Gustavo Eduardo; ABRALDES, Sandro Fabio. Responsabilidad de las personas jurídicas en el derecho penal comparado. Buenos Aires: Editorial B de F, 2000, p. 4.

${ }^{27}$ TIEDEMANN, Klaus. Nuevas tendências..., p. 400. Também: TIEDEMANN, Klaus. Responsabilidad penal de personas jurídicas y empresas en derecho comparado. In: FRANCO, Alberto Silva. NUCCI, Guilherme de Souza. Doutrinas Essenciais: Direito Penal. V. 3, Parte Geral 2. São Paulo: Revista dos Tribunais, 2010, p. 788; SHECAIRA, Sérgio Salomão. Responsabilidade penal..., p. 14.

${ }^{28}$ Sobre isso, ver SHECAIRA, Sérgio Salomão. Responsabilidade penal.... p. 88-90.

${ }^{29}$ Saliente-se que está leitura comparativa é feita por: SILVEIRA, Renato de Mello Jorge. Direito penal 
É nesse contexto que as objeções dogmáticas à responsabilidade penal dos entes coletivos surgem e influenciam, pelos séculos seguintes, toda a produção legislativa, em alguns casos até os dias de hoje, em especial nas legislações de "civil law". Afirma-se, por exemplo, que a teoria da pena, conjugada às discussões sobre a essência das pessoas jurídicas, determinaram o apoio ou não de alguns autores à responsabilidade penal desses entes coletivos. Assim, BERNER, BINDING e VON LILIENTHAL teriam se apoiado na teoria da ficção, entendendo que as pessoa jurídicas, sem uma existência desvinculada de seus componentes, não poderiam sofrer uma sanção penal de forma a ativar a função que a pena teria $^{30}$.

Deve-se ter em mente, também, que é nesse caldo cultural em que as principais teorias do delito (em especial aquelas voltadas à culpabilidade) vão se desenvolver ${ }^{31}$. Por isso mesmo, os elementos do delito e as formulações principiológicas que envolvem o campo do saber penal se fundaram na pessoa humana, ocasionando a incompatibilidade metodológica de tais conceitos com a pessoa jurídica e sua eventual responsabilização penal. Nesse sentido, as objeções que ainda remanescem na doutrina se fundam substancialmente nas construções teóricas advindas desse específico momento histórico.

É perceptível, contudo, uma grande transformação na realidade social (e, em consequência, na percepção da criminalidade), suscitando, no último terço do século XIX e no primeiro do século $\mathrm{XX}$, o questionamento da vigência desse brocardo latino entendido como princípio até então orientador do direito penal. ${ }^{32}$

Nos países de sistema de "common law", o reconhecimento da possibilidade de responsabilização penal das pessoa jurídicas se dá há mais de 150 anos (ainda que com

\footnotetext{
supra-individual: interesses difusos. São Paulo: Revista dos Tribunais, 2003, p. 193-194.

${ }^{30}$ Segundo GARCÍA CAVERO: "En efecto, para poder decidir si la pena despliega su función, hay que precisar cómo están constituidos los sujetos de Derecho Penal. Por ello, no sería inexato sostener que defensores de la irresponsabilidad penal de las personas jurídicas como Berner, Binding o von Lilienthal se apoyaron de alguna forma en la teoría de la ficción, mientras que autores como von Liszt, Hafter y Mestre afirmaron la posibilidad de una responsabilidad penal de las personas jurídicas a partir de sua realidad social. En cualquier caso, la posición doctrinal que finalmente se impuso en esta etapa de la historia de las ideias dogmáticas fue aquella que negaba la responsabilidad penal de los entes colectivos, sintetizándose su conclusión central en el extendido aforismo de societas delinquere non potest.". GARCÍA CAVERO, Percy. La persona jurídica como sujeto penalmente responsable. In: YACOBUCCI, Guillermo J. (dir.). Derecho penal empresário. Montevidéu: B. de F., 2010, p. 63-64.

${ }^{31}$ As indagações sobre a vontade do agente, por exemplo, surgem na metade do século XIX e vão determinar toda uma construção teórica da culpabilidade, afastando-se das ideias advindas do Direito Natural. Sobre isso, ver: CHAVES CAMARGO, Antonio Luis. Culpabilidade e reprovação penal. São Paulo: [S. n.], 1993, p. 118.

${ }^{32}$ BAJO FERNÁNDEZ, Miguel; BACIGALUPO, Silvina. Derecho penal económico. Madrid: Centro de Estudios Ramón Areces, 2001, p. 119.
} 
diferenças nos modelos de responsabilização adotados ${ }^{33}$. A responsabilidade penal das pessoas jurídicas no mundo anglo-saxão fora "reintroduzida", desde meados do século XIX, inicialmente para os delitos omissivos e imprudentes, evoluindo para abarcar as "public welfare offences", até alcançar uma previsão geral de tal responsabilidade, sobretudo vinculada à delinquência dos negócios ${ }^{34}$.

Nos sistemas de "civil law" (e que, portanto, nos interessa mais proximamente) o nascimento do Direito econômico ${ }^{35}$ moderno abrirá espaço para se excepcionar o dogma "societas delinquere non potest". Assim, na Europa continental, a partir dos anos 20, percebe-se tal direcionamento em relação à matérias tributárias, aduaneiras e de livre concorrência, tendência seguida pelo Japão nos anos $30^{36}$. Não se pode olvidar, contudo, que a retomada da questão da responsabilidade penal dos entes coletivos à época também se deveu ao surgimento de um "direito de ocupação" após a Segunda Guerra Mundial, na Europa, que implicou na influência da cultura jurídica de outros países em território alheio. Nesse sentido, constatou-se a influência da tradição jurídica anglo-saxã no restante do território europeu, em especial na Alemanha, em que os tribunais chegaram, na década de cinquenta, a impor sanções penais às pessoas jurídicas, utilizando-se, para tanto, de princípios derivados do direito anglo-saxônico ${ }^{37}$. É bem verdade que tal influência não chegou a determinar a consagração da responsabilidade penal da pessoa jurídica, pelo menos no território alemão, na medida em que se reafirmou a impossibilidade de albergo dessa modalidade de responsabilização, fundando-se,

\footnotetext{
${ }^{33}$ Afirma CELIA WELLS: “Common law jurisdictions have embraced corporate criminal liability for over 150 years but unsurprisingly there are differences in the approach each has taken. It can be said that in general the federal rules in United States and in Australia are much broadest while England has the narrowest.". WELLS, Celia. Corporations and Criminal Responsability. New York: Oxford, 2001, p. 127.

${ }^{34}$ TIEDEMANN, Klaus. Responsabilidad penal..., p. 787-806.

${ }^{35}$ Aqui, parece-nos importante definir a noção de "direito penal econômico". Esclarece RENATO DE MELLO JORGE SILVEIRA que o termo não é unívoco Pode tanto ser caracterizado pelos atores envolvidos no tipo de criminalidade (criminosos de "colarinho branco"), como também ser traduzido na regulação que objetiva proteger a própria ordem econômica, seja esta entendida em sentido amplo, sob a perspectiva da produção e circulação de bens e mercadorias, seja em sentido estrito, sob a ótica do controle estatal sobre a economia com vistas a garantir uma correta e adequada distribuição do bem-estar entre seus cidadãos. SILVEIRA, Renato de Mello Jorge. A ideia penal sobre a corrupção no Brasil: da seletividade pretérita à expansão de horizontes atual. Revista Brasileira de Ciências Criminais, v. 89, p. 418 e ss., 2011.

${ }^{36}$ TIEDEMANN, Klaus. Nuevas tendencias..., p. 401.

${ }^{37}$ Segundo GARCía CAVERo, este seria o segundo momento principal em que se coloca em debate a responsabilidade penal da pessoa jurídica. Afirma o autor que: "El segundo momento de replanteamiento de la cuestión de la responsabilidad penal de las personas jurídicas se dio a raíz del surgimiento de un Derecho de ocupación en Europa luego de la Segunda Guerra Mundial. En esta época, vários principios de la tradición jurídica anglosajona aterrizaron en Europa occidental y empezaron a ser recepcionados por los tribunales europeos.". Acrescenta, ainda, que: "En el terreno propiamente penal, se presentaron vários casos en la década de los cincuenta, en que los tribunales penales alemanes utilizaron principios de tradición anglosajona para castigar penalmente a las personas jurídicas por delitos cometidos a partir de sus actividades.". GARCÍA CAVERO, Percy. La persona jurídica..., p. 62-63.
} 
sobretudo, no argumento da incapacidade de ação do ente coletivo ${ }^{38}$. Todavia, não se pode olvidar que o discurso político criminal que percebeu a retomada do poderio das empresas e o protagonismo delas em novas formas de criminalidade $^{39}$ constituiu uma nova racionalidade que vem influenciando as normas de Direito Internacional e as legislações dos mais diversos países. Tanto é assim que reformas paulatinas foram se operando na Europa no sentido da responsabilização penal dos entes coletivos, podendo-se citar Holanda (1976) ${ }^{40}$, Grã-Bretanha, Irlanda e Noruega (1991), Islândia (1993), França $(1994)^{41}$, Finlândia (1995), Eslovênia (1996), Dinamarca (1996), Estônia (1998), Bélgica (1999), Suíça e Polônia (2003), Portugal (2007) e Espanha (2010), cada qual, a bem da verdade, com especificidades no tratamento legislativo adotado ${ }^{42}$.

\footnotetext{
${ }^{38}$ Segundo PERCY CAVERO, em 1953, o Congresso Alemão de Juristas reafirmou a incapacidade penal das pessoas jurídicas sob o argumento de que careciam de capacidade de ação. Esta fundamentação principal decorreu, também, do fato de que, à época, a teoria do delito era debatida em especial com relação ao conceito de ação. Id. Ibid., p. 63-64.

${ }^{39}$ Afirma BAIGÚN: "En el contexto de la globalización, los requerimientos de las corporaciones, por su actividad en el mercado o en el mercado o en el llamado espacio de rivalidad, ponen en escena, inexcusablemente, a la persona jurídica, su ropaje normativo; como lo hemos reiterado, son los sujetos de la acción, tanto en la esfera legitimada como en la que se registran los hechos reprobados socialmente.". BAIGÚN, David. La responsabilidad penal de las personas jurídicas: ensayo de un nuevo modelo teórico. Buenos Aires: Depalma, 2000, p. 11.

${ }^{40} \mathrm{~A}$ Holanda foi o país precursor, no continente europeu, da previsão da responsabilidade penal da pessoa jurídica. A crise econômica dos anos 20 e a situação no entre guerras mundiais impuseram a necessidade, por meio do Direito Público e, mais especificamente, do Direito Penal, de regular a vida econômica. Assim, no início dos anos 50 sobrevém a "Wet op Economische Delicten" (WED), a qual reconheceu em seu artigo 15 a pessoa jurídica como autora de delitos, ainda que no específico campo econômico. No âmbito do Código Penal, em 1965, dá-se um primeiro passo em direção à responsabilidade penal da pessoa jurídica reconhecendo-se a possibilidade desse ente figurar como autor, ainda que, à época, a responsabilização por tal autoria recaísse sobre os administradores ou membros do conselho de administração, vigindo a ideia de que societat delinquere potest, sed non punit potest. Apenas, então, em 1976, é que o Código Penal holandês vai trazer a previsão ampla de uma responsabilidade penal da pessoa jurídica, voltada para todos os tipos de delitos. Sobre o tema, ver: VERVAELE, John A. La responsabilidad penal de y en el seno de la persona jurídica en holanda. Matrimonio entre pragmatismo y dogmatica jurídica. In: REYNA ALFARO, Luis Miguel (coord.). Nuevas tendencias del derecho penal económico y de la empresa. Lima: Ara Editores, 2005, p. 469 e ss.

${ }^{41}$ É bem verdade que a responsabilidade penal da pessoa jurídica foi consagrada no Direito francês pelo Código Penal que entrou em vigor em 01 de março de 1994, especificamente no artigo 121-2, articulado esse que teve a redação alterada pela Lei $n^{\circ}$ 2003-204, de 9 de março de 2004. Contudo, essa previsão não é inédita se tivermos em conta que uma Ordenança de 1670 havia disposição regulando a instrução criminal contra "corpos e comunidades". Essa constatação é feita por ABOSO e ABRALDES: "La ultima reforma legislativa en materia penal operada em Francia avanza sobre este aspecto, texto legal que prevé, en su art. 121-2, el principio general de responsabilidad penal de las personas jurídicas (personne morale). Esta incorporación no resulta del todo novedosa si se tiene en cuenta que la ordenanza de 1670 regulamentó, dentro del título XXI, la instrucción criminal contra los cuerpos e comunidades". ABOSO, Gustavo Eduardo; ABRALDES, Sandro Fabio. op. cit. p. 6. Sobre o tema, ver, também: ZULGADÍA ESPINAR, José Miguel. La responsabilidad penal de empresas, fundaciones y asociaciones: Presupuestos sustantivos y procesales. Valencia: Tirant lo blanch, 2008, p. 54-55.

${ }^{42}$ Sobre isso, ver: CARBÓNELL MATEU, Juan Carlos; MORALES PRATS, Fermín. Responsabilidad penal de las personas jurídicas. In: ÁLVAREZ GARCÍA, Francisco Javier. GONZÁLEZ CUSSAC, José Luiz. Comentarios a la Reforma Penal de 2010. Valencia: Tirant lo Blanch, 2010, p. 69.
} 
Presente esse breve espectro histórico, é possível perceber que as transformações sociais influenciaram a admissão ou não da responsabilidade penal dos entes coletivos. Constata-se, também, que a conformação da dogmática penal se deu sob a influência de um específico contexto histórico, voltando-se especificamente para a pessoa humana, conformação essa que pode não se mostrar mais suficiente diante das necessidades práticas dos presentes dias. Nesse sentido, cabe-nos, agora, analisar os argumentos atualmente postos como favoráveis e desfavoráveis à responsabilização penal da pessoa jurídica, acentuando, nesse aspecto, como o tema da culpabilidade se revela como pedra de toque em tal responsabilidade.

\subsection{Objeções dogmáticas à responsabilidade penal da pessoa jurídica}

Neste campo de fértil debate que constitui a responsabilidade penal da pessoa jurídica, parece obviedade dizer que os argumentos contrários à sua admissão fundam-se, especialmente, na incompatibilidade desse "sujeito" com os elementos da teoria do delito. Toma-se por óbvia tal argumentação dogmática na medida em que, como já exposto, a formatação dessa teoria teve por base a pessoa humana. Assim, as adaptações teóricas que se mostram necessárias à responsabilização criminal da pessoa jurídica parecem desvirtuar a própria natureza do Direito Penal.

É necessário, portanto, conhecer tais objeções para ponderá-las em face dos argumentos favoráveis à responsabilidade penal dos entes coletivos e para entender porque a culpabilidade, conquanto não seja o único ponto crítico aventado, tem especial relevância nesse debate.

\subsubsection{A ação}

A doutrina aponta como o "primeiro obstáculo insuperável da proposta de criminalização da pessoa jurídica"43, a inexistência de uma ação própria da empresa no sentido jurídico-penal, em face da impossibilidade de verificação de uma vontade por ela emanada de forma independente dos seus componentes ${ }^{44}$. Nesse particular aspecto,

\footnotetext{
${ }^{43}$ SANTOS, Juarez Cirino dos. Responsabilidade penal da pessoa jurídica. In: PRADO, Luiz Regis; DOTTI, René Ariel (coord.). Responsabilidade penal da pessoa jurídica: Em defesa do princípio da imputação subjetiva. 2.ed. São Paulo: Revista dos Tribunais, 2010, p. 271.

${ }^{44}$ Nesse sentido, consigna SHEILA JORGE SElim DE SALlES: "Com efeito, a pessoa jurídica não pode ser sujeito ativo do fato, por não possuir capacidade de ação, já que o fenômeno volitivo, ínsito no fato
} 
ressalta-se que a definição conceitual de ação, independentemente do modelo teórico $\operatorname{adotado}^{45}$, é fenômeno exclusivamente humano, de forma que a incapacidade de conduta da pessoa jurídica deriva de sua própria essência, posto que sua "ação institucional" nada mais é do que uma "atividade imputada", no sentido de que os efeitos jurídicos derivados dessa atividade são originados não de uma autoria própria da pessoa coletiva, mas da conduta de seus representantes ${ }^{46}$. Reafirma-se assim, que a ação ou a omissão, como resultados de um "poder de decisão pessoal entre fazer ou não fazer alguma coisa" são "atributos inerentes às pessoas naturais" 47 . A vontade, como elemento integrante da ação, é considerada do ponto de vista psicológico (não normativo), de forma que apenas seria atribuível à pessoa física ${ }^{48}$.

Para alguns autores, aliás, a pessoa jurídica não passaria de mero instrumento do crime, de forma que a persecução penal e o aprimoramento de seu instrumental deveria se voltar para as ações humanas ${ }^{49}$. Chega-se a afirmar que as justificativas em sentido contrário, fundadas numa pretensa instrumentalização dos órgãos componentes da estrutura empresarial pelo próprio ente coletivo, como ocorreria nas construções que buscariam fundar a responsabilização penal das pessoas jurídicas na "autoria mediata", seriam $\operatorname{absurdas}^{50}$. Desse modo, responsabilizar-se penalmente a pessoa jurídica seria afrontar o

penalmente relevante, é peculiar ao ser humano e dele não se cogita em relação aos entes coletivos.”. SALLES, Sheila Jorge Selim. Princípio societa delinquere non potest no direito penal moderno. In: PRADO, Luiz Regis; DOTTI, René Ariel (coord.). Responsabilidade penal da pessoa jurídica: Em defesa do princípio da imputação subjetiva. 2.ed. São Paulo: Revista dos Tribunais, 2010, p. 212.

${ }^{45}$ Assim afirma CIRINO DOS SANTOS: "O conceito de ação, como fundamento psicossomático do conceito de crime, ou substantivo qualificado pelos adjetivos do tipo de injusto e da culpabilidade, representa fenômeno exclusivamente humano, inconfundível com o conceito de ação institucional atribuído à pessoa jurídica, segundo qualquer teoria: a) para o modelo causal, a ação seria comportamento humano voluntário; b) para o modelo final, a ação é acontecimento dirigido pela vontade consciente do fim; c) para o modelo social, a ação representa comportamento humano de relevância social dominado ou dominável pela vontade; d) para o modelo pessoa, a ação constitui menifestação da personalidade etc.”. SANTOS, Juarez Cirino dos. SANTOS, Juarez Cirino dos. Responsabilidade penal..., p.271.

${ }^{46}$ PRADO, Luiz Régis. Responsabilidade penal..., p. 128. No mesmo sentido, esclarece HEFENDEHL que a objeção à responsabilidade penal da pessoa jurídica fundada na incapacidade de ação, na Alemanha, tem por argumento que "las corporaciones solamente puede actuar porque existen indivíduos que pueden actuar en su nombre.”. HEFENDEHL, Roland. La responsabilidad penal corporativa: Artículo 2.07 del Código Penal modelo y el desarrollo en los sistemas legales occidentales. In: REYNA ALFARO, Luis Miguel (coord.). Nuevas tendencias del derecho penal económico y de la empresa. Lima: Ara Editores, 2005, p. 423.

${ }^{47}$ DOTTI, René Ariel. A incapacidade..., p. 169.

${ }^{48}$ BAJO FERNÁNDEZ, Miguel; BACIGALUPO, Silvina. Derecho penal..., p. 121.

${ }^{49}$ CONSTANTINO, Carlos Ernani. Outros aspectos da responsabilidade da pessoa jurídica. Boletim IBCCRIM, n. 74, p. 1-2, jan. 1999. Nesse sentido, também, PRADO, Luiz Régis. Responsabilidade penal..., p. 136

${ }^{50}$ Nesse sentido, afirma FEIJóo SÁNCHEZ: “[...] las equiparaciones con la autoría mediata dejan al descubierto el problema de fondo: la persona jurídica es el instrumento en manos del "hombre de trás" (la persona física que toma las decisiones que luego ejecutan otros). Imaginarse a una persona jurídica instrumentalizando a sus órganos de decisión no es más que un dislate.”. FEIJÓO SÁNCHEZ, Bernardo. Sanciones para empresas por delitos contra el medio ambiente: Presupuestos dogmáticos y criterios de imputación para la intervención del 
princípio "nullum crime sine conducta",

A falta de capacidade de ação da pessoa jurídica foi argumento central para fundar a inadmissibilidade de sua responsabilização penal, sobretudo quando o conceito de ação era o tema principal das discussões da teoria do delito na denominada "luta de escolas" $" 52$.

\subsubsection{A culpabilidade}

A falta de culpabilidade vem sendo entendida como o fundamento principal, na atual discussão penal, para não se admitir a responsabilidade penal da pessoa jurídica ${ }^{53}$.

As críticas embasadas em tal argumentação emergem da constatação inicial de uma incompatibilidade de objeto, posto que o juízo contido na culpabilidade voltar-se-ia para a conduta humana. Na doutrina brasileira, ressalta-se que, principiologicamente, a culpabilidade deriva da "dignidade da pessoa humana" (artigo $1^{\circ}$, inciso III, da Constituição Federal), fundamento de nossa República ${ }^{54}$. Ou seja, sua existência relacionase ao indivíduo, e não ao ente coletivo.

De outra banda, dissecando-se os elementos formais componentes da culpabilidade (imputabilidade, potencial consciência da ilicitude e inexigibilidade de conduta diversa), salienta-se que, em tais aspectos, a incompatibilidade da culpabilidade penal com a própria essência da pessoa jurídica é patente, posto que tais critérios foram delineados com base na constituição psíquica do indivíduo ${ }^{55}$, em sua consciência, embasando-se em avaliações biopsicológicas e na liberdade tanto na formação da "consciência do proibido" como do próprio "itinerário do delito" 56 , o que não se revela na atividade da pessoa jurídica, que sempre dependerá de uma ação humana. Assim, haveria

\footnotetext{
Derecho Penal contra las empresas. Madrid: Civitas, 2002, p. 78-79.

${ }^{51}$ ZAFFARONI, Eugênio Raul. PIERANGELLI, José Henrique. Manual de Direito Penal Brasileiro. São Paulo: Revista dos Tribunais, 2001, p. 409-410.

${ }^{52}$ Nesse sentido, constata PERCY GARCIA CAVERo que “[...] en 1953 se discutiera en el Congreso Alemán de Juristas la cuestión de si la persona jurídica podía cometer delitos o no. La opinión dominante fue entender que la persona jurídica no podía terner responsabilidad penal por carecer fundamentalmente de capacidad de acción. La importancia que tuvo el argumento de la falta de capacidad de acción se explica por el hecho de que en esse momento el concepto de acción era un tema central en la discusión sobre la teoria del delito (la llamada lucha de escuelas)." GARCÍA CAVERO, Percy. La persona jurídica..., p. 63-64.

${ }^{53}$ Afirma GARCÍA CAVERO: "En la actual discusión penal, el primeer escollo dogmático para poder hacer penalmente responsables a las personas jurídicas radican en sua falta de capacidad de culpabilidad". Id. Ibid., p. 66.

${ }^{54}$ DOTTI, René Ariel. A incapacidade..., p. 178.

${ }^{55}$ LUISI, Luiz. Notas sobre..., p. 38-39.

${ }^{56}$ DOTTI, René Ariel. A incapacidade..., p. 179.
} 
na culpabilidade um "substrato psicológico"57 imprescindível e impossível de compatibilização com o ente coletivo.

Refuta-se, ainda, as concepções fundadas em categorias sociais (como a culpabilidade por defeito de organização), sob o fundamento de que nada mais representariam do que a adoção de um argumento ficcional, posto que a deficiência organizativa é originada da atuação dos dirigentes do ente coletivo, de forma que tais construções resultariam na assunção de uma culpabilidade fundada em fato alheio ${ }^{58}$, o que, no limite, nada mais seria do que a negação do princípio da culpabilidade. Afirma-se, também, que os movimentos favoráveis a uma responsabilidade social são indefensáveis no campo do Direito Penal moderno, posto que esse se constrói sobre o elemento da culpabilidade do delito, o qual depende da imputabilidade. Tendo a imputabilidade um sentido biopsicológico, consistindo seu pressuposto a capacidade volitiva individual, nunca poderia a pessoa jurídica ser capaz de culpabilidade ${ }^{59}$.

Enxergam, dessa forma, na responsabilidade penal da pessoa jurídica, uma responsabilidade sem culpabilidade, ou seja, um retrocesso à admissão da responsabilidade objetiva no Direito Penal, sendo, portanto, impossível "medir a culpabilidade" ${ }^{, 60}$, tal como disposto no artigo 29 do Código Penal brasileiro, como forma de limitação do regresso ao infinito das relações de causalidade. Percebe-se nisso, também, um entrave à individualização da pena ${ }^{61}$, posto que, consoante a redação do artigo 59 do Código Penal brasileiro, a culpabilidade constitui um dos critérios reitores do dimensionamento da sanção.

\footnotetext{
${ }^{57}$ Afirma FeIJoÓ SÁNCHEZ: “[...] los requisitos de la culpabilidad en nuestro Código Penal tienen un substrato psicológico del que no se puede prescindir (responsabilidad subjetiva - dolo o imprudencia -, conocimiento de la antijuridicidad, exigibilidad del cumplimiento de la norma).". SÁNCHEZ, Bernardo Feijóo. Sanciones..., p. 68.

${ }^{58}$ PRADO, Luiz Regis. Responsabilidade penal..., p. 130. CARVALHO, Érika Mendes de; CARVALHO, Gisele Mendes de. Direito Penal de risco e responsabilidade penal das pessoas jurídicas. In: PRADO, Luiz Regis; DOTTI, René Ariel (coord.). Responsabilidade penal da pessoa jurídica: Em defesa do princípio da imputação subjetiva. 2.ed. São Paulo: Revista dos Tribunais, 2010, p. 255. Esse é o posicionamento, também, de RoBlEs Planas. Segundo o autor: "[...] este pretendido hecho propio simplemente no existe. Estamos, más bien, ante una ficción construída para dissimular la violación del principio de culpabilidad: tras el falso velo de la "culpabilidad penal de la persona jurídica" se oculta también aquí la culpabilidad de la persona física. En efecto, el hecho no es propio de la persona jurídica porque ella no pude actuar con independência de las personas físicas, de manera que el "defecto organizativo" es unicamente imputable a las personas físicas que lo han provocado o podían haberlo evitado.". ROBLES PLANAS, Ricardo. El "hecho propio" de las personas jurídicas y el Informe del Consejo General del Poder Judicial al Anteproyecto de Reforma del Código penal de 2008. InDret, n.2, p. 5, abr. 2009. Disponível em: 〈http://www.indret.com>. Acesso em: 06.06.2013.

${ }^{59}$ ZULGADÍA ESPINAR, José Miguel. La responsabilidad..., p. 71-72.

${ }^{60}$ DOTTI, René Ariel. A incapacidade..., p. 173.

${ }^{61}$ Id. Ibid., p. 180.
} 


\subsubsection{A pena}

As objeções à responsabilidade penal do ente coletivo remetem, ainda, ao campo das sanções. Nesse plano argumentativo, observa-se, em primeiro lugar, uma afronta ao princípio da personalidade das penas que, no Direito brasileiro, estaria consagrado no artigo $5^{\circ}$, inciso XLV, da Constituição brasileira de $1988^{62}$ Essa afronta deriva da constatação de que os efeitos sancionatórios recairiam sobre todos os componentes da pessoa jurídica, culpáveis ou não pleo fato, e não somente sobre os efetivos autores materiais do delito ${ }^{63}$.

De outro lado, refuta-se a responsabilização criminal da pessoa jurídica afirmando-se ser impossível individualizar sua pena (consoante o artigo $5^{\circ}$, inciso XLVI, da Constituição Federal ${ }^{64}$ ), na medida em que sua "atividade criminosa" sempre será referida à conduta humana de seus dirigentes ${ }^{65}$.

Afirma-se, ademais, que as finalidades de prevenção geral e especial, ou mesmo retributivas, não poderiam ser alcançadas nas sanções penais dirigidas à pessoa jurídica, reputando tal impossibilidade como consequência da ausência de substrato psicológico dos entes coletivos que os impediria de sentir os efeitos da pena ${ }^{66}$. Dessa forma, a pena dirigida à pessoa jurídica não possuiria seu sentido "moral", na medida em que, não possuindo consciência e liberdade, nunca poderia o ente coletivo decidir pela conduta conforme ou não ao Direito ${ }^{67}$.

\subsection{Questões político-criminais e dogmáticas favoráveis à responsabilidade penal da pessoa jurídica}

\footnotetext{
${ }^{62}$ Assim dispõe o aludido articulado "nenhuma pena passará da pessoa do condenado, podendo a obrigação de reparar o dano e a decretação de perdimento de bens ser, nos termos da lei, estendidas aos sucessores e contra elas executadas, até o limite do valor do patrimônio transferido".

${ }^{63}$ Nesse sentido: BAJO FERNÁNDEZ, Miguel; BACIGALUPO, Silvina. Derecho penal..., p. 120; PRADO, Luiz Regis. Responsabilidade penal..., p. 131.

${ }^{64}$ Dispõe o artigo, em sua parte inicial: "A lei regulará a individualização da pena..."

${ }^{65}$ Sobre isso, afiram JULIANO BREDA: "Se não é possível aplicarmos a sanção de maneira individualizada à pessoa jurídica, mas sempre tomando como referência a atuação de seu dirigente, não se preserva íntegro o princípio constitucional da individualização da pena. A individualização não pressupõe somente a existência de duas sanções a dois acusados, mas uma sanção penal verdadeiramente autônoma, especificamente voltada à pessoa condenada, com fundamento em uma responsabilidade própria e distinta do co-réu, diferenciada em razão de cada individualidade." BREDA, Juliano. Inconstitucionalidade das sanções penais da pessoa jurídica. In: PRADO, Luiz Regis; DOTTI, René Ariel (coord.). Responsabilidade penal da pessoa jurídica: Em defesa do princípio da imputação subjetiva. 2.ed. São Paulo: Revista dos Tribunais, 2010, p. 284.

${ }^{66}$ Nesse sentido: BAJO FERNÁNDEZ, Miguel; BACIGALUPO, Silvina. Derecho penal..., p. 121-122. PRADO, Luiz Regis. Responsabilidade penal..., p. 130. CONSTANTINO, Carlos Ernani. O art. $3^{\circ}$ da Lei $\mathrm{n}$. 9605/98 cria intolerável bis in idem. Boletim IBCCRIM, n. 72, p. 1, nov. 1998.

${ }^{67}$ ZULGADÍA ESPINAR, José Miguel. La responsabilidad penal..., p. 72.
} 
Reconhecido os principais argumentos dogmáticos opostos à responsabilidade penal da pessoa jurídica, é necessário delinear os fundamentos que embasam o discurso favorável a tal responsabilização, ressaltando, desde logo, que tais fundamentos não se limitam a questões político-criminais, encontrando também esteio na dogmática penal.

\subsubsection{O protagonismo das empresas nas relações sociais e em novas formas de criminalidade}

A questão fundacional sobre o tema da responsabilidade penal da pessoa jurídica tem se apoiado, essencialmente, em argumentos de política criminal. É mesmo recorrente na doutrina sobre o tema elencar-se "demandas de realidade" para apoiar a admissão dessa forma de responsabilização e para justificar o reflexo no campo legislativo.

Um dos principais argumentos que se traz à baila relaciona-se ao papel da empresa na sociedade moderna. O protagonismo da organização coletiva como forma de atuação social pode ser explicado por uma racionalidade econômica, em que a conjugação de fatores de produção coordenados em busca de um interesse comum, apoiada na especialização das atividades, se revela como um meio mais hábil de se alcançar essa finalidade. Sobretudo em âmbitos de atuação cuja persecução de um fim lucrativo orienta o desenvolvimento das atividades, é mesmo impossível pensar-se numa ação individualizada que seja efetiva para a consecução desses objetivos econômicos.

Nesse aspecto, deve-se ter em mente que a empresa surge como instrumento econômico de congregação de fatores em busca de uma maior eficiência para a consecução de fins (essencialmente lucrativos) comuns. Há nela a percepção de que a conjunção de elementos humanos e econômicos potencializa a ação no bojo social e o alcance dos objetivos de lucro.

A estruturação empresarial, contudo, vai se especializando ao longo da história, alcançando níveis organizativos tão complexos que o componente humano, que inicialmente era o protagonista máximo dessa organização, entendido como origem e fim de tais estruturas coletivas, acaba se diluindo nesse entramado organizativo, tornando-se mero ingrediente. Isto é perceptível pela própria história do desenvolvimento das empresas. Remotamente surgida com a ideia da compagnie toscana do século XII, entidade de caráter familiar, mas que já apresentava as características da pluralidade de sócios e 
personificação jurídica (ainda que incipiente, posto que a responsabilização dos sócios era ampla, alcançando, por vezes, sua própria vida) ${ }^{68}$, desenvolve-se no século XVI com a expansão do comércio ultramarino. Nessa época, a busca da exploração comercial de novas rotas se deu em dois modelos: exploração comercial direta pelos governos (modelo adotado por Espanha e Portugal) e exploração por meio de concessões a comerciante (adotado, por exemplo, pela Inglaterra, Holanda, Rússia e França) ${ }^{69}$, distinção essa que pode explicar o fracasso da exploração pelos países da península ibérica, que, em poucos anos, foram excluídos das rotas comerciais do Oriente ${ }^{70}$, revelando, já nessa época, a maior eficiência do modelo econômico empresarial privado.

Posteriormente, com a Revolução Industrial, a companhia alcança sua fase de independência, tanto de governos como de acionistas, pela liberdade de constituição e limitação de responsabilidade ${ }^{71}$, sendo mesmo alavancada pelo desenvolvimento das ferrovias e das máquinas a vapor, que permitiram seu direcionamento para a produção de bens. Todavia, é no fim do século XIX e começo do século XX que se cria um ambiente favorável para que as empresas adquirissem o papel social de protagonistas na economia e nas relações sociais, ambiente esse conformado pelo surgimento das grandes corporações, do consumo de massa e da economia de escala nos Estados Unidos da América ${ }^{72}$. Aliás, a experiência de abstração do conteúdo humano na composição da estrutura empresarial, com a especialização de atividades e divisão de funções, encontra sua expressão inaugural com ANDREW CARNEGIE e a implementação da primeira linha de montagem em suas indústrias ${ }^{73}$.

A história nos revela, então, o encaminhamento dessas estruturas coletivas para formas agigantadas e complexas, que perdem mesmo qualquer identificação com seus componentes humanos considerados individualmente. Aliás, a percepção da eficiência do

\footnotetext{
${ }^{68}$ Cf. NUNES, Marcelo Guedes. A Companhia, A Especulação e o Capitalismo Moderno: fazendo curta uma história longa. In: CASTRO, Rodrigo R. Monteiro; ARAGÃO, Leandro Santos de. Sociedade Anônima: 30 anos da Lei 6.404/76. São Paulo, Quartier Latin, 2007, p. 93.

${ }^{69}$ Id. Ibid., p. 93-94. Esclarece o autor, aliás, que "A primeira empresa do gênero, a já hoje esquecida Companhia Moscovita, foi um consórcio entre ingleses e holandeses, liderados por Sebastian Cabot e sir Hugh Willoughby, que recebeu em 1555 do czar Ivan IV uma concessão para a exploração das rotas entre Rússia e Inglaterra".

${ }^{70}$ Id. Ibid., p. 94.

${ }^{71}$ Afirma MARCELO NUNES que essa "primeira fase de formação" da companhia é alcançado com a Joint Stock Companies Act de 1865, na Inglaterra, quando se garantiu legalmente a liberdade de constituição e a limitação de responsabilidade dos sócios. Aliás, consigna o autor que a receptividade de tal Act pode ser percebida pela constituição, nos oito anos seguintes, de quase 25.000 novas companhias em território britânico. Id. Ibid., p. 100-101.

${ }^{72}$ Id. Ibid., p. 104.

${ }^{73}$ Id. Ibid., p. 107.
} 
coletivo e a abstração do individual têm apontado, também, para dois fenômenos comuns nos dias de hoje: o constante recurso a tipos societários anônimos e a formação de grupos econômicos. A adoção do mencionado modelo societário é recorrente por permitir a coisificação da posição acionária (ou seja, destitui-la de identificação pessoal) e sua circulação como mercadoria $^{74}$; por outro lado, a formação de grupos econômicos, seja de fato, de direito ou mesmo consórcios, revela a conjunção não apenas de indivíduos, mas de sociedades, que, congregando seus esforços empresariais, buscam a realização, com maior eficiência, de atividades comuns ${ }^{75}$.

O protagonismo econômico-social das empresas, reflete-se, por sem dúvida, num protagonismo penal. Parece evidente que, quantitativamente, as ações dotadas de relevância social serão cada vez mais emanadas de atuações coletivas do que de condutas individualizadas $^{76}$. De outro lado, qualitativamente, o agir conjunto com a congregação de fatores (quer materiais, quer humanos), potencializa esta atuação, dotando-a de maior capacidade de reverberação no bojo social $^{77}$. As consequências advindas da atividade empresarial terão a capacidade de atingir um espectro maior de pessoas e de bens, proporcionalmente à dimensão da estrutura organizacional que alcançam. A atuação de grandes empresas e corporações acaba não encontrando limites territoriais, podendo suas atividades produzir riscos ou danos que, por vezes, não são sequer passiveis de dimensionamento.

Esse contexto, de coletivização das atuações sociais, é acompanhado, também, pela percepção de uma "coletivização dos riscos e danos", deflagrando a necessidade de adaptação do Direito Penal a essas novas realidades, quer para a tutela de bens jurídicos

\footnotetext{
${ }^{74}$ Afirmam AlFRedo LAMy Filho e José Luiz BulHõEs PEDREIRA, ao tratar da divisão do capital social em ações: "Juntamente com a limitação de responsabilidade, outra característica revolucionária das sociedades por ações, que concorreu de forma substancial para a força expansiva de que é dotada, foi a divisão do capital social em alíquotas, incorporadas em títulos negociáveis que dão nome a sociedade, isto é, as ações. A incorporação do "status" de sócio num título ou valor mobiliário, negociável, e capaz de "circular como mercadoria (como rezava o art. 36 do estatuto do famoso "Banco de Law", cuja falência marcou um período da história econômica da França), completa a singularidade de que, no mundo jurídico e econômico, é dotada a S.A.”. LAMY FILHO, Alfredo; PEDREIRA, José Luiz (coord.), Direito das Companhias. v. 1. Rio de Janeiro, Forense, 2009, p. 5.

${ }^{75}$ COELHO, Fábio Ulhôa. op. cit.. p. 224.

${ }^{76}$ Constata SILVA SÁNCHEZ: "Las personas jurídicas constituyen, en efecto, los agentes económicos por excelencia y, a partir de ahí, son agentes sociales fundamentales.”. SILVA SÁNCHEZ, Jesús-María. Normas y acciones en Derecho penal. Buenos Aires: Hammurabi, 2003, p. 78.

${ }^{77}$ Afirma ZUÑIGA RODRíGUEZ que "de los cambios en las relaciones sociales actuales postindustrializadas, una de las características más importantes es la enorme masificación o colectivizacion de la sociedad, donde el poder de los indivíduos aislados há disminuido, siendo los sujetos colectivos los que están logrando un mayor poder de actuación.”. ZUÑIGA RODRÍGUEZ, Laura. Bases para un modelo de imputación de responsabilidad penal a las personas jurídicas. Pamplona: Aranzadi, 2000, p. 224-225.
} 
difusos ou transindividuais ${ }^{78}$, quer pela retomada da responsabilização penal da pessoa jurídica $^{79}$. Em campos como o do meio ambiente e da economia, a conflituosidade adquire outra feição, não podendo ser caracterizada como individual, mas como "conflito de sistemas" $" 80$.

O discurso político-criminal de há muito tem afirmado a necessidade de responsabilização penal dos entes coletivos, ponderando que a empresa moderna, complexa, não se confundindo com o pequeno negócio familiar, é uma realidade social que não pode ser interpretada como a mera soma de indivíduos ${ }^{81}$ e que, portanto, deve ser tratada tendo em vista suas peculiaridades. Tais características, que demandam o reconhecimento da responsabilidade penal deses entes coletivos, consideram, contudo, não só o aspecto externo das empresas, como protagonistas nas relações econômico-sociais por serem dotadas de capacidade de gerar riscos e danos em âmbitos de extrema relevância, como a economia e o meio ambiente, mas também suas configurações internas, que as tornam um agente criminógeno ${ }^{82}$, permitindo o que se denominou de "irresponsabilidade

\footnotetext{
${ }^{78}$ Neste sentido, afirma RENATO SILVEIRA que "O coletivismo, os interesses difusos, tão comuns e frequentes na sociedade moderna, impõem novas metas ao Direito. Ao mesmo tempo, depreende-se que, hodiernamente, é presente a orientação da necessidade de limitar o poder incriminador do Estado.". SILVEIRA, Renato de Mello Jorge. Direito penal..., p. 28.

${ }^{79}$ Assevera ZUÑIGA RODRÍGUEZ: "Desde el ámbito del riesgo para bienes jurídicos, sobre todo colectivos, y de la función de motivación que centra su atención en la dirección de la norma fundamentalmente dirigida a empresas (normalmente con posición de garante frente al bien jurídico), se ve claramente que los sujetos personas jurídicas o entes colectivos o sistemas complejos, pueden ser perfectamente sujetos de imputación penal. Es más, son ellas las que en los últimos tiempos están demonstrando que son los principales agentes de riesgos, conformando vários "accidentes" ("Unglück") que difícilmente se distinguem con el injusto (“Unrecht”).”. ZUÑIGA RODRÍGUEZ, Laura. Bases para un.... p. 224. Nesse sentido, também, constata TIEDEMANN que "las nuevas formas de criminalidad como los delitos económicos o de los negocios, en los que quedan comprendidos aquellos delitos cometidos contra el consumidor, los atentados al medio ambiente y el crimen organizado, son tan difíciles de ubicar en los sistemas y medios tradicionales del Derecho Penal que una nueva aproximación parece indispensable. No es por causalidad que el legislador en Europa continental haya admitido, en los años 20 del siglo pasado, o sea a partir del nacimiento del Derecho económico moderno, algunas excepciones al dogma "societas delinquere non potest", sobre todo en materia tributaria, aduanera o de la libre competencia.". TIEDEMANN, Klaus. TIEDEMANN, Klaus. Nuevas tendencias en la responsabilidad penal de personas jurídicas. In: op. cit., p. 401.

${ }^{80}$ Segundo RotH: "Se puede agregar que el derecho penal está confrontado a fenómenos que han devenido más complejos. El derecho (penal) del medio ambiente es aquí también un buen ejemplo, en tanto que "problema de conflicto de sistemas y no de conflictos individuales". La fórmula se aplica mutatis mutandi en todo el derecho penal económico.". ROTH, Roberth. Responsabilidad penal de la empresa: modelos de reflexión. In: HURTADO POZO, José; DEL ROSAL BLASCO, Bernardo; SIMONS VALLEJO, Rafael. La responsabilidad criminal de las personas jurídicas: una perspectiva comparada. Valência: Tirant lo blanch, 2001, p. 184.

${ }^{81}$ Cf. FEIJÓO SÁNCHEZ, Bernardo. Autoria e participação em organizações empresariais complexas. Trad. Vania Costa Ramos. Revista Liberdades, n. 9, p. 27, jan.-abr. 2012.

${ }^{82}$ Essa constatação foi feita por ZUÑIGA RODRÍGUEZ. Para a autora, "la Criminología nos demuestra que las empresas y las organizaciones son las principales agentes de riesgos para bienes jurídicos, riesgos que no son contenidos por el sistema penal. Así, que decir que las sociedades "no comenten delitos" es sólo verosímil en el ámbito teórico de Derecho Penal, mas no en la realidad criminológica." ZUÑIGA RODRÍGUEZ, Laura, Bases para un..., p. 227.
} 
organizada" $" 83$.

\subsubsection{A estrutura empresarial como facilitadora de crimes}

A complexidade estrutural das empresas modernas revela-se em uma série de características que, conjugadas, implicam na dificuldade de se individualizar responsabilidades por condutas delitivas.

A realidade da organização empresarial não permite confundi-la com a mera soma dos indivíduos que a compõem. A divisão de trabalho, característica da complexidade dos entes coletivos, aliena o agente individual do conteúdo total da coletividade em que atua, tornando a ação individualmente considerada dotada de significação diversa daquela que se revela na totalidade da atividade empresarial ${ }^{84}$. As lesões ou perigos derivados da atividade empresarial são resultados não da conduta concreta de uma pessoa, mas da conjunção de condutas nessa estrutura organizada ${ }^{85}$.

Essa impossibilidade de caracterização do conteúdo da ação parcialmente considerada é resultado, também, da descentralização das informações, que são fragmentadas em face da diferenciação funcional. Isso permite que os efeitos da atividade empresarial não sejam incorporados pelas empresas no mesmo sentido e velocidade com que as decisões são tomadas. Assim, é comum que o resultado da atividade coletiva seja primeiramente percebido pelos indivíduos em nível inferior, mais próximos, na cadeia empresarial, da ação concreta que gera o risco ou o dano, e desses se encaminhem às

\footnotetext{
${ }^{83}$ Afirma HEINE que "el fraccionamiento en el seno de la organización puede conducir hacia una "irresponsabilidad individual de carácter estrutural". A esto se agregan los mecanismos prácticos de encubrimiento al interior de la empresa. Existen muchas posibilidades de encubrir, inducir en error y generar vacíos que pueden a menudo hacer ineficaz cualquier indagación a causa de la estructura de la empresa “irresponsabilidad individual organizada”. Es por este que se señalan déficits en la prevención.”. HEINE, Günther. La responsabilidad penal de las empresas: evolución y consecuencias nacionales. Trad. Aldo Figueroa Navarro e José Hurtado Pozzo. In: HURTADO POZO, José; DEL ROSAL BLASCO, Bernardo; SIMONS VALLEJO, Rafael. La responsabilidad criminal de las personas jurídicas: uma perspectiva comparada. Valência: Tirant lo blanch, 2001, p. 52.

${ }^{84}$ Sobre isso, afirma GRACÍA MARTIN: "La división del trabajo determina que el hecho sea el resultado de la realización de una pluralidad de actos ejecutados por distintos sujetos en el ejercício de una competencia que es sólo fragmentaria com respecto a la actividade total de la empresa.". GRACIA MARTíN, Luis. Instrumentos de imputación jurídico penal en la criminalidad de empresa e reforma penal. In: Actualidad penal. 1/26, v.1, p. 214, 1993.

${ }^{85}$ Afirma ZUÑ̃GA RoDRÍGUEZ: “[...] abordarse los fenómenos de delitos cometidos en sistemas complejos en clave de sistema, empresa u organización, el hecho constatado científicamente, de que los peligros y lesiones de bienes jurídicos dentro de una empresa, son la mayoría de las veces resultado de defectos de una serie de conductas atribuibles a la organización de la própria empresa (políticas de empresa), que no pueden individualizarse en una concreta decisión de una concreta persona, sino en una deficiencia de largos años de falata de cuidado del riesgo consciente.”. ZUÑIGA RODRÍGUEZ, Laura. Bases para un..., p. 221.
} 
pessoas responsáveis pela tomada de decisão. Evidente, então, que além dessas decisões transcorrerem em sentido inverso na estrutura funcional da empresa, poderão sofrer um descompasso temporal que dificultará o conhecimento dos efeitos antes que haja a opção pelas ações ${ }^{86}$.

É perceptível, ainda, pela distinção funcional, a impossibilidade de se reconhecer, numa mesma pessoa física, a capacidade de decidir e executar ações, e o substrato informacional e técnico que gerará tal agir. De outra banda, sendo o indivíduo apenas um composto funcional nessa estrutura, é facilmente substituível por outra "peça humana" que cumpra a mesma função, sem que, nesta substituição, haja qualquer comprometimento da atividade empresarial.

Em suma, o entramado organizativo fundado numa divisão de trabalho, as decisões de grupo orientadas pelo fim societário diverso dos fins individuais, o agir coletivo que torna cada agente individual por vezes alheio ao resultado final de sua ação, transformam o humano em uma peça substituível e inconsciente nessa engrenagem ${ }^{87}$, inviabilizando mesmo a responsabilização individual. A conduta de um agente humano específico acaba, muitas vezes, sendo atípica para o Direito Penal, seja porque cada ato parcial não realiza o tipo objetivo, seja porque a pessoa física desconhece que sua ação compõe uma atividade criminal da empresa ${ }^{88}$. Nesse contexto, a pessoa jurídica não pode mais ser vista como instrumento, posto que, diante do formato complexo que adquiriu, acabou instrumentalizando o humano ${ }^{89}$.

\footnotetext{
${ }^{86}$ FEIJÓO SÁNCHEZ, Bernardo. Autoria e participação..., p. 28. Essa característica é, também, apontada por LAMPE, para seu "sistema de injusto constituído" que engloba as empresas. Descreve o autor: "Sin embargo, para asegurar la consistencia del todo existen entre los subsistemas canales de información. Dichos canales, por una parte, mandan órdenes del plano jerárquicamente superior (como instancia que emite talas normas) a los planos ocupados com tareas inferiores y, de ahí, a las personas a las que se les confia la realización de las tareas elementales. Por outra parte, en dichos canales fluyen, em sentido contrario, comentarios de los planos inferiores. Existe, por lo tanto, un intercambio de información en forma de un círuclo de reglas.". LAMPE, Ernst-Joachim. op. cit. p. 112-113.

${ }^{87}$ Constata FEIJÓO SÁNCHEZ: "Nas grandes empresas e sociedades potencialmente perigosas para bens jurídicos fundamentais, assiste-se a uma atomização ou fragmentação de movimentos corpóreos, decisões de política geral, conhecimento sobre riscos e recolha de informações pelas empresas sobre o seu impacto no ambiente circundantes, de tal modo que a partir de um certo grau de complexidade já não é possível encontrar uma pessoa na qual coincidam criação ou participação no risco, com representação desse mesmo risco, ou que disponha de informação global sobre a actividade empresarial.”. FEIJÓO SÁNCHEZ, Bernardo. Autoria e participação..., p. 28.

${ }^{88}$ Nesse sentido, afirma GRACIA MARTIN: "La división del trabajo determina que el hecho sea el resultado de la realización de una pluralidad de actos ejecutados por distintos sujetos en el ejercicio de una competencia que es solo fragmentaria con respecto a la actividad total de la empresa. Por esta razón, cada acto parcial se muestra a menudo atípico para el Derecho penal, sea porque no realiza por sí sólo el tipo objetivo, sea porque su autor desconoce que su acto está precisamente implicado en una más amplia actividad criminal de la empresa y entonces no realiza el tipo subjetivo.”. GRACIA MARTIN, Luis. op. cit. p. 214.

${ }^{89}$ Aqui ousamos discordar de alguns autores para quem seria absurdo reconhecer a instrumentalização do homem pela pessoa jurídica. Nesse sentido, afirma FEIJóo SÁNCHEZ: "Imaginarse a una persona jurídica
} 
A influência da estrutura empresarial na percepção de criminalidade pode ser reconhecida, também, na facilitação da atividade criminosa. A coletividade cria um ambiente que incita os indivíduos a cometerem delitos em benefício do grupo ${ }^{90}$. A busca pelo alcance de metas e pelo lucro a todo custo podem constituir uma filosofia empresarial que dá guarida a qualquer forma de atuação para a consecução desses fins ${ }^{91}$.

Não se pode olvidar, outrossim, do recurso, na estrutura empresarial, à eleição de um "responsável profissional", com a escolha de uma pessoa específica para suportar as imputações de responsabilidade, mediante recompensas financeiras ${ }^{92}$.

Diante de tal constatação, parece mais coerente afirmar que os fatos emanados da pessoa jurídica constituem expressão própria de sentido, que não se confunde com a expressão de sentido de cada um de seus componentes, pois é apenas na conjugação dessas atuações individuais que a atividade tomará corpo com o sentido pelo qual ela é captado pela sociedade. Bem por isso, pensar-se apenas na responsabilidade individual, além de injusto, será ineficaz ${ }^{93}$.

\subsubsection{A autorregulação como estratégia do Estado em face do aumento do poder empresarial}

O reconhecimento do protagonismo das empresas nas relações sociais, que se revela, sobretudo, em seu poderio econômico e técnico, associado ao deslocamento territorial da produção empresarial, que não se atém mais aos limites de um único Estado, reflexo mesmo da globalização, revelou a insuficiência da regulação intervencionista como instrumento para se conter os riscos da atividade empresarial. A complexidade da atividade

instrumentalizando a sus órganos de decisión no es más que un dislate.”. SÁNCHEZ, Bernardo Feijóo. Sanciones para empresas ..., p. 78-79.

${ }^{90} \mathrm{Cf}$. TIEDEMANN, Klaus. Nuevas tendencias..., p. 401.

${ }^{91}$ Cf. LAMPE, Ernst-Joachim. op. cit., p. 130-131.

${ }^{92}$ Afirma LuIS RODRIGUEZ RAMOS que "También cabe la posibilidad de que la sociedad "sacrifique" a una persona física, expresa o tácitamente, aun con el consentimiento del sacrificado, asumiendo todos los gastos de defensa jurídica, los costes de multas e indemnizaciones civiles e incluso ofreciendo al sacrificado una compensación económica por el deshonor y molestias que su papel le suponga.", RODRÍGUEZ RAMOS, Luis. Nuevos aspectos dogmáticos y procesales del principio "societas delinquere non potest". In: HURTADO POZO, José; DEL ROSAL BLASCO, Bernardo; SIMONS VALLEJO, Rafael. La responsabilidad criminal de las personas jurídicas: una perspectiva comparada. Valência: Tirant lo blanch, 2001, p. 171.

${ }^{93}$ Afirma ZuLGadía ESPINAR: “[...] una eficaz prevención de los hechos socialmente dañosos no puede llevarse a cabo operando exclusivamente sobre la base de la responsabilidad criminal individual.". ZULGADÍA ESPINAR, José Miguel. La admisión de la responsabilidad penal de las personas jurídicas: un pilar básico del moderno derecho penal económico. In: REYNA ALFARO, Luis Miguel (coord.). Nuevas tendencias del derecho penal económico y de la empresa. Lima: Ara Editores, 2005, p. 445. 
empresarial e de sua reverberação na sociedade vai além do mero reconhecimento das empresas como atores sociais dotados de grande poder, por vezes até superior ao dos Estados. Os modelos de organização pós-fordistas, frutos da revolução tecnológica, trazem a lume a concentração do conhecimento nas mãos destes entes coletivos, o que se soma a uma atividade que escapa dos limites territoriais, fugindo, portanto, da relação lei e território ${ }^{94}$.

Nesse contexto, pode-se dizer que a regulação estatal encara, em primeiro lugar, um problema de conteúdo, diante não só da dificuldade técnica de inserir em suas normas os conhecimentos relacionados às diversas áreas de atividades das empresas, como também de promover esta regulação em tempo adequado à rapidez das inovações tecnológicas. De outro lado, enfrenta um problema de imputação, pois deve regular uma atividade empresarial normalmente descentralizada, que vai muito além dos limites territorias do Estado. Soma-se, a isso, ainda, a incapacidade financeira estatal de suportar os altos custos demandados pelos processos de regulação, supervisão e sanção nestes âmbitos de alta complexidade ${ }^{95}$.

Diante do reconhecimento dessa deficiência técnica dos instrumentos de intervenção estatal, por assim dizer, buscaram-se alternativas que pudessem responder à necessidade de controle das empresas, em face de suas caracterísitcas de protagonistas nas relações econômico-sociais e geradoras de grandes riscos. Desse modo, reconhecendo-as como centros detentores de poder e conhecimento cuja atuação se dá de forma territorialmente difusa, não seria possível escapar de uma técnica de regulação que buscasse a própria colaboração desses entes no controle dos riscos de suas atividades. Nesse sentido, portanto, é que a autorregulação é utilizada como estratégia estatal.

A autorregulação é um mecanismo de regulação estatal misto, que foge da

\footnotetext{
${ }^{94}$ Cf. NIETO MARTÍN, Adan. La responsabilidad penal de las personas jurídicas: un modelo legislativo. Madrid: Iustel, 2008, p. 56-58.

${ }^{95}$ Como bem constata Ivó CoCA VILA: "El progresivo y constante aumento de la complejidad social, de los niveles de tecnificación y desarrollo tecnológico, sumado al avassalador proceso de globalización habrían despojado al Estado de la capacidade de regular de forma adecuada las estructuras empresariales. La especialización y la profesionalización por sectores de actividad, así como la complejidad de las estructuras organizativas y los correspondientes modelos de gestión haría absolutamente inviable sistemas generales de heterorregulación. A esta incapacidad, si se quiere, fáctica, se uniría además una profunda crisis del Estado social, de modo que éste ya no dispondría tampoco de la capacidad financiera para asumir los altos costes que los procesos de regulación, supervisión y sanción en ámbitos extremadamente complejos acarrean. En resumidas cuentas, el Estado ni tendría los recursos suficientes, ni sabría como hacerlo.”. COCA VILA, Ivó. ¿Programas de Cumplimiento como forma de autorregulación regulada?. In: SILVA SÁNCHEZ, Jesús-María (dir.); MONTANER FERNÁNDEZ, Raquel (coord.). Criminalidad de empresa y Compliance. Barcelona: Atelier, 2013, p. 45-46
} 
dualidade desregulação e heterorregulação (regulação estatal clássica) ${ }^{96}$, por meio do qual o Estado busca se valer das próprias empresas para alcançar uma normatização adequada aos objetivos de controle desse entes, bem como para conter e prevenir os riscos das atividades empresariais. Deve-se ressaltar, contudo, que tal estratégia não recorre à plena liberdade empresarial para definir seus rumos de regulação, mas sim se orienta pela busca de cooperação empresarial voltada para uma maior eficácia da intervenção estatal. Nesse aspecto, deve-se dizer que a autorregulação na gestão das atividades empresariais, como instrumento de regulação do Estado, não se embasa num argumento de autonomia, fundamento ideológico presente na ideia inicial de uma autorregulação como liberdade negativa, entendida como cláusula de não-intervenção estatal para o reconhecimento da autonomia política das empresas. Esse fundamento, aliás, se esfacela diante das crises do capitalismo e do aumento do poderio empresarial, que acaba conduzindo à necessidade de uma "autonomia responsável" $" 97$.

A autorregulação como estratégia de regulação estatal está mais afeta a argumentos tecnocráticos e democráticos ${ }^{98}$. Pelo fundamento tecnocrático, busca-se a eficiência tanto empresarial como pública, a primeira voltada, dentro do necessário controle dos riscos, à maximização da produção e rendimento da empresa, congregada com a necessidade de estruturação adequada para evitar práticas danosas em seu bojo (evitando, assim, também, o desvalor reputacional de uma atividade despreocupada com o entorno social); e a segunda com a consecução mais eficaz dos objetivos voltados para o interesse geral, que se mostrava inadequadamente alcançados com a intervenção estatal direta e que se veem favorecidos com a cooperação empresarial ${ }^{99}$. Já quanto ao fundamento democrático, sua relação com a autorregulação se revela pela inserção do interesse público nas decisões e na definição da organização empresarial, consequência mesmo do

\footnotetext{
${ }^{96}$ Id. Ibid., p. 45.

${ }^{97}$ Sobre isso, ver: MAROTO CALATAYUD, Manuel. Liberalismo versus neocorporativismo: los discursos de la autorregulación como discursos legitimantes. In: ZAPATERO, Luis Arroyo; LASCANO, Carlos; NIETO MARTÍN, Adán (dir.). Derecho penal de la empresa. Buenos Aires: Ediar, 2012, p. 414 e 417-422.

${ }^{98}$ Id. Ibid., p. 422-434.

${ }^{99}$ Como bem ressalta MAROTO CALATAYUD: "La idea del mercado autorregulado entronca con otra variante del argumento tecnocrático: la que entende la "eficiencia" como una "eficiencia pública", es decir, la que se hace depender de la consecución de fines de interés general. Lo vago del concepto de eficiencia permite que el argumento tecnocrático tome distintas formas que, por lo general, se sostienen sobre la idea de que el Estado se encuentra en una situación de inferioridade frente al sector privado en su capacidad para controlar determinadas realidades sociales. Surge así outro argumento muy común en favor de la privatización de la regulación: el de la mayor eficácia de los sistemas privados de control, de la autorregulación como forma eficaz de intervención pública.”. Id. Ibid., p. 425.
} 
reconhecimento do papel social das empresas ${ }^{100}$.

Admitindo o Estado, portanto, sua incapacidade de regular eficientemente as atividades empresariais, e reconhecendo o protagonismo desses entes coletivos nas relações sociais, com a detenção de conhecimentos técnicos necessários a uma adequada contenção dos riscos de suas atividades, deve buscar meios para congregar os objetivos públicos com os instrumentos privados, por assim dizer. Em outras palavras, deve o Estado concretizar um mecanismo para orientar essa capacidade empresarial de forma cooperativa com os objetivos estatais de contenção e prevenção dos riscos gerados pelas atividades desses entes coletivos.

Parece evidente, portanto, que a responsabilidade penal da pessoa jurídica revela-se como mecanismo de autorregulação empresarial, instrumentalizando as normas privadas em função dos objetivos de controle público ${ }^{101}$. Para tal instrumentalização, fomenta-se a estruturação empresarial ótima à prevenção e contenção de riscos (ou seja, práticas delitivas) em seu bojo, por meio de sanções positivas ou negativas às empresas.

Ao Estado, portanto, caberá definir os objetivos a orientarem essa organização empresarial, uma estruturação mínima para o alcance de tais fins e as sanções a serem impostas se sobrevier a prática de crime no bojo da empresa derivada da inadequada organização desse ente ${ }^{102}$. Deixa-se, portanto, um amplo espaço regulatório às próprias empresas, que definirão a melhor forma dessa estruturação de acordo com seus conhecimentos técnicos, adequados às peculiaridades de suas atividades. Contudo, deverão ter em conta, nessa sua "autodefinição", a busca pelo alcance ótimo dos objetivos estatais, de forma que a não estruturação de uma autorregulação adequada poderá gerar a responsabilização penal pelo advento da práticas delitivas em seu bojo.

Perceba-se, portanto, que a autorregulação é uma estratégia em que se permite dar efeitos jurídicos às próprias soluções adotadas pelas empresas ${ }^{103}$. Nesse sentido, o reconhecimento do protagonismo social desses entes coletivos pelo Estado reflete-se na assunção de deveres sociais que devem considerar ao desenvolver sua atividade. A incorporação dessa responsabilidade social pela empresa, portanto, demandará uma

\footnotetext{
${ }^{100}$ Id. Ibid; p. 433.

${ }^{101}$ NIETO MARTÍN, Adan. La responsabilidad..., p. 60.

${ }^{102}$ Teremos oportunidade de ver, mais a frente (em especial, no capítulo sexto), que esta estratégia sancionatória estatal pode se dar por meio da não responsabilização penal da empresa nos casos em que demonstrada a adoção de uma adequada estrutura ético-organizativa, como também pela diminuição da penalidade imposta quando houver tal demonstração.

${ }^{103}$ NIETO MARTÍN, Adan. La responsabilidad..., p. 62.
} 
definição organizativa voltada para a prevenção, contenção e detecção de riscos, como também para a revitalização da ética empresarial, que viabilizará uma gestão voltada não exclusivamente à consecução dos fins econômicos privados, mas também, para uma série de interesses influenciados pela atividade empresarial (como o meio ambiente, economia, saúde etc.). Não poderia o Estado, contudo, abrir mão de sua atividade regulatória e deixar a consecução desses fins públicos ao mero alverdrio empresarial. Constatando, contudo, a ineficiência da regulação direta, deve incentivar a estruturação ético-organizativa da empresa voltada para sua responsabilidade social. Nesse sentido, observando a importância dessa adequada estruturação para todo o entorno social, em face do amplo efeito da atividade empresarial e dos riscos por ela produzidos, o Direito Penal revela-se como instrumento a ser empregado nesse âmbito para fomentar de forma veemente essa organização empresarial.

Verifica-se, portanto, que a responsabilidade penal da pessoa jurídica é um instrumento de motivação coativa da auto-organização que funcionará como complemento de outros setores de fomento à autorregulação, como o Direito Administrativo ${ }^{104}$. Dada a importância da autorregulação empresarial, tendo-se em conta os efeitos sociais das atividades dos entes coletivos, não se poderia abrir mão do instrumento máximo de coação estatal, que é o Direito Penal, argumentando-se, para tanto, a existência de óbices dogmáticos ao reconhecimento da pessoa jurídica como sujeito ativo nesse âmbito.

Nesse sentido, o Direito Penal seria o instrumento adequado para funcionar em duas frentes de incentivo à autorregulação empresarial. Em primeiro lugar, pela sanção em si, cuja aplicação buscará ser evitada pela empresa com a adoção de uma organização ético-funcionalmente adequada (campo em que o Direito Penal não se diferencia do Direito Administrativo sancionador, na medida em que em ambos poderá haver a aplicação de sanções de natureza semelhante); e, em segundo lugar (e aqui parece haver a peculiaridade da responsabilidade de natureza penal), pela estigmatização proporcionada pela sanção penal, que promove, além do dano material, um dano reputacional à empresa, por vezes, com efeito muito mais negativo do que o prejuízo econômico direto produzido com a pena.

\footnotetext{
${ }^{104}$ Como bem constata NIETO MARTíN: "En suma, lo que queria subrayar con todo lo anterior es que: primero, la necesidad de instaurar la responsabilidad penal de la empresa responde a la perdida de eficacia del ordenamento jurídico; segundo, que la responsabilidad penal no es sino un mecanismo para motivar coactivamente a la autoorganización y, por ello, un instrumento de intervención estatal en el mercado que encuentra su legitimidade en el Estado social; tercero, esta línea de política jurídica está cada vez más extendida en el derecho administrativo o de sociedades, de modo tal que el derecho penal colectivo vendría a constituir un sistema de cierre que assegura su cumplimiento global y ademas completa las medidas de auotrregulación adoptadas en otros sectores.”. Id. Ibid., p. 66.
} 
Nesse sentido, o Direito Penal adequa-se comunicacionalmente ao âmbito empresarial, em que as estratégias de marketing têm especial valia às empresas ao gerar certo valor reputacional que compõe o patrimônio empresarial. A estigmatização presente no Direito Penal terá, portanto, uma aplicação racional no campo da responsabilização da pessoa jurídica, ao afetar um valor importante para as empresas, sem que, com isso, haja ofensa a princípios constitucionais, como por vezes se constata no caso da imputação individual $^{105}$.

\subsubsection{As deficiências dogmáticas presentes na responsabilização individual por delitos praticados na estrutura empresarial e a admissão da responsabilidade penal da pessoa jurídica como expressão de proteção da pessoa humana}

A constatação de que o indivíduo humano, integrado na complexa teia estrutural da empresa, se converte em mero ingrediente de uma nova forma de concretização de condutas criminosas, revela não só a ineficiência de se tratá-lo como agente único de delitos, como também a injustiça de tal opção. Isto porque, para se tentar imputar, na complexa estrutura empresarial, o delito a um indivíduo, acaba-se recorrendo a construções dogmáticas duvidosas. A busca irracional de uma responsabilização de um indivíduo na estrutura empresarial (até mesmo com o objetivo de se alcançar a indenização civil), fundada também no repúdio à responsabilidade penal da pessoa jurídica, tem conduzido, por vezes, à deformações dogmáticas muito mais criticáveis do que a adaptação dos elementos do crime à pessoa jurídica.

Não é difícil constatar, por exemplo, o recurso a delitos comissivos por omissão culposos em que a posição de garante funda a responsabilidade do indivíduo, revelando nessa construção afronta a princípios como o da culpabilidade e da responsabilidade subjetiva. Isto é perceptível, sobretudo, em estruturas organizativas em que a divisão de trabalho e a hierarquização fazem recair sobre diversas pessoas os

\footnotetext{
${ }^{105}$ Não se está a defender, aqui, um mero uso simbólico do Direito Penal. Pelo contrário, pensa-se que a responsabilização penal da pessoa jurídica se traduz no uso racional desta área do direito, pois, por mais que faça necessária a flexibilização da teoria do delito, ela se voltará para um sujeito específico, a pessoa jurídica, sem que isto possa indicar o relaxamento de garantias voltadas aos indivíduos. Não se descura, também, da existência de um efeito estigmatizante na publicidade dos processos e sanções administrativos. Reafirma-se, contudo, o caráter do Direito Penal como instrumento máximo de coação estatal, cuja utilização não pode ser negada em face de atores sociais tão relevantes como as pessoas jurídicas. Para críticas, contudo, a tal posicionamento: LOBO DA COSTA, Helena Regina. Proteção penal ambiental: viabilidade, efetividade, tutela por outros ramos do direito. São Paulo: Saraiva, 2010, p. 133-140 e 202-209.
} 
mesmos deveres derivados da posição de garante $^{106}$, posição essa que acaba sendo caracterizada apenas com apoio em juízos valorativos, não em constatações fáticas. A essa construção problemática soma-se, ainda, a própria indefinição da omissão relevante para a produção do risco ou resultado danoso, bem como a dificuldade de caracterização da culpa $^{107}$, que apenas tornam ainda mais duvidosos os caminhos percorridos para essa imputação.

Essas construções apegadas à busca por uma responsabilização individual por delitos praticados na estrutura empresarial parecem olvidar, também, que, diante da fragmentação das condutas individuais no entramado organizativo da corporação, cada ato parcial se revela atípico, não só porque, isoladamente considerado, não realiza o tipo objetivo, como também porque o autor individual desconhece, como já se disse linhas atrás, o conteúdo de sua conduta considerada como componente da atividade empresarial e, portanto, não realiza o tipo subjetivo. É possível, ademais, que os indivíduos que realizam a ação típica no bojo da empresa não possuam a qualidade constitutiva do elemento objetivo exigida pelo tipo $^{108}$.

Por outro lado, é igualmente questionável a justiça e conveniência de uma sanção penal dirigida exclusivamente a um agente individual quando o delito é emanação de um contexto criminalmente organizado e por essa organização não é o autor físico da ação responsável ${ }^{109}$.

Presente esse espectro, pugnar-se por uma responsabilização penal da pessoa jurídica, traduz-se numa manifestação de reafirmação das garantias individuais, deixandose de recorrer à responsabilização penal das pessoas físicas como primeiro e único meio de se promover o sancionamento de comportamentos de extrema danosidade social e que nem sempre estão vinculados a uma conduta humana determinada. A presença de outro

\footnotetext{
${ }^{106}$ Sobre isso, ver: RODRÍGUEZ RAMOS, Luis. Nuevos aspectos..., p 170. Afirma o autor: "En efecto, parece que existiendo una situación de garante, un incumplimiento de un deber derivado de la misma y un resultado previsible y/o evitable que no hubiera acaecido de haberse cumplido tal deber de actuar, la teoría jurídica del delito y, en particular, las exigencias de legalidad, imputación objetiva y culpabilidada no sufren quebranto alguno. Pero el problema de una efectiva responsabilidad objetiva de carácter penal surge cuando se profundiza en la estructura de los delitos culposos de omisión, especialmente en el ámbito de actuaciones en las que concurren, horizontal (división del trabajo) y verticalmente (jerarquización: otra modalidade de dividir el trabajo), en diversas personas, los mismos deberes derivados de la situación de garante.".

${ }^{107}$ Id. Ibid., p. 172.

${ }^{108}$ Id. Ibid., p. 214.

${ }^{109}$ Afirma GRACIA MARTín que "podría cuestionarse la conveniencia político-criminal y la justicia del castigo del autor que realiza el hecho punible en un contexto "criminalmente organizado" por outros sin ser responsable, sin embargo, de tal organización, pues la amenaza y efectiva imposición de la pena al autor que ocupa una posición subordinada en la jerarquía de la empresa puede erigirse de hecho y por la própria inercia de las cosas en un serio obstáculo a la persecución y castigo de quienes configuran realmente la "disposición (actitud) criminal de la empresa". GRACIA MARTÍ́N, Luís. op. cit, p. 214-215.
} 
mecanismo de responsabilização criminal permite fugir do simbolismo da penalização dos indivíduos por meio de uma eleição virtual da posição de garante que representa, a bem da verdade, uma responsabilidade penal objetiva e arbitrária ${ }^{110}$. O recurso exclusivo ao sancionamento das pessoas físicas corre o risco de contaminar todo o sistema de responsabilidade individual com as "ânsias de adaptabilidade", promovendo, no limite, construções que apontam para a negação das próprias garantias voltadas aos indivíduos ${ }^{111}$.

\subsection{A culpabilidade como problema central na responsabilidade penal da pessoa jurídica}

Nesse embate entre as questões dogmáticas levantadas pela doutrina oposta à responsabilidade penal da pessoa jurídica, e os argumentos favoráveis à admissão dessa responsabilização, parece que os legisladores têm dado ouvidos aos reclamos deste último posicionamento. A crescente admissão da responsabilidade penal das pessoas jurídicas pode ser notada por um simples passar de olhos nas legislações dos mais diversos países ${ }^{112}$. Assim, por exemplo, em Holanda (1976), Grã-Bretanha, Irlanda e Noruega (1991), Islândia (1993), França (1994), Finlândia (1995), Eslovênia (1996), Dinamarca (1996), Brasil (1996), Estônia (1998), Bélgica (1999), Suíça e Polônia (2003), Portugal (2007), Chile (2009) e Espanha (2010) $)^{113}$.

\footnotetext{
${ }^{110}$ Pondera RAMOS: “[...] la aplicación del axioma societas delinquere non potest, baseado en los principios de culpabilidad y de imputación objetiva, sirve para conculcar subrepticiamente tales principios y algún otro. Estatuyendo una responsabilidad penal objetiva y arbitraria - sin fundamentos de imputación - respecto a ciertas personas físicas.[...] Es decir, al ser inviable la imputación penal directa de la persona jurídica, se elige, de manera bastante aleatoria, a uno o vários seres humanos como meros instrumentos de inculpación penal y civil de las empresas en las que trabajan.”. RODRÍGUEZ RAMOS, Luis. Nuevos aspectos..., p. 168.

${ }^{111}$ Afirma ZUÑIGA RoDRÍGUEZ: “[...] la opción de seguir flexibilizando las categorías penales existentes para responder a la macrocriminalidad, corre el riesgo de "contaminar todo el sistema de responsabilidade individual de esas ansias de "adaptabilidad", pudiendo desembocar en una pérdida de validez de las garantías ganadas y construidas durante dos siglos.”. ZUÑ̃IGA RODRÍGUEZ, Laura. Bases para..., p. 220-221.

${ }^{112}$ Fazendo uso da expressão utilizada por SILVA SÁNCHEZ, pode-se dizer que há uma "tendência internacional" à incorporação dos modelos de responsabilidade penal da pessoa jurídica, o que não se confunde com uma resposta à influência do Direito Internacional. SILVA SÁNCHEZ, Jesús-Maria. La responsabilidad penal de las personas jurídicas en derecho español. In: SILVA SÁNCHEZ, Jesús-María (dir.); MONTANER FERNÁNDEZ, Raquel (coord.). Criminalidad de empresa y compliance: Prevención y reacciones corporativas. Barcelona: Atelier, 2013, p. 20. Compreende-se tal distinção quando se observa, por exemplo, que a Convenção das Nações Unidas contra a Criminalidade Organizada Transnacional, de 2000, a Convenção das Nações Unidas contra a Corrupção (Convenção de Mérida, de 2003); no âmbito da União Europeia, a Decisão Marco relativa à luta contra a criminalidade organizada, de 2008/842 JAI, do Conselho de 24 de outubro de 2008, todas elas, apesar de orientarem a responsabilidade da pessoa jurídica, não exigem que seja de natureza penal. Para um maior aprofundamento do tema, ver: BRAVO, Jorge dos Reis. op. cit, p. $128-142$.

${ }^{113}$ Sobre isso, ver: CARBÓNELL MATEU, Juan Carlos; MORALES PRATS, Fermín. Responsabilidad penal de las personas jurídicas. In: ÁLVAREZ GARCÍA, Francisco Javier. GONZÁLEZ CUSSAC, José Luiz.
} 
Percebe-se, aliás, que a admissão da responsabilidade penal das pessoas jurídicas está se dando em países de sistema jurídico de influência romano-germânica, em que vigoraria, em tese, o princípio "societas delinquere non potest",114 . A crescente opção dos legisladores pela responsabilidade penal da pessoa jurídica pode ser justificada não só pelos argumentos de política criminal anteriormente expostos, que levam à crença de uma ineficácia e injustiça na persecução penal exclusiva das pessoas físicas, como também por argumentos funcionais, como a existência de instrumentos probatórios mais amplos e eficazes na seara processual penal (por exemplo, no específico caso brasileiro, a interceptação telefônica ${ }^{115}$ ), e a necessidade de uma cooperação internacional que pode ser facilitada quando uma mesma conduta e uma mesma sujeição ativa é prevista em diferentes ordenamentos.

Deve-se ter em mente, também, como já se disse, que o sancionamento exclusivo das pessoas físicas pode ter um efeito negativo, no sentido de que não impede o prosseguimento da atividade delitiva, posto que esta se estrutura no conjunto empresarial, e não no indivíduo, sendo a pessoa física, na maioria das vezes, substituível, sem que com isso haja qualquer alteração da atividade da empresa. Se isso não bastasse, uma condenação dirigida ao indivíduo por crime empresarial gera a deformação de não caracterizar a reincidência da corporação ${ }^{116}$. Bem por isso, pensar-se a culpabilidade na responsabilidade da pessoa jurídica tem a importância de tentar solucionar tais questões práticas problemáticas.

Há, entretanto, na busca pela adequação dogmática da responsabilização penal da pessoa jurídica, em especial com relação à culpabilidade, uma face garantista voltada para o ente coletivo que muitas vezes é olvidada no discurso doutrinário, e que, ao que nos

Comentarios a la Reforma Penal de 2010. Valencia: Tirant lo Blanch, 2010, p. 69. Não se inclui na lista a Itália, diante da peculiaridade da regulação contida no Decreto Legislativo 231/2001, que não prevê expressamente uma responsabilidade penal das pessoas jurídicas, mas aplica as sanções no bojo de um processo penal. Teremos oportunidade de detalhar melhor tal regulação no capítulo sexto, item 6.3.

${ }^{114}$ Assevera ZULGADÍA EsPINAR: "A nivel legislativo debe tenerse en cuenta la existencia en el campo del Derecho Comparado de dos corrientes jurídicas diferentes: la del grupo de países sometidos al sistema jurídico del Common Law, que admiten la responsabilidad criminal de las personas jurídicas y la corriente representada por los países del sistema jurídico románico-germánico y las Repúblicas Populares europeas, fieles a la concepción clásica del societas delinquere no potest [...]. En el campo del Derecho continental, los argumentos esgrimidos por quienes son partidarios de exigir responsabilidad criminal a las sociedades va ocasionando fisuras cada vez más importantes en la posición tradicional.”. ZULGADÍA ESPINAR, José Miguel. La responsabilidad..., p. 53.

${ }^{115}$ Consoante dispõe o artigo $5^{\circ}$, inciso XII, da Constituição Federal. Deve-se rememorar, contudo, que o Superior Tribunal de Justiça admitiu, em caráter excepcional, a interceptação telefônica no âmbito civil

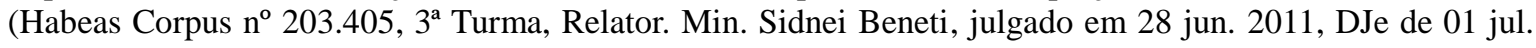
2011).

${ }^{116}$ Sobre o tema, conferir: ROTH, Roberth. Responsabilidad penal..., p. 185-186. 
parece, tem fundamental importância no tema que se propõe analisar. Afinal de contas, ao se buscar fundamentar materialmente um juízo de reprovação penal dirigido aos entes coletivos, seja este fundamento centrado numa construção de culpabilidade (própria da pessoa jurídica, ou comum também à pessoa física), seja em outras concepções (como, por exemplo, o estado de necessidade do bem jurídico), dever-se-á, com tal formulação, dotar o aplicador do direito de um instrumental para mensurar de forma proporcional e justa as sanções, assegurando que o poder punitivo estatal não se exercerá ilimitadamente. Esse é, portanto, um ponto de fundamental importância que se deverá considerar na tentativa de compatibilizar a culpabilidade (ou outra construção que a substitua) com a responsabilidade criminal dos entes coletivos, servindo como critério valorativo para avaliar os modelos teóricos já construídos com relação ao tema.

Se as demandas de realidade - e muito mais que isso, as demandas de correção dogmática e de afirmação de princípios, promovendo verdadeira consagração da responsabilização subjetiva da pessoa física - têm orientado o discurso legislativo, não se pode permitir que a dogmática se converta num fim em si mesmo ${ }^{117}$. Os dogmas são, em verdade, escolhas de certos sentidos dentro de uma cadeia argumentativa, sem que haja um fundamento último para tal eleição. Assim, a escolha de um sentido para algum conceito se trata apenas de uma opção, de uma decisão, não uma constatação de realidade, no sentido de que apenas há um sentido válido ${ }^{118}$.

Não se está com isso, é bem verdade, pugnando pelo completo abandono dos elementos identificadores do Direito Penal que o dotam de cientificidade. De forma oposta, crê-se que permitir o completo descompasso da Ciência do Direito Penal da realidade que o envolve é retirar seu caráter de ciência humana. Assim, melhor, decerto, diante das demandas político-criminais (e principiológicas) que se impõem, tentar compatibilizá-las com as exigências dogmáticas da Ciência Penal, buscando com isso dotar o aplicador do

\footnotetext{
${ }^{117}$ Nesse sentido, HEFENDEHL, citando SCHÜNEMANN, afirma que este último autor constatou que a "continua pasividad de la legislatura Alemana lleva a un injustificable fin en si mismo de principios dogmáticos que fueron originalmente desarrollados para delitos cometidos por indivíduos. Estos principios no habrían de ser adecuados para dirigir el ámbito de la delincuencia corporativa porque el proceso de interacción inherente en tales casos es totalmente diferente de aquellos que caracterizan las interacciones de los indivíduos. Por conseguiente, la prevención del delito corporativo además debe ser manejado por diferentes reglas.". 45 HEFENDEHL, Roland. La responsabilidad..., p.420.

${ }^{118}$ Nesse sentido, constata ZULGADÍA ESPINAR que: “[...] como los dogmas de la dogmática no son sino decisiones y elecciones primeras de cadenas argumentales no susceptibles de una fundamentación última, no es posible considerar que existe un único concepto válido de acción (como comportamiento humano voluntario) y un único concepto válido de culpabilidad (como juicio de base bio-psicológica). Tales concepciones son posibles, pero no excluyen ni otros conceptos distintos de acción y de culpabilidad.”. ZULGADÍA ESPINAR, José Miguel. La admisión..., p. 459.
} 
direito de um instrumental adequado e hábil para dar concretude à responsabilização penal da pessoa jurídica. Está-se, dessa forma, optando pelo reconhecimento da dogmática como veículo, não como obstáculo ${ }^{119}$.

Passamos então, adotando as palavras de LAURA ZUÑIGA RoDRÍGUEZ, da “etapa do se da responsabilidade penal das pessoas jurídicas, para adentrarmos no como fazê10"120. E, nessa etapa, em que se pretende construir elementos para realizar a responsabilidade penal da pessoa jurídica sem desvirtuar os princípios da Ciência Penal, o déficit de subjetividade do ente coletivo, refletido, em especial, na culpabilidade, constitui o problema central a se tratar.

A escolha da culpabilidade como objeto de análise no tema da responsabilidade penal da pessoa jurídica não se dá, portanto, de forma aleatória. Relaciona-se, mesmo, com a centralidade desse elemento, não apenas nos debates relacionados à construção dogmática de uma responsabilidade penal da pessoa jurídica ${ }^{121}$, como também nas discussões doutrinárias atuais sobre a própria teoria do delito ${ }^{122}$, que apontam, aliás, para uma crise conceitual. Essa crise pode ser identificada pela crítica à vinculação da

\footnotetext{
${ }^{119}$ Adotamos, aqui, o pensamento de ZULGADíA ESPINAR, ao fazer menção a um artigo por ele publicado em 1980. Afirma o autor: "Convencido de que el Derecho Penal y la dogmática penal debían ser el vehículo (¡nunca el obstáculo!) para realizar los necesarios fines de política criminal en relación a la prevención del delito (independientemente de quienes fuesen sus autores), en el proponía que se determinara en qué delitos y bajo que condiciones debían imponerse sanciones penales a las personas jurídicas y que, para hacerlo posible, se revisaran o ampliaran los conceptos tradicionales de acción (como conducta humana), culpabilidade (como juicio bio-psicológico) y pena (como castigo retributivo de la culpabilidad).” Id. Ibid., p. 441-442.

${ }^{120}$ Afirma a autora: "Lo cierto es que parece haberse superado la etapa del sí de la responsabilidad penal de las personas jurídicas, para adentrarmos en el cómo hacerlo.”. ZUÑIGA RODRÍGUEZ, Laura. La responsabilidad penal de las personas jurídicas en el Anteproyecto de Código Penal peruano de 2009, p. 154. Disponível em: <perso.unifr.ch/derechopenal/assets/files/anuario/an_2009_08.pdf>. Acesso em: 13 abr. 2012.

${ }^{121}$ Essa constatação foi feita por CARLOS GÓMEZ-JARA DíEZ: "De entre los diferentes problemas que presenta la instauración de um modelo de responsabilidad penal empresarial, la determinación de la culpabilidade empresarial goza de un lugar privilegiado. No en vano la imposibilidad de compatibilizar el principio de culpabilidade con la organización empresarial se há erigido em el bastión irreductible de la doctrina tradicional, habiéndose incluso afirmado que el principio societas delinquere non potest se há impuesto como expresión del principio no hay penal sin culpabilidade. Así, puede constatasse la existência de vários autores que, pese a no tener mayores problemas com las otras categorias del delito, muestran sus dudas en lo que al principio de culpabilidade se refiere.”. GÓMEZ-JARA DÍEZ, Carlos. La responsabilidade penal de las personas jurídicas: el modelo constructivista de autorresponsabilidad penal empresarial. Lima: Ara, 2010, p. 43-44.

${ }^{122}$ Perceba-se que nem sempre a culpabilidade foi tema principal no debate sobre a teoria do delito, muito menos em relação à questão da responsabilidade penal da pessoa jurídica. Como constata GARCíA CAVERO: "El remecimiento del principio de la irresponsabilidad penal de las personas jurídicas por las instancias judiciales motivó que en 1953 se discutiera en el Congreso Alemán de Juristas la cuestión de si la persona jurídica podía cometer delitos o no. La opinión dominante fue entender que la persona jurídica no podía tener responsabilidad penal por carecer fundamentalmente de capacidad de acción. La importância que tuvo el argumento de la falta de capacidad de acción se explica por el hecho de que en esse momento el concepto de acción era un tema central en la discusión sobre la teoria del delito (la llamada lucha de escuelas).”. GARCÍA CAVERO, Percy. La persona..., p. 63-64.
} 
culpabilidade a critérios indemonstráveis, como o livre-arbítrio, e a tentativa de reformulação de seu conteúdo.

Já no que se refere à específica relação entre culpabilidade e responsabilidade penal da pessoa jurídica, é inegável que aquela tem sido o foco principal das discussões doutrinárias referentes aos problemas de admissão dessa nova forma de responsabilização ${ }^{123}$. Afinal, é nela em que se vislumbram os maiores obstáculos de compatibilização dessa modalidade de responsabilidade com a dogmática, essencialmente porque a culpabilidade constitui a máxima expressão da valoração do subjetivo e afronta, com maior agudeza, os "limites ontológicos da construção jurídica dos conceitos" " Nesse sentido, é patente a impossibilidade de percepção de uma autoconsciência e liberdade da pessoa jurídica, pelo menos em sua concepção voltada para o humano. É mais fácil a aceitação da possibilidade de imputação de comportamentos aos entes coletivos, bem como de riscos e danos derivados de sua atuação, apoiados no reconhecimento da pessoa jurídica como um âmbito de organização a que se pode atribuir socialmente certos fatos e defraudações de expectativas sociais essenciais ${ }^{125}$. As dificuldades residem, pensase, não só em se reconhecer a capacidade da pessoa jurídica de receber uma reprovação pessoal (própria), mas também (e principalmente) em se adotar um conceito de culpabilidade (ou equivalente) capaz de estabelecer limites à reprovação penal, para que não se converta em uma responsabilidade objetiva.

Palmar, então, o enfrentamento da culpabilidade na responsabilidade penal da pessoa jurídica, sendo necessário, para tanto, até em face das preocupações práticas que permeiam (e até justificam) o tema, delinear o estágio legislativo em que a questão da

\footnotetext{
${ }^{123}$ Afirma SILVA SÁNCHEZ que: "não cabe ninguna duda de que el centro de todas las discusiones acerca de la responsabilidad penal de las personas jurídicas es la culpabildad.”. SILVA SÁNCHEZ, Jesús-María. Normas..., p. 82.

${ }^{124}$ Aplicamos, aqui, a expressão utilizada por SILVA SÁNCHEZ ao tratar da impossibilidade do Direito reconhecer autoconsciência e liberdade para as pessoas jurídicas, conquanto pudesse atribuí-las a condição jurídica de sujeito. Id. Ibid., p. 82.

${ }^{125}$ Consigna GARCÍA CAVERO: "En la actual discusión penal, el primer escollo dogmático para poder hacer penalmente responsables a las personas jurídica radica en su falta de capacidad de culpabilidad. No obstante, que la persona jurídica conforma un ámbito de organización al que se le pueden atribuir socialmente determinados hechos constituye una afirmación extendida en los estudos de sociología de la organización que encuentra reconocimiento incluso en regulaciones jurídicas como la civil y la comercial. De esto se desprende que desde la perspectiva de las características del hecho y la organización colectiva no parecen presentarse objeciones de peso contra una imputación de comportamientos a la persona jurídica. Incluso tampoco hay mayor inconveniente para imputar directamente a la persona jurídica riesgos derivados de su ámbito de organización que resultan penalmente relevantes, pues de la esfera de organización de una persona jurídica pueden derivar sucesos defraudatorios de expectativas sociales esenciales, del mismo modo que de la esfera de organización de una persona natural. La dificultad no se encuentra, por tanto, en la imputación de un riesgo prohibido a la esfera de organización de la persona jurídica, sino en la capacidad de la persona jurídica para pode recibir una imputación personal.”. GARCÍA CAVERO, Percy. La persona..., p. 66-67.
} 
responsabilidade de tais entes se encontra em nosso país para, tendo determinado tal quadro, analisar as teorias relativas à tentativa de construção de uma culpabilidade (ou critério equivalente) própria da pessoa jurídica. 


\section{O TRATAMENTO JURÍDICO DA RESPONSABILIDADE DA PESSOA JURÍDICA NO BRASIL}

Conquanto o tema do presente trabalho enfoque a responsabilidade penal da pessoa jurídica, crê-se ser de suma importância a análise não só dos dispositivos constitucionais e legais brasileiros referidos a tal modalidade de responsabilização (ressaltando-se a Lei 9.605/98, que trouxe em seu artigo $3^{\circ}$ a previsão de responsabilidade penal das pessoas jurídicas nos crimes ambientais), como também da recente Lei 12.846/2013. A aludida lei, alinhando-se à temática internacional de combate à corrupção, previu a responsabilização da pessoa jurídica, limitada, contudo, às esferas civil e administrativa, deixando expresso o caráter objetivo de tal responsabilidade. Deve-se ter em conta, entretanto, que, ainda que de forma incipiente, tal lei parece trazer ao discurso nacional uma aproximação a considerações organizativas da empresa, apontado para a necessidade de maior compreensão de temas como a adoção de códigos de ética, gestão empresarial, entre outros, relacionados à auto-organização empresarial e, portanto, ainda que de forma indireta, às noções mais modernas de culpabilidade empresarial, como teremos oportunidade de analisar.

\subsection{A responsabilidade penal da pessoa jurídica no Brasil}

\subsubsection{A Constituição Federal de 1988 e os conflitos interpretativos em relação à responsabilidade penal da pessoa jurídica}

A Constituição Federal de 1988 trouxe em seu bojo o germe da ampliação dos debates sobre a responsabilidade penal da pessoa jurídica na doutrina brasileira, ao acrescer às discussões dogmáticas o argumento de caráter legislativo ${ }^{126}$. Dois articulados presentes no texto constitucional brasileiro (os artigos $173, \S 5^{\circ}$ e $225, \S 3^{\circ}$ ) são objetos, ainda hoje, de acaloradas discussões a respeito do albergo, por nosso legislador

\footnotetext{
${ }^{126}$ Ressalte-se que a inovação legislativa trazida pelo texto constitucional de 1988 não inaugurou os debates doutrinários acerca da responsabilidade penal da pessoa jurídica na doutrina brasileira. Já em 1930, AFFONSO ARINOS DE MELlo FRANCO publicou a obra "Responsabilidade criminal das pessôas jurídicas", aportando relevantes considerações sobre o tema ainda para a atualidade. Cf. FRANCO, Affonso Arinos de Mello. Responsabilidade criminal..., 1930.
} 
constituinte, da responsabilidade penal da pessoa jurídica. O art. $173, \S 5^{\circ}$ dispõe que "a lei, sem prejuízo da responsabilidade individual dos dirigentes da pessoa jurídica, estabelecerá a responsabilidade desta, sujeitando-a as punições compatíveis com sua natureza, nos atos praticados contra a ordem econômica e financeira e contra a economia popular". O art. $225, \S 3^{\circ}$, por sua vez, prevê que "as condutas e as atividades consideradas lesivas ao meio ambiente sujeitarão os infratores, pessoas físicas ou jurídicas, a sanções penais e administrativas, independentemente da obrigação de reparar os danos causados".

De início, pode-se afirmar que a falta de precisão redacional dos aludidos dispositivos permitiu que as discrepâncias já se dessem quanto a exegese gramatical de tais $\operatorname{textos}^{127}$, de forma que, apoiados em suas crenças dogmáticas, muitos autores refutam ter a nossa Lei Maior admitido a responsabilidade penal da pessoa jurídica.

Aqueles que assim entendem argumentam que o artigo $225, \S 3^{\circ}$, ao posicionar, na mesma sequência, os binômios "condutas e atividades", "pessoas físicas ou jurídicas" e "sanções penais e administrativas", determina uma relação posicional entre os termos. Assim, às pessoas físicas, que praticam condutas, caberiam sanções penais; já as pessoas jurídicas, no exercício de atividades (e não condutas) consideradas lesivas ao meio ambiente, seriam submetidas à sanções administrativas ${ }^{128}$. Afirma-se, ainda, que, ante a exigência contida no artigo $173, \S 5^{\circ}$, de compatibilidade das punições com a natureza da pessoa sancionada, seria impossível impor uma sanção penal à pessoa jurídica ${ }^{129}$.

Para alguns autores, aliás, a determinação interpretativa contida naquele articulado serviria como critério orientador da leitura do artigo $225, \S 3^{\circ}$, de tal forma que impediria reconhecer a responsabilidade penal de tais entes coletivos nesse dispositivo, como consequência de uma exegese de cunho sistemático do texto constitucional ${ }^{130}$.

Outro argumento, agora de cunho histórico, refutando a admissão da responsabilidade penal da pessoa jurídica em nossa Constituição, assevera que, na elaboração do texto constitucional do artigo 173 , $\S 5^{\circ}$, o legislador constituinte suprimiu da redação original o termo "criminal" contido no "responsabilidade desta", demonstrando, assim, a opção por não se albergar tal forma de responsabilização da pessoa jurídica, o que

\footnotetext{
${ }^{127}$ Sobre isso, afirma LuISI que o $\S 3^{\circ}$ do artigo 225 da Constituição Federal "tem ensejado uma discussão de matiz acentuadamente gramatical". LUISI, Luiz. Notas sobre..., p. 35.

${ }^{128}$ Nesse sentido, ver o capítulo "A constituição e a responsabilidade penal da pessoa jurídica" em: PIERANGELI, José Henrique. Escritos Jurídico-Penais, São Paulo: Revista dos Tribunais, 2006, p. 132-141. PRADO, Luiz Regis. Responsabilidade penal..., p.147. DOTTI, René Ariel. A incapacidade..., p. 164.

${ }^{129}$ BITTENCOURT, Cezar Roberto. Responsabilidade penal da pessoa jurídica à luz da Constituição Federal. Boletim IBCCRIM, n. 65, ed. esp., p. 7, abr. 1998; CERNICCHIARO, Luiz Vicente; COSTA JÚNIOR, Paulo José da. Direito Penal na Constituição. São Paulo: Revista dos Tribunais, 1995, p. 161.

${ }^{130} \mathrm{Cf}$. PRADO, Luiz Regis. Responsabilidade penal..., p. 147.
} 
serviria, numa leitura sistemática, para refutar, também, a admissão da responsabilidade penal dos entes coletivos no artigo $225, \S 3^{\circ}$, da Constituição Federal ${ }^{131}$.

Nega-se a responsabilidade penal da pessoa jurídica, ainda, empregando-se uma interpretação sistemática e principiológica do texto constitucional na sua integralidade. Nesse sentido, argumenta-se que adotar a responsabilidade penal da pessoa jurídica seria afrontar os princípios contidos na Constituição Federal relativos à individualização da pena (artigo $5^{\circ}$, XIII), pessoalidade da pena (artigo $5^{\circ}$, inciso XLV) e culpabilidade (artigo $5^{\circ}$, incisos XLVI e LVII) ${ }^{132}$.

Não faltam na doutrina brasileira, contudo, interpretações dos mencionados dispositivos constitucionais no sentido da admissão da responsabilidade penal da pessoa jurídica por nossa lei maior, mesmo entre autores que se manifestam avessos à admissão dessa forma de responsabilização criminal $^{133}$.

Nesse sentido, e retomando-se a exegese gramatical do texto constitucional, afirma-se que o $\S 3^{\circ}$ do artigo 225 conteria conjunção alternativa na fórmula "pessoas físicas ou jurídicas" e conjunção aditiva na formulação "sanções penais e administrativas", demonstrando-se, com isso, que não se excluiria a possibilidade de aplicação de nenhuma dessas reprimendas às pessoas, quer físicas, quer jurídicas ${ }^{134}$.

Para outros autores, entretanto, ao invés do apego à interpretações gramaticais, deve-se tentar extrair o significado semântico dos termos que seja "apropriado para a vida real, e conducente a uma justa apreciação doutrinária e legal”. Assim, sem buscar uma "precisão matemática em sentido vocabular", deve-se encarar a linguagem como "obra humana" 135 . Desse modo, entende-se que o termo atividade, como sinônimo de ação, não é exclusivo da pessoa jurídica, de forma que tanto estas, como as pessoas físicas, podem praticar atividades ou condutas suscetíveis de punição penal por lesionarem o meio ambiente $^{136}$, conclusão a que chegam, também, alguns doutrinadores que criticam a

\footnotetext{
${ }^{131}$ REALE JÚNIOR, Miguel. A responsabilidade penal da pessoa jurídica. In: PRADO, Luis Régis,. DOTTI, René Ariel (coord.). Responsabilidade penal da pessoa jurídica: Em defesa do princípio da imputação subjetiva. 2.ed. São Paulo: Revista dos Tribunais, 2010, p. 344, LUISI, Luiz. Notas sobre..., p. 35.

${ }^{132}$ LUISI, Luiz. Notas sobre..., p. 37-38.

${ }^{133}$ Nesse sentido: BASTOS, Celso Ribeiro; MARTINS, Ives Gandra. Comentário à Constituição do Brasil. São Paulo: Saraiva, 1990, p. 104-105. ZAFFARONI, Eugênio Raul; PIERANGELLI, José Henrique. op. cit., p. 409-411.

${ }^{134}$ FREITAS, Vladimir Passos de. O crime ambiental e a pessoa jurídica. Cidadania e Justiça, v. 3, n. 6, p. 213, jan.-jun.1999. Essa interpretação se assemelha a de NIETO MARTíN, para quem os princípios contidos na Constituição espanhola relacionados à culpabilidade seriam aplicáveis às pessoas naturais. NIETO MARTÍN, Adan. La responsabilidad penal..., p. 120.

${ }^{135}$ SHECAIRA, Sérgio Salomão. Responsabilidade penal..., p. 125-126.

${ }^{136}$ Id. Ibid., p. 126;
} 
redação constitucional, crendo haver uma superfetação na distinção entre os vocábulos "conduta" e "atividade"137.

Salientam, ainda, que a adoção da responsabilidade dos entes coletivos não representaria uma afronta a princípios também contidos no texto constitucional, mas a formulação de uma modalidade especial de responsabilização penal, diversa da voltada para a conduta individual ${ }^{138}$.

\subsubsection{A lei $9.605 / 98$ e a responsabilidade penal da pessoa jurídica}

A lei 9.605/98 trouxe a previsão, em seu artigo $3^{\text {o139 }}$, da responsabilidade penal da pessoa jurídica, segundo a interpretação majoritária da doutrina brasileira ${ }^{140}$, na exclusiva seara da tutela ambiental, concretizando, por lei ordinária, o disposto no artigo $225, \S 3^{\circ}$, da Constituição Federal. Essa previsão normativa, contudo, ressentiu-se de falhas técnicas contidas no texto legislativo que dificultaram sua efetiva aplicação às pessoas jurídicas e que, para alguns autores, expressam a mera enunciação dessa nova modalidade de responsabilidade penal, sem sua efetiva instituição ${ }^{141}$. Percebe-se, em verdade, mesmo entre os defensores da responsabilidade penal da pessoa jurídica, um tom crítica na análise de tal lei, pelas inconsistências trazidas em seu bojo.

Consigna-se, também, que não apenas a falta de elementos para conformar esse novo "microssistema de responsabilidade penal", mas a ausência de regras processuais específicas, impedem a aplicação concreta da referida lei no que atine à responsabilização

\footnotetext{
${ }^{137}$ CERNICHIARO, Luiz Vicente; COSTA JUNIOR, Paulo José. op. cit., p. 262.

${ }^{138}$ FREITAS, Vladimir Passos de. op. cit., p. 213.

${ }^{139}$ Dispõe o mencionado articulado: “As pessoas jurídicas serão responsabilizadas administrativa, civil e penalmente conforme o disposto nesta lei, nos casos em que a infração seja cometida por decisão de seu representante legal ou contratual, ou de seu órgão colegiado, no interesse ou no benefício da sua entidade. Parágrafo único: a responsabilidade das pessoas jurídicas não exclui a das pessoas físicas, autoras, co-autoras ou partícipes do mesmo fato".

${ }^{140}$ Para PITOMBO, contudo, deve-se interpretar de forma diversa tal dispositivo, não havendo nele verdadeira previsão de reprovação penal à pessoa jurídica. Consigna o autor: "É hora de se reconhecer que o sentido da reprovação da pessoa jurídica nada tem de direito penal. A previsão do artigo $3^{\circ}$, da Lei $9.605 / 98$ constitui permissivo ao juiz penal para a aplicação de sanção de cunho administrativo à pessoa jurídica.”. PITOMBO, Antonio Sergio Altieri de Moraes. Denúncia em face da pessoa jurídica, na perspectiva do direito brasileiro. In: PRADO, Luiz Regis; DOTTI, René Ariel (coord.). Responsabilidade penal da pessoa jurídica: Em defesa do princípio da imputação subjetiva. 2.ed. São Paulo: Revista dos Tribunais, 2010, p. 235. Nesse sentido, também: MARQUES, Oswaldo Henrique Duek. A responsabilidade da pessoa jurídica por ofensa ao meio ambiente. Boletim IBCCRIM, n. 65, ed. esp., p.6, abr. 1998.

${ }^{141}$ ROBALDO, José Carlos de Oliveira. A responsabilidade penal da pessoa jurídica: direito penal na contramão da história. In: GOMES, Luiz Flávio. Responsabilidade Penal da Pessoa Jurídica e Medidas Provisórias de Direito Penal, São Paulo: RT, 1999, p. 98. REGIS PRADO, Luiz. Responsabilidade penal..., p. 149
} 
penal dos entes coletivos ${ }^{142}$, o que deveria ser solucionado, para alguns, com a edição de lei específica sobre o tema para alterar ou acrescer dispositivos ao Código de Processo Penal $^{143}$, e, para outros, com a aplicação imediata dos dispositivos do Código de Processo Penal e de Processo Civil ${ }^{144}$.

\subsubsection{O modelo de responsabilidade penal adotado}

A leitura do artigo $3^{\circ}$ da Lei 9.605/98 revela que a imputação de uma prática delitiva à pessoa jurídica dependerá da identificação da conduta de certos agentes específicos e com determinada finalidade. Esclarecendo, dispõe o referido articulado que somente nas infrações resultantes das decisões do "representante legal ou contratual" da empresa ou de "seu órgão colegiado", decisões estas tomadas no interesse ou para o benefício do ente coletivo, é que se poderá responsabilizá-lo criminalmente.

Conquanto seja assim, e que a orientação legislativa pareça revelar a adoção da teoria da identificação ou do alter ego, em que há a dependência da manifestação dos órgãos diretivos ou representativos para que possa haver a imputação de conduta ilícita à pessoa jurídica, esta opção não se fez de modo excludente. Em outras palavras, e talvez melhor esclarecendo, o próprio artigo $3^{\circ}$, em seu parágrafo único, estabelece que "a responsabilidade da pessoa jurídica não exclui a das pessoas físicas, autoras, coautoras ou partícipes do mesmo fato".

Esse modelo, denominado também como "sistema de dupla imputação"145, permite que a persecução penal se dê em face de ambos os agentes delitivos (pessoas físicas e jurídicas), exigindo a constatação de um comportamento humano ${ }^{146}$, mas determinando que não haja a exclusão da imputação a qualquer participante em face da responsabilização do outro.

Defende-se, ainda, que não há em tal modelo a admissão de um bis in idem, posto que, além de pessoas distintas a serem responsabilizadas, cada uma terá punição

\footnotetext{
${ }^{142}$ PRADO, Luiz Regis. Responsabilidade penal..., p. 149.

${ }^{143}$ SHECAIRA, Sérgio Salomão. A responsabilidade das pessoas jurídicas e os delitos ambientais. Boletim IBCCRIM, n. 65, ed. esp. p. 2, abr.1998.

${ }^{144}$ SICOLI, José Carlos Meloni. A tutela penal do meio ambiente na lei n. 9.605, de 13 de fevereiro de 1998. Boletim IBCCRIM, n. 65, ed. esp., p. 1-13, abr. 1998.

${ }^{145}$ SHECAIRA, Sergio Salomão. Responsabilidade..., p. 138.

${ }^{146}$ Para REGIS PRADO, aproxima-se o modelo brasileiro do sistema francês. PRADO, Luiz Regis. Responsabilidade penal..., p. 144.
} 
ponderada consoante sua contribuição para a prática delitivas ${ }^{147}$.

Impõe-se consignar, contudo, que há, na doutrina brasileira, autores que veem nesse modelo de imputação a "crise da teoria e da prática do concurso de pessoas" ${ }^{148}$, na medida em que, por exemplo, não se poderia vislumbrar uma vontade comum entre pessoa física e jurídica, circunstância inerente à concorrência, e assim desvendar a divisão de tarefas e suas peculiaridades, ou mesmo soaria incongruente apurar-se uma coautoria entre ente moral e indivíduo humano ${ }^{149}$. Tais argumentos, contudo, são também rebatidos na doutrina, para aqueles que enxergam nessa relação de dupla imputação entre pessoa física e jurídica uma "coautoria necessária" em que a pessoa jurídica será "autora mediata", devendo esta ter o "domínio do fato" para que se admita sua responsabilização, requisito que afastaria, desde logo, indagações sobre a participação, inclusive de menor importância, ou a instigação pela empresa ${ }^{150}$.

Para outros autores, entretanto, nem sequer há um modelo de responsabilização penal da pessoa jurídica previsto nesse dispositivo, mas apenas um "permissivo ao juiz penal para a aplicação de sanção de cunho administrativo à pessoa jurídica" ${ }^{\circledR 1}$, de forma que o que se exige no articulado é a apuração de uma relação de causalidade entre a decisão do representante legal, contratual ou órgão colegiado e a infração penal. Assim, falar-se na previsão, pela lei 9.605/98, de uma responsabilização por reflexo ou ricochete da pessoa jurídica (tal como designada a responsabilidade da pessoa moral no modelo francês) seria uma impropriedade, pois a ocorrência da infração penal não torna automática a responsabilidade da pessoa jurídica, dependendo da apuração da mencionada relação de causalidade, que será difícil de observar nos delitos omissivos e culposos ${ }^{152}$.

Não se pode olvidar, ainda, aqueles que enxergam no modelo de responsabilidade penal da pessoa jurídica implantado pela Lei 9.605/98 verdadeira responsabilidade objetiva, propugnando pela "superação do paradigma clássico do direito penal" nesse campo fértil que é o Direito penal ambiental ${ }^{153}$.

\subsubsection{A problemática das penas}

\footnotetext{
${ }^{147}$ SHECAIRA, Sergio Salomão. Responsabilidade..., p. 139.

${ }^{148}$ Nesse sentido, DOTTI, René Ariel. A incapacidade..., p. 172.

${ }^{149}$ Id. Ibid., p. 172-173.

${ }^{150}$ SHECAIRA, Sérgio Salomão. Responsabilidade..., p. 168-169.

${ }^{151}$ PITOMBO, Antonio Sergio Altieri de Moraes. Denúncia em face..., p. 235.

${ }^{152}$ Id. Ibid., p. 236-237.

${ }^{153}$ TANGERINO, Davi de Paiva Costa. A responsabilidade penal da pessoa jurídica para além da velha questão de sua constitucionalidade. Boletim IBCCRIM, n. 214, p. 18, set. 2010.
} 
Nesse ponto é reconhecido o grande entrave à efetiva aplicação da responsabilidade penal da pessoa jurídica na Lei 9.605/98.

Compulsando-se o referido texto legal, verifica-se que as sanções penais às pessoas jurídicas encontram-se previstas nos artigos 21 a 24, afrontando, assim, a tradição jurídico-penal brasileira de estabelecer as sanções penais nos preceitos secundários dos tipos penais. Nos mencionados dispositivos, reconheceu-se como penas passíveis de serem aplicadas aos entes coletivos, de forma isolada, cumulativa ou alternativa, a multa, penas restritivas de direito (suspensão parcial ou total de atividades; interdição temporária de estabelecimento, obra ou atividade; proibição de contratar com o Poder Público, bem como dele obter subsídios, subvenções ou doações) e prestação de serviços à comunidade.

Desde logo, deve-se apontar um rompimento com a sistemática do Código Penal, posto que a prestação de serviços constitui, segundo a disciplina do artigo 43, inciso IV, uma espécie de restitiva de direitos, conquanto não prevista entre estas. De igual modo, entre as penas de prestação de serviços, elenca-se sanções com nítido cunho pecuniário, efetuando-se verdadeira confusão entre a natureza de tais reprimendas ${ }^{154}$.

Além da impropriedade técnica contida na Lei 9.605/98, o grande defeito apontado pela doutrina brasileira é a ausência de um paradigma para a aplicação de tais sanções ${ }^{155}$. Observe-se que, em não havendo a previsão, nos tipos legais, das penas a serem aplicadas, em cada caso, à pessoa jurídica, muito menos uma previsão genérica concreta a estabelecer critérios de integração entre as sanções destinadas às pessoas jurídicas com aquelas penas abstratamente cominadas à pessoa física, inexiste parâmetro, quer quantitativo, quer qualitativo, à determinação das reprimendas. Parece obviedade dizer, também, que diante desta inexistência de previsão de sanções aos entes coletivos no tipo penal, descabe cogitar da aplicação "alternativa" de tais penas, na medida em que não existe outra opção sancionatória para que as reprimendas contidas no artigo 21 a 24 sejam consideradas uma "alternativa".

Diante de tais considerações, e constatada a deficiência da Lei Ambiental, a determinação das sanções penais - não apenas com relação ao seu dimensionamento, mas

\footnotetext{
${ }^{154}$ Nesse sentido: LUISI, Luiz. Notas sobre..., p. 40. SHECAIRA, Sergio Salomão. Responsabilidade..., p. 150.

${ }^{155}$ Nesse sentido: LUISI, Luiz. Notas sobre..., p. 40-42; PRADO, Luiz Regis. Responsabilidade penal..., p. 151-154; SANTOS, Juarez Cirino. Responsabilidade penal..., p. 274-276; BREDA, Juliano. Inconstitucionalidade..., p. 289; SHECAIRA, Sérgio Salomão. Responsabilidade..., p. 149-154. SIRVINSKAS, Luís Paulo. Questões polêmicas sobre a responsabilidade penal da pessoa jurídica nos crimes ambientais. Boletim IBCCRIM, n. 65, ed. esp., p.8, abr. 1998.
} 
também na escolha de certa modalidade sancionatória a ser aplicada em face de determinada conduta delitiva - acabará ficando ao alvedrio do julgador, algo inaceitável diante do princípio da legalidade consagrado no artigo 5º inciso XXXIX, da Constituição Federal, conclusão esta que a doutrina brasileira parece acatar com certa uniformidade.

\subsection{A Lei 12.846/2013 e a responsabilização administrativa e civil de pessoas jurídicas pela prática de atos contra a administração pública}

A Lei 12.846/2013 é reflexo do compromisso brasileiro com a agenda internacional no tema do combate à corrupção ${ }^{156}$. Em especial, concretiza o compromisso assumido com a ratificação da "Convenção Internacional sobre o Combate da Corrupção de Funcionários Públicos Estrangeiros em Transações Internacionais” da Organização para a Cooperação Econômica e o Desenvolvimento (OCDE).

A aludida Convenção demonstra, em seu preâmbulo, os objetivos da cooperação internacional no combate à corrupção. Ressalta as consequências não só políticas e morais do fenômeno, mas também econômicas, por abalar as condições internacionais de competitividade; põe em relevo a necessidade de cooperação, monitoramento e acompanhamento multilaterais; e consagra um aspecto que parece de extrema importância em relação à responsabilização da pessoa jurídica: a busca pela obtenção de equivalência entre as medidas a serem tomadas pelas partes. Aliás, deixa claro que, em busca dessa uniformidade, por assim dizer, deve haver a ratificação da Convenção sem derrogações que afetem a mencionada equivalência. ${ }^{157}$

Nesse aspecto, salta aos olhos, muito mais do que a definição dos delitos de corrupção no artigo 1 da Convenção, a previsão, no artigo 2, de que cada Parte tome as medidas necessárias ao estabelecimento das responsabilidades de pessoas jurídicas pela corrupção de funcionário público estrangeiro ${ }^{158}$.

É bem verdade, e não se descura, que ao tratar da responsabilidade de pessoas jurídicas, a Convenção não opta expressamente por determinada natureza de

\footnotetext{
${ }^{156}$ São eles: Convenção das Nações Unidas contra a Corrupção (Convenção da ONU); Convenção Interamericana contra a Corrupção (Convenção da OEA) e Convenção sobre o Combate da Corrupção de Funcionários Públicos Estrangeiros em Transações Comerciais Internacionais (Convenção da OCDE).

${ }^{157}$ Dispõe a Convenção em seu preâmbulo: “[...] a obtenção de equivalência entre as medidas a serem tomadas pelas Partes é o objeto e o propósito essenciais da presente Convenção, o que exige a sua ratificação sem derrogações que afetem essa equivalência.".

${ }^{158}$ Prevê o artigo 2, sob a rubrica "Responsabilidade de Pessoas Jurídicas": "Cada Parte deverá tomar as medidas necessárias ao estabelecimento das responsabilidades de pessoas jurídicas pela corrupção de funcionário público estrangeiro, de acordo com seus princípios jurídicos.".
} 
responsabilização (se criminal, administrativa ou civil). Aliás, deixa claro que tal responsabilibilidade deverá ser adotada de acordo com os princípios jurídicos de cada Estado que venha a ratificar a Convenção. Desse modo, o legislador brasileiro, ao editar a Lei 12.846/2013, optou por uma responsabilidade de natureza administrativa e civil das pessoas jurídica, fugindo da problematização que a admissão de uma responsabilidade penal poderia trazer.

E, se assim o foi, não estaria a mencionada lei a rechaçar o debate objeto do presente trabalho? Não se estaria demonstrando que, a despeito da discutida previsão constitucional e da Lei de Crimes Ambientais, de dificílima aplicação, a responsabilidade penal da pessoa jurídica (e, portanto, o debate sobre a eventual construção de uma culpabilidade desse ente coletivo), pelo menos no âmbito nacional, não seria mais do que elucubração teórica sem aplicação, superada pelo que a práxis legislativa brasileira vem demonstrando? Em verdade, pensa-se que a análise acurada da Lei 12.846 vem apontar em sentido contrário. Isto porque, conquanto trate especificamente da responsabilidade administrativa e civil da pessoa jurídica, a referida lei traz aspectos importantes relacionados à discussão internacional sobre a responsabilidade penal e, consequentemente, à culpabilidade desses entes coletivos.

Em primeiro lugar, é importante perceber que a lei faz uma importante definição sobre o âmbito de abrangência do termo "pessoa jurídica". Segundo a regra contida na Lei 12.846, as responsabilidades civil e administrativa nela previstas seriam aplicáveis não só às sociedades personificadas, mas também àquelas constituídas apenas de fato, ainda que temporárias. Abrange, assim, as sociedades empresárias (personificadas ou não), sociedades simples (personificadas ou não), fundações, associações (de entidades ou pessoas) e sociedades estrangeiras, demonstrando, dessa forma, que na responsabilização, o termo pessoa jurídica deve ser tomado de forma mais ampla, fugindo de seu conceito civilista, mesmo quando se trate de responsabilidade civil. Traz, assim, uma orientação interpretativa a ser seguida, ao que se pensa, também no campo de abrangência da responsabilidade penal da pessoa jurídica.

Especial significação, todavia, parece revelar a previsão da influência da organização empresarial sobre o dimensionamento da responsabilidade, consagrando-se, aí, aspecto de fundamental relevo, como se verá, nas construções teóricas de culpabilidade da pessoa jurídica. Note-se que a Lei 12.846/03, em seu artigo $7^{\circ}$, inciso VIII, dispõe que será levada em consideração na aplicação das sanções "a existência de mecanismos e 
procedimentos internos de integridade, auditoria e incentivo à denúncia de irregularidades e a aplicação efetiva de códigos de ética e de conduta no âmbito da pessoa jurídica”.

A leitura do aludido articulado permite concluir que o legislador pátrio, não alheio ao tratamento legislativo e doutrinário estrangeiro no tema da responsabilidade da pessoa jurídica, trouxe previsão expressa da influência da adoção de modelos de gestão, de auto-organização empresarial ou programas de compliance sobre o dimensionamento das sanções a serem impostas aos entes coletivos. Ainda que sem definição sobre parâmetros de avaliação desses mecanismos e procedimentos, nem mesmo quanto ao dimensionamento de suas consequências sobre as sanções, reconhece que a adoção de certos procedimentos internos voltados não apenas para uma organização e desenvolvimento da atividade empresarial em conformidade com o direito (aspecto, portanto, pré-delitivo), mas também ponderando comportamentos pós-delitivos, como o incentivo à denúncia de irregularidades, devem ser considerados para atenuar a responsabilidade da pessoa jurídica.

Revela-se, com isso, a adoção de uma estratégia de "autorregulação empresarial", estimulando a interação funcional entre o sistema regulador estatal e os sistemas reguladores privados. Recorre o Estado, dessa forma, a uma estratégia regulatória diferenciada, valendo-se das próprias empresas para lograr seus objetivos ${ }^{159}$.

É bem verdade, como já se disse, que essa previsão ainda não se encontra adequadamente delineada na referida lei. Por mais que se possa apurar, pela própria redação do artigo $7^{\circ}$, inciso VIII, consideração de aspectos não só pré-delitivos, como também pós-delitivo, não há a concreta definição de um conteúdo mínimo desses mecanismos e procedimentos, muito menos de parâmetros para sua valoração e efetiva influência sobre a sanção.

Deve-se ter em mente, contudo, que tal previsão trouxe, para o específico âmbito da responsabilidade da pessoa jurídica, a discussão sobre a avaliação da dimensão organizativa da empresa como forma de se apurar a medida dessa responsabilização. Não se olvida, é bem verdade, que o legislador pátrio fora expresso em adotar uma responsabilidade administrativa e civil objetiva da pessoa jurídica, estratégia criticável, sobretudo no primeiro âmbito de responsabilização mencionado, onde, ao que se pensa, o

\footnotetext{
${ }^{159}$ Nesse sentido, afirma IVÓ COCA que : “[...] a autorregulação não responderia a um impulso desregulador, mas, ao contrário, suporia uma melhoraria quantitativa e qualitativa na intervenção estatal. COCA VILA, Ivó. ¿Programas de cumplimiento..., p. 46.
} 
princípio da culpabilidade vigora ${ }^{160}$. E, dentro de uma lógica de responsabilidade objetiva, é evidente que essa apuração da organização empresarial não tem qualquer influência sobre questões de culpabilidade, na medida em que esta nem sequer é cogitada.

Todavia, não se pode deixar de notar que, quer por uma crítica à adoção de uma responsabilidade objetiva, quer porque, na prática, ao se levar em conta aspectos da organização empresarial, da existência de códigos de ética, ou mesmo de incentivo a denúncias de irregularidades, está-se, a bem da verdade, determinando um critério para avaliar a influência do "comportamento organizativo empresarial" na prática delitiva, o que se tem é uma referência para se distinguir níveis de responsabilidade da empresa sobre o comportamento delitivo que se revela em seu bojo. Com isso, a despeito de sua responsabilidade objetiva, parece que o legislador abriu espaço para se questionar, por exemplo, se é possível exigir uma dimensão organizativa da empresa; se é possível, com essa organização, apurar e evitar riscos; se há uma expectativa social da adoção dessa organização; se há um dever da pessoa jurídica de institucionalizar certa ética social; se houve a opção da pessoa jurídica de não se organizar ou de adotar uma ética indevida, permitindo a prática delitiva, ou, em outros termos, se optou por uma "infidelidade ao direito"; e, até mesmo, se adotou comportamento reativo ao delito manifestado em seu bojo.

Enfim, por mais que a Lei 12.846/03 fale, expressamente, de uma responsabilidade administrativa e civil objetiva, traz em seu bojo a consideração de

\footnotetext{
${ }^{160}$ Nesse sentido, concordamos com Silvina BACIGALUPO, para quem: "Indepedientemente del sistema de responsabilidade por el que se opte, lo que debe quedar claro es que no cabe la aplicación de ninguna sanción, ya sea penal o administrativa, sin la determinación de culpabilidad de las personas jurídicas.". BACIGALUPO, Silvina. La responsabilidad penal de las personas jurídicas. Barcelona: Bosch, 1998, p. 399. Aliás, esse é um argumento, segundo a autora, para que não se rechasse a responsabilidade penal da pessoa jurídica. Afirma ela: "La doctrina y jurisprudência majoritária sostienen que los princípios rectores del derecho sancionador $\mathrm{y}$, por tanto, los princípios de imputación, ya sea por resposanbilidade penal o administrativa, no son diversos: en ambos casos se requiere la concurrencia de la comisión de un ilícito (típico y antijurídico) y la culpabilidade del autor para poder imponer una sanción. Consecuentemente, admitida la posibilidad de sancionar las personas jurídicas en el derecho administrativo sancionador, no existen verdadeiros impedimentos dogmáticos para negar su responsabilidad penal.”. BACIGALUPO, Silvina. Los criterios de imputación de la responsabilidad penal de las empresas y de sus órganos de gobierno y la relevância de los programas de compliance en el código penal español (artículos 31 bis y $129 \mathrm{CP}$ ). Revista de Estudos Criminais, ano X, n. 42, p. 13, jul.-sept. 2011. Posição diversa tem BAJO FerNÁNDEZ, para quem, por mais que a jurisprudência constitucional espanhola tenha reconhecido a aplicação dos princípios orientadores do Direito Penal ao Direito Administrativo Sancionador, ressalta que há uma matização, devendo-se respeitar as peculiaridades do processo administrativo. Conclui o autor, então, que: "Una de tales peculiaridades, es por lo que se refiere al tema que aqui nos ha traído, la responsabilidad penal de las personas jurídicas que no puede fundamentarse en la culpabilidad del infractor.". BAJO FERNÁNDEZ, Miguel. La responsabilidad penal de las personas jurídicas en el derecho administrativo español. In: MIR PUIG, Santiago; LUZÓN PEÑA, Diego Manuel (coord.). La responsabilidad penal de las empresas y sus órganos y responsabilidad por el producto. Barcelona: J.M. Bosch, 1996, p. 30.
} 
aspectos da pessoa jurídica vinculados às construções teóricas de uma culpabilidade empresarial, demonstrando, portanto, que o debate não sucumbiu às rotulações legais. 


\section{EVOLUÇÃO TEÓRICA DA CULPABILIDADE INDIVIDUAL}

\subsection{Introdução ao problema da culpabilidade}

Para se cogitar sobre a possível construção de um conceito de culpabilidade para a pessoa jurídica (ou mesmo sobre um equivalente funcional), deve-se ter bem presente as dificuldades e impasses que o conceito de culpabilidade ainda no estrito campo da pessoa física enfrenta. Afinal, seria impossível ter-se presente as objeções apontadas pela doutrina para a construção de uma culpabilidade da pessoa jurídica sem se ter em conta a função e o conteúdo desse conceito em sua origem individual.

Nesse sentido, é importante consignar que o desenvolvimento de um conceito de culpabilidade não se deu num percurso evolutivo linear e, ainda hoje, não alcançou um resultado unívoco em sua determinação, isso ainda pensando no estrito campo de uma culpabilidade individual.

Por mais que não se possa precisar com exatidão um momento histórico de seu surgimento, certo é que a introdução de elementos anímicos na ideia de crime ${ }^{161}$, questionando-se a evitabilidade do fato, entendida como um aspecto peculiar ao agir humano, permitiu a construção conceitual da culpabilidade. Contudo, seu desenvolvimento como conceito autônomo com posição sistemática na teoria do delito teria se dado com VON LISZT, que passa a distinguir a antijuridicidade e a culpabilidade como elementos do crime, permitindo-se, a partir daí, o desenvolvimento de diversas teorias sobre esta última.

Essa evolução teórica passa por concepções como a teoria psicológica da culpabilidade que, apoiada na busca de dotar os conceitos jurídicos de dados empiricamente comprováveis ${ }^{162}$, permitiu a cisão da face natural e formal do delito da sua parte psicológica que se manifestava na culpabilidade ${ }^{163}$, entendendo-a, assim, como

\footnotetext{
${ }^{161}$ Assim afirma FRANCISCO DE ASSIS TOLEDO: "Não se pode apontar com exatidão o momento histórico em que tal fenômeno ocorreu, mesmo porque a história do direito penal está marcada de retrocessos. Fora de dúvida, porém, é que, a partir de então, se começa a construir a nossa de culpabilidade, com a introdução, na ideia de crime, de alguns elementos psíquicos, ou anímicos - a previsibilidade e a voluntariedade - como condição de aplicação da pena criminal - nullum crimen sine culpa.”. TOLEDO, Francisco de Assis. Princípios básicos de Direito Penal. 5. ed. São Paulo: Saraiva, 2001, p. 219.

${ }^{162}$ Afirma JAKOBS que "esta solución surgió como consecuencia de la consideración naturalística, pero también del afán, orientado al Derecho público, de expulsar valoraciones imprecisas fuera del concepto de culpabilidad y de sujetar la culpabilidad a datos verificables con seguridad". JAKOBS, Günther. Derecho Penal: Parte General. Fundamentos y teoria de la imputación. 2. ed. Trad. Joaquin Cuello Contrera e José Luis Serrano Gonzales de Murillo. Madrid: Marcial Pons, 1997, p. 568-569.

${ }^{163}$ Afirma MIR PUIG: "O 'ambiente positivista' do final do século passado plasmou-se em uma construção da teoria do delito que, por um lado, partia da divisão do crime em duas partes que se revelavam separadas ante
} 
vínculo psicológico entre o agente e o fato - ou seja, como possibilidade de conhecimento, pelo agente, do fato -, concepção esta criticada por sua incapacidade teórica de determinar os fatos psíquicos relevantes para a verificação da culpabilidade ${ }^{164} \mathrm{e}$, bem por isso, não conseguindo solucionar questionamentos sobre a culpa consciente e o estado de necessidade exculpante.

Buscando superar essa formulação teórica, desenvolveu-se a concepção normativa da culpabilidade, entendendo-a não como mera vinculação psíquica, mas como uma "culpabilidade psicológico-normativa", ou seja, como reprovação por uma vontade valorada como defeituosa. Como afirmou BetTIOL, o crime deixa de ser apenas uma constatação, passando a ser "fruto de uma valoração"165. Insere-se na culpabilidade um elemento normativo, por obra de FRANK, permitindo a ela englobar também a culpa inconsciente. Esse elemento - a possibilidade de atuar de maneira diversa - transformou a culpabilidade num juízo normativo de valor (reprovabilidade) ${ }^{166}$, mas foi nele, também, em que se apoiaram as críticas a essa construção teórica, fundadas, essencialmente, na impossibilidade de demonstração pragmática desta "possibilidade" ou "exigibilidade" de se atuar de forma diversa, ou seja, na indemonstrabilidade de que "a escolha na conduta não sofreu variações circunstanciais que modificaram a vontade" 167.

Procurando-se superar esta concepção normativista, há construções teóricas indicadas como "pré-finalistas", como as ideias de GRAF ZU DOHNA, que entende a culpabilidade como valoração do dolo, seu objeto ${ }^{168}$, traduzindo-a como determinação da

a percepção dos sentidos: a parte externa e a parte interna. Por outro lado, considerava como elemento definidor fundamental a ideia de causalidade. A parte externa do fato identificava-se com o objeto da antijuridicidade, enquanto a parte interna referia-se à culpabilidade. Esta se apresente como o conjunto de elementos subjetivos do fato". MIR PUIG, Santiago. Direito penal: fundamentos e teoría do delito. Trad. José Carlos Nobre Porciúncula Neto. São Paulo: Revista dos Tribunais, 2007, p. 410.

${ }^{164}$ JAKOBS, Günther. Derecho Penal..., p. 569.

${ }^{165}$ BETTIOL, Giuseppe. O problema penal. Trad. Fernando de Miranda. Coimbra: Coimbra Ed., 1967, p. 150.

${ }^{166}$ Segundo MIR PUIG: “A concepção normativa de culpabilidade surgiu em um contexto cultural de superação do naturalismo positivista e de sua substituição pela 'metodologia neokantiana', própria do chamado 'conceito neoclássico de delito'. Já não se tratava de descrever realidades naturalísticas, externas ou internas, mas de compreender o significado valorativo dos conceitos jurídicos: a culpabilidade deixa de ser considerada com um "fato psíquico" e passa a ser entendida como um juízo de valor.". MIR PUIG, Santiago. Direito penal..., p. 413. Para JAKOBS, no entanto, "este (así llamado) concepto normativo de culpabilidad no es más, en su configuración inicial, que una mera ampliación de la relación, elaborada por Radbruch, entre hecho y desprobación jurídica (Radbruch: actitude antisocial; Frank: reprochabilidad), con la salvedad de que Frank abandona la limitación a dolo e imprudencia”. JAKOBS, Günther. Derecho Penal...., p. 570.

${ }^{167}$ CHAVES CAMARGO, Antonio Luis. Culpabilidade..., p. 121.

${ }^{168}$ Nesse sentido: WELZEL, Hans. El nuevo sistema del derecho pena: una introducción a la doctrina de la acción finalista. Trad. José Cerezo Mir. Barcelona: Ariel, 1964, p. 83. 
vontade contrária ao dever ${ }^{169}$, permitindo, com suas constatações, que se abrisse espaço para que, posteriormente, a concepção finalista remodelasse a teoria geral do delito.

Este remodelamento indicado como produto do finalismo caracteriza-se pela reformulação do conteúdo dos elementos componentes da estrutura do delito. Por meio do reconhecimento de que a ação humana não era dotada apenas de uma relação causal entre conduta e resultado, mas de um agir finalístico, pautado por suas opções, vislumbra-se um "fundamento ontológico da teoria da ação" ${ }^{170}$. Com isso, readequa-se a estrutura do crime, transpondo-se o dolo e a culpa para a própria tipicidade, retirando-os da culpabilidade, que passa a albergar em seu bojo um conteúdo estritamente normativo, englobando e tornando seu cerne a consciência da ilicitude ${ }^{171}$. Como consigna ChAves CAMARgo, a nova composição da culpabilidade, formada, agora, pela imputabilidade, potencial consciência da ilicitude e inexistência de causa de exculpação (esta última, elemento negativo da culpabilidade), evidenciam uma preocupação com a "possibilidade de estruturação de uma vontade responsável de acordo com a norma" ${ }^{, 172}$, ou seja, com o próprio livre-arbítrio, entendido como a possibilidade do homem, por meio da inteligência que é inerente à condição humana (e que se diferencia das atitudes instintivas) de comportar-se livremente consoante o valor, para o bem ou para o mal.

A grande crítica que se dirige à construção finalista de culpabilidade reside, contudo, na incapacidade de demonstração empírica do livre-arbítrio ${ }^{173}$ e, consequentemente, do núcleo central dessa reformulada culpabilidade, que se funda no poder agir de outro modo, crítica essa não superada por outras formulações teóricas que pretenderam trazer alternativas conceituais ainda apoiadas nessa orientação caracterizada como finalista ${ }^{174}$.

\footnotetext{
${ }^{169}$ DOHNA, Alexander Graf zu. La estructura de la teoria del delito. Trad. Carlos Fontán Balestra e Eduardo Friker. Buenos Aires: Abedelo-Perrot, 1958, p. 18-19. Ver, também, MACHADO, Fabio Guedes de Paula. Culpabilidade no direito penal. São Paulo: Quartier Latin, 2010, p. 69-70.

${ }^{170}$ MACHADO, Fabio Guedes de Paula. Culpabilidade..., p. 72.

${ }^{171}$ Welzel, tido como o pai dessa concepção finalista, afirma que esta reestruturação dogmática não provocou o esvaziamento da culpabilidade, mas, em verdade, sua depuração de elementos estranhos. WELZEL, Hans. op. cit., p. 84.

${ }^{172}$ CHAVES CAMARGO, Antonio Luis. Culpabilidade..., p. 123

${ }^{173}$ Criticando a presunção indemonstrável do livre-arbítrio ver: SCHÜNEMANN, Bernd. La culpabilidad: estado de la cuestión. Trad. David Felip I Saborit y Ramón Ragués I Vallés. In: ROXIN, Claus. et al. Sobre el estado de la teoría del delito: Seminario en la Universitat Pompeu Fabra. Madrid: Civitas, 2000, p. 95 e 105.

${ }^{174}$ Apenas para exemplificar, alternativas conceituais, ainda no campo da teoria finalista, foram trazidas por WERNER NIESE, KARL ENGISCH (sobre isso, ver: QUINTANO RIPPOLLÉS, Antonio. Hacia una posible concepción unitária jurídico-penal de la culpabilidad. Anuario de Derecho Penal. tomo XII, fasc. II. Madrid: Ministerio da Justicia, Boletín Oficial del Estado, p. 496, 1950.), ARTHUR KAUFFMAN (ver: MACHADO, Fabio Guedes. Culpabilidade..., p. 84) WILlHelm GALlAS (GALLAS, Wilhelm. La teoria do delito en su
} 
Contudo, como se disse, o desenvolvimento da ideia de culpabilidade não foi um percurso evolutivo linear. Tanto assim que a busca por se solucionar as críticas construídas culminaram, por vezes, na revisitação de concepções pretéritas, como a culpabilidade neoclássica e finalista. Nesse sentido, pode-se apontar as construções de autores como CoBo DEL Rosal e Vives Anton, ou mesmo de Luigi FerRAJOli, os primeiros reassumindo o dolo e a culpa não como objeto de valoração da culpabilidade, mas como formas constitutivas desse juízo e, por conseguinte, de atribuição dessa culpabilidade $^{175}$, e o segundo reafirmando a natureza subjetiva da culpabilidade, voltando a valoração para a relação psicológica entre o agente e a conduta criminosa ${ }^{176}$. Já em relação às concepções finalistas, as novas formulações assentadas nessa teoria, ainda entendendo a culpabilidade como fundamento e limite da pena, diferenciam-se ao buscar fundar a reprovação dirigida ao autor em sua motivação contrária à norma, e não em sua personalidade ou caráter, bem como por tentar definir empiricamente o conteúdo da culpabilidade. Assim afirmam, por exemplo, CEREZO MIR ${ }^{177}$ e GÜNTHER STRATENWERTH $^{178}$. Contudo, não superam completamente o dilema da indefinição do substrato desse elemento do crime, na medida em que ainda partem da concepção do homem como ser capaz de autodeterminação, trabalhando com o raciocínio negativo, de que essa presunção será superada, e se afastará a culpabilidade, quando se demonstra que não era possível agir de outro modo ${ }^{179}$.

Parece-nos, contudo, que é a concepção de culpabilidade no funcionalismo que tem dado o maior substrato para as construções que buscam hoje reformular o conceito de culpabilidade para adaptá-lo à responsabilização penal da pessoa jurídica, conquanto não se possa apontar em tal concepção a superação das teorias antecedentes, até porque, como

momento actual. Trad. Juan Córdoba Roda. Barcelona: Bosch, 1959, p. 61-63), HANS-HeINRICH JESCHECK (JESCHECK, Hans-Heinrich. Tratado de derecho penal: parte genereal. 4 ed. Trad. José Luiz Mazanares Samaniego: Comares, 1993, p. 380), SCHMIDHÄUSER (ver: ROXIN, Claus. Culpabilidad y prevención en derecho penal. Trad. Francisco Muñoz Conde. Madrid: Reus, 1981, p. 66) e REINHART MAURACH (MAURACH, Reinhart. Tratado de derecho penal. v.2. Trad. Juan Córdoba Roda. Barcelona: Ediciones Ariel, 1962, p. 36).

${ }^{175}$ COBO DEL ROSAL, Manuel; VIVES ANTÓN, Tomás S. Derecho penal: parte general. Valencia: Tirant lo Blanch, 1990 , p. 515-516.

${ }^{176}$ FERRAJOLI, Luigi, Derecho y razón: teoría del garantismo penal. 8 ed. Madrid: Trotta, 2006, p. 419.

${ }^{177}$ CEREZO MIR, José. Culpabilidad y pena. Anuario de Derecho Penal y Ciencias Penales. tomo XXXIV, fasc. II. Madrid: Ministerio da Justicia-Boletín Oficial del Estado, 1980, p. 362-364.

${ }^{178}$ STRATENWERTH, Günther. Derecho penal: parte general. Trad. Gladys Romero. Madrid: Edersa, 1982, p. 71

${ }^{179}$ Sobre isso, afirma FABIO GUEDES DE PAULA MACHADO que "se esforça a nova concepção em demonstrar empiricamente parte de seu substrato, conquanto ela mesma reconheça a indemonstrabilidade de sua outra parte, persistindo aqui todas as críticas anteriormente deduzidas”. MACHADO, Fabio Guedes de Paula. Culpabilidade..., p. 104. 
se disse, há um movimento pendular que muitas vezes retoma ideias anteriores para redesenhá-las nos dias de hoje. De qualquer modo, não se pode descurar da importância do papel que as teorias funcionalistas têm desempenhado no discurso crítico voltado para a Ciência do Direito Penal, sobretudo pela busca de uma reaproximação entre dogmática e política criminal.

É bem verdade que as construções que se inserem no bojo dessa nomenclatura "funcionalismo" em muito se distinguem. Assim, ainda que haja caracteres em comum como a busca pela reaproximação do direito penal à realidade; o reconhecimento da influência dos fins da pena na determinação dos elementos do delito; bem como o abandono dos valores apriorísticos neokantistas, da compreensão embasada em dados naturais do positivismo causalista, ou nos conceitos ontológicos e pré-jurídicos do finalismo - as manifestações teóricas funcionalistas são diversas, fundando-se quer em argumentos político-criminais, como se verifica em ROXIN e em HASSEMER, aquele construindo um sistema teleológico, este buscando a humanização do Direito Penal ${ }^{180}$, quer em análises estritamente sistêmicas, como visto em JAKOBS ${ }^{181}$. Bem por isso, no específico tema da culpabilidade, as soluções surgidas buscando-se superar a crise de fundamentação da teoria normativa, não se apresentaram de forma unívoca, havendo concepções amparadas pela reformulação do conceito e até mesmo por sua própria negação, em certa medida.

Desse modo, e até para melhor amparar a análise que se pretende fazer das formulações de culpabilidade (ou de critério assemelhado) voltadas para a responsabilidade penal da pessoa jurídica, parece-nos importante nos deter com mais afinco nas construções teóricas de dois autores: RoXIN e JAKOBS.

\subsection{A culpabilidade em Roxin}

\footnotetext{
${ }^{180}$ CHAVES CAMARGO, Antonio Luis. Imputação objetiva e direito penal brasileiro. São Paulo: Cultural Paulista, 2002, p. 34-38.

${ }^{181}$ Sobre isso, ver: GRECO, Luis. Introdução à dogmática funcionalista do delito: em comemoração aos trinta anos de "Política criminal e sistema jurídico-penal" de Roxin. Revista Brasileira de Ciências Criminais. v. 8, n. 32, p. 120-163, 2000. Afirma o autor que "Jakobs funcionaliza não só os conceitos, dentro do sistema jurídico- penal, como também este, dentro de uma teoria funcionalista-sistêmica da sociedade, baseada nos estudos sociológicos de Niklas Luhmann.”. Id. Ibid., p. 128.
} 
A busca pela aproximação sistêmica entre a política criminal e o Direito Penal constitui o cerne do sistema teleológico e funcional por RoxIN construído desde os anos $70^{182}$. Nessa concepção, os dois pilares de seu sistema reformulado estarão assentados sobre a imputação objetiva do resultado e a culpabilidade.

Quanto a esta última, passa a se ligar à indagações a respeito da necessidade da sanção penal, revelando a orientação fundada na teoria dos fins da pena. A bem da verdade, pode-se distinguir dois momentos na teoria de RoXIN sobre culpabilidade. Um primeiro, em que há a funcionalização da culpabilidade em relação às exigências de prevenção, e um segundo, em que se enfatiza o papel garantístico da culpabilidade, atuando no momento de fundação da pena, desfuncionalizando, em parte, a necessidade preventiva $^{183}$.

Num primeiro momento do pensamento roxiniano, não parece tão clara a distinção entre culpabilidade e responsabilidade, posto que o paradigma normativo de ambas é orientado em termos preventivos. Nesse sentido, é perceptível que a culpabilidade, nessa fase, também vem determinada pelos fins da pena, isto até como resultado da crítica empreendida à teoria retributiva. É bem verdade que, já nesse momento, Roxin percebe que a culpabilidade constitui apenas um fator para a responsabilidade penal, na medida em que possível que se reconheça sua configuração sem que se possa, contudo, dirigir uma sanção penal ao agente quando esta se mostre desnecessária. Essa percepção leva a afirmar que a culpabilidade seria baseada na impossibilidade de evitar o fato ilícito, enquanto a responsabilidade se fundaria no escopo da pena, distinção que, contudo, não permite superar o problema do conteúdo da culpabilidade, qual seja, o que seria o "não poder evitar um fato antijurídico". Tendo-se em mente, então, que o deslocamento da teoria retributiva para a preventiva é essencial na diferenciação desse conteúdo, percebe-se que a culpabilidade deve estar em conformidade com a valoração político-criminal adotada, dependendo, portanto, do escopo da pena.

\footnotetext{
${ }^{182}$ CHAVES CAMARGO, Antonio Luis. Imputação objetiva..., p. 36.

${ }^{183}$ Essa distinção é delineada por TULLIO PADOVANI, que afirma: "La riflessione roxiniana si sviluppa com'è notto - in un arco di tempo piuttosto lungo, e si caratteriza per una evoluzione che, in modo graduale, sembra muovere da una prospettiva originaria in cui la colpevolezza è concepita essenzialmente in termini funzionali rispetto alle esigenze della prevenzione, ad una prospettiva in cui predomina invece una nota di disfunzionalittà do carattere garantistico.”. PADOVANI, Tullio. Teoria della colpevolezza e scopi della pena. Rivista Italiana di Diritto e procedura penale. anno XXX. Milano: Dott. A. Giuffrè Editore, p. 801, 1987.
} 
Essas constatações culminam, no limite, em uma confusão entre culpabilidade e responsabilidade, levando aquela a se resolver nesta ${ }^{184}$, remanescendo seu papel autônomo, nesse momento, apoiado apenas no seu entendimento como "condição necessária, mas não suficiente, para a punibilidade" ${ }^{\text {"185 }}$.

Num segundo momento, entretanto, Roxin move o eixo da relação entre culpabilidade e prevenção para uma dimensão mais disfuncional ${ }^{186}$. Percebe-se que a prevenção não tem, por si só, a capacidade de limitar o poder punitivo estatal de modo adequado ao Estado de Direito, isso tanto na definição da pena, como também no âmbito de definição da punibilidade. Busca, portanto, realçar as vantagens garantísticas do princípio da culpabilidade, tendo em conta as objeções teóricas já endereçadas a ele, e harmonizando-o com a finalidade preventiva do direito.

Não há mais, nessa fase da evolução do pensamento do aludido autor, a vinculação do conteúdo da culpabilidade a uma perspectiva de caráter preventivo, na medida em que, reconhecendo-a como meio de limitar a sanção orientada pelo escopo preventivo, não fundamenta a necessidade de uma pena, mas sim circunscreve o âmbito de sua admissibilidade. Perceba que os fins da pena exercem, nesse segundo momento, o papel de limite da culpabilidade, e não de componente de sua estrutura de conteúdo.

Nesse sentido, pode-se afirmar que a culpabilidade, na teoria de RoXIN, pela leitura mais atual, passa a ser elemento de uma nova categoria dogmática: a responsabilidade. Assim, para a imposição da pena não bastará a verificação de ser o agente delitivo culpável, mas também deve-se indagar sobre a necessidade sancionatória, revelando-se, com isso, a concreta influência da política criminal.

Para a aferição da culpabilidade no sistema roxiniano, verifica-se se ao autor era possível o conhecimento da ilicitude, bem como se atuara em situação de normalidade. Volta-se, portanto, as preocupações para a acessibilidade intelectual do autor ao comando normativo, observando-se sua capacidade de controle e possibilidade de cumprimento do disposto na norma jurídica. Consigne-se que há o descarte da ideia de culpabilidade como um "poder agir de outro modo" no momento do fato, porquanto empiricamente indemonstrável tal critério. Sua construção volta-se, assim, para uma liberdade de agir compreendida não como fato real, mas como assunto normativo, tendo em conta, portanto,

\footnotetext{
${ }^{184}$ Id. Ibid., p. 808.

${ }^{185}$ ROXIN, Claus. Culpabilidad..., p. 5

${ }^{186}$ Id. Ibid., p. 811.
} 
a dimensão jurídica das relações sociais, em que há a assunção dessa liberdade, e não com fundamento em critérios filosóficos ou psicológicos ${ }^{187}$.

Bem por isso, é perceptível, também, que há em sua formulação influências de política criminal, sobretudo porque este discurso de aferição de tais capacidades individuais muito se pauta no preenchimento de expectativas sociais, observando-se que não pretende a sociedade que pessoas destituídas de aptidão para se motivar sejam sancionadas pelo descumprimento da lei.

Diante dessa construção, parece evidente que a culpabilidade deixa de constituir fundamento para a necessidade da pena, até porque não é dela que defluirá a necessária aplicação desta. Passa a desempenhar o papel, em verdade, de critério limitador da sanção, da função preventiva do Direito Penal. Assim, a aferição da necessidade da pena, como elemento constitutivo posterior à culpabilidade na determinação da responsabilidade, será reciprocamente limitadora e limitada pela culpabilidade.

Tem destaque, ainda, na construção de RoxIN, a definição do conceito material de culpabilidade, que, para ele, constitui o cerne conceitual deste elemento do crime (subelemento, agora, se entendido como componente de um novo elemento - a responsabilidade), posto que apenas com a determinação de seu conteúdo, ou seja, com a delimitação daquilo que permite valorar uma conduta como culpável ou não, é que se pode determinar uma linha de interpretação de todos os componentes da culpabilidade ${ }^{188}$. Nesse sentido, vai definir a culpabilidade materialmente como a "atuação injusta do sujeito em que pese poder cumprir a norma"189. Para o autor, tal concepção permite fugir dos “conceitos abrangentes, mas vazios de conteúdo" que não identificam o que se está reprovando ou imputando subjetivamente ${ }^{190}$, ressaltando que a capacidade para ser destinatário de normas é passível de verificação empírica por meio de métodos psicológicos ou psiquiátricos, diversamente de conceitos como o "poder agir de outro modo" ou mesmo o "livre-arbítrio"

\footnotetext{
${ }^{187}$ Id. Ibid., p. 811-812.

${ }^{188}$ ROXIN, Claus. Culpabilidad..., p. 59. Ver, também: MACHADO, Fabio Guedes de Paula. Culpabilidade..., p. 135

${ }^{189}$ ROXIN, Claus. Derecho Penal: Parte General. Trad. Diego-Manuel Luzón Pena, Miguel Díaz y García Conlledo, Javier de Viente Remesal. Madrid: Civitas, 2001, p. 807

${ }^{190}$ ROXIN, Claus. A culpabilidade e sua exclusão no direito penal. Revista Brasileira de Ciências Criminais. São Paulo, v. 12, f. 46, p. 51, jan.-fev. 2004.

${ }^{191}$ Id. Ibid., p. 58.
} 
O que parece essencial, em resumo, na concepção mais atual de Roxin sobre a culpabilidade é que, entendendo-a como pressuposto, juntamente com a necessidade da pena, da responsabilidade, reconhece-se a influência da teoria dos fins da pena para a teoria geral do delito, posto que a sanção penal só pode ser justificada pela presença dos dois critérios ${ }^{192}$.

Críticas foram direcionadas à construção de culpabilidade de RoxIN, fundadas, sobretudo, na estrita conexão estabelecida entre Direito Penal e política criminal, que traduziria sua submissão ao utilitarismo, afastando-se, portanto, do ideal de Justiça ${ }^{193}$.

\subsection{A culpabilidade em JAKOBS}

Para entender a culpabilidade na construção de JAKOBS deve-se ter em mente a fundamentação teórica de suas concepções. Adepto de um funcionalismo sistêmico, radical, entende como papel do Direito Penal não a tutela de bens jurídicos, mas a estabilização social por meio da afirmação da norma como modelo de determinação das expectativas emanadas das relações sociais. O crime, portanto, seria a quebra dessa expectativa, possuindo a pena um papel comunicativo de reafirmação da norma, da expectativa por ela emanada. Revela-se em sua teoria a influência do pensamento de LUHMANN $^{194}$.

Em sua concepção, o Direito Penal, e, por conseguinte, a pena, tem uma função sistêmica, de reafirmação da norma. A norma, portanto, constitui o elemento fundamental de proteção do sistema, afastando-se das finalidades voltadas à proteção humana como valor máximo, e, consequentemente, das indagações atinentes à legitimação material do Direito Penal, que acaba sendo meramente formal, sistemática.

Interessante que, para essa teoria, a culpabilidade terá papel central. Isto porque, no limite, o que importa ao Direito Penal é a possibilidade ou não de sancionar. A culpabilidade, assim, se traduz num déficit de fidelidade à norma indicado por elementos

\footnotetext{
${ }^{192}$ Id. Ibid., p. 65.

${ }^{193}$ MACHADO, Fabio Guedes de Paula. Culpabilidade..., p. 144

${ }^{194}$ Observando-se que, para SILVA SÁNCHEZ, JAKOBS vêm cada vez mais se aproximado da teoria hegeliana. SILVA SÁNCHEZ, Jesús-Maria. Consideraciones sobre la teoría del delito. Buenos Aires: Ad-hoc, 1998, p. 28. Contudo, discorda desse posicionamento FABIO GUEDES DE PAULA MACHADO, para quem JAKOBS ainda permance fiel à base sociológica. MACHADO, Fabio Guedes de Paula. Culpabilidade..., p. 145.
} 
psíquicos como o dolo e a consciência da ilicitude ${ }^{195}$, que torna exigível a pena para a reafirmação da norma perante a sociedade. Pune-se para "manter a confiança geral na norma, para exercitar o reconhecimento geral da norma" ${ }^{„ 196}$. Vê-se, portanto, que a culpabilidade é condicionada pela exigência de prevenção geral, e não pela aferição das condições de responsabilidade pessoal do autor.

Bem por isso, afirma JAKOBS que o conceito de culpabilidade está orientado para o presente, e não ao futuro ${ }^{197}$. Define o autor a culpabilidade como "responsabilidade por um déficit de motivação jurídica dominante em um comportamento antijurídico”, chegando a denominá-la como "infidelidade ao Direito" "198. À culpabilidade caberia o papel de caracterizar a motivação do agente contrária ao Direito ${ }^{199}$ que torna exigível a incidência da pena para reafirmar a confiança social na norma e, por conseguinte, a manutenção do ordenamento jurídico. Alija-se, portanto, a culpabilidade de seu papel de limitação da pena, posto que seu reconhecimento será pautado pelas necessidades preventivas gerais. O ser culpável, assim, deriva de um defeito organizacional do agente, que se conduz de forma infiel ao Direito, ainda que inexistam obstáculos jurídicos para assim se comportar, abrindo espaço, portanto, à aplicação da pena para estabilizar o conteúdo normativo no seio social, necessidade de estabilização essa que acaba se convertendo no próprio conteúdo material da culpabilidade.

Importa, ademais, à constatação da culpabilidade, a relevância comunicativa da ação do autor, aferida conforme a valoração advinda do sistema social, e não consoante as características naturais afetas a esse agir, como a motivação do agente ou outras manifestações de cunho subjetivo.

Sustenta JAKOBS, portanto, que o conceito de culpabilidade configura-se funcionalmente, na medida em que constitui um conceito que "produz um fruto de regulação", consoante determinados princípios (ou seja, conforme os requisitos do fim da pena), para uma "sociedade de estrutura determinada". Em outras palavras, seu conceito

\footnotetext{
${ }^{195}$ JAKOBS, Günter. Sobre la normativización de la dogmática jurídico-penal. Trad. Manuel Cancio Meliá e Bernardo Feijóo Sánchez. Madrid: Civitas, 2003, p. 22.

${ }^{196}$ JAKOBS, Günther. Derecho Penal..., p. 581.

${ }^{197}$ Id. Ibid., p. 581.

${ }^{198}$ Id. Ibid., p. 566.

${ }^{199}$ Id. Ibid;, p. 579.
} 
delineia esquematicamente um sentido geral para a culpabilidade, que apenas será concretamente definido quando referido a um certo sistema social ${ }^{200}$.

Interessante que, por essa concepção, entende-se o livre arbítrio como irrelevante, posto que não se indaga mais sobre o "desvalor do indivíduo", mas, guiando-se pelo fim de assegurar a ordem social (objetivo de sua teoria funcional extremada), a culpabilidade questiona se há uma alternativa de organização genericamente preferível, o que possibilitará a imputação ao autor. O poder atuar de forma diversa constitui, então, uma construção normativa ${ }^{201}$. Consigna, aliás, JAKOBS, que essa ideia não afasta a relação entre responsabilidade e liberdade, posto que o indivíduo apenas pode ser culpável num âmbito de liberdade, onde possa se autodeterminar. Contudo, essa autodeterminação não se define pelo livre arbítrio, mas pela inexistência de "obstáculos juridicamente relevantes para seus atos de organização" ${ }^{, 202}$.

Uma culpabilidade não ajustada a fins impede, na visão de JAKOBS, a função de limitação do mínimo da pena necessário à proteção social. A culpabilidade determinada de maneira geral, sem apoio no fim da pena, impossibilitaria a mensuração do mínimo necessário para que se alcance a proteção da sociedade ${ }^{203}$. Nesse raciocínio, aliás, critica a noção roxiniana de culpabilidade, ressaltando que a utilização desta como mera limitação da pena, a qual se fundamenta preventivamente, sem relacionar a culpabilidade a fins, impede que esta defina qualquer medida da sanção ${ }^{204}$.

A estruturação da culpabilidade de JAKOBS, de outro lado, se dá de forma tipológica. Constrói o que denomina "tipo total de culpabilidade", formado pelo tipo de culpabilidade (conjunção dos elementos necessários para vislumbrar-se a infidelidade ao direito - tipo positivo de culpabilidade) e pelo tipo de exculpação (elementos de inexigibilidade - tipo negativo de culpabilidade), tipo total esse que, juntamente como o "tipo de injusto", conformam o delito.

\footnotetext{
${ }^{200}$ Id. Ibid., p. 584.

${ }^{201}$ Id. Ibid., p. 587.

${ }^{202}$ Afirma JAKOBS: “[...] este concepto, que desde luego carece de dimensión social, es necesario sólo si con el juicio de culpabilidad no ha de conseguirse únicamente un efecto social, sino también una desvaloración del indivíduo ("reprochabilidad"). Pero si nos limitamos al aseguramiento del orden social, en la culpabilidad ya no se trata de si el autor tiene realmente, y no sólo desde una determinación normativa, una alternativa de organización que sea preferible en general.”. Id. Ibid., p. 585.

${ }^{203}$ Podera o autor: "Si se parte, com la doctrina usual, de un concepto de culpabilidad no ajustado a fines, nada garantiza que una culpabilidad determinada así sólo por lo general esté en concordancia con lo necesario para la protección de la sociedad. Un concepto de culpabilidad así determinado no puede, pues, indicar nada en relación com el límite inferior de la pena”. Id. Ibid., p. 590.

${ }^{204}$ Id. Ibid., p. 590.
} 
Nessa construção, o tipo (positivo) de culpabilidade é formado pela totalidade do injusto $^{205}$ - face objetiva necessária para a verificação do defeito motivacional e que é considerada, nesse âmbito, sob o foco da relação subjetiva (do conhecimento) do autor em relação ao injusto, constituindo-se pelo comportamento típico evitável e não justificado -; pela imputabilidade ${ }^{206}$ - entendida como a posse de uma competência de pôr em questão a validade da norma, a qual se funda na igualdade, ou seja, na presença, no autor, de elementos essenciais que formam ou não impedem o processo motivacional e o sucesso dele -; pela motivação juridicamente incorreta; e, em certos, casos, pelos especiais elementos da culpabilidade, que atendem à competência ou competência intensificada por uma infração de dever ${ }^{207}$.

Já o tipo negativo de culpabilidade é verificado quando o agente atua sob uma “disposição de ânimo exculpante" ou em uma condição contextual também exculpante, as quais excluem ou diminuem a culpabilidade (inexigibilidade) ${ }^{208}$.

Muitas críticas são dirigidas à teoria de JAKOBS, fundadas, essencialmente, na prevalência da norma (de sua reafirmação perante a sociedade) como objetivo essencial de seu modelo, e, em consequência, o descaso com a pessoa humana e sua dignidade, que deveriam orientar o sistema penal. O indivíduo deixa de ser o cerne desse sistema, passando a ser considerado mero "centro de imputação de responsabilidades" 209 , abrindose espaço, portanto, para justificar qualquer tipo de discurso jurídico, dado o fim funcional de sua teoria sistêmica. Essa formulação de culpabilidade (e de Direito Penal), essencialmente formal e destituída de conteúdo, pode servir, portanto, a qualquer senhor, o que seria inaceitável.

Observa-se, ademais, que por se estruturar numa finalidade de reafirmação das normas e, portanto, do sistema, a concepção jakobesiana afasta-se tanto da valoração do autor como do fato, e não permite divisar um conteúdo possível de fornecer parâmetro para se delimitar a dimensão da sanção necessária à dita estabilização da confiança no ordenamento jurídico, destituindo a culpabilidade de seu caráter de limitação do jus puniendi estatal.

\footnotetext{
${ }^{205}$ Id. Ibid., p. 598.

${ }^{206}$ Id. Ibid., p. 598-600.

${ }^{207}$ Id. Ibid., 600.

${ }^{208}$ Id. Ibid., 600-601.

${ }^{209}$ GARCÍA-PABLOS DE MOLINA, Antonio. Derecho penal: introducción. Madrid: Universidad Complutense - Servicio de Publicaciones, 1995, p. 381.
} 
Deve-se ter em mente, ainda, que tal teoria, ao se fechar em considerações sistêmicas, não dota o Direito Penal da possibilidade de se arejar pelas influências de outras ciências, como a política criminal, posto que se orienta tautologicamente para a sua autoafirmação social. E, no limite, chega JAKOBS a negar qualquer papel à culpabilidade no esquema do Direito Penal do Inimigo, onde o comportamento do indivíduo destitui-lhe da condição de cidadão, permitindo a aplicação do Direito Penal sem qualquer das garantias que lhe seriam inerentes ${ }^{210}$.

\subsection{A busca por um conceito material de culpabilidade}

Presentes esses modelos teóricos de culpabilidade, que se seguem não de maneira evolutiva linear, de superação, mas numa remodelação conceitual que por vezes revisita ideias anteriores, percebe-se, de maneira geral, uma condução do psicologismo subjetivista, para um abstrativismo, quer normativo, quer funcional, muitas vezes com a utilização de categorias sociais para solucionar problemas relacionados à indemonstrabilidade de seus pressupostos. Diante de construções diferenciadas de composição da culpabilidade, o que nos preocupa de maneira central é a definição material desse elemento do crime, com o delineamento de seu conteúdo e, portanto, do critério reitor de avaliação da conduta como passível de reprovação penal. Essa preocupação central advém da circunstância de ser no critério material que reside o cerne da crise do conceito de culpabilidade e também porque é nele que se revela em conteúdo (e não como mero elemento negativo de constatação, como o é a culpabilidade formal) o caráter "humano" da culpa, que tem sido argumento para se repudiar uma culpabilidade dos entes coletivos.

Enquanto a culpabilidade formal se traduz em indicadores negativos que possibilitam a imputação do fato ao agente (e cuja adaptação também consistirá num

\footnotetext{
${ }^{210}$ Sobre isso, afirma MANUEL ABANDO VASQUEZ: "Con motivo de la Jornada Berlinesa de 1999, Jakobs retomó y radicalizó esta idea en el sentido de que, en la situación actual, en la que el dominio del sistema económico y la globalización exigen a la ciencia penal una efectividad en la protección de bienes, una sociedad consciente de los riesgos no tendría outra alternativa que construir un Derecho Penal del enemigo, unas reglas especiales - distintas de las del Derecho penal del ciudadano - dirigidas a las no personas, o sea, a aquellas que se hayan apartado permanentemente del Derecho". ABANTO VASQUEZ, Manuel A.. El llamado derecho penal del enemigo. Especial referencia al derecho penal económico. In: CANCIO MELIÁ, Manuel; GÓMEZ-JARA DÍEZ, Carlos (coord.). Derecho Penal del Enemigo. El discurso penal de la exclusión. Buenos Aires: Edisofer, 2006, p.3.
} 
desafio para a responsabilidade penal da pessoa jurídica), o conceito material é o próprio fundamento da culpabilidade ${ }^{211}$, o que justifica a sua existência. Daí sua importância para se reconhecer um espaço possível de construção de uma culpabilidade da pessoa jurídica, para avaliar se tal reconhecimento implicaria negar a existência de tal culpabilidade, ou se é possível a convivência (como critério único ou de forma paralela) desses conceitos.

De outra banda, somente o conteúdo da culpabilidade é que revelará nela o caráter de limitação do exercício do poder punitivo estatal ${ }^{212}$, caráter esse essencial por distinguir uma responsabilidade penal fundada na culpabilidade e não em outros critérios $^{213}$.

A grande contribuição, por ora, de deter a análise sobre o conteúdo material da culpabilidade, é reconhecer a crise desse conceito e, portanto, o espaço para novas soluções, sem que essas impliquem num distúrbio de uma dogmática perfeita que, como se verá, não existe. Apontaremos, assim, as principais teorias relativas à definição do conteúdo material da culpabilidade, incluindo a própria negação da culpabilidade.

\subsubsection{A culpabilidade como "poder atuar de outro modo" (teoria social da culpabilidade)}

Por essa concepção, também denominada de "poder médio" (andershandelnkönnen) $^{214}$, a culpabilidade se traduziria na reprovação do comportamento de um sujeito que não omitiu a ação antijurídica, conquanto lhe fosse possível. Essa possibilidade de atuação diversa é mensurada conforme o comportamento de um modelo de homem, um "homem na medida" (massgerechten), nas palavras de JESCHEK ${ }^{215}$. Funda-

\footnotetext{
${ }^{211}$ Sobre isso, ver: CHAVES CAMARGO, Antonio Luis. Culpabilidade..., p. 125-126.

${ }^{212}$ Neste sentido, concordamos com RoxIN, que opta pela culpabilidade, e não pela finalidade preventiva, como meio de limitação do jus puniendi estatal. Afirma o mencionado autor: "[...] la culpabilidade sigue siendo el presupuesto decisivo (aunque no el único) de la responsabilidad jurídicopenal. El hacer depender la punibilidad de la culpabilidad del sujeto tiene como finalidad poner un límite al poder punitivo del Estado (en particular: a las necesidades pública de prevención). Por qué se ha de preferir esta limitación ,por razones derivadas del Estado de Derecho, a una concepción que atienda a la pura finalidad preventiva ha sido expuesto al examinar las teorías de la pena.”. ROXIN, Claus. Derecho penal..., p. 798.

${ }^{213}$ Isto nos parece importante para, mais a frente, analisar as construções de uma culpabilidade do ente coletivo, posto que, para nós, apenas poderá se identificar uma formulação como "culpabilidade" quando se revelar não apenas como um critério apto a efetuar um juízo de imputação subjetivo, mas quando for capaz de limitar o poder punitivo estatal.

${ }^{214}$ MACHADO, Fabio Guedes de Paula, Culpabilidade..., p. 111.

${ }^{215}$ JESCHECK, Hans-Heinrich. Tratado..., p. 386.
} 
se, portanto, na ideia de liberdade de decisão dos sujeitos, que optam ou não pela conduta contrária ao Direito - havendo essa opção pela conclusão de que o homem médio poderia agir de forma diversa, considerando-se as condições do fato e pessoais do autor -, e revelam, com essa última opção, sua culpabilidade.

Críticas sobrevieram a essa teoria. Fundaram-se, essencialmente, na indemonstrabilidade de seu pressuposto, qual seja, o livre arbítrio, além do evidente caráter ficcional de seu parâmetro de valoração da conduta (o "homem médio" e a presumida igualdade com a situação real da prática da ação), que afasta a culpabilidade de uma análise pessoal. Nesse diapasão, aliás, a análise de ROXIN vai mais além, posto que, retirando o foco crítico do livre arbítrio em si, ressaltando que se poderia partir dessa premissa indemonstrável, assevera que, ainda assim, essa concepção falharia, ao encarar a impossibilidade de constatação empírica da possibilidade de se atuar de outro modo. Conclui ou autor que, de qualquer forma, sob qualquer desses ângulos críticos, se a culpabilidade pressupõe um fenômeno não demonstrável empiricamente, então, no limite, deveria sempre conduzir à absolvição fundada na dúvida (in dubio pro reo), impossibilitando, assim, embasar-se o Direito Penal na culpabilidade ${ }^{216}$.

Buscou-se, é bem verdade, dotar de concretude o "poder atuar de outro modo" sustentando-o no comportamento do "homem médio", construído pela experiência consoante a capacidade da maioria das pessoas. Para o dimensionamento da culpabilidade individual empregar-se-ia uma comparação entre a conduta do agente e aquela que possivelmente a pessoa média teria. Mas, como já se disse, essa construção não logrou salvaguardar de críticas a culpabilidade fundada no poder atuar de outro modo, posto que inexiste lógica, numa perspectiva indeterminista, a balizar o comportamento de um indivíduo e, consequentemente, destinar-lhe um juízo de reprovação com base no possível comportamento de terceiros. Haveria nisso, a bem da verdade, a desconsideração do fundamento prévio dessa forma de culpabilidade que reside, justamente, na possibilidade de livre escolha do sujeito ${ }^{217}$, deixando-o receber um juízo de reprovação penal não pela sua culpabilidade própria, mas pela criação de um modelo abstrato de homem e pala valoração da conduta hipotética desse “indivíduo" na mesma situação ${ }^{218}$.

\footnotetext{
${ }^{216}$ ROXIN, Claus. Derecho penal..., p. 799-800.

${ }^{217}$ Sobre isso, afirma Roxin: "Ello no sólo carece de lógica, sino que supone un abandono del punto de partida de que al próprio sujeto le há de ser posible una decisión libre”. Id. Ibid., p. 800.

${ }^{218}$ Nesse ponto, esclarecedora a lição de FABIO GUEDES DE PAULA MACHADO, para quem "[...]a concepção social de culpabilidade é, por fỉm, contraditória, em razão de que o sujeito não é apenado pela sua
} 


\subsubsection{A culpabilidade como atitude interna juridicamente desaprovada}

Por essa concepção volta-se a reprovação ensejada pela culpabilidade para a valoração da atitude interna do agente que se manifesta no comportamento delitivo. $\mathrm{O}$ injusto conteria, assim, o desvalor da ação, e a culpabilidade o desvalor da atitude interna do fato. Essa concepção, fundada por GALLAS, encontrou abrigo nas construções de JESCHECK, com sua "atitude interna juridicamente defeituosa", e em WESSELS, pela "atitude interna juridicamente censurável, atitude defeituosa do agente"219.

Tal teoria, contudo, parece afastar-se da definição de um conteúdo material de culpabilidade, uma vez que não dimensiona nenhum critério para embasar a reprovação jurídica dirigida à atitude interna do agente. Em outras palavras, apenas se define o objeto de valoração, mas não os parâmetros a dirigir o conteúdo do juízo de valor.

Interessante notar que GALLAS ${ }^{220}$ tenta solucionar tal crítica, asseverando que o desvalor da atitude interna do agente é reflexo do desvalor da própria ação e será afastado quando o agente, conquanto comporte-se de forma dolosa, carecia de poder. Tal justificação, contudo, muito se assemelha à construção da culpabilidade fundada no "poder agir de outro modo".

Pensa-se haver, também, uma tentativa de materialização com a construção de JESCHECK, para quem a cognoscibilidade social do modelo de conduta exigível no caso concreto permitirá verificar a culpabilidade. Em outras palavras, para este autor, é o "padrão social de conduta", por assim dizer, que pautará a valoração do fato em face da atitude interna do agente em comparação à exigência do ordenamento jurídico ${ }^{221}$.

Outra concepção que busca dotar de materialidade esta formulação da culpabilidade é a de SCHMIDHÄUSER, para quem a atitude interna, espiritual, reprovável, é aquela que se dirige à lesão do bem jurídico. Nessa concepção, portanto, o bem jurídico se revelará como critério de materialização dessa culpabilidade ao dotar de conteúdo o juízo

culpabilidade, mas sim pelo sujeito hipotético ou imaginário, que na situação objeto teria agido de modo diverso ao realizado pelo homem real". MACHADO, Fabio Guedes de Paula. Culpabilidade..., p. 113.

${ }^{219}$ ROXIN, Claus. Derecho penal..., p. 800.

${ }^{220}$ Id. Ibid., p. 801.

${ }^{221}$ JESCHECK, Hans-Heinrich. Evolução do conceito jurídico penal de culpabilidade na Alemanha e na Áustria. Trad. Patrícia Esquinas Valverde. Revista Electrónica de Ciencia Penal y Criminologia, n. 5, p. 10, 2003. Disponível em: <http://criminet.ugr.es/recpc/05/recpc05-01.pdf〉. Acesso em: 24 maio 2012. 
de valor que é dirigido à atitude interna (o comportamento espiritual e o comportamento da vontade externado na ação lesionam bem jurídico). Perceba-se que, por essa teoria, nem se cogita sobre o livre arbítrio, porquanto a culpabilidade vai se fundar no desacerto valorativo entre a atitude interna do agente e o bem jurídico tutelado pela norma ${ }^{222}$. E acrescenta SCHMIDHÄUSER que sua teoria pode, inclusive, albergar a imprudência inconsciente, posto que, mesmo nesses casos, é a possibilidade da pessoa dispor, no momento da ação, do valor lesionado com sua conduta, ainda que de forma inconsciente, que permite constatar sua culpabilidade ${ }^{223}$. Essa disponibilidade se aproxima, então, da ideia de exequibilidade normativa, consoante RoxIN ${ }^{224}$. Objeta-se, contudo, tal teoria, por não esclarecer de que forma se pode, inconscientemente, ter um comportamento interno que se dirige contra o bem jurídico tutelado, na medida em que um comportamento interno exige uma tomada de postura interna, bem como a ciência do objeto em relação ao qual se adota certa postura $^{225}$.

Dessa forma, pode-se afirmar, em síntese, que a grande crítica a tal teoria (sob qualquer de suas vertentes) é quanto à impossibilidade de se verificar a culpabilidade nos casos de imprudência inconsciente, posto que nestes casos inexistiria uma atitude interna juridicamente reprovável.

\subsubsection{A culpabilidade como decisão consciente da vontade pelo ilícito}

Esta definição material de culpabilidade, que encontra guarida nas ideias de ARTHUR KAUFFMAN ${ }^{226}$, funda-se na decisão consciente da vontade que opta de forma contrária à proibição, cujo conteúdo se alcança por meio da representação da possibilidade ou certeza da produção de um resultado delitivo (não permitido). Nesse aspecto, o poder agir de outro modo não constituirá o conteúdo material da culpabilidade, mas sim seu pressuposto.

A exigência de uma decisão consciente contrária ao direito comporia materialmente o conteúdo da culpabilidade, o que traz, desde logo, um dilema enfrentado

\footnotetext{
${ }^{222}$ ROXIN, Claus. Derecho penal..., p. 801.

${ }^{223}$ Id. Ibid., p. 801.

${ }^{224}$ Id. Ibid., p. 802.

${ }^{225}$ Id. Ibid., p. 802.

${ }^{226}$ Sobre isso, ver: FIGUEIREDO DIAS, Jorge de. Liberdade, culpa e direito penal. Coimbra: Coimbra Editora, 1995, p. 59 e ss.
} 
também pelas teorias fundadas na atitude interna do agente, qual seja, a impossibilidade de se albergar a "negligência inconsciente". Como afirma FIGUEIREDO DiAs, ao se fundar a culpabilidade na decisão consciente, acaba-se convertendo o dolo no substrato material único dessa culpabilidade ${ }^{227}$.

Os defensores dessa teoria afirmam que, nos casos de negligência inconsciente, afirmar-se o reconhecimento de uma culpabilidade material, fundando-a, exclusivamente, no poder agir de outro modo, sem a existência de uma "real decisão da vontade", resultaria numa concepção de culpabilidade que, em verdade, teria como base não a pessoa do agente, mais o juízo valorativo emanado pelo julgador ${ }^{228}$. Rebate-se, contudo, tal argumento, afirmando que é possível reconhecer nessa modalidade inconsciente de culpa a culpabilidade material fundada no poder agir de outro modo, sem que com isso se impeça a busca da "decisão da vontade pelo ilícito" em outros critérios diversos da culpabilidade, como, por exemplo, na própria ação ${ }^{229}$.

\subsubsection{A culpabilidade como capacidade de motivação pela norma}

As teorias da motivação da norma (salientando-se que há várias acepções) 230 $^{23}$ possuem como traço comum fundarem-se na imperatividade do conteúdo normativo, entendendo-se a culpabilidade como fenômeno social que conjuga a motivação emanada pela norma e a capacidade do sujeito de determinar-se conforme esta exigência. Há uma releitura do "poder agir de outro modo", que agora não mais tem por base o genérico livrearbítrio, mas as condições do indivíduo de se motivar conforme a norma e escolher por se conduzir consoante esta motivação. Para concluir por essa "capacidade de motivação", observam-se as habilidades mentais do agente ${ }^{231}$.

\footnotetext{
${ }^{227}$ Id. Ibid., p. 60.

${ }^{228}$ KAUFFMAN, Arthur. Schuldprinzip, p. 174-187. apud FIGUEIREDO DIAS, Jorge de. op. cit., p. 63.

${ }^{229}$ Sobre isso, afirma FIGUEIREDO DIAS: "O acentuar que a negligência inconsciente é verdadeira culpa material, na medida em que o agente podia ter-se comportado de modo diferente, apenas significa que a culpa não supõe necessariamente, como seu substrato material, uma decisão da vontade pelo ilícito, mas não impede que um tal substrato se busque em qualquer outro lado (v.g. logo na própria manifestação de vontade corporizada na ação que, ela sim, é ilícita por um lado e culposa por outro). Com isto, todavia, em nada se decide se a culpa é mero juízo de valor, ou se dela fazem parte o dolo e a negligência, ou pelo menos certos elementos a estes pertencentes. De uma ou de outra forma, a negligência inconsciente será verdadeira culpa material e como tal deverá ser valorada”. Id. Ibid., p. 64.

${ }^{230}$ Cf. MACHADO, Fabio Guedes de Paula. Culpabilidade..., p. 115.

${ }^{231}$ Id. Ibid., p. 114.
} 
As críticas efetuadas a essa teoria, em certa medida, não se diferenciam daquelas empreendidas em face da culpabilidade fundada no "poder agir de outro modo", envoltas, essencialmente, na problemática da indemonstrabilidade de seu fundamento, agora não mais relacionado diretamente ao livre-arbítrio, mas a essa "motivabilidade". Diante desse questionamento, acaba-se recorrendo a soluções também falhas, como a presunção normativa de que os indivíduos não motiváveis não podem ser responsabilizados, retomando-se o critério comparativo do "homem médio".

Aponta-se, ainda, uma deficiência dogmática em relação a tal teoria da culpabilidade atrelada à questão da imputabilidade. Nesse sentido, segundo a interpretação de Jorge DE FIGUEIREDo DiAs, adotando-se o critério da capacidade de motivação pela norma como conteúdo material da culpabilidade, acaba-se por diminuir a culpabilidade e a pena em situações de imputabilidade atenuada, mas de significação criminal relevante, por revelar maior probabilidade de reincidência ${ }^{232}$. Exemplifica com os casos em que o criminoso, em virtude de uma "tendência para o crime", e não de uma anomalia psíquica, não consegue, ainda que podendo perceber a ilicitude do fato, determinar-se consoante essa avaliação, ou seja, a despeito de ser imputável segundo os critérios biopsicológicos, não é capaz de motivar-se pelas exigências normativas ${ }^{233}$. Presente esse espectro, entende o autor que tal teoria acaba por relegar a imputabilidade a um papel "secundário", por assim dizer, na verificação da culpabilidade, posto que, ainda que esteja presente, o que será decisivo é a constatação da capacidade de motivação conforme a norma (independentemente da anterior verificação da imputabilidade consoante os critérios biopsicológicos).

Desse modo, entende FigUEIREDo DiAs que, adotando-se a teoria da motivação consonante a norma, acaba-se por tornar a teoria da imputabilidade irrelevante,

\footnotetext{
${ }^{232}$ FIGUEIREDO DIAS, Jorge de Figueiredo. op. cit., p.72.

${ }^{233}$ Aponta o autor: "[...] segundo a concepção tradicional e prevalente da teoria da imputabilidade, será capaz de culpa ou imputável v. g. o criminoso que, não em virtude de uma anomalia psíquica mas de uma tendência inveterada para o crime, consegue ainda avaliar a ilicitude do facto que pratica mas não já determinar-se de acordo com aquela avaliação; como o será, v. g. o criminoso profissional embotado por sentimentos que, não por anomalia mental mas pela pobreza de espírito resultante de uma vida indolente e vazia, se tornou incapaz de uma motivação de acordo com a norma; como o será finalmente v. g. o jovem adulto que, não por anomalia mental mas por deficiente desenvolvimento espiritual e moral, condicionado por factores sociais inevitáveis - aliás cada dia mais frequentes - máxime os derivados de um meio pernicioso a que não pode escapar, não possui capacidade para se motivar de acordo com a norma. Que sentido terá, porém, considerar imputáveis e capazes de culpa todos estes delinquentes (pessoal e concretamente incapazes de uma motivação de acordo com a norma), se a teoria da imputabilidade for só, como quer a tese em exame, parte não autónoma da verificação da existência global de uma unitária capacidade de motivação de acordo com a norma?". Id. Ibid., p.68-69.
} 
desnecessária, afastando qualquer ligação do fundamento biopsicológico com o elemento normativo $^{234}$.

\subsubsection{A culpabilidade como dever responder pelo caráter próprio}

Por esta construção cada indivíduo é responsável por seu "ser assim”, por suas características que o induziram à certa conduta. Evidentemente determinista, funda a culpabilidade no caráter do agente. A reprovação se dirige não só ao fato, mas também ao ser, pois se entende que a conduta é apenas emanação de uma personalidade.

A referência ao caráter, personalidade do agente, para fundamentar a culpabilidade, não se desenvolveu, a bem da verdade, de forma unitária e linear. A culpabilidade pelo caráter encontrou albergo, entre os doutrinadores alemães, na concepção da "culpabilidade pela condução de vida" de MEZGER, na "culpabilidade na decisão de vida", de BocKelmann, e na "culpabilidade do agente", de LANGE. Ainda que referindo, todas, à construção do caráter do agente e sua valoração, possuem peculiaridades que as distinguem.

$\mathrm{Na}$ “culpabilidade pela condução de vida” de MEZGER, a reprovação penal será dirigida ao agente por ter adquirido componentes culposos, formatando assim o seu caráter, o seu modo de ser. Para tanto, distingue o autor entre componentes culposos e não culposos do caráter, o que foi alvo de severas críticas à sua teoria, tendo-se em conta a impossibilidade do julgador de alcançar concretamente tal distinção ${ }^{235}$. Nesse sentido, JAKOBS assevera que, a tentativa de se restringir a culpabilidade pela condução de vida aos casos em que a conformação da vida é evitável, voltando-se, portanto, a reprovação à situações de opção concreta, significaria, em verdade, a "introdução de uma culpabilidade

\footnotetext{
${ }^{234}$ Consigna o autor: "Que sentido terá, porém, considerar imputáveis e capazes de culpa todos estes delinquentes (pessoa e concretamente incapazes de uma motivação de acordo com a norma), se a teoria da imputabilidade for só, como quer a tese em exame, parte não autônoma da verificação da existência global de uma unitária capacidade de motivação de acordo com a norma? Para quê a preocupação doutrinal e legislativa de traçar os fundamentos biopsicológicos da teoria da imputabilidade, se decisivo para a afirmação ou negação da culpa haverá de ser sempre e só o efeito normativo requerido, a capacidade de avaliar a ilicitude e de se determinar de acordo com aquela avaliação? A conclusão é a de que esta tese acaba pura e simplesmente por fazer tábua rasa do fundamento biopsicológico, não consegue explicar sua necessidade e a sua ligação ao elemento normativo e, com tudo isto, ameaça os fundamentos da teoria da imputabilidade e torna vão todo o esforço para a erguer: ela teria na sua base, afinal, um problema falso ou tão só aparente.”. Id. Ibid., p. 68-69.

${ }^{235}$ Id. Ibid., p. 92-101.
} 
pelo fato antecipada", tratando-se, portanto, de um "dever responder pelo próprio caráter",236

Já a "culpabilidade na decisão de vida" de BocKELMANN, distingue-se da construção de MEZGER essencialmente por se referir a certo momento em que se manifesta o caráter total do agente. Imputa-se ao agente o seu caráter com base em uma decisão de sua vida em que optou pelo "mal”. Superou-se, com isso, a criticada distinção dos componentes culposos e não culposos do caráter.

No que se refere à concepção de LANGE, de "culpabilidade do agente", essa se fundamenta numa omissão, consistente no "poder ser outro", ou seja, por não ter o autor de um fato delitivo feito de si aquilo que era possível segundo sua personalidade. Volta-se, mais uma vez, a um modelo de homem, aqui não referido a uma atuação concreta, mas a uma possível manifestação da personalidade que lhe era exigível ${ }^{237}$.

Outros rumos, contudo, podem ser observados em construções da culpabilidade voltadas para o caráter do agente. Nesse sentido, a busca por uma "legitimidade ética" nessa "culpabilidade pela personalidade" é a essência da concepção de FIGUEIREDO DIAS. Para ele, a prática delitiva é manifestação de uma personalidade que, valorada consoante as qualidades pessoais supostas pelo ordenamento jurídico, é tida por reprovável. Ainda que construído sobre um fundamento axiológico e ético, tal ideia de culpabilidade perpetua-se como teoria balizada pelo "poder atuar de outra maneira", voltando-se agora, contudo, para a valoração do caráter, e não apenas do fato específico, responsabilizando-se pela personalidade que se manifestou na opção pela prática criminosa ${ }^{238}$ Sua culpabilidade, contudo, não se restringe a isso, na medida em que também é necessário um ato de

\footnotetext{
${ }^{236}$ JAKOBS, Günther. Derecho Penal..., p. 591-592. E, para o autor, é impossível distinguir entre as qualidades da pessoa recebidas fatidicamente e aquelas que são adquiridas culpavelmente. SCHÖNEBORN, G. A., 1975, p. 272- 275. apud JAKOBS, Günther, Derecho Penal..., p. 592.

${ }^{237}$ Para FIGUEIREDO DIAS, essa generalização do "poder se formar de outro modo" é verticalizada, no sentido de que se verifica aquilo que se podia exigir do agente segundo sua personalidade, não o comparando com terceiros. FIGUEIREDO DIAS, Jorge. op. cit, p. 105. Não nos parece, contudo, haver essa "real verticalização", posto que, presumir-se que o agente não fez de si aquilo que lhe era possível segundo sua personalidade, significa, em verdade, estabelecer um modelo genérico de conformação da personalidade, no sentido de que, todos os agentes dotados de certos caracteres de personalidade terão, necessariamente, a capacidade de atuar de certo modo. De qualquer forma, então, não se pode negar que, ainda que considerada a situação pessoal do agente (de sua personalidade), haverá uma ficção nos parâmetros de valoração dessa personalidade para determinar qual o agir que the era requerido.

${ }^{238}$ Afirma FigUEIREDO DiAs: "O decisivo não está, como agora se deixa ver, em qualquer alteração fundamental do pensamento da culpa nas suas relações com a vontade livre: ainda aqui a culpa reside em uma viciosa utilização (contra o dever) do livre-arbítrio, do poder agir de outra maneira. O essencial está antes em que este "poder de agir" se não refere agora imediatamente ao facto praticado, mas a um substrato muito mais amplo: a formação do carácter que o fundamenta.”. Id. Ibid., p. 89.
} 
comunicação pessoal entre o juiz e o acusado que permita o acesso e a compreensão da personalidade do agente. É interessante notar que, para FIGUEIREDO DIAS, não há, com a adoção do critério do caráter, o abandono da valoração da "culpa do fato", mas um novo ângulo de análise desta última. $\mathrm{O}$ fato praticado remanesce como substrato formal da culpabilidade, mas, materialmente, a vontade livre se referirá a um subtrato mais amplo, à própria formação do caráter. Pensa o referido autor que, dessa forma, dá-se maior amplitude ao substrato material da culpabilidade, de maneira a aproximá-lo das "exigências do dever social a que tem de responder um direito penal da culpa" "239. Em suma, para ele, a culpabilidade é "a violação pelo homem do dever de conformar o seu existir por forma a que, na sua atuação na vida, não viole ou ponha em perigo bens juridicamente (jurídico-penalmente) protegidos" $240 \mathrm{e}$, materialmente, é o "ter que responder pela personalidade que fundamenta um fato ilícito-típico", observando que a liberdade realizada no fato é idêntica à liberdade da pessoa, constituindo o seu modo de $\operatorname{ser}^{241}$.

Muitas objeções são formuladas a essas concepções materiais de culpabilidade. Percebe-se, em primeiro lugar, que se está reprovando a pessoa por algo pelo qual não é responsável, na medida em que se imputa a culpabilidade por uma conformação da vida, sendo-lhe impossível modificar um dado de seu caráter. E eventuais justificativas metafísicas surgidas para defender esta formulação da culpabilidade recaem no mesmo problema determinista, posto que falar de uma liberdade de eleição de um caráter inteligível, ou de uma escolha fundamental que estabelece o ser, é apenas tentar, fictamente, afirmar a possibilidade do indivíduo eleger aquilo que é, sem se determinar como e quando se dá essa eleição ${ }^{242}$.

Tal fundamento da culpabilidade, em verdade, representa sua própria negativa, uma vez que se estará reduzindo o Direito Penal a fins preventivos fundados numa responsabilidade social ${ }^{243}$.

\footnotetext{
${ }^{239}$ Id. Ibid., p. 91.

${ }^{240}$ Id. Ibid., p. $160-161$.

${ }^{241}$ Id. Ibid., p. 165.

${ }^{242}$ ROXIN, Claus. Derecho penal..., p. 801.

${ }^{243}$ Sobre isso, afirma RoXIN: "El mejor camino para sostener una concepción de la culpabilidad que proclama el deber responder por la propria condición del ser es desde luego el de renunciar totalmente a la retribuición y al reproche moral contra el sujeto, reducir el Derecho penal a finalidades preventivas y entender la culpabilidade más en el sentido de una responsabilidad social. El que se pudiera seguir calificando a sus presupuestos de "culpabilidad" y a tal consecuencia jurídica de "pena" sería más uma cuestión terminológica.". Id. Ibid., p. 803.
} 
Note-se, também, que por essa concepção não se vislumbra uma não culpabilidade do inimputável, na medida em que atuam também conforme seu modo de ser. Para FIGUEIREDO DiAs, os casos de inimputabilidade não demonstrariam uma ausência de culpabilidade, mas a inacessibilidade dela pelo juiz, pela inexistência do ato comunicacional entre o acusado e este julgador ${ }^{244}$. Contudo, tal acréscimo em sua teoria não a exime de críticas, posto que a comunicação e acessibilidade continuam sendo algo não objetivamente constatável.

Por outro lado, consoante sublinha Roxin, mesmo nos casos de inimputabilidade, como na menoridade, não se pode dizer que não há acessibilidade à manifestação da personalidade, não constituindo isso justificativa hábil para se afastar um juízo de culpabilidade ${ }^{245}$.

\subsubsection{A culpabilidade como quebra de fidelidade ao Direito}

Nesta concepção, podem-se inserir as ideias que fundam o conteúdo material da culpabilidade na infidelidade ao Direito. Nesse sentido, temos a concepção jakobsiana funcional de culpabilidade, fundada numa atribuição preventiva geral. $\mathrm{O}$ conceito de culpabilidade, assim, tem seu conteúdo definido por seu fim, entendido como a prevenção geral, não como intimidação, mas como exercício de fidelidade ao Direito. A atribuição de culpabilidade e, consequentemente, de pena, teria o fim de estabilizar a confiança na norma que fora negada pela conduta delituosa.

\footnotetext{
${ }^{244}$ Afirma assim o autor: "[...] a anomalia psíquica, não em todas as suas forma e graus, mas em todo o caso nas mais graves - nas"doenças" mentais ou psicoses e nas mais anómalas perturbações da actividade anímica - torna a total personalidade completamente indivisível à compreensão estranha e exclui, com isto, toda a possibilidade de sobre ela se emitir um juízo de valor. Nesta impossibilidade de "compreensão da personalidade que se exprime no facto se baseia o juízo de inimputabildiade jurídico-penal. Não se trata pois na imputabilidade, nem de uma supressão da relação de fundamentação do facto na personalidade, nem muito menos de uma supressão da liberdade e da consequente responsabilidade geral do inimputável: este continua a ser uma pessoa e portanto da deter a "capacidade" de fundamentar os factos por si próprio praticados e de responder por eles. Do que se trata é antes e tão só da impossibilidade para o juiz de compreender o facto como facto de uma pessoa e, consequentemente, de emitir qualquer juízo de valor sobre a personalidade que nele se exprime. Neste sentido poderia mesmo dizer-se - sem que daqui porém devam tirar-se quaisquer ilações dogmáticas - que a inimputabilidade constitui, antes que uma autêntica causa de "exclusão" da culpa, um obstáculo à efectivação do juízo de censura que aquela traduz: não podendo o juiz "compreender" o facto como facto de uma pessoa, não pode também determinar a existência de qualquer desconformação entre a personalidade que naquele se exprime e a suposta pela ordem jurídica.”. DIAS, Jorge de Figueiredo. op. cit., p. $188-189$.

${ }^{245}$ ROXIN, Claus. Derecho penal..., p. 814.
} 
Por outro lado, de forma semelhante, a culpabilidade comunitária de URS KINDHAUSER trilha caminho semelhante, posto que, conquanto se afaste da neutralidade do Direito contida na formulação estritamente sistêmica de JAKOBS, ressaltando a virtude cidadã como conteúdo de obediência à norma, persegue, da mesma forma, a deslealdade do comportamento do autor em face do ordenamento jurídico ${ }^{246}$.

A questão que se coloca é que tal concepção abandona o caráter limitador do jus puniendi estatal exercido pela culpabilidade, na medida em que a punibilidade do agente não se funda em circunstâncias que residem nele próprio, mas no que seria necessário para se alcançar uma pretensa fidelidade social ao Direito. Nessa perspectiva, instrumentaliza-se o sujeito, fazendo com que um juízo de reprovação penal possa recair sobre ele com fundamento em interesses sociais. Desse modo, circunstâncias pessoais, como a incapacidade de autocontrole, em nada refletem sobre a culpabilidade o agente, posto que sua responsabilização se fundará em razões sociais, consistente na estabilização da confiança ao direito.

Deve-se, ainda, questionar como se pode definir o que seria necessário a essa pretensa estabilização do direito, que soa arbitrária e acaba sendo deixada ao alvedrio legislativo ou judicial, negando o próprio caráter preventivo geral da pena, posto que a sanção será destinada conforme interesses circunstanciais, e não por fatores relativos ao indivíduo e ao seu comportamento.

\subsubsection{A culpabilidade como atuação injusta em face de uma norma exequível}

Por esta percepção, a culpabilidade é entendia como uma conduta injusta, a despeito da possibilidade de exequibilidade da norma, entendida como existência de uma condição psíquica que torna possível a escolha de um comportamento em conformidade com a norma. Apesar de se fundar essencialmente na capacidade do sujeito eleger uma conduta em face do que lhe era exigido pela norma, no que poderia parecer se aproximar das teorias motivacionais da culpabilidade, em muito se distingue dessas. Deve-se ter em

\footnotetext{
${ }^{246}$ MACHADO, Fabio Guedes de Paula. Culpabilidade..., p. 163-165. KINDHÄUSER, Urs. La fidelidad al derecho como categoria de la culpabilidad. In: FRANCO, Alberto Silva; NUCCI, Guilherme de Souza. Doutrinas Essenciais: Direito Penal,v. 3, Parte Geral 2. São Paulo: Revista dos Tribunais, 2010, p. 10341036.
} 
mente que a concepção de culpabilidade agora analisada não se funda no livre arbítrio, posto que não se embasa na possibilidade do agente atuar de outro modo, mas numa asserção normativa que supõe a liberdade individual (não como metafísica, mas como uma regra social, de tratamento do direito perante todos os indivíduos, tal como ocorre com o princípio da igualdade ${ }^{247}$ ) e, por conseguinte, a capacidade de controlar-se e comportar-se conforme a norma. Diante de tal concepção, não precisa o Direito Penal tomar partido por qualquer teoria filosófica.

Por essa concepção, defendida por RoxIN, a culpabilidade compõe-se por uma faceta empírica e outra normativa. A capacidade geral de autocontrole e a exequibilidade normativa seriam passíveis de comprovação empírica. De forma diversa, dependeria de atribuição normativa a possibilidade de conduta conforme o direito. Não legitima, assim, uma reprovação moral, ao afastar os questionamentos sobre o poder atuar de outro modo, fundamentando apenas uma responsabilidade por uma conduta social incorreta ${ }^{248}$, restringindo o Direito Penal ao que seja socialmente indispensável.

Perceba-se que, com base nessa teoria, quando se tem que, pelas circunstâncias da situação, ou pelo estado mental ou anímico do sujeito, era-lhe impossível determinar-se conforme o Direito, não há porque dirigir-lhe um juízo de reprovação penal, posto que não houve, por tal conduta, uma negação do poder motivacional da norma em face da sociedade. Restringe-se, assim, o exercício do jus puniendi estatal ao absolutamente necessário, afastando seu caráter puramente preventivo.

Esse conceito de culpabilidade funda-se, então, na justificação social da pena, se assemelhando, nesse ponto, às concepções de culpabilidade pelo caráter e de culpabilidade funcional, diferenciando-se, contudo, por afirmar ao máximo o caráter limitador do princípio da culpabilidade, não o atrelando às necessidades de prevenção geral ou especial mutáveis, mas à capacidade de controle do sujeito, o que seria empiricamente demonstrável.

Há, contudo, críticas a essa suposição normativa de liberdade, feitas por autores como SCHÜNEMANN, GRIFFEL e KAUFFMAN, todos, em certo sentido, afirmando a indemonstrabilidade da liberdade (livre arbítrio), mas a impossibilidade de seu questionamento como algo real.

\footnotetext{
${ }^{247}$ ROXIN, Claus. Derecho Penal..., p. 808.

${ }^{248}$ Id. Ibid., p. 810.
} 


\subsubsection{Negação da culpabilidade}

Não se pode olvidar, ainda, de posicionamentos na doutrina no sentido do abandono do princípio da culpabilidade como fundamento do Direito Penal, sob o argumento de que seria inútil, sobretudo em face de sua indeterminação. Nesse sentido, pode-se apontar MICHAEL BAURMANN ${ }^{249}$, para quem o juízo de reprovação penal poderia se fundar na exequibilidade normativa, afastando-se questões metafísicas sobre a personalidade, e também WALTER KARGL ${ }^{250}$, para quem o Direito Penal deveria ter esteio nas instituições jurídico-constitucionais básicas ${ }^{251}$.

Ressalta, contudo, RoxIN, que tais autores olvidam da presença de tais critérios na própria culpabilidade, segundo sua formulação, ressaltando que a exequibilidade normativa faz parte da culpabilidade, e que a culpabilidade é derivada do princípio da dignidade humana previsto constitucionalmente ${ }^{252}$. As propostas formuladas rechaçando a culpabilidade não são, então, capazes de fornecer ao Direito Penal o caráter de garantia para o acusado, muito menos de satisfazer as exigências de justiça que devem ser derivadas do exercício do poder punitivo estatal, quer em face do autor do delito, quer em face da sociedade ${ }^{253}$.

\subsection{Aproximações entre a "culpabilidade individual" e uma possível "culpabilidade do ente coletivo"}

Delineadas, sem pretensões exaustivas, as principais teorias informadoras da “culpabilidade individual”, pode-se dizer que, no estágio atual da doutrina, não se conseguiu precisar de forma unívoca o que deveria constituir a culpabilidade jurídico-penal

\footnotetext{
${ }^{249}$ BAURMANN, Zweckrationalität und Strafrecht, 1987. apud JESCHECK, Hans-Heinrich. Evolução do conceito..., p. 17.

${ }^{250}$ KARGL, Kritik des Schuldprinzips - eine rechtssoziologische Studie zum Strafrecht, 1982. apud Id. Ibid., p. 16.

${ }^{251}$ Sobre o tema, ver, também, ROXIN,Claus. Derecho Penal..., p. 812.

${ }^{252}$ Id. Ibid., p. 813.

${ }^{253}$ Essa constatação é feita por JESCHECK, para quem tais propostas “[...]próprias del mundo imaginario de la abolición del Derecho penal, propuestas que no son capaces de sustituir las garantías que este ofrece alafectado ni de satisfacer lãs exigências de justicia del autor ni del conjunto de la población.”. JESCHECK, Hans-Heinrich. Evolução do conceito..., p. 17.
} 
neste campo. Muito além da imprecisão terminológica também constatada ${ }^{254}$, a questão que se coloca como essencial à culpabilidade individual moderna relaciona-se à fundamentação material da imputação de reprovação penal por um fato ilícito ao seu autor.

O reconhecimento desta problematização da culpabilidade, ainda nos estritos limites da responsabilidade da pessoa física, revela-se, em diversos aspectos, como importante para a análise das diversas teorias voltadas para uma possível construção de uma culpabilidade voltada para a pessoa jurídica ou de um conceito equivalente.

Em primeiro lugar, essa problematização nos permite reconhecer que alterações dogmáticas são inerentes ao discurso evolutivo do direito penal, que não se cinge nem é inaugurado pela admissão de uma nova forma de responsabilidade criminal, como parecem fazer crer aqueles que repudiam o reconhecimento da pessoa jurídica como agente delitivo. Perceba-se que, no estrito campo da culpabilidade individual, verifica-se o advento de teorias propondo a readaptação dos critérios dogmáticos para tentar solucionar as dificuldades em se determinar essa culpabilidade. Assim ocorreu, por exemplo, com o finalismo, ao redesenhar a estrutura do delito, revolucionando o esquema dogmático penal até então vigente; de igual modo, a teoria da atribuibilidade, ao inserir um elemento (a responsabilidade pelo fato) entre a antijuridicidade e a culpabilidade; ou mesmo a construção funcionalista de RoxIN, que torna a culpabilidade um subelemento de uma nova categoria dogmática (a responsabilidade). Essas redefinições estruturais, por mais que criticadas e contestadas, não traduzem o abandono da culpabilidade ou seu desvirtuamento. Devem ser avaliadas, em verdade, consoante sua adequação às respostas que pretendem dar, sem preconceitos dogmáticos a negar-lhes qualquer contribuição. É com esse olhar, também, que devemos encarar a culpabilidade na responsabilidade penal da pessoa jurídica, despidos de preconceitos e desapegados aos dogmas estruturais, sem abandono, é bem verdade, dos fundamentos principiológicos básicos que orientam o Direito Penal, em especial a dignidade da pessoa humana e a limitação do poder punitivo estatal.

De outra banda, a leitura das diversas teorias da culpabilidade individual nos permite reconhecer que a questão essencial que se coloca, de certa maneira, identifica-se com o problema que também se tentará solucionar com eventual construção da

\footnotetext{
${ }^{254}$ Nesse sentido, rememorar o posicionamento de MIR PUIG, que afirma que "a doutrina está de acordo que o fato antijurídico deve poder ser imputado ao seu autor. Entretanto, as opiniões se dividem tanto em relação à terminologia adequada para expressar essa ideia, como em relação às condições de tal imputação". MIR PUIG, Santiago. Direito Penal..., p. 409.
} 
culpabilidade da pessoa jurídica, problema muito bem traduzido por FIGUEIREDO DIAS, qual seja, a tarefa de "saber se, com uma tal 'verdade' ou 'hipótese de trabalho', se alcança, no domínio do direito penal, um conceito de culpa que responda vitoriosamente às exigências que lhe são feitas, por maneira tal que possa dizer-se que a aceitação daquela verdade ou hipótese é irrenunciável para o direito penal"255. Não se olvida, contudo, que a problemática da culpabilidade da pessoa jurídica vai mais além, por exigir a adaptação do Direito Penal também em sua natureza, posto que construído voltando-se para a ação humana. Essa peculiaridade, contudo, não torna a questão (e é isso que pretende se enfatizar nesse momento) completamente alheia ao problema que também coloca a culpabilidade individual, ainda que as soluções possam não ser unívocas - ou seja, ainda que a hipótese de trabalho e, consequentemente, o conceito de culpabilidade construído não seja único. Por mais que sejam reconhecidas como "categorias autônomas", deve-se ter em mente, como bem esclareceu SÉRGIO SALOMÃo SHECAIRA, que a responsabilidade penal da pessoa jurídica terá suas raízes no princípio da culpabilidade ${ }^{256}$.

De maneira mais pontual - e revelando argumentos mais concretos para o trabalho com a culpabilidade da pessoa jurídica -, pode-se dizer que a análise da culpabilidade individual até agora empreendida, permitiu-nos verificar a construção de parâmetros ficcionais (abstratos) para a determinação do conteúdo da culpabilidade, muitas vezes fundados em critérios sociais, conquanto buscassem se voltar para uma possível "vontade" do sujeito. Assim, por exemplo, ao falar-se na culpabilidade como atitude interna do indivíduo (evidenciando, ao máximo, o caráter humano desse elemento do crime e, consequentemente, do Direito Penal) recorre-se à cultura social para reconhecer a liberdade de escolha humana (GALLAS), ou à "cognoscibilidade social" (JESCHECK) para dotar de conteúdo o juízo de valor emanado pela culpabilidade. Mesmo alguns autores que reconhecem a indemonstrabilidade do livre-arbítrio humano, mas afirmam a impossibilidade de seu questionamento como algo real, fundam tal conclusão afirmando ser ele "socialmente real", por estar assentado nas estruturas elementares da nossa

\footnotetext{
${ }^{255}$ FIGUEIREDO DIAS, Jorge de. op. cit,, p. 57.

${ }^{256}$ Assim afirma o autor: "De tudo quanto foi dito, especialmente do caráter de interesse público dado à pena, para aquele que pratica um delito, com seus pontos de semelhança e de dessemelhança entre responsabilidade individual e coletiva, é que podemos passar para a discussão da responsabilidade penal da pessoa jurídica. No entanto, sempre é bom lembrar que esta, embora tenha uma disciplina própria que permita identificá-la como categoria autônoma, tem sua sraízes no princípio da culpabilidade, assim como o direito público que surge posteriormente ao direito privado (e de certa forma, do direito privado), mas com ele mantém uma interrelação.”. SHECAIRA, Sergio Salomão. Responsabilidade penal..., p. 85.
} 
comunicação social - o que nos parece ser adaptável à pessoa jurídica, como veremos mais à frente. Nas teorias funcionalistas (sobretudo em JAKOBS), as expectativas sociais constituem critério para a avaliação da relevância comunicativa da ação do autor, que é repudiada não por ser uma manifestação interna desvalorada, mas por demonstrar um déficit de fidelidade à norma. Percebe-se, portanto, que mesmo na culpabilidade individual - e, mais ainda, mesmo na culpabilidade fundada, de certa forma, na liberdade humana recorre-se a categorias sociais sem que com isso haja o desvirtuamento da culpabilidade. Assim, parece-nos que o "substrato psicológico" que tantos argumentam ser imprescindível à configuração da culpabilidade ${ }^{257}$, tem se mostrado cada vez mais apoiado em categorias sociais para tentar superar sua indemonstrabilidade. Talvez seja isso o próprio reflexo da alteração conceitual da responsabilidade, que não se liga mais à liberdade de escolha e à noção de imputabilidade, mas, agora, ao compromisso com a alteridade e, portanto, atrelado à ideia de solidariedade ${ }^{258}$. De tal modo, pensa-se que nem a ausência desse conteúdo psicológico na pessoa jurídica, muito menos o repúdio às construções sociais, por assim dizer, poderão servir como argumentos hábeis a refutar, por si só, uma possível culpabilidade da pessoa jurídica.

Outro ponto de suma importância à análise que se empreenderá da culpabilidade do ente coletivo - e que se pode vislumbrar já nas iniciais teorias da culpabilidade - consistirá no apego à distinção entre juízo de valoração e objeto. Essa distinção, iniciada desde o pré-finalismo, ao reconhecer a culpabilidade como juízo de valoração cujo objeto seria o dolo, teve grande importância na depuração dos elementos da culpabilidade e no posterior desenvolvimento das teorias sobre tal tema, sobretudo com relação à busca de um conteúdo material a fundar esse juízo valorativo. Pensa-se que tal distinção será um duplo desafio na construção da culpabilidade da pessoa jurídica,

\footnotetext{
${ }^{257}$ Nesse sentido, afirma BERNARDO JosÉ FEIJOO SÁNCHEZ que "los requisitos de la culpabilidade em nuestro Código Penal tiene un substrato psicológico del que no se pude prescindir (responsabilidad subjetiva - dolo o imprudencia - conocimiento de la antijuridicidad, exigibilidad del cumplimiento de la norma).” FEIJÓO SÁNCHEZ, Bernardo José. Sanciones..., p. 68.

${ }^{258}$ Assim constata JORGE DOS REIS BRAVO: "Mais recentemente, a concepção dominante de responsabilidade não decorre essencialmente de uma escolha livre, antes, consiste num compromisso, como uma atribuição de que se é depositário. O indivíduo não é já erigido em sujeito isolado e em confronto consigo mesmo, mas decorre da condição humana uma partilha da existência em comunidade, assumindo a característica da alteridade uma qualidade constituinte da própria (inter-)subjectividade, que se faz presente entre todos os homens. A responsabilidade, sem dela prescindir, supera, pois, a noção de imputabilidade, aparecendo uma evidente componente ética ou, mais limitadamente, uma noção de solidariedade. São destacados precursores desta concepção - embora nisso consista o único ponto comum dos respectivos sistemas de reflexão filosófica -, Emmanuel Lévinas e Hans Jonas, os quais, propondo embora sistemas de compreensão distintos, convergem no reconhecimento da dimensão da alteridade na responsabilidade". BRAVO, Jorge dos Reis. Direito Penal..., p. 25.
} 
porquanto demandará reconhecer-se o objeto a ser valorado (e que apresentará a dificuldade de se delinear a ação da pessoa jurídica que, como se sabe, não será produto da vontade, pelo menos não no sentido tomado do agir humano) e o conteúdo do juízo de valoração (o como se reprova), até como forma de se repudiar a responsabilidade penal objetiva $^{259}$.

Não se descurará, ademais, que, assim como nas críticas levantadas para as teorias que negavam a necessidade de uma culpabilidade individual, deve-se questionar se as formulações de conceitos equivalentes em substituição à culpabilidade para as pessoas jurídicas não perderão as funções garantísticas (essencialmente, de limitação do poder punitivo e ponderação da pena) inerentes a este elemento.

Em síntese, podemos dizer que a leitura acurada das mais diversas teses procurando responder às indagações sobre a imputação subjetiva, no específico campo da culpabilidade individual, com todas as suas controvérsias, permite-nos verificar que esse caminho não linear, que por vezes retorna às teorias antecedentes, demonstra o recurso a conceitos abstratos, fictícios, presuntivos, muitas vezes justificados por critérios sociais, e a busca, nas teorias contemporâneas, de responder a exigências de política criminal ou a demandas sociais de estabilização. Se dessa forma tem se encaminhado a culpabilidade individual, indagar-se ou construir-se uma culpabilidade dos entes coletivos não seria negar a natureza e a função da culpabilidade que, a bem da verdade, parece, no seu âmbito individual, vir se aproximando de concepções que não se revelam completamente incompatíveis ou destoantes de um possível juízo de imputação subjetiva voltada para os entes coletivos.

Presente essas considerações, pensa-se ser possível passar à análise das especificidades das construções teóricas relacionadas a uma possível culpabilidade da pessoa jurídica.

\footnotetext{
${ }^{259}$ Nesse sentido, é importante salientar a crítica feita por FEIJOO SÁNCHEZ, analisando sentença do Tribunal Supremo espanhol (STC 246/1991, de 19 de dezembro) que trata do princípio da culpabilidade no âmbito do Direito Administrativo Sancionador para pessoas jurídicas. Dentre os argumentos trazidos pelo autor para se refutar a possibilidade dessa formulação atender as exigências do princípio jurídico-penal de culpabilidade, afirma-se que há confusão entre a infração objetiva da norma e a culpabilidade, remetendo-se, em certa medida, ao strict liability anglo-saxão. FEIJÓO SÁNCHEZ, Bernardo José. Sanciones..., p. 60-62. Em certa medida, também, constrói sua crítica à proposta de Tiedemann de uma "responsabilidade da pessoa jurídica por defeito de organização" com o mesmo argumento, salientando que há a equiparação da culpabilidade com o tipo objetivo "ya que la realización de los elementos objetivos del tipo por parte de algún miembro de la empresa opera iuris et de iuri contra la persona jurídica (responsabilidad objetiva)." Id. Ibid., p. 70-71.
} 


\section{MODELOS DE RESPONSABILIDADE DA PESSOA JURÍDICA E A CORRELAÇÃO ENTRE AÇÃO E CULPABILIDADE}

A identificação de modelos de responsabilidade da pessoa jurídica pela doutrina tem refletido, em grande medida, a assunção, sem maiores debates, de uma convergência entre a modalidade de imputação de ação e a modalidade de apuração da culpabilidade $^{260}$. Esta leitura, contudo, restringe as possibilidades teóricas de aplicação de eventuais modelos de culpabilidade relacionados à responsabilização penal da pessoa jurídica. Remete, também, a uma imprecisão na delimitação do objeto do juízo de culpabilidade, tomando-o como a própria ação imputada à pessoa jurídica.

Parece-nos importante, então, como pressuposto teórico para a apuração da culpabilidade da pessoa jurídica, tentar desmistificar essa "conexão necessária", tão amplamente difundida na doutrina, entre modelos de imputação de ação e modelos de apuração de culpabilidade, permitindo, assim, uma maior ampliação argumentativa sobre a aplicação dos modelos teóricos de culpabilidade e deixando, dessa forma, eventuais constatações de incompatibilidades teóricas entre as modalidades de imputação de ação e de determinação de culpabilidade para a apuração concreta, não fundada em raciocínios presuntivos.

Para tanto, faz-se necessário, inicialmente, identificar os modelos de atribuição de responsabilidade, tal como delineados pela doutrina, para depois tentar efetuar essa cisão entre modelos de imputação de ação e modelos de apuração de culpabilidade.

\subsection{Modelos de responsabilidade}

A construção de modelos de atribuição de responsabilidade penal às pessoas jurídicas revela a discussão inerente à própria admissão dessa responsabilidade, que consiste em considerar a pessoa jurídica como ente autônomo dotado, por si só, de capacidades para se fazer penalmente reprovável, ou como ente de existência dependente

\footnotetext{
${ }^{260}$ Esse diagnóstico pode ser percebido na obra coletiva "Série pensando o direito - responsabilidade penal da pessoa jurídica". Nela os autores asseveram que "em princípio, todos os modelos de ação das coletividades podem ser conjugados com qualquer um dos modelos de apuração de culpabilidade. No entanto, da forma como vêm sendo debatidos, os modelos de ação individual apresentam-se conjugados a formas de apuração de culpabilidade igualmente individuais". BRASIL. Ministério da Justiça. Secretaria de Assuntos Legislativos. Série Pensando o Direito: responsabilidade penal da pessoa jurídica. n. 18, 2009. p. 31. Disponível em: <portal.mj.gov.br/main.asp?view=\{329D6EB2-8AB0-4606-B054-4CAD3C53EE73\}>. Acesso em: 15 jul. 2011.
} 
da composição por indivíduos e, por isso mesmo, cuja reprovação penal só poderá advir se estritamente conectada a um comportamento humano.

É nessa dualidade de pensamentos que se constroem os dois grandes modelos de atribuição de responsabilidade: o modelo de responsabilidade indireta e de responsabilidade direta.

A adoção dessa nomenclatura e a divisão dual não é, contudo, uniforme na doutrina. Dentro de cada uma dessas modalidades é possível vislumbrar a identificação de outros modelos de imputação, por vezes tratados como idênticos, por vezes delineados em seus pontos de divergência. Assim, por exemplo, no modelo de responsabilidade indireta é possível relacionar o sistema vicarial, bem como a teoria do alter ego, as quais podem ser tratadas como idênticas ou não por alguns autores ${ }^{261}$.

Parece-nos, contudo, ser suficiente a identificação dessas duas grandes vias, abrindo espaço, contudo, para que nelas se possa estabelecer algumas distinções doutrinárias em relação a outras modalidades específicas, as quais poderão ser caracterizadas no bojo de uma categoria teórica mais ampla por apresentarem semelhanças em sua essência que permitem tal identificação.

\subsubsection{Modelo de responsabilidade indireta}

Por esta modalidade de atribuição de responsabilidade há a necessidade de se apurar o delito de uma pessoa física componente do ente coletivo para, assim, imputar a este último a responsabilidade penal. Há uma transferência, por ficção jurídica ${ }^{262}$, da responsabilidade originada pelo fato praticado por uma pessoa física situada na estrutura organizativa da empresa à própria empresa. A relação funcional existente entre o indivíduo que pratica efetivamente o ato e a pessoa jurídica justificaria essa "ficção jurídica" de se

\footnotetext{
${ }^{261}$ Nesse sentido, para ZULGADíA ESPINAR, por exemplo, o modelo de responsabilidade indireta, o sistema vicarial e a teoria do alter ego são tratados como sinônimos. ZULGADÍA ESPINAR, José Miguel. La responsabilidade..., p. 141. SILVA SÁNCHEZ denomina a responsabilidade indireta como "responsabilidade por atribuição", reconhecendo a teoria do alter ego (ou doutrina da identificação) como uma construção destinada a evitar as críticas de que se trataria de uma "responsabilidade pelo fato de outro". SILVA SÁNCHEZ, Jesús-María. Normas... p. 70-73. Interessante, também, é a distinção efetuada por JUAN MARÍA DEL SEL entre a responsabilidade vicária e a teoria do alter ego, remetendo à origem histórica de tal diferenciação. SEL, Juan María del. Societas delinquere, ¿potest o non potest? La responsabilidad criminal de la empresa a la luz de la visión anglosajona. In: YACOBUCCI, Guillermo J. (dir.). Derecho penal empresário. Montevidéu: B. de F., 2010, p. 100-101.

${ }^{262}$ Assim afirma HeFENDEHL: "[...] tal simples modelo de imputación no es más que una ficción: La atribuición de la acción de alguien más a la corporación no es sinónimo com una acción de la corporación, ni es la atribuición de la culpabilidad de alguien mas a la corporación sinónimo com una determinación de la culpabilidad de la corporación.”. HEFENDEHL, Roland. La responsabilidade..., p. 423.
} 
transferir a responsabilidade de um para o outro.

Por outro lado, essa relação funcional justifica, também, o dever de vigilância da empresa, posto que a ela se imputará, inclusive, as omissões dos componentes de sua estrutura $^{263}$.

Esse transporte da responsabilização depende não apenas de que o delito seja praticado (comissiva ou omissivamente) por um sujeito componente da estrutura empresarial. Dogmaticamente, erigiram-se alguns critérios para a transferência dessa responsabilidade da pessoa física para a jurídica, como forma, até, de revelar uma "conexão material" (e não meramente ficcional), por assim dizer, entre a conduta do(s) indivíduo(s) componente(s) da estrutura empresarial e a imputação de responsabilidade à pessoa jurídica. Afirma-se, assim, que a ação ou omissão humana deve se revelar no exercício da função ao indivíduo atribuída na estrutura empresarial e destinar-se a um favorecimento da empresa, nunca próprio ou de terceiros ${ }^{264}$.

A limitação na transposição da responsabilidade entre pessoa física e jurídica é que permite, também, trazer à tona a diferenciação entre o modelo de responsabilidade vicarial e a teoria do alter ego. Essa distinção, surgida no âmbito do direito anglo-saxônico, iniciou-se com a extensão da categoria de delitos que poderiam ser cometidos pela pessoa jurídica, extensão essa que permitiu englobar os crimes que exigiam intencionalidade, o que não era admitido até o final do século $\mathrm{XIX}^{265}$. A inclusão deste elemento subjetivo desencadeou evoluções teóricas díspares, entre Estados Unidos e Inglaterra, na definição da responsabilidade penal da pessoa jurídica ${ }^{266}$.

Nos Estados Unidos, a expansão do espectro de responsabilidade penal da pessoa jurídica foi mais ampla, comparando-se com o modelo britânico. Os americanos, até em busca de uma maior regulação das empresas, em face da grande expansão de tais entes em seu território, passaram a admitir a imputação de delitos intencionais às pessoas jurídicas, responsabilização essa que poderia ser derivada da ação de qualquer funcionário componente da estrutura empresarial. É o chamado "modelo de responsabilidade vicária", modalidade de responsabilização com um conteúdo muito próximo da teoria civilista da responsabilidade pelo fato de outrem, contida em nosso ordenamento jurídico nos artigos

\footnotetext{
${ }^{263}$ Sobre isso, SILVA SÁNCHEZ, Jesús-María. Normas..., p. 71.

${ }^{264}$ KREMNITZER, Mordechai; GHANAYIM, Khalid. Die Strafbarkeit von Unternehmen. In: In: Zeitschrift für die gesamte Strafrechtswissenschaft, v.113, 2001, p. 542-543. apud BRASIL. Ministério da Justiça. Secretaria de Assuntos Legislativos. Série Pensando o Direito - Responsabilidade penal da pessoa jurídica, p. 34.

${ }^{265}$ Cf. SEL, Juan María del. op. cit., p. 100.

${ }^{266}$ Cf. VERVAELE, John A. E. La responsabilidad..., p. 470-471.
} 


\section{2 e 933 do Código Civil ${ }^{267}$.}

É interessante observar que essa admissão de responsabilidade penal da pessoa jurídica por crimes intencionais se deu num específico caso julgado pela Suprema Corte relacionado à aplicação de uma lei (Ley Elkins de 1903) ${ }^{268}$ que prevía expressamente a vontade do Congresso de responsabilizar as empresas pela ação de seus componentes. Contudo, essa interpretação foi estendida pelos tribunais inferiores, aplicando-a aos delitos que podiam ser cometidos por qualquer pessoa ${ }^{269}$. Segundo JUAN MARÍA DEL SEL, aliás, o último estágio dessa evolução se deu com a admissão da responsabilização penal dos entes coletivos quer por delitos com dolo geral, como por aqueles que requerem um elemento subjetivo específico ${ }^{270}$.

$\mathrm{Na}$ Inglaterra, a admissão da responsabilidade das empresas por delitos intencionais foi limitada pelo desenvolvimento da teoria do alter $e g o^{271}$. Inspirada na doutrina dos ilícitos civis, por tal teoria limita-se a responsabilização das empresas aos atos derivados de uma classe específica de indivíduos que compõem a estrutura empresarial, quais sejam, os ocupantes dos cargos diretivos ou superiores (diretores e gerentes) da pessoa jurídica. Entende-se que, nesses casos, a atitude e a intenção criminal de tais agentes confundem-se com a da própria pessoa jurídica, de forma que a responsabilização desta não se trata de uma responsabilização derivada, imputada, mas, em certa medida, uma responsabilização própria, no sentido de que o que o órgão pratica só pode ser

\footnotetext{
${ }^{267} \mathrm{O}$ artigo 932 do Código Civil dispõe, em cinco incisos, quais serão os "também responsáveis pela reparação civil", esclarecendo o articulado seguinte que "as pessoas indicadas nos incisos I a V do artigo antecedente, ainda que não haja culpa de sua parte, responderão pelos atos praticados pelos terceiros ali referidos".

${ }^{268}$ Afirma JuAn MARía DEL SEL: "En lo concerniente a delitos intencionales y a la aceptación de la responsabilidad vicariante como base para su atribuición, el leading case fue la decisión de la Suprema Corte en el fallo "New York Central \& Hudson River R. R. v. United States", de 1909. En él se cuestionaba la constitucinalidad de las normas de la Ley Elkins de 1903, ya que ésta preveía específicamente la responsabilidad vicariante al tener una norma que atribuía a la corporación los actos y las omisiones de sus empleados ejecutados en el ámbito de sua trabajo.”. SEL, Juan María del. Societas delinquere..., p. 102.

${ }^{269}$ Esclarece DEL SEL: "Pese a que este caso trataba sobre una ley qye expresamente preveía la intención del Congreso de atribuirle responsabilidad criminal a la persona jurídica por la actuación de sus empleados en el marco de sus empleos, la manera en que la Corte Suprema redactó el fallo permitió a los tribunales inferiores hacer una lectura amplia y expansiva de sua holding, a punto tal que, por un lado, comenzó a interpretarse que cualquier ley qye establezca genéricamente que el delito pude ser cometido por "cualquier persona" incluye también a las personas jurídicas y, por otro lado, la decisión dio pie a que se elimine la distinción entre los delitos inherentemente malos por la naturaleza de la conducta ("delitos mala per se") y los delitos de creación estatutaria.". Id. Ibid., p. 104

${ }^{270}$ Consigna o mencionado autor: "El último avance en esta senda fue la eliminación de la diferencia en el tratamiento entre delitos cometidos con dolo general y delitos que requieren un elemento subjetivo específico en su tipo penal.”. Idem, p. 104

${ }^{271}$ Segundo VeRVAELE "[...] en Gran Bretaña se sigue insistiendo en la teoría limitada de "l' alter ego" o teorpia del órgano. En el marco de la responsabilidad por infracciones "mens rea", sólo los actos o la amisión en la gestión ('the corporation's brain') pueden conducir a la responsabilidad penal de la persona jurídica". VERVAELE, John A. E. La responsabilidade..., p. 471.
} 
reconhecido como a ação do corpo como um todo, numa verdadeira equiparação com a estrutura orgânica do corpo humano. Por isso, também, diz-se que o desenvolvimento de tal teoria teria a finalidade de superar as críticas $^{272}$ de que um modelo de responsabilidade indireta (ou vicária) se traduziria na admissão de uma responsabilidade pelo fato de outro $^{273}$.

É bem verdade que essa teoria, por si só, não teve o condão de definir quais seriam esses agentes específicos e qual a posição ocupada por eles na estrutura empresarial, para que suas ações pudessem vincular a empresa e torná-la penalmente responsável. Para isso, desenvolveu-se, jurisprudencialmente, a fórmula do controlling officer test ${ }^{274}$, de maneira que o agente capaz de vincular a pessoa jurídica seria aquele que pudesse ser identificado como o "cérebro" da empresa, dotado de uma independência funcional que lhe permitiria desempenhar as atividades e decisões inerentes à seu cargo, sem se submeter a outro comando nesse específico aspecto.

De qualquer modo, sob uma ou outra nomenclatura (responsabilidade vicária ou teoria do alter ego), e mesmo tendo-se em mente as peculiaridades de cada modelo, é indubitável que apresentam uma essência comum, partindo sempre da apuração da conduta dos componentes humanos da pessoa jurídica (limitados ou não a uma certa posição funcional) para cogitar sobre a responsabilidade penal desse ente coletivo. Assim, são tais modalidades, com suas distinções, apenas fórmulas específicas de adoção de um modelo de responsabilidade indireta, o que permitiu que muitos autores não formulassem diferenciações ao tratar do tema ${ }^{275}$.

Esse modelo de responsabilização indireta teria como ponto favorável a facilidade de superação das objeções dogmáticas normalmente colocadas à

\footnotetext{
${ }^{272}$ SILVA SÁNCHEZ, Jesús-María. Normas..., p. 72.

${ }^{273}$ Assim afirma FEIJOO SÁNCHEZ, ao tratar da teoria da representação ou modelo de imputação (vicarious liability): "Con este tipo de fundamentaciones no se há logrado todavía, en mi opinión, superar el inconveniente de que la culpabilidad de las personas juridicas acaba siendo siempre culpabilidad por el hecho de outro.". FEIJÓO SANCHEZ, Bernardo. Sanciones..., p. 56.

${ }^{274}$ Esclarece JUAN MARÍA DEL SEL que este critério foi estabelecido jurisprudencialmente na Inglaterra num famoso caso de 1972, denominado "Tesco Supermarkets Ltd. v. Natrass". Neste caso, a empresa era acusada da conduta ilícita de um dos gerentes de suas sucursais e se estabeleceu que tal agente não poderia ser considerado como a própria empresa, de forma que a solução absolutória foi adotada. SEL, Juan María del. Societas delinquere..., p. 101.

${ }^{275}$ Podemos apontar alguns autores que parecem não operar tal distinção.: MACHADO, Fabio Guedes de Paula. Reminiscências da responsabilidade penal da pessoa jurídica. In: FRANCO, Alberto Silva; NUCCI, Guilherme de Souza (org.). Doutrinas essenciais: Direito Penal. v. 3. Parte Geral 2, São Paulo: Revista dos Tribunais, 2010, p. 373; ZULGADÍA ESPINAR, José Miguel. La responsabilidad ..., p. 141; HEINE, Günter. La responsabilidad..., p. 57-59. Em certa medida também, tratando de forma única sob a nomeclatura de "modelo de responsabilidade por atribuição”, SILVA SÁNCHEZ, Jesús María, Normas..., p. 70-73
} 
responsabilidade penal da pessoa jurídica pela doutrina clássica ${ }^{276}$, ao se transferir ação e culpabilidade da pessoa física à pessoa jurídica, não demandando, portanto, maiores esforços para a adaptação do modelo dogmático da teoria do crime às peculiaridades do ente coletivo $^{277}$. As críticas teóricas, contudo, se deslocaram a outros pontos.

Em primeiro lugar, as dificuldades argumentativas passam a girar em torno da fundamentação dessa transferência de responsabilidade ${ }^{278}$. Diz-se, aliás, que há nela a expressão de uma verdadeira admissão, no campo penal, de responsabilidade pelo fato de outro $^{279}$, crítica essa que, como se disse, pretendeu-se superar por meio da construção da teoria do alter ego. Permanecem, contudo, as objeções ligadas à constatação de que a promoção de uma "imputação normativa" do comportamento individual para o entre coletivo, traduzir-se-ia, em verdade, numa "imputação objetiva" insuficiente ao Direito Penal $^{280}$.

De outro banda, parece indubitável não haver um verdadeiro enfrentamento das questões atinentes aos déficits subjetivos das pessoas jurídicas quando apenas se transfere tais elementos dos indivíduos para os entes coletivos ${ }^{281}$. De igual modo, critica-se a dificuldade de se atribuir responsabilidade nos casos em que não se identifica pessoa física autora, o que é plenamente factível em estruturas empresarias complexas, dotadas de divisão de tarefas e diferenciação funcional, em que, muitas vezes, o advento de um risco ou de um dano só se dará com o transcurso de um longo lapso temporal, tornando ainda mais difícil a imputação à atitude de uma pessoa específica ${ }^{282}$. Tenta-se, aliás, resolver tal

\footnotetext{
${ }^{276}$ Consigna Roth: "Los problemas de penalidad se plantean en los mismos términos en el marco de los dos modelos. Por el contrario, los otros problemas de puro princípio, aún de pura dogmática, se plantean de manera más aguda en el marco del modelo directo que en ele del modelo vicarial. El primero incita a hacer prueba de imaginación jurídica para establecer la capacidad delictiva de las personas jurídicas o empresas y, sobre todo, para calificar el tipo de reproche (o de "culpabilidad") que puede serles directamente formulado [...]”. ROTH, Roberth. Responsabilidad..., p. 192.

${ }^{277}$ Nesse sentido, afirma SILVA SÁNCHEZ: “[...] es cierto que el modelo expuesto elude com bastante facilidad los obstáculos que, desde la teoría clásica del delito, se arguyen contra la calificación de la persona jurídica como "sujeto" de la infracción. En efecto, al partir de que el órgano ha cometido el delito de modo completo, lo decisivo en ella es la fundamentación político-criminal y dogmática de la "transferencia" de responsabilidad a la persona jurídica.”. SILVA SÁNCHEZ, Jesús-María. Normas..., p. 72.

${ }^{278}$ Segundo SILVA SÁNCHEZ, "Lo que queda abierto en todo caso, para este modelo, es, la cuestión del título en cuya virtud la responsabilidad por ese hecho puede ser transferida a la persona jurídica.". Id. Ibid., p. 70.

${ }^{279}$ FEIJÓO SANCHEZ, Bernardo José. Sanciones..., p. 56.

${ }^{280}$ Citando KÖHLER e JAKOBS, afirma SILVA SÁNCHEZ que "tal imputación 'normativa' del comportamiento individual 'como proprio del grupo' se reduce a una mera imputación objetiva, que podría ser suficiente para la imposición de consecuencias jurídico-civiles o de Derecho público, pero no precisamente para la culpabilidad subjetiva y la pena". SILVA SÁNCHEZ, Jesús-Maria, Normas..., p. 77. De igual modo, FeIJóo SÁNCHEZ consigna que "el traslado directo de la responsabilidad penal del representante al representado [...] resulta contrario a los principio del Derecho Penal Moderno.”. FEIJÓO SÁNCHEZ, Bernardo José. Sanciones..., p. 58.

${ }^{281}$ SILVA SÁNCHEZ, Jesús-Maria, Normas..., p. 77.

${ }^{282}$ Afirma HEINE: "Este modelo de imputación funciona de manera aceptable en el caso de las pequeñas
} 
problema de maneira pragmática, invertendo-se a carga probatória (ou seja, havendo a prática de determinados delitos no bojo empresarial, presumir-se-ia que a conduta partiu de alguma pessoa física componente da estrutura do ente coletivo, sendo possível a responsabilização da pessoa jurídica, a qual só poderia ser afastada se comprovado que o dano ou risco não partiu da ação de seus integrantes, dependendo-se, assim, de uma prova negativa para afastar a responsabilidade), como ocorre na legislação japonesa ${ }^{283}$. Salientase, também, como problema desse modelo, a ausência de solução relativa à responsabilização penal das pessoas jurídicas nas hipóteses em que a pessoa física atua de modo inculpável ${ }^{284}$. Diante de tais ponderações, revela-se a desvinculação da responsabilização penal da pessoa jurídica de um de seus argumentos de política criminal, qual seja, o de enfrentar a "irresponsabilidade organizada".

Por outro lado, afirma-se que esse modelo de imputação pode abrir espaço para "situações de esquizofrenia", ao permitir, por exemplo, que "representantes vinculem a sociedade, mesmo atuando contra a vontade social ou havendo realizado um comportamento proibido pela sociedade"285. Perceba-se que os critérios de "conexão material" anteriormente referidos não se apresentam como solução hábil ao deslinde de tal problema, na medida em que é possível que, no exercício da função inerente a seu cargo e favorecendo a empresa, um indivíduo componente da estrutura empresarial possa atuar

empresas que tienen una estructura jerárquica lineal y en las que el máximo responsable posee integralmente la competencia y la información. Esta concepción de la imputación resultaba adecuada en los albores de la industrialización. Pero, con el crecimiento de las empresas los problemas se han multiplicado. Las modernas formas de organización, con una diferenciación funcional y una división de las tareas estratégicas y operacionales (lean management), hacen difícil que se detecte la responsabilidad de las personas naturales. Sobre todo al interior de las empresas, se generam continuamente nuevos riesgos que, típicamente sólo se desarrollan con el tiempo. Su conversión en perturbaciones sociales no es debida, con frecuencia, a la decisión de una sola persona sino al desarrollo defectuoso de la empresa. De esto modo, tan solo con el paso de los años, las decisiones individuales llegan a crear graves riesgos si que se pueda establecer penalmente una culpabildad individual (lo impide el principio de coincidencia).”. HEINE, Günther. La responsabilidad..., p. 58.

${ }^{283}$ Cf. Idem, p. 58-59. Ver também, tratando do tema, TIEDEMANN, Klaus. Nuevas tendencias..., p. 408409. Essa presunção, aliás, assemelha-se com a solução exposta por ROTH, citando ERHARDT, A., para quem o modelo vicarial poderia ser salvo com a complementação de que o julgador deve estabelecer, ao apurar a responsabilidade penal da pessoa jurídica, que o ato que produziu o risco ou o dano só poderia ter partido da atuação de um dos componentes da empresa, ou seja, efetuando-se um raciocínio presuntivo. ERHARDT, A. Unternehmensdelinquenz und Unternehmensstrafe. Berlin: 1994, p. 343. apud ROTH, Roberth. Responsabilidad..., p. 205.

${ }^{284}$ Para SILVA SÁNCHEZ tal questão é irresolúvel "pese a los intentos de superarlo y, de algún modo, pone de relieve la inconveniencia de la mezcla que produce el modelo de responsabilidad transferida entre los niveles individual y supraindividual de imputación”. SILVA SÁNCHEZ, Jesus-María. Normas..., p. 73. Para KREMNITZER e GHANAYIM expressam uma forma de exculpação da pessoa jurídica. KREMNITZER, Mordechai; GHANAYIM, Khalid. Die Strafbarkeit von Unternehmen. In: Zeitschrift für die gesamte Strafrechtswissenschaft, v. 113, 2001, p. 556. apud BRASIL. Ministério da Justiça. Secretaria de Assuntos Legislativos. Série Pensando o Direito - Responsabilidade penal da pessoa jurídica, p. 34

${ }^{285}$ Nesse sentido, FEIJÓO SANCHEZ, Bernardo Jose. Sanciones..., p. 58 
contrariamente a uma decisão social específica, sem que com isso, por exemplo, sua conduta exceda os limites do objeto social (sem configurar até mesmo, portanto, um ato ultra vires societatis em tal conduta, excluindo-se, assim, inclusive sua responsabilidade civil pessoal) ${ }^{286}$.

Ressalta-se, também, que se admitida uma responsabilização penal cumulativa entre pessoa física e jurídica neste modelo de imputação, estar-se-ia incorrendo em verdadeiro bis in idem ao se sancionar, por uma única ação antijurídica (e mesmo, por uma única culpabilidade, para aqueles que entendem que, neste modelo, há sempre identidade de culpabilidades, com a transferência deste elemento do indivíduo para o ente coletivo que compõe), pessoas diversas ${ }^{287}$.

Outro ponto crítico de tal teoria é que, em busca de uma ampliação da responsabilidade penal da pessoa jurídica, amplia-se a responsabilidade penal individual, o que acaba conduzindo a uma equiparação dessas duas formas de responsabilidade ${ }^{288}$.

Como se disse, é recorrente na doutrina o reconhecimento de que, neste modelo de imputação há a transferência não só da ação, mas também da culpabilidade do indivíduo para a pessoa jurídica, como se houvesse uma conexão necessária entre estes dois âmbitos de transferência. Desse modo, bastaria a apuração da culpabilidade de seu componente para que o ente coletivo tivesse também configurada a culpabilidade capaz de ensejar sua responsabilização penal ${ }^{289}$. Essa leitura, contudo, conduziria a que muitos modelos legislativos existentes, em que se faz menção à necessidade de constatação da conduta delitiva de um indivíduo componente da estrutura empresarial para que se pudesse

\footnotetext{
${ }^{286}$ Sobre os atos ultra vires societatis, conferir o artigo 158, inciso II, da Lei 6040/76.

${ }^{287}$ Sobre isso, afirma FEIJóo SÁNCHEZ: "Este modelo de solución tiene también serios problemas con el principio ne bis in idem en la medida que se imponen dos penas a dos personas distintas (representante y representado) por la misma acción antijurídica y la misma decisión culpable. Es más, el representante o el órgano es castigado dos vezes: una por su própria acción culpable y otra como parte de la persona colectiva.". FEIJÓO SÁNCHEZ, Bernardo José. Sanciones... p. 59. Por esta razão, também, SILVA SÁNCHEZ entende que este modelo só albergaria sistemas de responsabilidade alternativa. Consigna o aludido autor: "Este modelo abona, a mi entender, sistemas de responsabilidad alternativa más que cumulativa. Y, en esa medida, no fundamenta satisfactoriamente la posibilidad de sancionar tanto al órgano como a la persona jurídica; en realidad, desde la perspectiva que propone, habría que afirmar que existe un único hecho de un único sujeto, el del órgano, de modo que la doble sanción incurriría en un bis in idem.” SILVA SÁNCHEZ, Jesús-María. Normas..., p. 71.

${ }^{288}$ Sobre isso, ver: HEINE, Günther. La responsabilidad..., p. 59. Ver, também, ZULGADÍA ESPINAR, José Miguel. La responsabilidad..., p. 142.

${ }^{289}$ Perceba-se, por exemplo, que ROTH, apesar de reconhecer que, no modelo vicarial, a questão da responsabilização se aborda em dois tempos, um da avaliação da ação da pessoa física componente da estrutura empresarial, e outro da imputação à pessoa jurídica, entende que neste segundo momento transferese ao ente coletivo não só a ação do indivíduo, mas também o juízo de reprovação que este comportamento individual suscita (p. 190). Tanto é assim que, mais à frente consigna, que "en el marco del modelo vicarial, por el contrario, sólo existe responsabilidad bajo dos condiciones: el reconcimiento de la culpabilidad y la imputación subsigiente de ésta a la empresa.” (p. 201). ROTH, Robert. Responsabilidad..., p. 190 e 201.
} 
configurar a responsabilidade penal da pessoa jurídica, não pudessem ser compatibilizados com modelos teóricos de culpabilidade próprios dos entes coletivos.

\subsubsection{Modelo de responsabilidade direta}

Neste modelo, haveria a revelação do grande desafio da responsabilidade penal da pessoa jurídica, que é a identificação, nas atividades próprias das pessoas jurídicas, dos elementos da categoria do crime ${ }^{290}$. Volta-se as preocupações a um comportamento próprio da empresa para destinar-lhe uma reprovação penal ${ }^{291}$, inexistindo a transferência fictícia de qualquer elemento humano (ação, culpa etc.) para o ente coletivo. Fala-se, portanto, em uma responsabilidade autônoma, sem que, com isso, se afaste a responsabilidade individual $^{292}$.

Sua origem remonta à dificuldade das teorias antecedentes em lidar com os casos em que não havia identificação de autoria individual por pessoa física, bem como em se adequarem ao tratamento da estrutura das grandes empresas (principais protagonistas dessa nova realidade social de criminalidade difusa que trouxe à tona a discussão sobre a necessidade de uma responsabilidade penal dos entes coletivos), cujas ações e decisões, na maioria das vezes, não podem ser individualizadas, por serem construídas no seio de uma atividade organizada e coletiva, não afetas, portanto, ao comportamento de uma única pessoa $^{293}$.

Nessa modalidade de responsabilização haveria, assim, a apuração de uma ação

\footnotetext{
${ }^{290}$ SILVA SÁNCHEZ, Jesús-María. Normas..., p. 77-78.

${ }^{291}$ Segundo RoTH: "En el modelo directo, el juez, llamado a pronunciarse sobre la responsabilidad de la empresa o de la persona jurídica, se manifiesta sobre el comportamiento de ésta sin pronunciarse, necesariamente, sobre el comportamiento de una persona física”. ROTH, Robert. Responsabilidad..., p. 190.

${ }^{292}$ Importante assinalar, neste ponto, que para FEIJÓO SÁNCHEZ, para se fundamentar uma responsabilidade (e culpabilidade) própria da pessoa jurídica, dever-se-ia dispensar a responsabilidade individual nos casos em que aquela primeira é aplicada. Afirma o autor: "En el Derecho privado siempre se há aceptado la responsabilidad colectiva bajo el siguiente axioma: quod universitas debet, singuli non debent. En Derecho Penal se debe partir del axioma de que la culpabilidad no puede estar integrada por otras culpabilidades. Por tanto, la culpabilidad individual excluye la colectiva, así como esta excluye aquélla. Si se quiere tomar en serio la entidad, identidad, consciência o personalidad colectiva (corporate actor) - institucionalizada en muchos casos como personalidad jurídica, el Derecho Penal debe prescindir de la responsabilidad individual en el ámbito de la criminalidad de empresas y personas jurídicas. Formulado en termos sistémicos, se debería interpretar que los representantes y órganos no actúan como personas (en clave individual) sino como representantes u órganos del sistema por lo que sólo se pueden impuatr las acciones o comunicaciones al sistema en su conjunto. Cuanto más autonomía se le concede a un sistema, más heterógenos son sus integrantes individuales. [...] La referencia argumentativa a ordenamiento de Derecho comparado que contemplan ambos tipos de responsabilidad debe tener en cuenta que esos ordenamientos parten, de forma implicita o explícita, del modelo de la representación.”. FEIJÓO SÁNCHEZ, Bernardo José. Sanciones..., p. 66.

${ }^{293}$ SILVA SÁNCHEZ, Jesús-Maria. Normas...., p. 74-75.
} 
própria da pessoa jurídica e de uma culpabilidade também sua, o que demandaria a construção de uma teoria do delito própria desse ente coletivo ${ }^{294}$.

Aponta a doutrina a existência de diversos sistemas a embasar o modelo de responsabilidade direta. Pelo "sistema do fato de referência"295 não se abandona a consideração do comportamento da pessoa física. Este consistirá o substrato material da responsabilidade da pessoa jurídica, demandando a existência de critérios normativos para que a ação do indivíduo componente da estrutura empresarial e que realiza a vertente objetiva do tipo penal (o fato de referência), seja imputada à pessoa jurídica, apurando-se sua própria culpabilidade. Afirma-se que tal sistema se distingue dos modelos indiretos de responsabilização porque não há a transferência da ação da pessoa física para a pessoa jurídica que nada praticou, muito menos a equiparação, como se a conduta de uma fosse a de outra ${ }^{296}$. Voltam-se os olhares para a definição de critérios normativos que permitam atribuir o fato de referência como próprio da pessoa jurídica, quer na apuração do ilícito, quer na culpabilidade, ambos com um caráter específico para o ente coletivo, não se confundindo com a apuração de tais elementos em relação à pessoa física.

Já pelos sistemas funcionalistas ${ }^{297}$, em tese não se perquire sobre qualquer fato relacionado às pessoas físicas componentes do ente coletivo. A responsabilização penal da pessoa jurídica adquire seu grau máximo de autonomia, concebendo-se um sistema que gravita em torno, exclusivamente, deste ente ${ }^{298}$.

\footnotetext{
${ }^{294}$ Esclarece ZULGADÍA ESPINAR: “[...]la persona jurídica debe responder por su propia acción y por su propia culpabilidad desde un modelo directo en el que sea posible manifestarse sobre el comportamiento de la persona jurídica sin pronunciarse, necesariamente, sobre el comportamiento de una persona física, ya que la mirada solo es dirigida el agente individual o colectivo - órgano o representante - en tanto que es emanación de la entidad ("teoría de la persona jurídica responsable" en la terminología de Huber). Para estabelecer esta responsabilidad criminal directa de la persona jurídica es necesario construir una teoría jurídica del delito de la persona jurídica paralela a la teoría jurídica del delito de la persona física, lo que suela hacerse siempre redefiniendo las caregorías de esta última.". ZULGADÍA ESPINAR, José Miguel. La responsabilidad..., p. $142-143$.

${ }^{295}$ Id. Ibid., p. 143-146.

${ }^{296}$ Afirma ESPINAR: "No se trata de "transferir"lo que há hecho una persona (la persona física) a outra que no lo há hecho (persona jurídica). Ni siquiera se trata de poder afirmar que el hecho cometido por una persona (la persona física) equivale jurídica o axiológicamente a su realización por otra persona (la persona juridica). Se trata de determinar bajo qué condiciones normativas se puede atribuir directamente el hecho a la persona jurídica como próprio, como su autora. Por eso es importante no incorrir en construcciones que se orientan hacia un sistema de responsabilidad criminal indirecta de la persona jurídica y que hacen girar el problema en torno a la forma de conectar - atribuir, poner a cargo - la conducta de la persona física a la persona jurídica aunque esta no sea su autora". Id. Ibid., p. 143-144.

${ }^{297}$ Importante ressaltar que JOSÉ MIGUEL ZULGADíA ESPINAR faz uso do termo "sistemas funcionalistas" no plural (cf. Id. Ibid., p 146). Indica, com isso, a existência de construções teóricas diversas, mas que, por uma semelhança (no caso, a de conceber uma responsabilidade penal da pessoa jurídica a margem da pessoa física), permitem que sejam classificadas como integradoras de um sistema único dentro do modelo de responsabilização direita.
}

${ }^{298}$ Id. Ibid., p. 146-151. 


\subsection{Algumas considerações sobre os modelos de responsabilização}

Teoricamente, é de se observar que mesmo a doutrina vacila, em certos momentos, na caracterização de tais modelos. Nem sempre as teorias são bem definidas dentro de uma ou outra modalidade de imputação, seja pela confusão semântica na utilização dos termos classificatórios, seja por divergências interpretativas.

Veja-se, por exemplo, a teoria da identificação. HEINE a explica sem classificála como componente de um modelo de responsabilização direta ou indireta ${ }^{299}$. Contudo, constrói uma crítica a essa teoria ${ }^{300}$ que é utilizada por ZULGADÍA ESPINAR para rechaçar o modelo indireto de imputação ${ }^{301}$, dando a entender este último autor, assim, que a teoria da identificação se trata de uma modalidade de responsabilidade indireta (derivada da pessoa física). Com isso, aliás, parece concordar SILVA SÁNCHEZ ao equiparar a teoria da identificação com a teoria do alter ego ${ }^{302}$, caracterizando-as como modalidades de responsabilidade por atribuição. Contudo, RоTH, ao explanar a origem da teoria da identificação no direito inglês, assevera que esta surgiu a partir do direito marítimo como um modelo direto de responsabilização ${ }^{303}$. Aliás, cita decisão jurisprudencial em que se opõe a teoria da identificação à teoria do alter ego ${ }^{304}$. Todavia, consigna, em nota de

\footnotetext{
${ }^{299}$ Para HeINE, há três modelos básicos de responsabilidade penal, e em um deles "una corporación debe ser identificada com las personas que de manera activa son responsables por ella". Nesse modelo o ato do órgão é entendido como ação incorreta da empresa e "el hilo conductor es la clásica teoría de la identificación". Além desse modelo, para o autor há um segundo baseado na organização deficiente da corporação e um terceiro modelo fundado no princípio da causalidade. HEINE, Günther. La responsabilidad..., p.57.

${ }^{300}$ Afirma HeINE: “[...] esta concepción de la responsabilidad lleva cada vez más al legislador y a losz tribunales a ampliar la responsabilidad de las personas naturales.”. Id. Ibid., p. 59

${ }^{301}$ Ressalta ESPINAR, ao tratar do modelo de responsabilidade indireta ou sistema vicarial que: "Aparte de otros inconvenientes a los que se hará referencia mas adelantes (constitucionales, dogmáticos, etc.), destaca em este sistema el de tender a ampliar la responsabilidad de las personas naturales o físicas para garantizar la responsabilidad criminal de las personas jurídicas ("cuanto mas extensa sea la responsabilidad individual, tanto mayor será la responsabilidad de la agrupación”).”. Faz menção, em nota de rodapé, à mesma crítica trazida por HEINE. ZULGADÍA ESPINAR, José Miguel. La responsabilidad..., p. 141-142.

${ }^{302}$ Afirma SILVA SÁNCHEZ, ao tratar do modelo de responsabilidade "por atribuição": "En efecto, al partir de que el órgano há cometido el delito de modo completo, lo decisivo em ella es la fundamentación políticocriminal y dogmática de la "transferencia" de responsabilidad a la persona jurídica. Y para evitar la crítica de que se trataría de una responsabilidad por un hecho de otro es precisamente para lo que se construye la teoría de la identificación o del "alter ego".”. SILVA SÁNCHEZ, Jesús-Maria. Normas..., p. 72.


vicarial, há desarrollado, a partir del derecho marítimo, un modelo directo com la teoría de la identificación.”. ROTH, Roberth. Responsabilidad..., p. 191.

${ }^{304}$ Afirma ROTH: "El alcance de la expresión identificación y del cambio que la substituición de términos indica bajo al ángulo de los modelos está bien ilustrada por los argumentos de Lord Reid en el contexto de una de las decisiones de principio esenciales, Tesco Supermarket Ltd. V. Nattrass: "En algunos casos, la expresión alter ego há sido utilizada... Respecto a una empresa, pienso que el término alter es equivoco. Ella es identificada a la sociedad... Las personas físicas representan para la sociedad el medio por lo que
} 
rodapé, que efetivamente há a confusão semântica no uso do vocábulo "identificação" por existir tanto o sentido advindo desse modelo inglês, como também o de origem francesa, em que há a procura pela pessoa física componente da estrutura empresarial cuja conduta comprometa a pessoa jurídica ${ }^{305}$.

Percebe-se, também, uma divergência interpretativa na classificação do sistema do fato de referência. ZULGADÍA ESPINAR o expõe como uma variante do modelo direito de responsabilidade $^{306}$. Na doutrina nacional, FÁBIO GUEDES DE PAULA MACHADO, conquanto traga no bojo de sua explanação sobre a responsabilidade direta os comentários feitos por ESPINAR com relação ao fato de referência, trata especificamente desse sistema num tópico autônomo àqueles relativos ao modelo de responsabilidade indireta e direita ${ }^{307}$.

Esses exemplos trazidos, ao que se pensa, permitem abrir espaço para que se possa enxergar tais classificações não como delineamentos exatos e imutáveis de relação entre a apuração da ação e a apuração da culpabilidade da pessoa física e jurídica. Parece não haver uma relação de necessidade entre tais tópicos de apuração que demandem uma análise conjunta da ação e culpabilidade da pessoa natural transferidas à pessoa moral, e, de outro lado, da ação e culpabilidade próprias da pessoa jurídica. Aliás, a própria distinção entre modelo indireto e direito de responsabilidade parece imprecisa, havendo, por vezes, superposição e sucessão desses modelos num mesmo ordenamento jurídico ${ }^{308}$.

Ressalte-se, todavia, que não se está aqui a negar valia aos critérios classificatórios tão difundidos doutrinariamente, os quais, ao que se pensa, tem o mérito de revelar os benefícios e dificuldades de se buscar uma caracterização de uma responsabilidade própria e autônoma da pessoa jurídica. A bem da verdade, quando se pretende (como é o caso) efetuar uma análise acurada da culpabilidade da pessoa jurídica (ou de possíveis orientações alternativas à sua apuração), pensa-se que não se pode, desde logo, cingir o objeto de estudo a certas interpretações pré-constituídas pela doutrina. Quer-

actúan.”.”. Id. Ibid., p. 191.

${ }^{305}$ ROTH faz tal esclarecimento na nota de rodapé de n. 40, em que consigna: "El vocabulario utilizado puede desgraciadamente provocar confusión (semántica) en la materia que ya es en sí difícil. En efecto, el término "identificación" há sido recepcionado y se há difundido a partir del modelo inglés, y debo utilizarlo aquí. Será, así mismo después, de otro tipo de identificación en un sentido francés más correcto, tratándose de la búsqueda de la persona física cuyos actos (y omissiones) comprometen la responsabilidad de la empresa". Id. Ibid., p. 191.

${ }^{306}$ ZULGADÍA ESPINAR, José Miguel. La responsabilidad..., p. 143.

${ }^{307}$ MACHADO, Fábio Guedes de Paula. Reminiscências ..., p. 372-374.

${ }^{308}$ É o que constata ROTH ao tratar da diferenciação entre os modelos de responsabilidade. Afirma que esta distinção pode parecer clara, a priori, mas é imprecisa, e um dos fundamentos de sua imprecisão é justamento o fato de que "los sistemas se superponen y hasta se suceden a veces en el mismo orden jurídico.". ROTH, Roberth. Responsabilidad..., p. 190-191. 
se com isso dizer que - e talvez melhor esclarecendo - se, já no limiar de nossa análise, deixarmos ao largo a possibilidade, por exemplo, de um certo modelo legislativo exigir a verificação da conduta humana para que um delito possa ser imputado à pessoa jurídica mas compatibilizar-se, doutrinariamente, esta exigência legislativa a um modelo teórico de culpabilidade própria da pessoa jurídica, restringiríamos o objeto de estudo do presente trabalho e sua aplicabilidade concreta sem o aprofundamento necessário das discussões sobre o tema.

Tais considerações nos parecem conectas à própria definição do objeto da culpabilidade.

\subsection{O objeto da culpabilidade e a possibilidade de conjugação de modelos teóricos diversos}

É possível utilizar a classificação dogmática exposta para se diferenciar o objeto de valoração da culpabilidade em duas modalidades. Um, derivado do agir humano, situação em que teremos uma responsabilização indireta, transferida da pessoa física para a pessoa jurídica. Outro, em que se apurará uma culpabilidade (ou responsabilidade, dependendo da teoria adotada) própria da pessoa jurídica.

Parece-nos perceptível que, nos casos em que o objeto da culpabilidade que fundará a responsabilidade penal da pessoa jurídica derivar de uma valoração da conduta humana, a apuração dessa conduta será de rigor, posto que sem ela o juízo de reprovação penal não poderá ser realizado. Essa fórmula se compatibiliza perfeitamente com a estrutura vicarial de responsabilização, no sentido de que haverá dois tempos de avaliação: inicialmente, apura-se o comportamento da pessoa física e a reprovação (culpabilidade) que suscita; posteriormente, atribui-se tal comportamento já valorado à pessoa jurídica ${ }^{309}$.

Já no que se refere à apuração de uma culpabilidade própria da pessoa jurídica, crê-se haver, pelo menos em tese, a possibilidade de sua compatibilização quer com modelos que exijam a apuração de uma conduta prévia da pessoa física, quer com modalidades em que se busca apurar apenas uma "conduta" autônoma do ente coletivo. No primeiro caso, é plausível pensarmos em um modelo legislativo em que se faça a exigência da apuração da conduta de um componente da estrutura empresarial, mas em que a atribuição à pessoa jurídica se restrinja ao comportamento humano neutro, ou seja, sem

\footnotetext{
${ }^{309}$ Id. Ibid., p. 190.
} 
que sobre ele incidisse qualquer juízo valorativo. Tal juízo se efetuaria num segundo momento, relacionado exclusivamente à pessoa jurídica, e constituiria uma culpabilidade sua, própria. Bem por isso, ainda que apurada uma conduta humana prévia, esta não será o objeto do juízo de culpabilidade, consistindo numa "condição objetiva" de apuração da responsabilidade penal da pessoa jurídica.

Assim, por exemplo, dever-se-ia apurar, depois de constatada a conduta humana danosa ou perigosa no bojo empresarial, se, por algum motivo (defeito de organização, filosofia empresarial, ou outras causas que iremos analisar mais à frente ao tratar dos modelos de culpabilidade da pessoa jurídica) a empresa pode ser tida como culpável pelo advento daquela conduta. É bem verdade que, em tal hipótese teórica, o trabalho será redobrado. Afinal, demandará a constatação de uma ação humana e de uma posterior atuação da pessoa jurídica sobre a qual recairá o juízo de culpabilidade. Contudo, abre-se uma hipótese que permite compatibilizar eventuais construções doutrinária de uma culpabilidade própria da pessoa jurídica com modelos legislativos já existentes ${ }^{310}$.

Essa constatação não exclui, também, a possibilidade de construções teóricas que prescindam totalmente da apuração de uma conduta humana, responsabilizando-se diretamente (no sentido mais amplo dessa classificação) as pessoas jurídicas. De qualquer modo, ampliado o campo de análise, por meio da percepção da possibilidade de combinações entre modelos de imputação de ação e modelos de culpabilidade diversos, podemos passar à identificação das construções teóricas atinentes à culpabilidade da pessoa jurídica, desapegando-nos de certos preconceitos teóricos.

\footnotetext{
${ }^{310}$ Esta seria uma hipótese teórica a ser aplicada, por exemplo, no modelo brasileiro de responsabilidade penal da pessoa jurídica contido na Lei 9.605/98. Como se sabe, o artigo $3^{\circ}$ de tal legislação estabelece uma relação de necessidade entre a responsabilização da pessoa jurídica e a apuração da conduta delitiva cometida por "decisão de seu representante legal, ou de seu órgão colegiado, no interesse ou benefício de sua entidade". Ainda que se afirme haver a adoção, pela lei brasileira, de um modelo vicarial de responsabilização criminal da pessoa jurídica, parece-nos possível compatibilizar tal modelo com a apuração de uma culpabilidade própria da pessoa jurídica, mesmo que isso torne ainda mais complexa a apuração desta responsabilidade.
} 


\section{A CULPABILIDADE $\mathrm{E}$ A RESPONSABILIDADE PENAL DA PESSOA JURÍDICA: ADAPTAÇÕES DOGMÁTICAS.}

Delineados os pressupostos necessários para uma melhor compreensão geral do tema da responsabilidade penal da pessoa jurídica e das dificuldades inerentes à definição da culpabilidade, antes mesmo de relaciona-la a esse peculiar sujeito, o que se fez observando, inicialmente, os argumentos favoráveis e contrários à admissão dessa responsabilidade penal, determinando a situação legislativa e doutrinária brasileira sobre o tema, bem como tentando desvincular os modelos de responsabilização da forma de apuração de culpabilidade do ente coletivo, pensa-se haver um substrato teórico suficiente para enfrentarmos o desafio de se analisar as diversas construções voltadas para a culpabilidade da pessoa jurídica.

Para tanto, enfrentaremos desde concepções que não pretendem a apuração de uma culpabilidade da pessoa jurídica, ainda relacionando-a à verificação na pessoa física, até os modelos fundados em posições teóricas fundadas numa culpabilidade autônoma da pessoa jurídica, passando, também, pelos equivalente funcionais. Será importante, ademais, visualizarmos as críticas mais recentes a esses modelos teóricos, que negam não só a culpabilidade, mas uma verdadeira responsabilidade de natureza penal da pessoa jurídica, a despeito das previsões legislativas em contrário.

\subsection{Os modelos teóricos}

\subsubsection{Traslado da culpabilidade da pessoa física para a pessoa jurídica}

Uma solução encontrada pela doutrina para justificar a responsabilização penal das empresas, mesmo diante das dificuldades impostas pela tentativa de compatibilização com o princípio da culpabilidade penal, foi a "imputação" da culpabilidade das pessoas físicas componentes da estrutura empresarial a tais entes coletivos, modelo este denominado por FEIJÓo SÁNCHEZ como modelo da imputação ou teoria da representação $(\text { vicarious liability) })^{311}$.

\footnotetext{
${ }^{311}$ Para FEIJÓo SÁNCHEZ há duas grandes vias de solução em relação à culpabilidade na responsabilidade penal da pessoa jurídica: a teoria da representação ou modelo de imputação (vicarius liability) e os modelos de fundamentação e uma culpabilidade própria da pessoa jurídica ou empresa. Não será está distinção dual que adotaremos no presente trabalho. Nesse aspecto, deve-se consignar, também, que a nomenclatura
} 
A bem da verdade, por essa concepção, parece-se reafirmar a incapacidade de culpabilidade da empresa, na medida em que a solução que se busca encontrar direciona-se à apuração da culpabilidade dos indivíduos justificando o sancionamento do ente coletivo que compõem. Essa "pseudo-justificação" revela-se essencialmente formalista, por buscar, de forma tautológica, usar como fundamento aquilo que deveria fundamentar. Afinal, quer se queria ou não, afirma-se que é possível reprovar penalmente a pessoa jurídica porque é possível transferir-lhe a culpabilidade da pessoa física que compõe a ela própria. Em outras palavras, imputa-se pena à pessoa jurídica porque se imputa culpabilidade à pessoa jurídica, sem esclarecer materialmente o fundamento dessa trasladação de culpabilidade, aplicando-se a racionalidade do instituto da representação, próprio do Direito Civil, mas inadequado ao Direito Penal ${ }^{312}$.

Trata-se, aqui, mais de uma relação de causalidade do que de apuração de culpabilidade da pessoa jurídica, posto que, existindo na pessoa física os elementos do crime, constata-se a responsabilidade da pessoa jurídica pela sua atividade, havendo uma relação causal entre a infração penal praticada pelo indivíduo componente da estrutura empresarial e a atividade do ente coletivo ${ }^{313}$.

Esse modelo é tido por CARLOS GÓMEZ-JARA DíEZ como expressão mais conhecida daquilo que denominou de heterorresponsabilidade ${ }^{314}$, por buscar a pessoa

vicarious liability não deve remeter, pelo menos não em sua integralidade, ao modelo de responsabilidade vicarial por nós anteriormente tratado ao discorrer sobre o modelo de responsabilidade indireta (capítulo quarto, item 4.1.1). Naquele momento tratávamos da identidade (acreditamos, equivocada) entre "imputação" de ação e "imputação" de culpabilidade. A classificação de FEIJÓo SÁNCHEZ, entretanto, relaciona-se ao específico aspecto da aplicação do princípio da culpabilidade. Sobre isso, FEIJÓO SÁNCHEZ, Bernardo. Sanciones..., p. 55-60.

${ }^{312}$ Afirma FEIJÓo SÁNCHEZ que: “[...] el traslado directo de la responsabilidade penal del representante al representado (el titular da empresa) resulta contrario a los principio del Derecho Penal moderno. La institución de la representación (vicariuos liability), válida para el Derecho civil, carece de legitimidad en el ámbito del Derecho Penal por ser contraria a los postulados básicos del principio de culpabilidade". Id. Ibid.., p. 58 .

${ }^{313}$ FOFFANI critica este modelo. Para ele: “... la responsabilidade de la persona jurídica está ya demasiado vinculada a la de la persona física, y el mecanismo de imputación es demasiado automático y deja una excessiva descrecionalidad al juez penal.”. FOFFANI, Luigi. Bases para una imputación subjetiva de la persona moral: ¿Hacia una culpabilidad de las personas jurídicas?. In: Dogmática penal del tercer milenio: libro homenaje a los profesores Eugenio Raul Zaffaroni y Klaus Tiedemann. Lima: Ara, 2008, p. 426.

${ }^{314}$ Desde logo, é oportuno esclarecer que sob a classificação "heterorresponsabilidade", CARLOS GóMEZJARA DíEZ inclui modelos muitos distintos. Para ele, todos os modelos que busquem na pessoa humana os elementos da teoria do delito para depois imputá-los ao ente coletivo, consoante determinadas regras de atribuição, seriam modelos de heterorresponsabilidade. Bem por isso, foi possível ao autor incorporar sob esta nomenclatura construções tão distintas como a teoria da representação (responsabilidade vicarial), modelo essencialmente de heterorresponsabilidade, como também modelos por ele classificados como de heterorresponsabilidade, mas apontando tendências a uma "autorresponsabilidade", entre os quais podemos exemplificar a organização de vontade e de consciência de HAFTER, a culpabilidade coletiva e o espírito normativo de associação de BUSCH e a culpabilidade organizativa empresarial, passando, neste último contexto, pela análise de autores como TIEDEMANN, BRENDER e HIRSCH. Cf. GÓMEZ-JARA DÍEZ, Carlos. 
natural atuante em nome da pessoa jurídica para atribuir a culpabilidade daquela a esta. Considera o autor que a proliferação desse modelo se deu pela maior facilidade de se recorrer, para a identificação da culpabilidade, a um sujeito para o qual os elementos do Direito Penal foram desenvolvidos, ou seja, o ser humano. Contudo, o princípio que fundamentaria tal trasladação da culpabilidade não seria admissível, por se fundar num raciocínio de compensação e não jurídico-penal, embasando-se, de forma questionável, a legitimidade dessa transferência, ou seja, da imposição de sanção ao ente coletivo, no fato de que este teria sido beneficiado "pelas atuações delitivas de seus empregados"315.

Por outro lado, é perceptível que a adoção desse critério de "justificação" da culpabilidade torna ainda mais problemática a questão de se compatibilizar a responsabilização da pessoa jurídica com a da pessoa física, posto que, havendo, por tal concepção, uma única culpabilidade, o duplo sancionamento, tanto da pessoa física como da jurídica, consistirá em repudiável bis in idem ${ }^{316}$. No limite, essa formatação de culpabilidade trasladada incorrerá numa irresponsabilidade organizada dos indivíduos componentes da pessoa jurídica, negando-se um dos argumentos políticos-criminais para a adoção da responsabilidade penal empresarial.

Não se pode descurar, ademais, que essa construção permite albergar "situações esquizofrênicas", abrindo espaço para a responsabilização da pessoa jurídica mesmo quando seu representante atue de forma contrária à vontade social ou proibida pela sociedade $^{317}$. Demonstra, ainda, a dissociação entre autoria e responsabilidade, fundamentando uma responsabilidade por fato alheio, o que, para FEIJóo SÁNCHEZ, justificou a não aplicação desse modelo mesmo entre a doutrina anglo-saxã e os partidários da responsabilidade penal das empresas ${ }^{318}$.

La culpabilidad penal de la empresa. Madrid: Marcial Pons, 2005, p. 139 e ss.

${ }^{315}$ Afirma GÓMEZ-JARA DíEZ: "La razón por la cual los modelos de heterorresponsabilidad proliferaron en un principio resulta bastante evidente. Ante las dificuldades que supone tratar com un sujeto para el cual no están diseñadas las categorias del Derecho penal, resilta comprensible que la doctrina haya recurrido a aquel sujeto que sí se adapta perfectamente a dichas categorias: la persona física. La cuestión principal reside aqui en buscar un principio que legitime atribuir a la persona jurídica la culpabilidad de la persona física. El principio que, de manera generalizada, aparece referido constantemente reza como sigue: dado que la empresa resulta beneficiada por las actuaciones delicitivas de sus empleados, es legítimo imponerle uma sanción por ello. Sin embargo, la lógica que late detrá de esta argumentación difícilmente puede considerarse uma lógica jurídico-penal. Más bien parece tratar-se de uma compensación que sigue un esquema benefícios/perdidas y que no pertenece al ámbito próprio del Derecho penal.”. Id. Ibid., p. 141-142.

${ }^{316}$ Id. Ibid., p. 59.

${ }^{317}$ Id. Ibid., p. 58.

${ }^{318}$ Afirma o autor: "[...] cabe rechazar soluciones basadas en la representación o en la imputacín de la culpabilidade individual al ente colectivo porque la persona jurídica acaba respondendo no por su hecho sino por um hecho ajeno. No es extraño que este tipo de modelos hayan sido ampliamente rechazados incluso por parte de la doctrina anglosajona y de autores partidários de la punición de personas jurídicas.”. Id. Ibid., p. 


\subsubsection{A imposição de pena à pessoa jurídica sem culpabilidade: o estado de necessidade do bem jurídico de SCHÜNEMANN}

Na interessante visão de SCHÜNEMANN, o reconhecimento da possibilidade da responsabilidade penal da pessoa jurídica deve demonstrar que não se trata de uma simples “mudança de etiquetas", devendo, para tanto, haver a "elaboração de conceitos dogmáticopenais cuja aplicação seja válida para a pessoa jurídica"319 . Para o autor, não há dificuldade insuperável para o alcance dessa adaptação dogmática. Em verdade, é possível renunciar à capacidade de ação e de culpabilidade, se se tiver em conta o fim da medida estatal e este estiver embasado sobre um princípio legitimador que fundamente essa responsabilização de forma suficiente tendo em conta aspectos de justiça ${ }^{320}$.

Além dessa percepção, SCHÜNEMANN parte do pressuposto de que é impossível aplicar o princípio da culpabilidade, em sua concepção tradicional, à pessoa jurídica, devendo-se buscar, então, outra forma de legitimação, que para ele deve se apoiar no “estado de necessidade do bem jurídico".

A construção do estado de necessidade do bem jurídico, partindo do pressuposto da incompatibilidade entre o instituto da culpabilidade e o ente coletivo, tenta justificar a imposição de pena recorrendo a critérios preventivos ${ }^{321}$. O paralelo com o estado de necessidade advém do fato de se reconhecer a debilidade da eficiência preventiva no âmbito da criminalidade de empresa ${ }^{322}$, reconhecendo-se, portanto, que para a aplicação da pena à pessoa jurídica é necessário apurar a existência de uma verdadeira situação de necessidade, no sentido da presença de uma ameaça ao bem jurídico na qual as medidas jurídicas existentes se demonstrarm insuficientes e em que há dificuldade de se identificar o autor individual concreto.

59.

${ }^{319}$ SCÜNEMANN, Bernd. Unternehmenskriminalität und Strafrecht - Eine Untersuchung der Verantwortlichkeit der Unternehmen und ihrer Führunfskräften nach geltendem und geplanten Straf - und Ordnungwidrigkeitenrecht. Koln/Berlin/Bonn/München, 1979, p. 233. apud BACIGALUPO, Silvina. La responsabilidad..., p. 161.

${ }^{320}$ Sobre isso, ver BACIGALUPO, Silvina. La responsabilidad..., p. 162.

${ }^{321}$ Segundo PERCY GARCía CAVERO, alguns autores, para evitar evidentes contradições, “[...] recurren a la salida dogmática de reconhecer cierta capacidad de imputación jurídico-penal de la persona jurídica, pero fundamentan la imposición de la pena en criterios preventivos ajenos al principio de culpabilidad (como el estado de necessidade preventivo de bienes jurídicos de Schünemann.”. GARCÍA CAVERO, Percy. La persona..., p. 73.

${ }^{322}$ SCHÜNEMANN, Bernd. Unternehmenskriminalität und Strafrecht, p. 234. apud BACIGALUPO, Silvina. La responsabilidad..., p. 162. 
Mas no discurso de legitimação da sanção penal não basta este raciocínio de necessidade, muito afeto, é bem verdade, aos próprios argumentos político-criminais para a admissão da responsabilidade penal da pessoa jurídica. A legitimação da pena que se busca deve ir além. Deve-se indagar, ademais, a idoneidade da medida a ser aplicada. Em outras palavras - e talvez melhor esclarecendo - deve-se perquirir se a sanção aplicada é apta "para fortalecer a eficiência de prevenção no âmbito do Direito Penal econômico" "323, no sentido de uma prevenção especial, reafirmando o controle interno da empresa ${ }^{324}$, derivando, ao que se pensa, como quase todo o discurso da responsabilidade do ente coletivo, para a busca de uma "autorregulação".

Ademais, é necessário atentar para a proporcionalidade da sanção, ponderandoa em face da afetação de outros valores do ordenamento jurídico. Nesse sentido, oportuno salientar que para SCHÜNEMANN o argumento de que os membros da empresa serão afetados pela sanção sem que tenham sua própria culpabilidade é inservível para afastar a proporcionalidade da medida, uma vez que é próprio do risco empresarial o suportar não apenas benefícios, mas também desvantagens ${ }^{325}$.

A construção de SCHÜNEMANN, com tais critérios para a aplicação da sanção penal da pessoa jurídica, parece apresentar, ao que se pensa, uma dificuldade fundamental. É que, sempre que seja possível apurar o autor físico do delito, haverá problemas para se dirigir ao ente coletivo uma sanção, na medida em que o caráter de necessidade da pena à empresa, tal como por ele construído, parece desaparecer. Bem por isso, ScHÜNEMANN reviu seu pensamento para admitir a configuração do estado de necessidade mesmo quando identificado e sancionado um autor individual. Nesses casos, reconhece que a sanção ao ente coletivo se justifica porque houve a produção de uma vantagem para a empresa e esta não produziu medidas de cuidado suficientes para evitar a prática delitiva em seu bojo. Esse raciocínio se converte em critérios para a aplicação da sanção penal à pessoa jurídica.

É importante observar que, para SCHÜNEMANN, essa base de legitimação por ele desenvolvida, e que se apresenta como um substitutivo da culpabilidade (para ele, impossível de ser afastadas de sua concepção tradicionalmente vinculada à pessoa física), deve ser empregada para possibilitar a aplicação de qualquer sanção, penal ou administrativa $^{326}$. É perceptível, portanto, que não se pode fugir da busca de um critério de

\footnotetext{
${ }^{323}$ BACIGALUPO, Silvina. La responsabilidad..., p. 163.

${ }^{324}$ Id. Ibid., p. 163.

${ }^{325}$ Id. Ibid, p. 163.

${ }^{326}$ Id. Ibid, p. 162.
} 
legitimação tendo por argumento a aplicação de medidas sancionatórias não penais ${ }^{327}$. De qualquer modo, critica-se a solução adotada pelo autor na medida em que, excluir a culpabilidade como pressuposto da pena acabaria por afrontar a estrutura não só do sistema jurídico-penal, como também do Direito Administrativo Sancionador, para aqueles que defendem uma responsabilização administrativa.

\subsubsection{A culpabilidade pela consciência especial da pessoa jurídica de HAFTER}

HAFTER é apontado como um dos primeiros autores a se ocupar da formulação de um conceito de culpabilidade para a pessoa jurídica ${ }^{328}$. Reconhece, em sua formulação, a existência de uma vontade especial da pessoa jurídica, que não se confunde com a dos indivíduos que a compõem, e que se configura com o acordo conjunto de seus membros ou pela decisão de um órgão competente. Aliás, é nessa ideia que funda a consciência especial da pessoa jurídica, consciência esta que permite qualificar a atuação e a vontade do ente coletivo como culpável ${ }^{329}$. Assim, a atuação ou a vontade da pessoa jurídica só serão culpáveis quando emanados dessa decisão conjunta ou dos órgãos competentes, nunca das vontades individuais de seus componentes.

Perceba, contudo, que a formação da vontade (de que se falou até agora), não pode, para HAFTER, se confundir com a execução da vontade. Em outras palavras - e talvez melhor esclarecendo - enquanto a primeira só pode advir do já mencionado acordo conjunto ou dos órgãos competentes, a segunda pode se dar pela atuação conjunta ou de indivíduos singulares concretos, inclusive daqueles que não compõem a estrutura da pessoa

\footnotetext{
${ }^{327}$ Aliás, há quem defenda que, mesmo no âmbito das medidas de segurança, a justificação de sua imposição à pessoa jurídica é diferenciada em relação à pessoa física. Neste sentido, STRATENWERTH, tal como SCHÜNEMANN, legitima a aplicação da sanção ( medida de segurança) com o interesse público, fazendo uso não da prevenção especial, tal como nas medidas de segurança aplicáveis às pessoas físicas, mas da prevenção geral como critério. Sobre isso, ver: BACIGALUPO, Silvina. La responsabilidad..., p. 165-168. Percebe-se, portanto, que mesmo àqueles que viam a incompatibilidade da pessoa jurídica com o sistema de aplicação de penas, reconhecem sua posição peculiar como sujeito e a necessidade de se indagar sobre fundamentos próprios para a imposição, no caso, de medidas de segurança. Ou seja, negar-se a aplicação de pena à pessoa jurídica não permite escapar da necessidade de se buscar um "novo fundamento" para a responsabilização desse sujeito.

${ }^{328}$ Assim afirma GÓMEZ-JARA DíEZ: "Una de las primera formulaciones de la culpabilidad de la persona jurídica la ofreció Hafter a princípios del siglo XX." citando HAFTER, Ernst. Die Delikts-und Straffähigkeit der Personenverbänden. Berlin: Springer, 1903, p. 94 e ss. apud GÓMEZ-JARA DÍEZ, Carlos. La culpabilidad de la persona jurídica. In: BAJO FERNÁNDEZ, Miguel; FEIJOO SÁNCHEZ, Bernardo José; GÓMEZ-JARA DÍEZ, Carlos. Tratado de responsabilidad penal de las personas jurídicas. Navarra: Aranzandi, 2012, p. 155-156.

${ }^{329}$ Id. Ibid., p. 156.
} 
jurídica $^{330}$.

Um interessante aspecto ressaltado por HAFTER é que, para que a atuação ou vontade do ente coletivo seja tida como culpável é necessária a presença de uma qualificação especial neste "agir" ou "querer". Dito de outro modo, exige-se uma consciência especial da pessoa jurídica, que deriva justamente da decisão do órgão ou do acordo conjunto $^{331}$.

Pensa-se, contudo, que tal definição dessa consciência especial não alcança um esclarecimento desejável. Afinal, a consciência será qualificada como "especial" justamente por derivar formalmente de certo "sujeito", por assim dizer (a decisão do órgão ou o acordo conjunto), sem que tenha um conteúdo próprio que lhe caracterize.

\subsubsection{A culpabilidade pelo espírito normativo da pessoa jurídica de BUSCH}

A interessante construção de BuSCH parte da ideia da existência de um espírito normativo da pessoa jurídica que se expressa na ação delitiva. Esse espírito se produz por todos os membros da pessoa jurídica, que constroem uma certa moral na comunidade organizada, permitindo que a atividade do ente coletivo acabe possuindo um caráter delitivo.

É evidente que tal construção acaba por definir que todos os indivíduos componentes da pessoa jurídica têm um dever de atuar de forma a evitar a formação desse espírito normativo contrário ao direito ${ }^{332}$, acabando por se fundar numa suposição de infração de deveres por todos os componentes do ente coletivo, acabando por incorrer numa inadmissível "culpabilidade suposta com base na participaçao econômica na associação" ${ }^{333}$. Parece, portanto, uma construção que, de certa maneira, responde às objeções levantadas à responsabilidade penal da pessoa jurídica relacionadas aos efeitos da pena sobre indivíduos componentes do ente colectivo que não concorreram de qualquer modo para a produção do comportamento delitivo, na medida em que, sob tal ótica, todos

\footnotetext{
${ }^{330}$ Id. Ibid., p. 156.

${ }^{331}$ Id. Ibid., p. 156.

${ }^{332}$ Como constata GÓMEZ-JARA DíEZ: “Así, Busch considera que, en realidad, no existen inocentes en la persona jurídica; todos han participado en la creación de esa atmosfera o espíritu. El pensamento que late en el fondo es que la participación en una persona jurídica fundamenta el deber para el individuo concreto de actuar - en lo que él se refiere y en la medida de sus possibilidades - de tal manera que la actividad dedicada al cumplimiento de los fines de la persona jurídica no adopte un carácter lesivo socialmente.”. Id. Ibid., p. 157.

${ }^{333}$ Cf. PASTOR MUÑOZ, Nuria. ¿Organizaciones culpables? Recensión a Carlos Gómez-Jara, La culpabilidad penal de la empresa. InDret. Barcelona: 2006, p. 5. Disponível em: <http://www.indret.com/pdf/340.pdf>. Acesso em: 17 maio 2012.
} 
que integram a estrutura empresarial contribuiriam com o crime, ainda que por sua ação omissiva de não atuar de forma a criar um espírito normativo na empresa favorável ao direito. Contudo, salta aos olhos em tal formulação a definição de um dever abstrato negativo para todos os componentes da pessoa jurídica, de não produzir um espírito normativo contrário ao direito.

\subsubsection{A culpabilidade pela organização própria de TIEDEMANN}

\section{A construção de TIEDEMANN surgiu como interpretação do $§ 30$ da OWiG} (Ordnungswidrigkeitengesestz - Lei alemã de contravenções administrativas), que, alterada em 1986, trouxe a previsão de sanção (no caso, multa) às empresas, sem a qualificação de consequência acessória. ${ }^{334}$ Diante da discussão sobre a natureza jurídica de tais sanções aos entes coletivos, TIEDEMANN encontrou espaço para a reelaboração do conceito de culpabilidade das pessoas jurídicas ${ }^{335}$. Constatando que as exigências de culpabilidade no âmbito das infrações administrativas são menos rigorosas, recorre a categorias sociais e jurídicas para fundamentar sua culpabilidade, fugindo, portanto, da reprovação ética ${ }^{336}$.

\footnotetext{
${ }^{334}$ Sobre isso, ver: BAJO FERNÁNDEZ, Miguel. BACIGALUPO, Silvina. Derecho penal..., p. 128. Para ZUÑIGA RODRíGUEZ, contudo, a teoria da organização defeituosa da empresa como fundamento de sua responsabilidade própria foi desenvolvida por Tiedemann a partir da análise das construções da União Européia para as infrações contra a livre concorrência e o Direito anglo-saxão. ZUÑIGA RODRÍGUEZ, Laura. Bases para un..., p. 238. O certo é que, tanto na OWiG, como no Direito comunitário relacionado à matería de livre concorrência, há a previsão de imposição de multa administrativo-penal, como o próprio TIEDEMANN constatou: "Este concepto de pós-guerra fue elaborado de manera sistemática por el legislador alemán en la ley sobre las llamadas contravenciones al orden (Ordnungswidrigkeiten), en cuyo art. 30 se prevê la imposición de una multa administrativo-penal (Geldbusse) a las agrupaciones, [...]. Esta multa, que lleva un nombre diferente a la multa criminal (Geldstrafe), persigue unos fines a la vez preventivos y retributivos sin que, por consiguiente, suponha un reproche ético o moral. Podemos caracterizar de la misma forma las multas impuestas a las empresas en el Derecho comunitário (sobre todo en matéria de la libre competendia y de tráfico) [...].” TIEDEMANN, Klaus. Nuevas tendências..., p. 407.

${ }^{335}$ Não se pode descurar, é certo, que antes da discussão sobre a culpabilidade, TIEDEMANN também reconheceu a capacidade de ação da pessoa jurídica, constatada pela existência de uma norma de imputação dirigida a este ente coletivo. Contudo, o obstáculo principal residia noa aceitação de uma capacidade de culpabilidade. Esta é a constatação feita por BAJO e BACIGALUPO: "El hecho de que el $\S 30$ OWiG prevea la aplicación directa a la persona jurídica (con ciretos requisitos) de una multa, puso de manifiesto que las asociaciones mencionadas en el $\S 30 \mathrm{OWiG}$ son las detinatarias de la norma. [...] Es decir, la existência de una norma de imputación permite aceptar la exisencia de una acción de la persona jurídica, aunque ésta tenga que ser realizada en efecto por un órgano (u outra persona) en nombre de la misma, es decir, aunque se trate de la imputación de una acción ajena. De esta manera Tiedemann acepta la capacidad de acción de la persona jurídica, pero aún es necesario salvar el obstáculo principal para la imputación de un delito: la capacidad de culpabilidad.”. Id. Ibid., p. 129.

${ }^{336}$ Neste sentido, afirma GÓMEZ-JARA DíEZ: "Mediante una argumentación cuyo atractivo dificilmente puede negarse, TIEDEMANN intenta salvar los obstáculos que tradicionalmente se presentan a la posibilidad de afirmar una culpabilidad empresarial, indicando que la culpabilidad en el ámbito de las contravenciones del ordem presenta unas exigências menores que la culpabilidad en el ámbito jurídico-penal. Por ello, puede estimarse correcto que las consideraciones - por lo menos iniciales - de TIEDEMANN van referidas única y exclusivamente a una culpabildad que no es intrínsecamente jurídico-penal. En efecto, en lugar de la
} 
Dessa maneira desenvolve seu conceito de "culpabilidade por defeito de organização", o qual tem como núcleo a ideia de uma deficiência organizativa na empresa abrindo espaço à prática delitiva, o que pode ser traduzido, portanto, no desenvolvimento de uma posição de garante do ente coletivo, na medida em que deve se organizar de forma a evitar o cometimento de crimes em seu bojo, para que não se veja responsabilizado por isso.

Para tanto, utiliza-se da estrutura do "fato de conexão", constatando que um fato realizado pelos indivíduos que compõem a estrutura empresarial (o fato de conexão) será considerado como fato da própria pessoa jurídica se produzido como consequência da deficiência organizativa ${ }^{337}$.

Por sem dúvida, sua construção revela uma especial contribuição por reorientar o conceito de culpabilidade, remetendo-o a referências jurídicas e sociais. Contudo, não parece que o conceito de TIEDEMANN seja completamente avesso a conteúdos éticos ou morais que possam ser exigidos para a responsabilização penal. Isto porque, o próprio autor, reconhecendo que em muitas jurisdições ainda se entende a culpabilidade no Direito Penal como reprovação moral, salienta que não há impossibilidade de se reconhecer as pessoas jurídicas como destinatárias de normas jurídicas dotadas de caráter ético e, portanto, como entes capazes de violar tais normas. Dessa maneira, deve-se entender que o dever das empresas de se organizarem corretamente é um dever próprio, não das pessoas que a compõem, havendo na linguagem da sociedade o reconhecimento da culpabilidade da própria empresa por tais deveres, reconhecimento esse que não está isento de valorações éticas e morais ${ }^{338}$.

culpabilidad en el sentido dogmático tradicional introduce un concepto de culpabilidad en sentido amplio,el cual pudiera catalogarse más bien como una responsabilidade orientada fuertemente hacia referencias jurídicas.”. GÓMEZ-JARA DÍEZ, Carlos. La culpabilidad penal..., p. 151. No mesmo sentido, ver: BAJO FERNÁNDEZ, Miguel. BACIGALUPO, Silvina. Derecho..., p. 129.

${ }^{337}$ Ver: BAJO FERNÁNDEZ, Miguel. Bacigalupo, Silvina. Derecho penal..., p. 130. GÓMEZ-JARA DÍEZ, Carlos. La culpabilidad penal..., p. 151-152.

${ }^{338}$ Afirma o autor: "Ciertamente, muchas de las jurisdicciones continúan entendendo la culpabilidad en Derecho Penal como un reproche moral, pretendendo que tal reproche no podría hacerse respecto de las personas jurídicas. Según esta opinión clásica, la responsabilidade penal en el sentido de "respuesta" negativa a las normas jurídicas no podría ser dada más que por individuos que por si solos podrían abusar de su libertad de pronunciarse a favor o contra del Derecho. No obstante, nada impede considerar a las personas jurídicas como destinatarias de normas jurídicas revestidas de un caráter ético, al igual que como ente en condiciones de violar estas normas. Por ello debería ser deber de la propia persona jurídica el organizarse correctamente, y no, como pretende SCHÜNEMANN, debería recaer este deber en las personas físicas. De esto puede derivarse el concepto de culpabilidad propia de la persona jurídica. ¿Tenemos acaso que renunciar a un reproche moral contra las personas jurídicas? ¡Pero si en la realidad de la vida social hablamos de la culpabilidad de la empresa que há contaminado un río (ejemplo expuesto por el finalista Hirsch) o que há obtenido subvenciones fraudulentamente! En la vida y en la lenguage de la sociedade, una culpabilidad de la empresa se encuentra completamente reconocida, y esta culpabilidad no está totalmente exenta de la huella ética o moral, aun cuando la coloración moral tome un contenido particularmente diverso.”. TIEDEMANN, Klaus, Nuevas tendencias... , p. 414. 
Em sua construção teórica, TIEDEMANN recorre a duas categorias do Direito Penal como fundamentação dogmática: a omissão e a "actio libera in causa". Numa síntese, constata que a responsabilidade da pessoa jurídica se dá pela omissão, o que facilitaria a imputação da ação ou omissão das pessoas físicas componentes da estrutura empresarial a este ente coletivo, tendo-se em conta que a responsabilidade pela omissão é juridicamente relevante no âmbito de uma imputação socionormativa, mais fácil de ser compatibilizada com a realidade da pessoa jurídica. Já a aplicação do conceito de "actio libera in causa" pretende superar o problema da ausência de culpabilidade na relação direta do órgão ou representante com a prática delitiva, consignando que a ausência de culpabilidade nesse momento não influenciará a responsabilização penal da empresa, já que a conduta delituosa da pessoa física foi, em verdade, causada pela culpabilidade empresarial, que lhe é antecedente ${ }^{339}$.

A opção pela utilização dessas duas categorias do direito penal é objeto de críticas doutrinárias por estarem ligadas a uma responsabilidade pelo fato alheio, retomando, em certa medida, os problemas atinentes à mera trasladação dos elementos do direito penal da pessoa física à pessoa jurídica, semelhante ao esquema da imputação de um fato de terceiro ${ }^{340}$. Afirma-se que em sua teoria resta indefinido se a culpabilidade organizativa seria uma culpabilidade própria da empresa ou uma culpabilidade dos órgãos e representantes que restou imputada ao ente coletivo, pois não se esclarece do que derivaria o conteúdo dessa responsabilidade pela deficiência de organização ${ }^{341}$. E, mesmo que se entenda que a culpabilidade organizativa seja uma culpabilidade própria da empresa, permanece indefinido o que consistiria essa culpabilidade ${ }^{342}$.

\footnotetext{
${ }^{339}$ Como bem esclarece GóMEZ-JARA DíEZ, a utilização destes dois conceitos do Direito Penal servem como ponto de apoio para que Tiedemann possa superar o problema da responsabilidade por fato alheio. Afirma aquele autor: "Quizá no resulte exagerado señalar que, en cuanto se toma como parte del fundamento de la responsabilidad la existência de unos hechos de conexión - sc. un determinado hecho de la persona física se "conecta" con la persona jurídica -, inmediatamente se plantea la problemática de ello y, por conseguiente, recurre a diversas categorias del Derecho penal donde se fundamenta este tipo de responsabilidade. Por un lado, y éste parece ser el topos que más se corresponde con su fundamento de la imputación, alude a la omisión. [...] Por otro lado, también alude que el fundamento de la imputación por él señalado se encuentra en una construcción bien conocida en el Derecho penal tradicional: la actio libera in causa.”. GÓMEZ-JARA DÍEZ, Carlos. La culpabilidad penal..., p. 152.

${ }^{340}$ Nesse sentido: SCHÜNEMANN, Bernd. Ist eine direkte Haftung von Wirtschaftsunternehmen zulässig und erforderlich?, In: International Conference on Environmental Law, p. 433 e ss. e 459. apud SILVA SÁNCHEZ, Jesús-María. Normas..., p. 85.

${ }^{341}$ Afirma SILVA SÁNCHEZ que: "resulta más que dudoso si la culpabilidad por defecto de organización es expresión de una culpabilidad en sentido estricto de la persona jurídica o, por el contrario, una regla de transferência de responsabilidade a la persona jurídica por el hecho culpable de las personas físicas que, en el seno de la misma, infringen los deberes de organización y vigilância que recaem sobre ellos.”. Id. Ibid., p. 85. ${ }^{342}$ Interessante a crítica empreendida por LAMPE, para quem o conceito de TIEDEMANN, além de vago, por não esclarecer se se refere à culpabilidade pessoa ou da pessoa jurídica, não define o que consiste a
} 
De outra banda, não se pode olvidar as críticas empreendidas especificamente em relação aos institutos do Direito Penal utilizados nessa construção. Com relação à actio libera in causa, diz-se que sua aplicação em relação à responsabilidade penal da pessoa jurídica apenas possibilita a transferência do momento de apuração da culpabilidade, sem superar, contudo, a necessidade de uma decisão voluntária ou livre, bem como a previsibilidade, como requisitos de tal figura. Assim, a utilização desse conceito não supera a ausência de fundamento material da culpabilidade ${ }^{343}$, retomando, em verdade, a aplicação de uma culpabilidade de terceiros, na medida em que a actio libera in causa remete à decisão prévia do mesmo autor e, na sua trasladação para a pessoa jurídica, a infração prévia seria derivada da ação de terceiros, e não do próprio ente coletivo ${ }^{344}$. Já no que concerne à omissão, ressalta-se que, ainda que seja possível embasar a posição de garante da pessoa jurídica, os argumentos para tanto acabam se cingindo a uma análise restrita ao tipo objetivo, não resolvendo, portanto, a questão relativa à ausência de elementos subjetivos a justificar a imposição de pena, como a capacidade de evitação ${ }^{345}$.

Salienta-se, também, uma insuficiência de conteúdo em sua construção por albergar apenas a deficiência organizativa, descurando que uma filosofia empresarial criminógena também consistiria em fator de responsabilidade do ente coletivo por permitir, ou, mais ainda, incentivar práticas delitivas no bojo empresarial ${ }^{346}$. Fala-se, ademais, que a

culpabilidade empresarial, na medida em que falar de infração de deveres se traduziria num injusto da organização. Nas palavras do autor: "Más importante resulta una vaguedad: ¿se está refiriendo a la culpabilidad personal de los "órganos o representantes", esto es, la culpabilidad del dirigente de una sociedad limitada, o a la culpabilidad de la propia empresa? Si se está refiriendo a la culpabilidad personal, sigue quedando por resolver la cuestión, como ocurría anteriormente, de por qué pde serle imputada a la persoan jurídica y conducir a su punición. La respuesta me parece algo difícil, puesto que ya en Derecho civil una persona puede responder por la culpabilidad de otro, pero no puede ser culpada por la culpabilida de otra. [...] $\mathrm{Si}$, por el contrario, bajo el término "culpabilidad organizativa" Tiedemann entende una culpabilidad propia de la empresa, sigue aberta la cuestión sobre su causa de origen. En verdade, Tiedeann puede remitirse a una infracción de deberes que afectan a la empresa como tal; con outra palavras a un "injusto de la organización. Sin embargo, sigue quedando poco claro en qué consiste la "culpabilidad" de la empresa.". LAMPE, ErrnstJoachim. La dogmática..., p. 157-158.

${ }^{343}$ Sobre isso, ver: FEIJÓO SÁNCHEZ, Bernardo. Sanciones..., p. 77-78.

${ }^{344}$ Bem esclarece GÓMEZ-JARA DÍEZ: "En primer lugar, se ha criticado especialmente el recurso a la actio libera in causa. Esta crítica tiene dos vertientes, si bien ambas se encuentran estrechamente relacionadas. La primera vertiente, en realidade, se fundamenta en la incapacidad de acción de la persona jurídica. Se entiende que, independentemente del modelo de la a.l.i.c. que se utilice, siempre se acaba en el mismo punto de partida, cual es la decisión libre del autor materializada en una acción. Dado que dicha decisón/acción no puede ser adoptada/realizada por la empresa como tal, no existe una identidad estructural entre empresa e individuo en lo que a la a.l.i.c. se refiere, La segunda vertiente senãla que, para salvar esa incapacidad de acción, no se pude recurrir a un tercero: la a.l.i.c. siempre se refiere a la decisión/acción previa del mismo autor, no de un terceiro. Con ello se está haciendo expressa referencia a la infracción previa de los órganos de vigilancia ( $\$ 130 \mathrm{OWiG}$ ): en esse caso se tomaría como parâmetro de referencia, de nuevo, la culpabilidade de un tercero.”. GÓMEZ-JARA DÍEZ, Carlos. La culpabilidad penal..., p. 157.

${ }^{345}$ Id. Ibid., p. 78.

${ }^{346}$ Afirma LAMPE: “[...] la comisión de delitos no sólo puede ser motivada o beneficiada por una carência 
exigência de um "fato de conexão" acaba por tornar insolúvel o problema da irresponsabilidade organizada (questão chave na admissão da responsabilidade penal da pessoa jurídica), uma vez que, nos casos em que não se pode apurar os autores concretos (aliás, os casos mais sintomáticos do Direito Penal empresarial e que fizeram retomar a necessidade de responsabilização do ente coletivo), não se poderá apurar o "fato de conexão", restando prejudicada a responsabilidade criminal da empresa ${ }^{347}$.

As críticas mais veementes, contudo, dirigem-se ao fato de que o defeito de organização não traduziria uma "culpabilidade", mas sim consistiria em um dado objetivo $^{348}$, equiparando, portanto, culpabilidade e tipo objetivo. Essa crítica, aliás, muito se apoia no fato de que, havendo a infração objetiva de norma de organização empresarial, se operaria um presunção iuris et de iure contra a empresa, inexistindo forma de eximir sua responsabilidade $^{349}$. Para autores como FEIJóo SÁNCHEZ, aliás, esse problema estaria ligado à própria origem da responsabilidade por defeito de organização, posto que criada como fundamento para infrações administrativas do Direito alemão, e não para justificar uma imputação jurídico-penal, revelando, portanto, uma racionalidade própria “das sanções administrativas e dos sistemas de organização e controle da Administração", apoiada na lógica utilitarista de custos e benefícios ${ }^{350}$. Uma outra leitura, contudo, enxerga

organizativa, sino también por carências en la "filosofia" de la empresa, cuando el centro de la misma es, por ejemplo, la maximización de benefícios a costa del entorno social o ecológico. En este sentido la pregunta sobre la responsabilidade no puede contestarse haciendo referencia a una "culpabilidad organizativa". LAMPE, Ernst-Joachim. op. cit., p. 158.

${ }^{347}$ Consigna GÓMEZ-JARA DíEZ: “[...] si se exige la presencia de un hecho de conexión sigue sin solucionarse el problema de la "irresponsabilidad organizada". En definitiva, los casos más problemáticos del Derecho penal empresarial son aquellos en los que no puede identificar-se un autor concreto que haya llevado a cabo una acción, por lo que en estos casos faltará e necessário hecho de conexión y, en consecuencia, no se generará la responsabilidad de la empresa. “. GÓMEZ-JARA DÍEZ, Carlos. La culpabilidad penal..., p. 158.

${ }^{348}$ Assim afirma SILVA SÁNCHEZ: "[...] del defecto de organización no se pude derivar, en sí, una "culpabilidad": el defecto de organización sería, más bien, un "dato objetivo", quedando pendiente de aclaración la cuestión de en qué casos y por qué la persona jurídica puede ser estimada "culpable" del defecto de organización que se produce en su seno". SILVA SÁNCHEZ, Jesús-María. Normas..., p. 85.

${ }^{349}$ Consigna GÓMEZ-JARA DíEZ: “[...] Tiedemann entiende que la empresa no puede librarse de la sanción mediante la prueba de una organización suficiente, ni que tampoco debe probarse que el hecho de conexión deve reconducirse causalmente al déficit organizatico. Su concepto de culpabilidad organizativa empresarial constituye un princípio de responsabilidade (Haftungsprinzip) que sirve de fundamento al $\S 30 \mathrm{OWiG}$ en sentido análogo al $\$ 31$ del Código Civil alemán. Se trata, ni más ni menos, de un caso de responsabilidad objetiva y, pese a que Tiedemann intenta desmarcarse de esa consecuencia lógica indicando que el concepto de culpabilidad organizativa "no es materialmente idêntico al correpondiente concepto del Derecho civil", lo certo es que negar la posibilidad de exculpación reviste los caracteres típicos de una pura responsabilidad objetiva; Será precisamente este presunción iuris et de iure la que más crítica reciba por parte de la doctrina especializada.”. GÓMEZ-JARA DÍEZ. Carlos. La culpabilidad penal..., p. 153-154.

${ }^{350}$ Afirma o mencionado autor: "[...] la responsabilidad por organización o por defecto de organización pensada en princípio para fundamentar ciertas infracciones administrativas del Derecho alemán pero no para crear un auténtico sistema de imputación jurídico-penal - no exime de responsabilidade siempre que haya infracción objetiva de normas administrativas o penales. La organización correcta (falta de culpabilidad) no exime de responsabilidade careciendo de efectos disculpantes. La supuesta "culpabilidad por organización" 
nessa "responsabilidade objetiva" a preocupação de que apenas o cumprimento de normas organizativas básicas seja utilizado como causa de exculpação, retirando a eficácia prática dessa modalidade de responsabilização. Assim, o defeito não estaria na origem dessa concepção teórica de culpabilidade, mas na inadmissão de causas de exculpação ${ }^{351}$.

Ainda que presentes tais críticas, é inegável que a construção de TIEDEMANN revelou grande contribuição para o desenvolvimento do conteúdo material da culpabilidade, tendo influenciado as construções posteriores ao reconhecer que a responsabilidade penal empresarial estaria fundada na necessidade de se organizar corretamente. É bem verdade que sua concepção teórica não almejou um conceito de culpabilidade organizativa no Direito Penal, mas seus argumentos abriram caminho para se dar um passo além, vislumbrando um sentido normativo e ético-social para a culpabilidade (e não psicológico e ético-individual), que permitiria falar de uma culpabilidade do ente coletivo $^{352}$.

Reconhece, também, a possibilidade de utilização de modelos empresariais no Direito Penal empresarial como parâmetros gerais de valoração, assim como ocorre no Direito Penal tradicional ${ }^{353}$, devendo-se, portanto, avaliar empresas equivalentes no porte, estrutura etc.

Outro ponto de extrema relevância teórica da concepção desse autor foi atentar para a dimensão temporal da culpabilidade empresarial, que, diversamente da culpabilidade individual, remete a um momento antecedente, revelando, portanto, uma

no es tal. Se equipara culpabilidad con tipo objetivo ya que la realización de los elementos objetivos del tipo por parte de algún miembro de la empresa opera iuris et de iure contra la persona jurídica (responsabilidad objetiva). Una estratégia como esta que pretende determinar o motivar a las empresas con base en un cálculo económico o utilitarista entre costes (de la sanción) y benefícios (de la organización defectuosa) es propia de las sanciones administrativas y de los sistemas de organizacion y control de la Administración (autotutela ejecutiva de la Administración).”. FEIJÓO SÁNCHEZ, Bernardo. Sanciones..., p. 69-71.

${ }^{351}$ Neste sentido, afirma GóMEZ-JARA DíEZ: [...] se ha criticado la inadmisión de causas de exculpación en este ámbito. Un concepto de culpabilidad coherente debe admitir causas de exculpación; si no lo hacem en realidade se trata de supuestos de responsabilidad objetiva. En efecto, si el principal logro alcanzado por este planteamiento consiste en haber procedido a la diferenciación de una culpabilidad especificamente empresarial, no puede, a reglón seguido, intentar evitar las consecuencias que se derivan de dicha diferenciación. O se imputa una culpabilidad empresarial - autorresponsabilidad - o se imputa la de otra persona - heterorresponsabilidad -; pero lo que no se puede hacer es mezclar fundamentos de un modelo con consecuencia de outro. La preocupación que se deja entrever en la argumentación de estos autores es el miedo a que la empresa pudiera exculparse continuamente mediante un cumplimiento superficial de las norma básicas de organización empresarial.”. GÓMEZ-JARA DÍEZ, Carlos. La culpabilidad de..., p. 159. Uma tentativa de correção dessa deficiência teórica foi dada por BRENDER, que identificou como causa de exculpação imprópria a exclusão do fato de conexão (demonstração de que este não foi produzido). BRENDER, Markus. Die Neuregelung der Verbandstäterschaft im Ordnungwidrigkeitenrecht, p. 116. apud GÓMEZ-JARA DÍEZ, Carlos. La culpabilidad penal..., p. 156. Contudo, GóMEZ-JARA DíEZ critica esta solução, observando que se trata mais uma vez de culpabilidade individual. Id. Ibid., p. 156.

${ }^{352}$ Id. Ibid., p. 160.

${ }^{353}$ Id. Ibid., p. 160-161. 
culpabilidade diferenciada. Essa dimensão temporal "sui generis" da culpabilidade empresarial encontrará expressão em algumas soluções teóricas posteriores, como a "culpabilidade pelo caráter empresarial" de LAMPE e a "culpabilidade pela condução empresarial" de HEINE ${ }^{354}$.

\subsubsection{A culpabilidade funcional do órgão de SCHROTH}

As influências das reflexões de TIEDEMANN sobre os autores que lhe seguiram pode ser constatada na construção de HANS-JÜRGEN SCHROTH. Seu conceito mostra a influência da concepção normativa e social de culpabilidade.

Partindo do reconhecimento de que a empresa tem capacidade de ação derivada dos seus componentes, entendida como a capacidade de imputar como própria as ações daqueles indivíduos que compõem a sua estrutura ou que estejam autorizados para por ela atuar, capacidade essa identificada como equivalente à capacidade de ação natural do indivíduo $^{355}$, o autor reconhece que o ente coletivo pode se desviar dos deveres de comportamento que lhe são impostos, deveres esses que partem da construção de um modelo padronizado de empresa: a "empresa média" 356 . Trabalha, assim, com um conceito paralelo ao do Direito Penal tradicional, qual seja, o de "homem médio".

A culpabilidade que se apura na empresa é uma culpabilidade funcional, que não se confundiria, segundo o autor, com a mera imputação da culpabilidade dos órgãos componentes da estrutura empresarial ${ }^{357}$. Imputa-se à empresa um comportamento culpável que se expressa na culpabilidade empresarial, na medida em que a expressão comportamental do órgão é resultado do agrupamento organizativo das condutas humanas na empresa. Assim, o comportamento do órgão que se expresse de forma contrária ao direito nada mais é do que o resultado de uma "vontade coletiva defeituosa" de uma “decisão coletiva pelo injusto",358, ou seja, da culpabilidade empresarial ${ }^{359}$, que não se confunde, para o autor, com a culpabilidade individual de cada membro do órgão, as quais são totalmente independentes. O comportamento do órgão expressa a soma dos

\footnotetext{
${ }^{354}$ Id. Ibid., p. 158.

${ }^{355}$ Sobre isso, ver: LAMPE, Ernst-Joachim. La dogmática jurídico-penal..., p. 158.

${ }^{356}$ SCHROTH, Hans-Jürgen. Unternehmen als Normadressaten und sankitionssubjekte: eine Studie zum Unternehmensstrafrecht, p. 200. apud GÓMEZ-JARA DÍEZ, Carlos. La culpabilidad penal..., p. 162.

${ }^{357}$ SCHROTH, Hans-Jürgen. Unternehmen als ..., p. 204. apud GÓMEZ-JARA DÍEZ, Carlos. La culpabilidad penal..., p. 162.

${ }^{358}$ SCHROTH, Hans-Jürgen. Unternehmen als ..., p. 198. apud GÓMEZ-JARA DÍEZ, Carlos. La culpabilidad penal..., p. 163.

${ }^{359}$ GÓMEZ-JARA DÍEZ, Carlos. La culpabilidad penal..., p. 162.
} 
comportamentos humanos organizativamente agrupados na empresa ${ }^{360}$. Crê, assim, que tal formulação permite sair do campo da responsabilidade por fato alheio.

Critica-se a concepção de SCHROTH por embasar-se em argumentos circulares $^{361}$, fundamentando a culpabilidade empresarial com a imputação da culpabilidade à empresa, demonstrando uma legitimação positivista de seus argumentos, no sentido de que tal construção é admissível porque o legislador assim o quis ${ }^{362}$. Diz-se, ainda, que sua formulação teórica não esclarece a relação entre a culpabilidade individual e a empresarial, acabando por não superar um modelo de responsabilidade por fato de terceiro, tornando dependente a responsabilização penal da empresa da apuração de alguma decisão do órgão ${ }^{363}$, incorrendo nos mesmos problemas apontados com relação à construção de TIEDEMANN.

Contudo, o que nos parece importante na formulação de SCHROTH é a percepção de um conceito de "empresa média". Para CARLOS GóMEZ-JARA DíEZ, a importância desse conceito reside no fato de demonstrar a existência de expectativas sociais e jurídicas sobre a empresa, ainda que SCHROTH não identifique como tais expectativas seriam defraudadas ${ }^{364}$. Cremos, todavia, que o conceito é de interesse, também, por revelar o paralelismo com a construção teórica existente no Direito Penal tradicional, permitindo, por meio da reflexão crítica a esta construção, que se busque a diferenciação entre entes coletivos, abrindo espaço, portanto, a uma "apreciação objetiva individualizada" ${ }^{, 365}$ de tais entes, com o possível reconhecimento, por exemplo, de causa de inimputabilidade.

\subsubsection{A culpabilidade corporativa e a evitabilidade de HIRSCH}

\footnotetext{
${ }^{360}$ GÓMEZ-JARA DÍEZ, Carlos. La culpabilidad de..., p. 157.

${ }^{361}$ Neste sentido, bem esclarece LAMPE: "La argumentación de SCHROTH peca de dos círculos viciosos: la empresa tiene capacidad jurídica de acción porque se le pueden imputar jurídicamente como propias las acciones de sus funcionários; y tiene capacidad de culpabilidad porque lo mismo es posible en el pleno de la culpabilidad. Cómo se fundamentan dichas imputaciones y por qué conducen dichas imputaciones a las acciones propias y a la culpabilidad propia de la persona jurídica, permanece borroso." LAMPE, Ernst Joachim. La dogmática jurídico-penal..., p. 159.

${ }^{362}$ GÓMEZ-JARA DÍEZ, Carlos. GÓMEZ-JARA DÍEZ, Carlos. La culpabilidad de..., p. 163.

${ }^{363}$ Id. Ibid., p. 163.

${ }^{364}$ Id. Ibid; , p. 163

${ }^{365}$ Adotamos, aqui, a nomenclatura empregada por ROTH na crítica a um conceito de "empresa média". Afirma o autor: "La empresa media no existe como tampoco el individuo médio, y la responsabilidade de Nestlé no podrá ser estabelecida de la misma manera que la del pequeno establecimiento industrial de la Vallé de Joux. La apreciación "objetiva individualizada” que se aplica a los indivíduos puede, sin embargo, ser adoptada al nível de las colectividades.”. ROTH, Robert. Responsabilidad penal..., p. 196.
} 
A construção teórica de HIRSCH parte, pensa-se, de constatações de realidade. Em primeiro lugar, reconhece a capacidade de ação da pessoa jurídica como derivada da estrutura do ente coletivo, que é uma realidade, traduzindo tal ação como própria de seus órgãos ou representantes (somente aqueles com capacidade delitiva que atuam em nome da empresa). Justifica tal interpetaçao tendo em conta a legislaçao alemã, mas especificamente o $\S 30 \mathrm{da} \mathrm{OWiG}$, que reconheceu as pessoas jurídica como capazes de infringir as normas e, portanto, como destinatárias de tais regras ${ }^{366}$.

Ao voltar seus olhares para a culpabilidade, mais uma vez lança mão da realidade social para fundamentá-la. Constata que na linguagem cotidiana há o reconhecimento de uma culpabilidade da pessoa jurídica, ao se falar, por exemplo, da culpa de um Estado por uma guerra, ou de uma empresa pela poluição. Assim, a realidade social formula juízos éticos sobre as empresas ${ }^{367}$. Essa valoração é justificada, também, pela existência de um "direito à honra" desses entes coletivos, o que representaria, na concepção de HIRSCH, justamente a face inversa da moeda da reprovação moral, no sentido de uma "desonra pela conduta inadequada" 368 .

De outro lado, e aqui demonstrando a referência ao pensamento de TIEDEMANN, HIRSCH constata que inexistem fundamentos para uma distinção qualitativa entre Direito Penal e Direito Contravencional. Para o autor, em qualquer âmbito em que se exija reprovabilidade há a necessidade da formulação de uma valoração ética, sendo impossível uma neutralidade. Dessa forma, o raciocínio aplicável para o reconhecimento da culpabilidade no Direito Contravencional é plenamente transferível ao Direito Penal ${ }^{369}$.

Sua construção teórica, assim, se fundamenta no reconhecimento de uma "culpabilidade corporativa", que se diferencia da mera soma da culpabilidade dos indivíduos que compõem a estrutura empresarial ${ }^{370}$. Sustenta, nesse aspecto, que,

\footnotetext{
${ }^{366}$ Assim constatam BAJO e BACIGALUPO: "Hirsch acepta la capacidad de acción de las personas jurídicas, sosteniendo que las acciones de los órganos o representantes de las personas jurídicas constituyen las acciones propias de las mismas. En este sentidom se admite la acción de la persona jurídica como una acción realizada por otra persona (física). En este caso se trata de una forma de acción determinada por la propia estrutura de la corporación que, por otro lado, contituye una realidad. A su modo de ver, la cuestión de la acción es totalmente independiente de la estrutura del concepto penal de acción, es decir, que es irrelevante que se tome como punto de partida un concepto causal, final o social de acción, ya que no se trata de determinar los elementos estructurales del concepto de acción mismo, sino de la relación de dicho concepto con un sujeto. Por otro lado, el hecho de que el $\S 30 \mathrm{OWiG}$ las reconozca como destinatárias de la norma viene a corroborar, según Hirsch, que las personas jurídicas pueden vulnerar precisamente dichas normas.". BAJO FERNÁNDEZ, Miguel; BACIGALUPO, Silvina. Derecho penal..., p. 131.

${ }^{367}$ Id. Ibid., p. 131.

${ }^{368}$ Sobre isso, ver: GÓMEZ-JARA DÍEZ, Carlos. La culpabilidad penal..., p. 164.

${ }^{369}$ Id. Ibid., p. 164-165.

${ }^{370}$ Constata YACOBUCCI: "Hans Hirsch advierte que, en buena medida, la discusión acerca de la
} 
conquanto a culpabilidade coletiva esteja proibida no Direito Penal, o mesmo não se pode dizer da culpabilidade da pessoa jurídica, na medida em que esta não se confunde com a culpabilidade de seus componentes ${ }^{371}$. A culpabilidade de tais órgãos consistirá no "fato de conexão", levando à indagação, após sua apuração, sobre se havia a possibilidade da pessoa jurídica evitar a sua existência ${ }^{372}$. Aqui se revela, portanto, o conteúdo da culpabilidade da associação, que consistirá justamente na evitabilidade do fato, que, na estrutura empresarial, se traduz na "evitabilidade das deficiências na seleção e supervisão dos representantes, outras falhas organizativas, uma política empresarial criminógena, etc. $^{, 373}$.

Numa primeira análise, parece haver uma clara distinção entre a culpabilidade individual e a da pessoa jurídica, entendendo-se aquela como "evitabilidade" da conduta antijurídica por meio de uma motivação da pessoa física conforme a norma; e esta como a possibilidade do ente coletivo de evitar as deficiências organizativas. Não há, contudo, uma verdadeira distinção quando se verifica que a culpabilidade do ente coletivo demandará a constatação da culpabilidade do órgão que o compõe $\mathrm{e}^{374}$. Em outras palavras, ao se apoiar na apuração do "fato de conexão", remete-se a verificação da face subjetiva do fato para o órgão componente da estrutura empresarial, o que parece negar a existência de uma autonomia de fundamento para a culpabilidade empresarial ${ }^{375}$.

Nesse sentido, concordamos com GóMEZ-JARA DíEZ para quem esse "déficit teórico" se converte em "déficit prático", na medida em que se dificulta a apuração da culpabilidade empresarial (consequentemente, da sua responsabilidade) quando se faz

responsabilidad penal de las personas jurídicas tiene como punto de partida el problema acerca de la posibilidad de ser sujetos de determinación por parte de la norma. Así, sostiene que es posible hablar de la empresa como destinataria de debers cuyo cumplimiento ejecuta a través de las personas físicas que la componen. Por eso señala que en el derecho contravencional las personas jurídicas responden como culpables y son sancionadas. El professor alemán habla en este caso de una culpabilidad de la empresa paralela a la individual.”. YACOBUCCI, Guillermo J. Modelos de atribuición de responsabilidade penal en la empresa. In: YACOBUCCI, Guillermo J. (dir.). Derecho penal empresário. Buenos Aires: B de f, 2010, p. 18.

${ }^{371}$ Nesse sentido, GÓMEZ-JARA DÍEZ, Carlos. La culpabilidad de la persona jurídica. In: BAJO FERNÁNDEZ, Miguel; FEIJOO SÀNCHEZ, Bernardo José; Gómez-Jara Díez, Carlos. op. cit., p. 158.

${ }^{372}$ BAJO FERNÁNDEZ, Miguel; BACIGALUPO, Silvina. Derecho penal..., p. 132.

${ }^{373}$ HIRSCH, Hans-Joachim. Strafrechtlich Verantwortlichkeiten von Unternehmen", in ZStW, 107, 1995, p.313. apud GÓMEZ-JARA DÍEZ, Carlos. La culpabilidad penal..., p. 166.

${ }^{374}$ Como constata GÓMEZ-JARA DÍEZ: “[...] traicionando en parte su própria lógica, este autor alemán exige que para la culpabilidad de una persona jurídica es presupuesto necesário la culpabilidad de um órgano que actúe por ella. Así, dicha exigência viene motivada por el hecho de que la culpabilidad requiere siempre una concreta referencia psíquica al hecho y, claro está - seguiria la argumentación - la persona jurídica carece por si misma de una psique. Se precisa identificar una parte de la corporación donde constatar el lado subjetivo del hecho-dolo e imprudência.” GÓMEZ-JARA DÍEZ, Carlos. La culpabilidad de..., p. 158.

${ }^{375}$ Com relação a estas críticas: GÓMEZ-JARA DÍEZ, Carlos. La culpabilidad penal..., p. 166. 
depender da identificação de uma atuação culpável de seus órgãos ${ }^{376}$.

Não se pode perder de vista, contudo, que a concepção de HIRSCH parte de um conceito de culpabilidade muito vinculado aos indivíduos, pretendendo fundamentar a culpabilidade da pessoa jurídica nessa base individualista ${ }^{377}$, traduzida na aplicação do conceito de "evitabilidade", o que, em certa medida, justificaria essa dificuldade de distinção. Contudo, é inegável a contribuição do autor ao trazer a lume a necessidade de se concretizar a "culpabilidade da organização", o que por ele foi feito questionando se era evitável a deficiência organizativa, não bastando, portanto, o mero dever abstrato de organizar-se de maneira a não produzir o delito ${ }^{378}$.

\subsubsection{A culpabilidade pela condução empresarial de HEINE}

Como um dos mais importantes teóricos da Responsabilidade Penal das Pessoas Jurídicas ${ }^{379}$, HeINE constata que as objeções levantadas em relação à capacidade de ação e de culpabilidade das empresas no Direito Penal derivam da errônea tentativa de se transferir concepções consideradas adequadas à imputação individual para os entes coletivos. A equiparação - equivocada, segundo o autor - entre responsabilidade individual e coletiva (esta última não entendida como a soma das atividades dos particulares que compõem a estrutura empresarial, mas como verdadeira organização complexa e, por isso mesmo, de realidade autônoma em relação aos seus componentes), gera uma aplicação desajustada dessa responsabilidade para ambos, criando quer uma exigências excessiva para os particulares, quer um direcionamento errado para as empresas, acabando, no limite, por ameaçar os próprios fundamentos do Direito Penal individual ${ }^{380}$. Os critérios de imputação existentes nesse último âmbito não são funcionalmente adequados para lidar com realidades complexas em que os indivíduos se diluem no entramado organizativo e em que o ato criminoso singular nem sempre é identificável.

Nesse sentido, HeINE percebe essa equiparação errônea nas construções teóricas de TIEDEMANN e HIRSCH, observando que para ambos os autores a culpabilidade da organização depende da constatação de uma decisão individual incorreta de um

\footnotetext{
${ }^{376}$ Id. Ibid, p. 166.

${ }^{377}$ Sobre isso: GARCÍA CAVERO, Percy. La persona jurídica..., p. 75.

${ }^{378}$ Cf. ROTH, Robert. Responsabilidad penal..., p. 198.

${ }^{379}$ “Uno de los mayores teóricos de la RPPJ, Günter HeINE, realizó a mediados de los años noventa uma importante contribución a la culpabilidad de la persona jurídica.”. GÓMEZ-JARA DÍEZ, Carlos. La culpabilidad de..., p. 160.

${ }^{380}$ HEINE, Günter. La responsabilidad..., p. 63-64.
} 
representante da empresa ${ }^{381}$. Sua proposta, então, encaminha-se para o estabelecimento de um sistema paralelo ao do Direito Penal individual, concebendo-se uma responsabilidade originária da organização, independente dos requisitos e consequências relacionados à culpabilidade penal individual $^{382}$. E, nesse aspecto, a construção de uma culpabilidade própria da pessoa jurídica terá uma importância mais ampla, não apenas como legitimadora da sanção ou limitadora do poder punitivo estatal, mas por demonstrar que esse sistema paralelo se trata, verdadeiramente, de Direito Penal ${ }^{383}$.

Para tanto, HEINE reconhece a culpabilidade como categoria sistemática, ressaltando que seus requisitos são definidos normativamente, tendo-se em conta fundamentos derivados do consenso social, ponderando, ademais, que o conteúdo desse conceito se volta para funções específicas, característica essa constatável mesmo em relação à culpabilidade individual ${ }^{384}$. Dessa forma, para se determinar a culpabilidade da pessoa jurídica deve-se buscar conceber conceitos funcionalmente equivalentes aos presentes no Direito Penal individual. É na busca, portanto, de um conceito análogofuncional ao de culpabilidade individual que o autor alcança a "culpabilidade pela condução da empresa",385.

A dificuldade dessa analogia funcional residiria na determinação de um critério para a definição desse paralelismo. Nesse sentido, HEINE elege a "dimensão temporal" como elemento para tal relação analógica-funcional. Constatando que os casos de que o Direito Penal empresarial deve tratar remetem não à apuração de ações específicas, definidas em um certo momento, mas à deficiências duradouras na previsão dos riscos do desenvolvimento das atividades, conclui que se está diante não de um fato culpável, mas de um estado de fato culpável ${ }^{386}$. Dessa forma, a analogia seria cabível com a ideia da “culpabilidade pela conduta de vida" (no sentido de que a reprovação se dirige a um comportamento, ou melhor, existência incorreta que se protrai no tempo), que se

\footnotetext{
${ }^{381}$ Afirma o autor: "Así, de acuerdo a la teoria de la responsabilidade por la culpabilidade de la organización, elaborada por Tiedemann (concepto de culpabilidad normativo-social: la culpabilidade que debe ser imputada como reproche social específico a la organización misma), la decisión individual errada de un representante, al igual que en la concepción sobre la responsabilidade de Hirsch, es una conditio sine qua non.”. Id. Ibid., p. 64.

${ }^{382}$ Tanto é assim que ADAN NIETO MARTín e CARLOS GÓMEZ-JARA DíEZ reconhecem a proposta teórica de HIRSCH como a tentativa de formulaçao de uma culpabilidade própria das empresas. Sobre isso, ver: NIETO MARTÍN, Adan. La responsabilidad penal..., p. 134 e ss. GÓMEZ-JARA DÍEZ, Carlos. La culpabilidad penal..., p.191.

${ }^{383}$ HEINE, Günther, La responsabilidad..., p. 66-67.

${ }^{384}$ Id. Ibid., p. 67.

${ }^{385}$ Id. Ibid., p. 67-68.

${ }^{386}$ Id. Ibid, p. 68.
} 
converteria, para o ente coletivo, numa "culpabilidade pela condução da empresa"387.

Para o autor, as empresas devem ser consideradas como "garantes de controle" ${ }^{388}$, com deveres de gerenciar os riscos próprios da atividade que desenvolvem ${ }^{389}$. Assim, é a partir dessa definição da posição de garante que se delineiam os critérios que orientarão a responsabilidade penal do ente coletivo, os quais podem ser resumidos em dois aspectos: a existência de uma "administração incorreta do risco" e a "materialização do perigo típico da empresa" ${ }^{390}$. Entende HeINE que tal construção permite que, sem o recurso à constatação de comportamentos individuais, haja a manutenção dos elementos essenciais do Direito Penal, por ele traduzidos como o "dever de responder pelo desvalor do resultado", causado por "empresas concretas" de modo "culpável” e "imputável"391.

Numa interessante dissecação das categorias do Direito Penal, o autor identifica como condição objetiva de punibilidade a materialização dos perigos típicos da empresa (resultados) ${ }^{392}$, que se dá como consequência de processos acumulativos derivados da deficiência organizativa ${ }^{393}$. Por outro lado, pela teoria do aumento do risco próprio das organizações concebe uma relação (não causal estrita) entre esta condição objetiva de punibilidade e a administração deficiente que gerou o risco ${ }^{394}$.

Em relação aos elementos subjetivos como o dolo, a culpa e a consciência da

\footnotetext{
${ }^{387}$ Afirma HEINE: "Esta perspectiva de largo plazo gana en precisión mediante la responsabilidade integral de la emrpesa por investigación, planeamento, desarrollo, producción y organización. Quién otro que aquéllos que sistemáticamente generam y se aprovechan de los nuevos riesgos, que disponem de un conocimiento y poder especial, deben assumir esta responsabilidade especial?". Id. Ibid., p. 68.

${ }^{388}$ Segundo o autor: "Una empresa, dedicada a la prosucción de nuevos riesgos técnicos, debería de ser considerada (paralelamente a la responsabilidade penal individual por la dirección del establecimiento) como garante de control. Los deberes de evitar peligros y de controlar resultan del hecho que llos riesgos propios de la explotación pueden ser unicamente controlados mediante una administración de los riesgos por parte de la empresa y no mediante controles estatales o disposiciones de seguridade.”. Id. Ibid., p. 69.

${ }^{389}$ Para NIETO MARTín, aliás, o modelo teórico de HEINE se restringe aos grandes riscos, remetendo, portanto, a questao da responsabilidade penal empresarial a um problema de Parte Especial, assemelhando-se à estratégia do corporate killing do direito inglês, proposta contida na Law Commision Raport n. 237 de 1996, em que se idealiza um delito específico para as pessoas jurídicas de homicídio (conquanto nao aprovado dessa forma). Ver: NIETO MARTíN, Adan. La responsabilidad..., p. 136 e 128.

${ }^{390}$ HEINE, Günther. La responsabilidad..., p. 69

${ }^{391}$ Id. Ibid., p. 69-70.

${ }^{392}$ Para NIETO MARTíN, a materialização dos perigos constitui condição objetiva de sanção e não resultado do delito empresarial. NIETO MARTÍN, Adan. La responsabilidad..., p. 137.

${ }^{393}$ Analisando a proposta doutrinária de HeINE, constata NIETO MARTín: "Las personas fiscas desaparecen y se acoge un modelo de 'causalidade relajada'. A la empresa no se imputa nengún delito, lo que exigiría del comportamiento de una persona física. La propuesta significativamente no habla ni de homicidio, ni de delito ecológico, sino de muertes, daños, peligros, etc. La estructura típica del precepto es además relativamente sencilla: un control defectuoso del riesgo característico de la actividade empresarial que se realiza en un acontecimiento especialmente grave, el disturbio empresarial. Este último elemento constituye una 'condición objetiva de sanción' y no el resultado del delito empresarial. La relación entre ambos elementos se establece a partir de una teoría similar a la del incrimento del riesgo, desechándose fórmulas causales estrictas, como la teoría de la condición.”. Id. Ibid., p. 136-137.

${ }^{394}$ HEINE, Günther, La responsabilidad..., p. 70.
} 
ilicitude, afirma que são determinados conforme critérios sociais, reconhecendo que, nesse aspecto, acabam sendo mais facilmente constatáveis para as pessoas jurídicas do que para os indivíduos, trazendo como exemplo a possibilidade mais real e facilitada de se demonstrar o conhecimento, pelo ente coletivo, das inúmeras normas jurídicas existentes, em comparação às pessoas físicas ${ }^{395}$.

No que atine à "culpabilidade pela condução da empresa", ressalta o autor que deverá o julgador demonstrar que considerou a "individualidade" do ente coletivo concreto para apurar deficiências organizativas ou de cultura empresarial ${ }^{396}$. Nesse aspecto, a busca por tal individualização parece refletir uma maior aproximação com o sentido funcionalmente possuído pela culpabilidade.

É importante ressaltar, contudo, que o conceito de culpabilidade empresarial de HEINE não tem em conta apenas a dimensão temporal da atuação do ente coletivo que impossibilita a remessa a uma decisão concreta determinada. Ressalta o autor, também, que a empresa possui uma competência específica na realidade social moderna. Na medida em que se desenvolvem por meio de inovações tecnológicas geradoras de risco, e sendo elas as detentoras do conhecimento dessas inovações, com verdadeiro monopólio, às empresas cabe o controle adequado de tais riscos ${ }^{397}$, o que justifica sua responsabilização ${ }^{398}$. HEINE enfatiza, portanto, dois aspectos em sua construção: a dimensão temporal e a atitude empresarial, havendo um "exercício deficiente do poder de organização das estruturas empresarias em decorrência de uma concreta atitude empresarial" 399 .

Essa concepção de culpabilidade apresenta algumas vantagens, por pretender desvincular a culpabilidade individual da coletiva, buscando a construção de um

\footnotetext{
${ }^{395}$ Constata o autor: "Los elementos subjetivos en el derecho penal ya no se establecen como un conocimiento real del autor, sino que se fijan de acuerdo a criterios sociales. Su imputación a una empresa es en realidad menos problemática que en el caso de una persona natural. Mientras que en el caso de un autor individual la presunción de la existência del conocimiento jurídico relacionado a la multitud de reglas relativas a seguridade existentes se hace cada vez más ficta, la imputación correspondiente a las empresas es más real, a condición que se pueda imputar, igualmente, a la empresa autora en su conjunto el conocimiento poseído por sus secciones legal y de seguridade". Id. Ibid., p. 70.

${ }^{396}$ Id. Ibid., p. 71.

${ }^{397}$ Evidenciando, ao que se pensa, uma fundamentação pautada na autorregulaçao.

${ }^{398}$ HEINE, Günther. op. cit., p. 69. Sobre isso, ver também: GÓMEZ-JARA DÍEZ, Carlos. La culpabilidad penal..., p. 189-190.

${ }^{399}$ É o que afirma GÓMEZ-JARA DíEZ: "Como ya se desprende de esta definición e incluso del próprio concepto, la culpabilidad por la conducción empresarial pone énfasis notable, por um lado, em la dimensión temporal y, por outro, en un tema recurrente: la "actitude empresarial". Así, la mayoría de los casos que trata el Derecho penal de la persona jurídica, segun HEINE, son el resultado de inadecuaciones operacionales que no se pueden reconducir a decisiones individuales, pero que se corresponden generalmente con déficits en el cuidado del contro del riesgo que há generado consecuencias sociales negativas. El control organizativo será defectuoso cuando la persona jurídica haya omitido implementar estratégias a lo largo del tiempo que minimicen riesgos y no haya introducido programas preventivos en su planeamiento.”. GÓMEZ-JARA DÍEZ, Carlos. La culpabilidad de..., p. 160.
} 
equivalente funcional, o que permitiria um tratamento mais adequado para a responsabilização criminal de ambos os agentes (pessoa física e jurídica), impedindo que se recorra a uma ampliação da responsabilidade individual, e reconhecendo a necessidade de se exigir do ente coletivo maior responsabilidade em face de seus conhecimentos técnicos. Por outro lado, a responsabilização criminal do ente coletivo, em tese, não vai se ver afetada pelas dificuldades de se apurar a responsabilidade individual, respondendo, portanto, de forma mais adequada aos fundamentos político-criminais que justificariam a adoção da responsabilidade penal da pessoa jurídica ${ }^{400}$.

Acentua-se, também, que a formulaçao teórica de HEINE apresenta uma contribuição técnica por analisar com "categorias jurídicas continentais" uma construção como a culpabilidade da empresa, que seria proveniente do pensamento jurídico anglosaxão $^{401}$.

Todavia, algumas críticas foram formuladas em face dessa concepção teórica. Em primeiro lugar, deve-se ressaltar que alguns vêem problemas na fundamentação metodológica adotada por HEINE. Isto porque, conquanto faça menção à busca por um conceito análogo-funcional à culpabilidade individual, o que verdadeiramente sua teoria de culpabilidade empresarial teria alcançado seria uma formulação voltada para a deficiência organizativa. Em outras palavras - e talvez melhor esclarecendo -, não se teria construído um conceito semelhante ao de culpabilidade individual (no caso, a culpabilidade pelo caráter), uma vez que o conteúdo da culpabilidade coletiva, no sentido da existência de um comportamento defeituoso cujas consequências são previsíveis, não encontra paralelo na responsabilidade penal individual ${ }^{402}$.

A pretendida analogia teria fracassado também ao se fundar na culpabilidade pelo caráter. Afinal, esse paralelo não seria servível como fundamento para se ter um verdadeiro Direito Penal na responsabilização da empresa, na medida em que esse conceito

\footnotetext{
${ }^{400}$ Constata GÓMEZ-JARA DíEZ: "En consecuencia, el planteamiento de HEINE favorece el desarollo de la autorresponsabilidad empresarial. En resumidas cuentas, las ventajas que, a juicio del próprio HeINE, brinda su concepto de culpabilidad son la siguientes. En primer lugar, facilita una responsabilidad corporativa coherente, independentemente de las dificultades que, debido a las lagunas estructurales, surjan para identificar un individuo. En segundo lugar, se opone a cualquier tipo de regulación que busque ampliar la responsabilidade penal individual por el solo hecho de adquirir mayor influencia sobre la empresa. En tercer lugar, enfatiza que se pude exigir mucho más de una empresa con un conocimiento técnico especial que de um individuo.”. GÓMEZ-JARA DÍEZ, Carlos. La culpabilidad penal..., p. 191.

${ }^{401}$ Isto é o que constata NIETO MARTín, ao pontuar que a proposta doutrinária de Heine é interessante por motivos técnicos: "[...] ayuda a analizar com categorias jurídicas continetales, na construcción, la culpabilidade de empresa que, tal como estamos comprobando, procede del mundo anglosajón.". NIETO MARTÍN, Adan. La responsabilidad..., p. 135.

${ }^{402}$ Nesse sentido: OTTO, Hans-Jochen. Die Haftung für kriminelle Handlungen in Unternehmen. In: Jura, 1998, p. 416. apud. GÓMEZ-JARA DÍEZ, Carlos. La culpabilidad penal..., p. 191.
} 
é rechaçado pelo próprio Direito Penal individual moderno ${ }^{403}$. Assim, estar-se-ia partindo de critérios já ultrapassados e que não são admissíveis como ponto de apoio teórico para a responsabilidade penal, sobretudo porque se busca um equivalente funcional, e a culpabilidade pelo caráter é funcionalmente repudiada por demonstrar uma valoração do modo de $\operatorname{ser}^{404}$, um Direito Penal do autor, e não do fato. Há, contudo, quem não perceba na adoção de um Direito Penal de autor no específico campo do Direito Penal das empresas qualquer problema ${ }^{405}$, na medida em que o Estado teria a possibilidade de dizer aos entes coletivos como se organizar ou como se conduzir (diversamente da relação entre Estado e indivíduo, onde se garante o livre desenvolvimento de sua personalidade ${ }^{406}$. E desse aspecto derivaria uma grande contribuição teórica para a formulação de uma culpabilidade empresarial, ao se reconhecer uma dimensão temporal peculiar dessa culpabilidade, que vai se apoiar num defeito de organização permanente, e não num comportamento delitivo pontual ${ }^{407}$, interpretado, aliás, como um fim garantista ou limitador da intervenção penal, ao não permitir que esta se contente com a mera constatação de um fato delitivo pontual, sem demonstrar uma falta de organização continuada $^{408}$.

\subsubsection{A culpabilidade pelo caráter da empresa de LAMPE}

Mais do que apresentar uma leitura alternativa ao conceito de culpabilidade para as pessoas jurídicas, o desenvolvimento teórico de LAMPE põe um olhar crítico sobre o discurso dogmático vigente. Diante da percepção de carências práticas no Direito Penal Econômico, resultantes do emprego de um instrumental inadequado para lidar com a delinquência sistêmica, porquanto baseado na autoria individual ${ }^{409}$, o autor propõe uma

\footnotetext{
${ }^{403}$ Essa crítica é bem desenvolvida em GÓMEZ-JARA DÍEZ, Carlos. La culpabilidad penal..., p. 192-193.

${ }^{404}$ Sobre a culpabilidade pelo caráter, conferir capítulo terceiro, item 3.4.5.

${ }^{405}$ NIETO MARTÍN, Adan. La responsabiidad..., p. 150.

${ }^{406}$ Id. Ibid., p. 151.

${ }^{407}$ Nesse sentido, apoiando-se nessa contribuição teórica de HEINE (e de LAMPE também, que se voltou para um direito penal do autor em sua formulação de culpabilidade empresarial, como veremos) e na sua influência sobre o aspecto temporal da culpabilidade, NIETO MARTín entende que se deve apurar um comportamento pré-delitivo e pós-delitivo da empresa, comportamentos estes que devem ter caráter permanente. NIETO MARTÍN, Adan. La responsabilidad..., p. 150-155. Teremos oportunidade de detalhar essa formulação doutrinária mais a frente, no item 5.1.14.

${ }^{408}$ Id. Ibid., p. 152.

${ }^{409}$ Afirma o autor: "[...] el quid de la cuestión radica en que, hasta ahora, la dogmática penal ha reaccionado frente a todo tipo de delincuencia sistémica con un instrumentário hecho a la medida del autor individual. Sus categorias fundamentales - acción individual, resultado social y la causalidade que los vincula - resultan sumamente simplistas en relación con la complejidad de los supuestos de hecho a enjuiciar.”. LAMPE, Ernst-
} 
mudança de paradigma. Percebe ele que para o "injusto de sistema", os cursos e ações causais lineares, ou mesmo uma pretendida equivalência de elementos, não concedem critérios de imputação adequados para os sistemas complexos ${ }^{410}$. Assim, seria necessária uma complementação da dogmática, com o desenvolvimento de uma teoria de "injustos de sistemas" para os "sistemas de injusto" 411.

Define como sistemas de injustos jurídico-penais as construções sociais em que as relações entre indivíduos são organizadas para um fim social injusto ${ }^{412}$. Diferencia os sistemas de injusto simples, que se traduziriam na coautoria (organização para um fim comum por meio da vontade dos indivíduos nele contidos) ${ }^{413}$, dos sistemas de injusto constituídos, sistemas complexos formalmente organizados, dotados de configuração duradoura não afetada pela alteração de seus componentes, com comunicação e interação hierárquica (subsistemas) ${ }^{414}$.

Dentre os sistemas de injusto constituídos importa para a presente análise as empresas econômicas com tendências criminais ${ }^{415}$, unidades organizativas que servem a um fim econômico cuja persecução pode demonstrar uma tendência criminosa ${ }^{416}$. Aliás, LAMPE aponta uma característica interessante desse tipo de sistema de injusto que é o fato de que, quanto mais isolada a empresa das influências normativas externas, o que se dá com a construção de uma moral interna própria, mais facilitada a integração de atitudes criminosas no bojo empresarial $^{417}$.

Deve-se esclarecer, contudo, que se o fim de uma empresa for, em si, criminoso, não estaríamos diante desse tipo de sistema de injusto constituído, mas de um "agrupamento criminal" "418. Assim, o injusto de sistema nas empresas é acidental, produzido pela existência de uma deficiência na organização da empresa ou pela presença de uma filosofia empresarial criminógena, entendida quer como o favorecimento da atitude

\footnotetext{
Joachim. La dogmática..., p. 101.

${ }^{410}$ Id. Ibid., p. 102.

${ }^{411}$ Id. Ibid, p. 103.

${ }^{412}$ Id. Ibid., p. 103.

${ }^{413}$ Id. Ibid., p. 104-111.

${ }^{414}$ Id. Ibid., p. 111-114.

${ }^{415}$ Além das empresas econômicas com tendências criminais, LAMPE aponta como sistemas de injusto constituídos os agrupamentos criminais e os Estados ou estruturas estatais pervertidas criminalmente. Id. Ibid., p. 114-122.

${ }^{416}$ Id. Ibid., p. 117.

${ }^{417}$ Consigna o autor: “[...] los fines de la empresa son generalmente limitaciones, relativamente abiertas, del margen de acción y, por lo tanto, también se permite la integraciónde "actitudes criminales". Dichas actitudes se desarrollan mejor cuanto más se aísle a la empresa de las influencias normativas externas a través de una moral interna.". Id. Ibid., p. 117-118.

${ }^{418}$ Id. Ibid, p. 129.
} 
criminosa para o alcance de resultados, quer como a redução da barreira psicológica para o atuar antijurídico no seio da estrutura empresarial ${ }^{419}$. Nesses dois casos, revela-se a dimensão sistêmica do injusto. Assim o injusto de sistema na empresa se daria pela existência de formas de comportamento que lesionam bens jurídicos ou por concordarem com a filosofia empresarial, ou por serem favorecidas pela deficiência organizativa da empresa $^{420}$.

Segundo LAMPE, o injusto de sistema não necessita de manifestações externas através de ações, sendo um estado de injusto em si, que pode, contudo, confirmar-se por ações $^{421}$. Basta que se constate, no caso das empresas, um potencial de risco (pessoal e técnico) que se acumula nos sistemas; uma integração defeituosamente organizada que põe em perigo um bem jurídico; uma consciência defeituosa de responsabilidade por parte das pessoas vinculadas organizativamente na empresa; e a existência de imprudência ${ }^{422}$. Assim, enquanto nos delitos de ação (individuais) a predisposição ao injusto compõe a culpabilidade, nos sistemas de injusto a predisposição ao injusto constitui o próprio injusto de sistema ${ }^{423}$.

É interessante, entretanto, a ressalva feita pelo autor em relação à punibilidade dos injustos de sistema. Não bastaria a configuração do injusto de sistema para haver a punição. $\mathrm{O}$ merecimento e a necessidade da pena dependerão da constatação de que tais injustos contrariam valores ético-sociais e são eficazes para a desestabilização social. Assim, no caso das empresas econômicas com tendência criminal, o caráter imprudente de uma organização ou filosofia empresarial apenas indicará a necessidade da sanção quando desses elementos resultem ações dotadas de uma periculosidade social insuportável, até para que não haja o sancionamento das empresas por seu mero funcionamento ${ }^{424}$.

Para se apurar o conteúdo da culpabilidade empresarial, entende LAMPE ser necessário definir o conteúdo do injusto, na medida em que entende este como culpabilidade a realizar ${ }^{425}$. Assim, como o injusto de uma filosofia empresarial criminógena ou de uma organização deficiente está no âmbito ético-social, também aí está

\footnotetext{
${ }^{419}$ Id. Ibid, p. 130.

${ }^{420}$ Id. Ibid, p. 131.

${ }^{421}$ Afirma LAMPE: "El injusto del sistema es un estado de injusto en sí, que puede confirmarse en acciones, pero que no tiene necessariamente por qué.”. Id. Ibid, p. 139.

${ }^{422}$ Estes são os quatro fatores que, para Lampe, constituem as características comuns do injusto de sistema. Id. Ibid, p. 137-139.

${ }^{423}$ Id. Ibid, p. 139-140.

${ }^{424}$ Id. Ibid, p. 140.

${ }^{425}$ Afirma LAMPE: "El contenido de la culpabilidad depende del contenido del injusto que significa culpabilidad a realizar.”. Id. Ibid, p. 162.
} 
a culpabilidade. LAMPE entende que a responsabilidade, quer para o homem, quer para o sistema social, decorrem da mesma causa: o caráter (ou, melhor dizendo, a decadência de caráter). Assim, a decadência de caráter pessoal fundamenta a culpabilidade individual, enquanto a decadência de caráter social fundamenta o injusto. Mas como o injusto deve ser entendido como culpabilidade a realizar, é evidente que a culpabilidade empresarial é consequência de um caráter empresarial defeituoso ${ }^{426}$, expresso na presença de uma filosofia criminógena ou de uma estrutura organizativa deficiente.

Tais construções teóricas de LAMPE buscam trazer uma resposta dogmática para se superar o déficit de justiça penal presente na responsabilidade de sistemas. Para alguns, aliás, sua formulação traz a contribuição, tal como HEINE, de revelar a dimensão temporal peculiar da culpabilidade empresarial, que não se limita a apuração de um defeito pontual $^{427}$. Ademais, conseguiria efetuar uma distinção entre a responsabilidade imprudente da empresa (por uma organização defeituosa) e a responsabilidade dolosa (pela

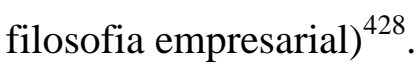

Contudo, algumas objeções são levantadas às suas formulações teóricas, importando-nos, aqui, aquelas relacionadas ao conceito de culpabilidade empresarial.

Em primeiro lugar, critica-se a irreal identidade estrutural construída por LAMPE em relação ao conceito de caráter para a pessoa jurídica e para a pessoa física, havendo, para aquela, segundo os críticos, mera metáfora de caráter, sobretudo para quem entende o caráter apenas como produto da consciência e da consequente capacidade de autorreflexão $^{429}$.

De outra banda, tal como apontado em relação a HEINE, critica-se o emprego de um conceito que não se aceita na dogmática penal moderna mesmo para a

\footnotetext{
${ }^{426}$ Consigna o autor: "La culpabilidad siempre es la consecuencia de un carácter defectuoso. Lo mismo vale para la culpabilidad empresarial: es la consecuencia de un carácter empresarial defectuoso.”. Id. Ibid, p. 162. ${ }^{427}$ Cf. NIETO MARTÍN, Adan. La responsabilidad..., p. 151-152.

${ }^{428}$ Id. Ibid, p. 138. Nesse sentido, aliás, NIETO MARTIN entende que essa distinção que a formulçao dourtinária de LAMPE alcança poderia servir de sustento teórico para o modelo de responsabilidade penal da pessoa jurídica contido no Código Penal australiano, que distingue delito doloso e imprudente de responsabilidade dos entes coletivos.

${ }^{429}$ Essa crítica é feita por V. FREIER, que acredita apenas poder-se falar no "caráter da empresa" de forma metafórica. Cf. FREIER, Friedrich von. Kritk der Verbandsstrafe, p. 144. apud GÓMEZ-JARA DÍEZ, Carlos. La culpabilidad penal..., p. 184. Contudo, olvida-se que LAMPE traz como pressuposto de sua construção a teoria dos sistemas sociais autopoiéticos. Como esclarece GóMEZ-JARA DíEZ: “[...] dicha crítica no tiene en cuenta los puntos de partida que el próprio LAMPE detalla al comienzo de su investigación. En efecot, Lampe incorpora los presupuestos de la teoria de los sistemas sociales autopoiéticos, gracias a la cual resulta relativamente sencillo fundamentar precisamente esa "continuidade propia" del sistema; se trataria de la autopoiesis de dicho sistema. En definitiva, esta critica de V. FREIER se basa en su recurrente presuposición de que unicamente la consciência posse la capacidad de autorreflexión." GÓMEZ-JARA DÍEZ, Carlos. La culpabilidad penal..., p., 184.
} 
responsabilidade individual, qual seja, a "culpabilidade pelo caráter". Assim, restaria dificultada a intenção de harmonização da responsabilidade penal empresarial com o Direto Penal moderno ${ }^{430}$.

\subsubsection{A culpabilidade pela reprovabilidade ético-social de DANNECKER}

A construção de DANNECKER, trazida a baila no início do século XXI, parte da distinção entre culpabilidade individual e culpabilidade da pessoa jurídica, enxergando nesta última estrita conexão com a ideia de responsabilidade social ${ }^{431}$, com um conteúdo de reprovação, portanto, diverso e independente da culpabilidade individual, entendido como reprovação "ético-social" e não "ético-individual”, fundado na existência de uma filosofia empresarial insuficiente ou em uma estrutura organizativa deficitária ${ }^{432}$.

Sua concepção parte de uma vinculação entre o injusto e a culpabilidade, entendendo que, se o primeiro é caracterizado por uma organização defeituosa e uma ética empresarial deficiente, evidente que a culpabilidade consistirá na não criação de condições necessárias para evitar a realização do injusto. Assim, a responsabilidade da pessoa jurídica se dará pelas "prestações coletivas defeituosas" derivadas da deficiência na estrutura organizativa empresarial ou da própria ética adotada pelo ente coletivo ${ }^{433}$.

Perceba-se, ademais, que, ao reconhecer a distinção entre culpabilidade da pessoa jurídica e individual, DANNECKER ressalta que aquela não se fundará no poder agir de outro modo, capacidade que não admite ter o ente coletivo. Assim, tendo-se em conta que a ética da pessoa jurídica é uma ética social, o conteúdo da reprovação é justamente a falta de correção do sistema. Atuando a pessoa jurídica para a consecução de determinados fins, pode-se exigir que em tal atuação se submeta a exigências éticas que devem pautar seus objetivos e sua organização. Bem por isso, se essa atuação se desviar dessas exigências, é possível reprovar a pessoa jurídica por não ter criado os pressupostos necessários (seja pela presença de certa filosofia empresarial, seja pelo alcance de certa estrutura organizativa) para evitar a prática delitiva em seu bojo.

Presente esse raciocínio, é possível concluir que a demonstração de uma estrutura organizativa ou de uma filosofia empresarial escorreita, ainda que realizado o

\footnotetext{
${ }^{430}$ Id. Ibid, p. 184.

${ }^{431}$ GÓMEZ-JARA DÍEZ, Carlos. La culpabilidad de..., p. 161.

${ }^{432}$ Id. Ibid., p. 161.

${ }^{433}$ Id. Ibid., p. 161.
} 
injusto, ao negarem a presença da culpabilidade empresarial, consistiriam justamente em causa de exculpação ${ }^{434}$. Parece, contudo, que a construção de DANNECKER não consegue fugir das críticas relacionadas à confusão entre injusto e culpabilidade.

\subsubsection{A culpabilidade fundada no comportamento pós-delitivo (reactive fault) de FisSe e Braithwaite.}

A proposta de FISSE e BRAITHWAITE demonstra uma reestruturação no esquema do direito penal. Não vislumbram na responsabilidade penal da empresa uma relação direta entre ação e sanção, característica do direito penal individual, mas incorporam um ingrediente a ser apurado: a reação da empresa à ação individual ${ }^{435}$.

A concepçao teórica desses autores traz uma verdadeira reformulação da culpabilidade fundada especialmente em seu aspecto temporal. Sua apuração será determinada por um ponto de vista ex post ${ }^{436}$, ou seja, pela constatação do comportamento empresarial pós-delitivo.

Deve-se consignar, contudo, que essa é uma das facetas da culpabilidade para os aludidos autores. Em outras palavras, FISSE e BRAITHWAITE não descuram da possibilidade de haver a responsabilidade criminal do ente coletivo também pela constatação de que ao tempo da prática delitiva em seu bojo, ou antes mesmo dela, a empresa formulou uma política interna de não obediência a deveres legais (noncompliance), ou foi negligente, não buscando adotar medidas para evitar violações já anteriormente ocorridas ${ }^{437}$. Contudo, vão ressaltar a culpabilidade em seu aspecto reativo pela percepção de que, em muitos casos, será difícil constatar essa "culpa antecedente" da pessoa jurídica, conquanto tenha havido a prática de delito em nome ou no interesse da

\footnotetext{
${ }^{434}$ Id. Ibid., p. 162.

${ }^{435}$ Nos valemos, aqui, dos esquema utilizado por NIETO MARTín para explicar essa alteração teórica. Cf. NIETO MARTÍN, Adan. La responsabilidad..., p. 139.

${ }^{436}$ Id. Ibid., p. 139.

${ }^{437}$ Afirmam os autores: "The most critical point is that corporate criminal responsability can be imposed on two bases: first, initial fault, and second, reactive fault. Situations can arise where a corporation is palpably at fault ato $\mathrm{r}$ before the time when the actus réus of an offence is committed. Thus, Essence Corpp may formulate a policy of non-compliance with a requirement imposed under antipollution or antitrust criminal Law, as where the directors decide that the fines imposed for a violation are likely to fall well short of the savings from non-compliance. Alternatively, it may be the case that the corporation has behaved in a grossoly negligent way, as by failing to heed compaints about similar violations in the past, or clar warnings that its operating system were inadequate. Where there is sufficient evidence against a corporation of initial fault in the sense indicated then the Accountability Model holds that liability should be imposed on the basis". FISSE, Brent. BRAITHWAITE, John. Corporates, crime and accountability. Cambridge: Cambridge University Press, 1993, p. 162.
} 
empresa $^{438}$.

Nesse sentido, diante da complexidade em se demonstrar uma "intenção" da empresa de delinquir, e tendo-se em conta as preocupações essencialmente pragmáticas dos autores, eles vão buscar fundar a culpabilidade da empresa em sua reação ao delito cometido em seu bojo, ou seja, na adoção de medidas corretivas e preventivas (prevenção voltada para novos delitos futuros) adequadas. É o que denominam de reactive corporate fault $^{439}$. Voltam-se as preocupações, no delineamento da culpabilidade empresarial, para a forma como a empresa procede após a comissão de um delito em sua estrutura, e não para as medidas de prevenção que já se faziam presentes no ente coletivo. Há, portanto, a construção de uma culpabilidade reativa.

A reprovação, desse modo, se dirige a um comportamento posterior ao crime, com uma completa inversão da dimensão temporal da culpabilidade que se apura no direito penal individual. Com isso, também, é inegável que vai se remeter a apuração do dolo e da antijuridicidade de forma ex post ${ }^{440}$.

Como se disse, a adoção dessa racionalidade guarda relação com as próprias preocupações pragmáticas de FISSE e BRAITHWAITE, derivadas da constatação das dificuldades de aplicação prática da responsabilidade penal empresarial no âmbito do direito norteamericano. Sua racionalidade, portanto, relaciona-se com a ideia de que a adoção de medidas reativas após o delito teria o condão de expressar um maior comprometimento futuro da empresa com a prevenção de danos similares ${ }^{441}$, mostrando-se em perfeita sintonia com a atenção crescente que tem se dado à disciplina interna e à reforma institucional das empresas ${ }^{442}$.

Parece-nos acertado o raciocínio de FISSE e BRAITHWAITE no sentido de ressaltar, no dimensionamento da responsabilidade penal da pessoa jurídica, o aspecto pósdelitivo, ou seja, dar especial importância às medidas tomadas pela empresa após o

\footnotetext{
${ }^{438}$ Constatam: "More typically, there will be insufficient evidence of initial corporate fault but ample evidence that the actus reus has been committed on behalf of the corporation. The Accountability Model recognises this fact of corporate regulation by providing a structure that allows corporate criminal liability to be imposed on the bases of reactive fault. The broader timeframe is more realistic because it takes into account everyday notions of corporate responsability for what corporations do, or fail to do, after their activities lead to injury or harm.”. Id. Ibid., p. 162.

${ }^{439}$ Segundo a definiçao de FISSE e BRAITHWAITE: “[...] the concept of reactive corpoate fault, by which is meant a deliberate or negligent corporate faillure to comply with a reactive duty to mount an effective program of internal disciplinary action, institutional reform or compensation.” Id. Ibid., p. 146.

${ }^{440}$ NIETO MARTÍN, Adan. La responsabilidad..., p. 140.

${ }^{441}$ Id. Ibid., p. 140.

${ }^{442}$ Assim consignam: “[...] the increasing attention paid to internal discipline and institutional reform in the context of corporate sentencing heralds the emergence of reactive corporate fault as a basis of corporate criminal liability.”. FISSE, Brent. BRAITHWAITE, John. Corporates..., p. 163.
} 
advento do fato criminoso em seu bojo. Não parece, contudo, que a assunção desse aspecto deva ser feita na determinação do conteúdo da culpabilidade, traduzindo-a como "culpabilidade reativa". A bem da verdade, crê-se que a construçao de uma culpabilidade própria das pessoas jurídicas, se pode demandar uma avaliação temporal peculiar dessa culpabilidade, não remeterá, contudo, a uma apuração prospectiva, que, ao que parece, acaba por negar o próprio sentido da culpabilidade como reprovação pelo comportamento delitivo alcançado, e não como reprovação pela não adoção de medidas reativas conectadas ao passado, e preventivas voltadas ao futuro em face de ação danosa já praticada. Nesse último aspecto, aliás, a culpabilidade parece se converter em periculosidade.

Assim, se pragmaticamente a reação da empresa ao fato delitivo deve ter algum valor em sua responsabilização penal, crê-se que isto deva ocorrer no dimensionamento da reprimenda. Contudo, é indubitável que as considerações de FISSE e BRAITHWAITE têm seu contributo ao determinar que a definição teórica de uma culpabilidade empresarial não pode se alienar de seu aspecto prático.

\subsubsection{A responsabilidade penal da pessoa jurídica em JAKOBS: mudanças de posicionamento e contribuição para uma culpabilidade empresarial.}

O posicionamento de JAKOBS em relação à admissão da responsabilidade penal da pessoa jurídica pode ser cindido em dois momentos: a antiga opinião de JAKOBS, em seu Tratado, que admitia tal responsabilidade ${ }^{443}$, e sua posição atual, em que, revendo seu posicionamento, negou a responsabilidade penal da pessoa jurídica ${ }^{444}$.

\footnotetext{
${ }^{443} \mathrm{Em}$ seu Tratado, JAKOBS constatou que, injustamente, a doutrina dominante negava a reponsabilidade penal da pessoa jurídica, observando que os fundamentos de tal posição residiriam em dois aspectos principais: a incapacidade de ação e a incapacidade de culpabilidade. Para o autor, contudo, não haveria grandes distinções em relação à apuração dessas duas características entre as pessoas físicas e as jurídicas. Em relação à ação, afirmava que mesmo para as pessoas físicas, sua comprovação não dependia de um ponto de vista exclusivamente naturalístico, e sim o importante seria a determinação valorativa do sujeito da imputação. Assim, não interessaria o componente interno, quer na pessoa física, quer na jurídica, mas seu output, de forma que as ações dos órgãos baseadas no estatuto das pessoas jurídicas seriam ações próprias dessas últimas. Já no que atine à culpabilidade, JAKOBS percebe que esta é mais difícil de determinar com relação aos entes coletivos. Acaba pronunciando-se, é bem verdade, sobre os aspectos negativos deste elementos, asseverando que, tal como na pessoa física, é possível verificar situações em que a pessoa jurídica atua, mas as condições internas da ação estão indisponível (por exemplo, quando um órgão componente da pessoa jurídica atue, mas em desacordo com a competência que lhe fora definida no estatuto dessa pessoa jurídica). Nesse casos, haverá a exculpação do ente coletivo. Conclui JAKOBS, então, que, "tanto para a ação como para a culpabilidade, são idênticas as formas dogmáticas (e não só os nomes) na pessoa física e na jurídica”. JAKOBS, Günter. Derecho penal..., p. 182-184.

${ }^{444}$ JAKOBS, Günter. Strafbarkeit juristischer Person? In: Festschrift für Klaus Lüderssen. Baden-Baden: 2002, p. 559 e ss. apud ORCE, Guillermo. Responsabilidad penal de las personas jurídicas. In: El funcionalismo en derecho penal. Libro homenaje al profesor Günther Jakobs. v. II. Colombia: Univerisdad
} 
Parece-nos importante, num primeiro momento, destacar os pontos de objeção levantados por JAKOBS que o fizeram alterar sua concepção, revelando, por sem dúvida, os desafios que se colocam para o reconhecimento da responsabilidade penal da pessoa jurídica. E, nesse aspecto, sobressai a culpabilidade como elemento crítico a ser tratado.

Numa síntese, pode-se dizer que as objeções de JAKOBS à responsabilidade penal da pessoa jurídica se resumem a dois aspectos: a inexistência de uma identidade entre a pessoa que realiza o fato e aquela que será apenada; e a inexistência de uma autoconsciência na pessoa jurídica que permita comunicar uma tomada de postura frente à norma de forma a se reconhecer que seja capaz de negar-lhe sua vigência ${ }^{445}$.

Em ambas as objeções, ao que parece, parte-se da ideia de que a responsabilidade penal da pessoa jurídica só poderia estar baseada num modelo vicarial, de imputação derivada, recorrendo-se à teoria do alter ego ${ }^{446}$. Afinal, falar-se na inexistência de identidade entre o autor material da ação e aquele que será sancionado é partir da premissa de que tal sanção se fundará na imputação de ação alheia; de igual modo, reconhecer que a pessoa jurídica é incapaz de comunicar por si própria uma postura frente à norma, é admitir que qualquer comunicação nela produzida pertence aos seus órgãos, e não a ela mesma.

Esse primeiro destaque crítico às objeções trazidas por JAKOBS já revela uma grande contribuição produzida pela discussão em face de seu pensamento avesso à responsabilidade penal da pessoa jurídica: o reconhecimento de que uma modalidade de responsabilidade vicarial é deficiente para fundamentar a responsabilização criminal autônoma (própria) do ente coletivo. Esse modelo teórico mostra-se, ao que se pensa, como o produtor das deficiências apontadas por JAKOBS a essa modalidade de responsabilização penal.

É claro que não podemos restringir nossos olhares a esta constatação. Afinal, as críticas de JAKOBS, conquanto perfeitamente dirigidas a um modelo teórico específico de responsabilização, não se limitam a ele. E, nesse aspecto, salta aos olhos a crítica à incapacidade comunicativa da pessoa jurídica pela inexistência de uma autoconsciência, essencialmente ligada à sua noção de culpabilidade.

Nesse aspecto, parece-nos interessante as objeções feitas por GUILLERMO ORCE. Em primeiro lugar, deve-se observar o papel que a autoconsciência desempenha no

Externado de Colombia, 2003, p. 369.

${ }^{445}$ Sobre isso, ver: ORCE, Guillermo. Op. cit., p. 369-371.

${ }^{446}$ Id. Ibid., p. 370. 
sistema jurídico. Tendo-se em conta ser JAKOBS um autor funcionalista, sabe-se que este não reconhece a capacidade do sistema jurídico de adentrar na psique humana. Bem por isso, a consciência é inobservável por tal sistema, de forma que qualquer comunicação contrária à norma não consistirá uma manifestação desse conteúdo mental. Assim, o sistema jurídico trabalha com a reconstrução dessas manifestações exteriores, possivelmente derivadas de conteúdos mentais, para estruturas próprias, com as quais pode lidar. Nesse sentido, a autoconsciência a que faz menção JAKOBS se trata, em verdade, do reconhecimento (atribuição, portanto) pelo sistema jurídico de que o indivíduo possui uma organização psíquica capaz de atribuir responsabilidades ${ }^{447}$. Em outras palavras, o Direito reconhece, como sistema dotado de linguagem própria, a comunicação, que presume porquanto não tem acesso à pessoa humana por ser ela um sistema autônomo - a existência de uma organização psíquica do indivíduo, entendida como autoconsciência, e o ponto de convergência entre esses dois sistemas estaria na "personalidade", a qual permite que o sistema jurídico, operando com sua linguagem e suas regras, localize a responsabilidade do indivíduo, mesmo sendo incapaz de ingressar efetivamente naquela consciência.

É perceptível, então, que, no pensamento de JАKOBS, a autoconsciência não é um dado aferido ou aferível pelo sistema jurídico, posto que pertencente a seu entorno (ao sistema "pessoa humana"). Atua, em verdade, como elemento de referência para definir a personalidade e, dessa forma, atribuir-lhe ${ }^{448}$. Nesse sentido, como não há a apuração do conteúdo natural da consciência, servindo esta apenas como critério fora do sistema jurídico ao qual se refere para poder reconhecer a personalidade própria da pessoa física e, consequentemente, a capacidade de ser responsabilizada, seria possível pensar-se num critério funcionalmente equivalente para a pessoa jurídica sem que se desnature este funcionamento do sistema jurídico, já que, como se disse, para este não importará a consciência em si, tomada no aspecto de seu conteúdo ${ }^{449}$.

\footnotetext{
${ }^{447}$ Id. Ibid., p. 371-374.

${ }^{448}$ Id. Ibid., p. 375-376.

${ }^{449}$ Afirma ORCE que "[...] los contenidos "naturales" de la consciência no juegan un papel en la imputación; al ser esto así, no se entiende por qué la conciencia debería ser el único punto de encuentro que los sistemas sociales podrían tomar como referencia para construir la personalidade y realizar sus atribuiciones de responsabillidad. Si la psiquis es algo que no deja de pertenecer al entorno del sistema jurídico, no puede encontrársele una cualidad especial que la haga irreplazable para la constitución de la personalidade; la conciencia pude funcionar como punto de encuentro de las atribuiciones a la persona físicas, pero puede tener su equivalente en las personas jurídicas. La autoconciencia de las personas físicas no tiene ninguna posición privilegiada frente, por ejemplo, a las autodescripciones de la empresa que se encuentran en sus estatutos o las reglas de pertinência dentro de una persona jurídica.”. Id. Ibid., p. 376. Esta, aliás, é a construção funcionalmente equivalente a que recorre CARLOS GÓMEZ-JARA DíEZ para definir o seu conceito construtivista de culpabilidade para a pessoa jurídica, como teremos oportunidade de detalhar no item 5.1.13.
} 
Bem por isso, a crítica ao pensamento mais atual de JAKOBS permite reconhecer que a culpabilidade independe da consciência para se definir. Se a esta se apega para se determinar em relação à pessoa física, pode, contudo, adotar outro critério funcionalmente equivalente para reconhecer uma personalidade na pessoa jurídica capaz de atribuir-lhe responsabilidade penal, no sentido de admitir sua capacidade comunicativa para negar vigência à norma ${ }^{450}$.

De igual modo, a alegada ausência de identidade entre aquele que realiza o fato e o que é apenado parte da ideia de que a consciência da pessoa jurídica seria transferida de seu órgão. Se assim se entendesse, efetivamente a alteração de um representante da empresa poderia implicar em que aquele que estava presente no momento do fato fosse diferente daquele que compõe a pessoa jurídica no momento da sanção, acarretando, por conseguinte, a falta de identidade entre o ente coletivo que atua e o que sofre a pena. Mais uma vez, o problema estaria em se adotar uma responsabilidade vicária, com a errônea interpretação de que a existência jurídico-penal da pessoa jurídica dependeria das pessoas físicas que por ela atuam, no sentido de que a responsabilidade penal daquela, em verdade, representaria a transferência da responsabilidade penal que seria dos entes físicos que a compõem $^{451}$.

A bem da verdade, para se sustentar uma responsabilidade própria das pessoas jurídicas, seus órgãos devem ser reconhecidos como instrumentos, e não com ela identificados, tal como o corpo para a pessoa física funciona como instrumento para a sua atuação ${ }^{452}$ Presente essa interpretação, não haveria, portanto, a necessidade de se apurar uma atuação culpável do órgão para trasladá-la ao ente coletivo e assim reconhecer sua responsabilidade penal, o que acabaria redundando na irresponsabilidade do órgão, ponto crítico para JAKOBS. Ainda que presente, em certa medida, uma "conexão naturalística", por assim dizer, entre a ação do órgão e a pessoa jurídica (que, ao que se pensa, tende a ser

\footnotetext{
${ }^{450}$ Como bem observa ORCE: “[...] no hay ninguna razón jurídica para crer que la conciencia goza de la exclusividad para funcionar como substrato en comunicaciones acerca de la fidelidade a las normas de indetidad de una sociedade.". Id. Ibid., p. 377.

${ }^{451}$ ORCE constata: "La objeción de Jakobs, sin embargo, nace exclusivamente del error de identificar la conciencia, mediante una regla de imputación, a la persona jurídica: en un esquema tal de pensiamiento, evidentemente el cambio del órgano trae consecuencias para la aplicación de la pena a la persona jurídica.". Id. Ibid., p. 381.

${ }^{452}$ Sobre isso, interessante o exemplo trazido por ORCE: "Tras la caída de un reloj empujado por una mano entran en juego reglas de adscripción: la caída y la rotura del reloj pertenencen a la persona si ésta pudo haberlo evitado - por nombrar una regla cualquiera - y no lo hizo; y no pertenece a la persona si no pudo ser evitado (por ejemplo, si existió un acto reflejo que no pudo haberse antecipado, etc.). Sin embargo, esta descripción no necessita, para ser completa, decir que en uno y outro caso, en primer lugar, la "mano fue responsable", y que luego hubiera que determinar en qué casos lo fue también la persona, y ello, además, mediante qué regla de imputación.”. Id. Ibid., p. 382-383.
} 
cada vez mais diluída com o aumento da complexidade estrutural das empresas), a valoração relacionada à responsabilização penal desta última deve ser dotada de autonomia.

Assim, a partir da crítica da interpretação de JAKOBS, pode-se dizer que a admissão dessa inexistência de identidade entre órgão e pessoa jurídica permite assumir que o reconhecimento da culpabilidade da pessoa jurídica não implica na transferência da culpabilidade da pessoa física que a compõe e consequente exoneração da culpabilidade (e responsabilidade) desta última.

Dessa forma, é impossível negar a contribuição de JAKOBS ao trazer à baila a falta de autoconsciência e de identidade entre agente e sancionado como argumentos para se negar a responsabilidade penal da pessoa jurídica, na medida em que, com isso, evidenciou a necessidade de se alcançar formulações teóricas que reconhecem a autonomia da pessoa jurídica em relação aos seus órgãos, bem como uma culpabilidade da pessoa jurídica independente do conceito de consciência.

De outro lado, JAKOBS, constatando a complexidade da sociedade, que redunda em seu desenvolvimento fundamentalmente por contatos anônimos, ressalta que esta apenas pode ter como máxima fundamental não a "proteção ótima de bens jurídicos", mas sim a "administração ótima da própria organização"453. Ora, a valorização do aspecto organizacional e de seu papel na sociedade (ainda que tal reconhecimento, ao que se pense, não precise implicar no necessário abandono do bem jurídico como critério reitor do Direito, dependendo, em verdade, da posição filosófica, ou método que se adotar ${ }^{454}$ )

\footnotetext{
${ }^{453}$ Afirma JAKOBS: "Una sociedad altamente compleja que se desenvuelve preferentemente a través de contactos anónimos no conoce como máxima fundamental la "protección óptima de bienes jurídicos" sino la “administración óptima de la propia organización”. JAKOBS, Günther. La culpabilidad de los foráneos. In: CANCIO MELIÁ, Manuel, FEIJOO SÁNCHEZ, Bernardo (ed.). Teoría funcional de la pena y culpabilidad. Pamplona: Aranzadi, 2008, p. 119-120.

${ }^{454}$ Faz-se esse adendo para ressaltar que a importância da busca pela "otimização organizativa" no reconhecimento da necessidade de uma responsabilidade das pessoas jurídicas foi por nós pinçada do pensamento de JAKOBS sem a adoção de qualquer posicionamento filosófico ou metodológico. Ou seja, tal reconhecimento tem uma importância autônoma, independente da filosofia ou metodologia que se empregar para reconhecer a responsabilidade da pessoa jurídica. E diz-se "filosofia" ou "metodologia" porque há na doutrina quem afirme que é necessário discutir o "método" a ser empregado na responsabilidade penal da pessoa jurídica, muito mais do que a opção por certa escola penal e, portanto, o apego à certa postura filosófica. Nesse sentido, RUIZ RENGIFO defende que a responsabilidade penal da pessoa jurídica é uma necessidade social, obedecendo, portanto, a critérios sociais, e não filosóficos. Assim, salienta que deve haver a preocupação por uma opção metodológica adequada, que para ele deve ser o método pragmático. Afirma o aludido autor: "Hasta ahora podemos señalar que el método funcional radical o el moderado no satisfacen las exigencias "posibles" dogmáticas de una responsabilidad penal de las personas jurídicas. Mas allá de un sistema funcional. Un nuevo fundamento del derecho penal basado em el sentido común. Más hipermoderno que postmoderno. Todas las teorizaciones o escuelas penales se fundamentan en una o cual postura filosófica. Qué hacer con esta tendência, si la filosofía ha muerto. Ya no ocupa el papel central. Razón: poco pragmática. No así, en Estados Unidos de Norteamértica, que desde los años veinte (20) reconocen que la Corporación
} 
parece-nos o cerne para se entender a importância da responsabilização da pessoa jurídica e as peculiaridades que a envolvem. Antes mesmo de se definir o instrumento jurídico a ser utilizado nessa forma de responsabilização (se penal ou não), certo é que, qualquer opção que se faça terá que ter em conta uma específica forma de atuação do direito neste âmbito, que, em face da complexidade dos entes coletivos, não terá competência (no sentido de conhecimento técnico) muito menos interesse (no sentido dos custos que se impõe) para efetuar uma regulação direta. Assim, acaba por se valer de uma "autorregulação regulada", buscando o alcance dessa otimização organizativa por meios próprios das empresas, cabendo ao Direito apenas o delineamento de diretrizes para a definição do âmbito desta autorregulação e os meios de sancionamento pela sua não implementação.

Evidente, então, que a dimensão organizativa ressaltada por JAKOBS constitui o cerne dos fundamentos dogmáticos mais recentes relacionados à responsabilização da pessoa jurídica, contribuindo o autor, ao que se pensa, também neste aspecto para o tema ${ }^{455}$, conquanto sua interpretação não vá no mesmo sentido.

\subsubsection{O conceito construtivista de culpabilidade de CARLOS GómEZ-JARA DíEz: a culpabilidade da pessoa jurídica por sua cultura empresarial de descumprimento da legalidade.}

A busca por um conceito de culpabilidade do ente coletivo que não se construa de forma apartada ao da pessoa física e, consequentemente, a possibilidade de se reconhecer causas de exculpação ou de atenuação à responsabilidade penal próprias desse ente parecem ter conduzido a busca por este novo conceito de culpabilidade empresarial ${ }^{456}$.

Inicialmente, deve-se ressaltar que GóMEZ-JARA DíEZ busca fundamentar uma responsabilidade penal das "empresas", dos entes coletivos tomados em sua concepção

delinque. Una visión pragmática anticipada marcada en la actualidad mayormente por la globalización. La responsabilidad penal propia de las personas jurídicas es hija de la globalización. Van de la mano. Obsérvese que el castigo penal de las empresas deviene de raziones de la sociología, o como dice Tiedemann "una necesidad social". Su existência obedece a criterios sociales no filosóficos. Es la gran diferencia del enfoque a esta cuestión. Todo en cuanto desde la perspectiva filosófica resulta apretado romper el dogma societas delinquere non potest.". RUIZ RENGIFO, Hoover Wadith. La responsabilidad penal de las personas jurídicas. Una tarea inconclusa en España y Colombia. Salamanca: Ratio Legis, 2012, p. 23-26.

${ }^{455}$ Nesse sentido, SILVINA BACIGALUPO constata que “... Jakobs ha sido el primer autor que ha propuesto un modelo nuevo de la teoria del delito en donde el concepto de acción y de culpabilidad adquieren fundamentaciones nuevas que pueden servir al replantamiento del objeto de la presente investigación.". BACIGALUPO, Silvina. La responsabilidad penal..., p. 148.

${ }^{456}$ Sobre isso, ver: GÓMEZ-JARA DÍEZ, Carlos. La culpabilidad de..., p. 167. 
material, não se apegando a uma conceituação formal de pessoa jurídica ${ }^{457}$. Traz, assim, uma visão mais ampla do espectro de aplicação dessa responsabilidade penal.

No que concerne ao específico aspecto de sua construção teórica de culpabilidade, esclarece que não pretende a busca de um conceito análogo à culpabilidade individual, mas de uma concepção funcionalmente equivalente e que, portanto, esteja fundada na autorresponsabilidade empresarial, não se remetendo a aspectos derivados das pessoas físicas componentes da estrutura da empresa, muito menos a fatos de conexão ${ }^{458}$.

A sua construção teórica procura responder algumas objeções levantadas às já formuladas concepções de culpabilidade empresarial, ressaltando-se, nesse aspecto, a tentativa de fundamentar materialmente essa culpabilidade (e a consequente responsabilidade penal), demonstrando, com isso, que a atribuiçao de responsabilidade penal à pessoa jurídica não terá como consequência necessária a exclusão da responsabilidade penal da pessoa física (uma vez que terão fundamentos autônomos) ${ }^{459}$, bem como que sua concepção de culpabilidade admite causas de exclusão.

Para GóMEZ-JARA DíEZ a solução para os questionamentos levantados a uma concepção de culpabilidade própria da pessoa jurídica reside justamente na escolha do pressuposto metodológico teórico que se empregará. Entende, portanto, que a superação das objeções aventadas só poderá ser alcançada construindo-se a culpabilidade a partir da teoria dos sistemas sociais autopoiéticos (denominada, também, como construtivismo operativo, de onde advém a nomenclatura adotada para essa concepção de culpabilidade).

Reconhece o autor que, tal como o Direito e os indivíduos, a empresa constitui um sistema autopoiético, mas social (aproximando-se, nesse aspecto, do Direito, e distanciando-se dos indivíduos, que são classificados como sistemas autopoiéticos psíquicos), na medida em que é um sistema organizativo que se compõe e se reproduz por suas próprias decisões ${ }^{460}$. A reprodução continuada dessas suas decisões permite que a empresa constitua sua própria realidade, desenvolvendo um conhecimento organizativo e uma capacidade de aprendizagem que a torna uma realidade independente do entorno

\footnotetext{
${ }^{457}$ Cf. PASTOR MUÑOZ, Nuriá, ¿Organizaciones culpables?..., p.2.

${ }^{458}$ É nesta aspiração, por exemplo, que se vê distanciar da construção teórica de BACIGALUPO SAGGESE que, conquanto também parta da teoría dos sistemas sociais autopoiéticos, fundamenta a responsabilidade empresarial na atuação das pessoas físicas e na apuração do fato de conexão, permanecendo, na visão de GÓMEZ-JARA DíEZ, no campo da heterorresponsabilidade. Sobre isso, ver: GÓMEZ-JARA DÍEZ, Carlos. La culpabilidad penal ..., p. 212. PASTOR MUÑOZ, Nuria. ¿Organizaciones culpables?..., p.8.

${ }^{459}$ Neste aspecto, busca enfrentar acrítica formulada por JAKOBS no sentido de que a responsabilizaçao penal empresarial deveria onducir à impossibilidade de castigar às pessoas físicas responsáveis. Cf. JAKOBS, Günther, Punibilidad de las personas jurídicas. In: El funcionalismo en derecho penal. Libro homenaje al profesor Günther Jakobs. v. I. Bogotá: Universidad Externado de Colombia, 2003, p. 337-338.

${ }^{460}$ GÓMEZ-JARA DÍEZ, Carlos. La culpabilidad penal..., p. 203.
} 
social e humano, os quais não têm a capacidade de acessar-lhe, (incapacidade essa mútua, aliás, como característica da própria relação entre os sistemas autopoiéticos), mas apenas de construir-lhe uma imagem, dentro de sua linguagem.

Desse singelo panorama da complexa teoria dos sistemas sociais autopoiéticos, o que nos importa é questionar como esse paradigma teórico é aplicado ao Direito (ou seja, à responsabilidade penal da empresa). Para tanto, GómEz-JARA DíEz faz uso do "normativismo funcionalista" de JAKOBS, reformulando o conceito de culpabilidade funcional-pessoal para um conceito de culpabilidade construtivista. Tal como JAKOBS, sua formulação de culpabilidade continua fundada na ideia de questionamento da vigência da norma. Inova, contudo, ao perceber a pessoa jurídica como ator capaz de efetuar tal questionamento $^{461}$.

Para tal reconhecimento, o autor desenvolve um conceito de pessoa jurídicopenal diverso, que abrange tanto pessoas físicas como jurídicas. Entende GóMEZ-JARA DíEZ que, tal como a capacidade de ação, a capacidade de organização (seu equivalente funcional para as empresas) ${ }^{462}$ significa que as empresas estão dotadas de liberdade (a já mencionada competência organizativa) e, como tal, podem respeitar a norma ou questionar sua vigência. Tais características vão permitir reconhecer à empresa uma cidadania peculiar, uma cidadania corporativa.

Tal concepção parte, a bem da verdade, de uma reformulação da própria ideia de "pessoa jurídico-penal", que desenvolve como conceito único, capaz de abarcar tanto as pessoas físicas com as pessoas jurídicas. Nessa esteira, volta seus olhares para um conceito mais amplo, capaz de definir a personalidade para entes tão distintos, qual seja, a "autoreflexão". Diga-se mais amplo porque o conceito de "autoreflexão" é capaz de abranger não só a capacidade de consciência das pessoas físicas, concepção central e única no individualismo metodológico, como também a capacidade de auto-organização das pessoas jurídicas.

Assim, no que concerne a esta capacidade de auto-organização do ente coletivo, como expressão de sua autoreflexividade, em primeiro lugar, reconhece-se uma

\footnotetext{
${ }^{461}$ É interessante a contradição havida nesse pressuposto teórico. É que JAKOBS, com seu normativismo funcionalista, vai justamente negar a responsabilidade penal da pessoa jurídica em seus escritos mais recentes, enquanto GÓMEZ-JARA DíEZ usa tal conceito como um dos elementos teóricos para a construção de sua responsabilidade penal empresarial. Há, aqui, a aplicação teórica do contributo de JAKOBS à responsabilidade penal da pessoa jurídica, como tivemos oportunidade de analisar no item anterior (5.1.12).

${ }_{462}$ Nesse aspecto, toma por base a concepçao de HeINE, para quem o "dominio da organizaçao funcional sistémico pela empresa é equivalente ao dominio do fato próprio do Direito Penal individual" e de BOTKE, que reconhece a competência da empresa sobre a organizaçao de uma série de contatos sociais. Sobre isso, ver: PASTOR MUÑOZ, Nuria. ¿Organizaciones culpables?..., p. 9.
} 
função peculiar da empresa de controlar e gerir os riscos advindos de sua atuação diante da incapacidade do Estado para atuar em tais âmbitos específicos. Neste aspecto, diante da complexidade da estrutura empresarial, a regulação estatal apenas se dirigirá a um "controle de contexto" $" 463$.

A obrigação imposta às organizações empresariais, então, será no sentido de se fidelizarem ao Direito, o que se dá pelo desenvolvimento de uma cultura empresarial voltada a tanto. Para isso, devem não somente fomentar uma filosofia empresarial de cumprimento do direito, como também desenvolver uma estrutura organizativa capaz de garantir este direcionamento conforme ao direito.

É, portanto, a partir do reconhecimento de que à empresa cabe o dever de institucionalização de uma cultura de fidelidade ao direito (tal como o indivíduo) que se permite dotá-la de uma cidadania, peculiar, é bem verdade, porquanto adjetivada como corporativa.

Bem por isso, a quebra do papel de cidadão fiel ao direito, ou seja, a não institucionalização de uma cultura empresarial de fidelidade ao direito é que constituirá a manifestação da culpabilidade jurídico-penal empresarial ${ }^{464}$.

De outro lado, é pelo reconhecimento da liberdade de autorregulação empresarial que permite imputar a responsabilidade pelas consequências da atuação da pessoa jurídica. Assim como ao indivíduo, à empresa é reconhecida uma condição de liberdade que possui como face oposta ao dever de, atuando dentro desta liberdade, manter-se nos limites do risco permitido. É perceptível, então, que o reconhecimento de uma cidadania corporativa permite retirar a empresa da mera lógica de custos e benefícios para uma orientação pautada pelo binômio direitos e deveres ${ }^{465}$.

Os fundamentos materiais dessa culpabilidade empresarial estariam apoiados, portanto, em três aspectos: a fidelidade ao direito como condição de vigência da norma, a igualdade objetivada entre as pessoas e a possibilidade de questionar a vigência da norma mediante um procedimento conforme ao direito.

A fidelidade ao direito, como já se disse, está ligada ao reconhecimento da cidadania da pessoa jurídica, derivada da doutrina americana do "good corporate citizen". Neste aspecto, evidencia-se a proximidade dos programas de compliance com a definição da culpabilidade empresarial, na medida em que o cumprimento do papel de bom cidadão

\footnotetext{
${ }^{463}$ GÓMEZ-JARA DÍEZ, Carlos. La culpabilidad de..., p. 168-169.

${ }^{464}$ Id. Ibid., p. 169.

${ }^{465}$ Id. Ibid., p. 170.
} 
corporativo demandaria a adoção de diversos aspectos deste programa (como a autorregulação, a criação de mecanismo para controle de atividades, bem como o dimensionamento e gestão de riscos, entre outros aspectos), programa este que serviria como "indicador da cultura corporativa de fidelidade ao direito", ou seja, meio de determinação da culpabilidade corporativa ${ }^{466}$.

Neste aspecto, também, sobressai o reconhecimento das empresas como unidades autônomas de organização, produtoras de risco e conhecimento. Bem por isso, não poderia mais o Direito pretender utilizar-se da regulação tradicional para controlar diretamente as empresas. Caberá a ele um novo papel, diante desta nova realidade, que é, reconhecendo a capacidade de autorregulação das empresas (ou seja, sua capacidade de gerar sua própria fidelidade ao Direito, na interpretação de GóMEZ-JARA DíEZ ${ }^{467}$ ), apenas "regular essa autorregulação", ou seja, "regular o contexto em que as empresas se fidelizam ao Direito por meio dessa autorregulação"468.

De outro lado, a igualdade objetivada entre as pessoas consiste em se fundar um conceito de culpabilidade na construção objetivada de pessoa dada pelo sistema social, e não no indivíduo, padronizando-se, ainda, neste sistema, o dever de fidelidade ao Direito $^{469}$.

Por fim, para que se possa reconhecer à pessoa, física ou jurídica (ente coletivo), a culpabilidade, é necessário que ela esteja dotada da possibilidade de questionamento da vigência da norma por meio de um procedimento em conformidade com o Direito. Em outras palavras, apenas se pode configurar a culpabilidade em face do questionamento da vigência da norma se ao mesmo agente era possível a utilização de meios em conformidade ao direito para efetuar o questionamento normativo. Assim, apenas em uma democracia deliberativa e jurídico-estatal a pena e a culpabilidade seriam admissíveis $^{470}$.

Este meio adequado ao direito para o questionamento normativo é reconhecido à pessoa jurídica como sua "possibilidade de participação da produção comum de sentidos", ou seja, sua "competência para intervir em assuntos públicos",471, que estaria

\footnotetext{
${ }^{466}$ GÓMEZ-JARA DÍEZ, Carlos. La culpabilidad penal..., p. 235-258.

${ }^{467}$ Id. Ibid., p. 270

${ }^{468}$ Ver: PASTOR MUÑOZ, Nuria. ¿Organizaciones culpables?..., p. 11

${ }^{469}$ Id. Ibid., p. 11 e GÓMEZ-JARA DÍEZ, Carlos. La culpabilidad penal..., p. 276

${ }^{470}$ Nesse sentido, GóMEZ-JARA DíEZ faz uso dos conceitos de KINDHAÜSER e GÜNTHER. Cf. PASTOR MUÑOZ, Nuria ¿Organizaciones culpables?..., p. 12. Também: GÓMEZ-JARA DÍEZ, Carlos. La culpabilidad penal..., p. 286.

${ }^{471}$ GÓMEZ-JARA DÍEZ, Carlos. La culpabilidad de..., p. 170.
} 
fundada na participação no debate democrático (ainda que não por meio do voto, mas sim pelo discurso público), influenciando a criação e definição das normas sociais ${ }^{472}$. Ora, a concretização tupiniquim desta competência dos entes coletivos talvez possa ser bem apontada na influência dos lobbys sobre a produção legislativa, que, ao que parece, tem expressado maior poder de conformar a norma do que os votos individuais e, se não efetuado por meios escusos.

Em suma, é importante salientar que, neste complexo modelo construído por GÓMEZ-JARA o defeito de organização não consistirá no fundamento da culpabilidade empresarial. A bem da verdade, o defeito de organização constituirá o injusto da pessoa jurídica, cuja responsabilização dependerá, ainda, da verificação da culpabilidade, traduzida como ausência de ética empresarial ou de uma cultura de cumprimento da legalidade ${ }^{473}$, tentado, com isso, solucionar a confusão entre injusto e culpabilidade

\subsubsection{A busca de um modelo próprio de culpabilidade empresarial por ADAN NIETO MARTín.}

Antes mesmo de adentrar no conceito de culpabilidade formulado por NIETO MARTín, faz-se necessário trazer a lume suas relevantes considerações metodológicas que, ao que se pensa, são essenciais a um adequado entendimento de sua construção teórica de culpabilidade da pessoa jurídica.

Em primeiro lugar, é importante ter em mente que sua escolha por fundamentar uma responsabilidade penal das pessoas jurídicas lastreada numa culpabilidade própria desses entes coletivos não deriva de uma busca por um modelo de imputação adequado constitucionalmente. Para ele, não há qualquer oposição entre a opção pelo modelo vicarial (em que a responsabilidade penal da pessoa jurídica será objetiva) e o princípio da culpabilidade. Chega a essa conclusão constatando, em primeiro lugar, que o princípio da culpabilidade derivaria, na Constituição espanhola, da dignidade da pessoa e do livre desenvolvimento da personalidade, estritamente ligados, portanto, à pessoa humana. Assim, inexistiria óbice constitucional a uma responsabilidade penal das empresas sem qualquer apuração de culpabilidade própria destas ${ }^{474}$.

Diante desta conclusão, NiETO MARTín remete o discurso para outro patamar.

\footnotetext{
${ }^{472}$ Id. Ibid., p. 171.

${ }^{473}$ Sobre isso, ver: FEIJOO SÁNCHEZ, Bernardo José. La persona jurídica..., p. 81 e ss.

${ }^{474}$ NIETO MARTÍN, Adan. La responsabilidad penal..., p. 117-120.
} 
Afirma que o debate legislativo sobre o modelo de imputação a ser adotado deve centrar-se não em questões de constitucionalidade, mas em indagações de índole prática, no sentido de se apurar se a adoção de um modelo de vicarious liability é eficaz e teoricamente consistente $^{475}$.

Neste sentido, vai apontar quatro disfunções, de caráter político-criminal, do modelo de responsabilidade por transferência. Em primeiro lugar, ressalta que a responsabilidade penal da pessoa jurídica apoiada num modelo de vicarious liability não consegue superar os problemas atinentes à dificuldade de se identificar um autor pessoa física culpável, sobretudo nos modelos mais estritos da teoria da identificação, que não se contentam com a apuração de uma falta de vigilância empresarial como fato de conexão ${ }^{476}$.

Em segundo lugar, ao delimitar a responsabilidade empresarial aos atos produzidos pelos superiores, acaba não transferindo ao ente coletivo todos os custos que derivam de sua atividade ${ }^{477}$.

De outro lado, e na mesma linha de raciocínio, esta forma de responsabilização acaba incentivando a busca de responsáveis fictícios (bodes expiatórios) nos níveis hierárquicos inferiores ${ }^{478}$.

Por fim, é indubitável que neste modelo há um privilégio para as empresas de maior tamanho e complexidade, em que as dificuldades para se apontar um responsável nas esferas hierárquicas superiores acaba sendo muito maior do que em empresas de menor porte $^{479}$.

Diante de tais constatações, NIETO MARTín buscará desenvolver um modelo próprio de culpabilidade empresarial. Para tanto, parte da análise de quatro propostas doutrinárias que vão lhe guarnecer de elementos para a estruturação de seu próprio modelo. Assim, lança seus olhos sobre as construções teóricas de HEINE, LAMPE, FISSE e BRAITHWAITE e GÓMEZ-JARA DIEZ.

Após efetuar uma digressão sobre cada uma de tais formulações, chega à conclusão de que um dos problemas essenciais na determinação de uma culpabilidade empresarial é a não distinção das questões que se pretende enfrentar, tratando-as de igual forma, mediante uma resposta teórica única que, por isso mesmo, acaba sendo inadequada. Melhor esclarecendo, os problemas que se tratam de forma idêntica, conquanto

\footnotetext{
${ }^{475}$ Id. Ibid., p. 120.

${ }^{476}$ Id. Ibid., p. 120.

${ }^{477}$ Id. Ibid., p. 121.

${ }^{478}$ Id. Ibid., p. 121

${ }^{479}$ Id. Ibid., p. 121
} 
completamente diversos, remetem à "discussão europeia" de uma culpabilidade da empresa ainda referida ao "se" da responsabilidade e, ao "debate norteamericano" relacionado aos modelos de imputação e à intensidade da responsabilidade ${ }^{480}$.

Bem por isso, propõe o autor a distinçao de dois níveis de discussão. O primeiro, básico, consiste em determinar quais são os fundamentos de uma culpabilidade da empresa; já o segundo pretende analisar questões de caráter mais concreto, como a possível distinção entre uma responsabilidad penal empresarial dolosa e outra imprudente; a imputabilidade; bem como a relação entre a culpabilidade empresarial e das pessoas físicas que a integram.

Feita essa necessária distinção, deve-se esclarecer que o que nos importará é a determinação da culpabilidade da empresa, com seu respectivo conteúdo material.

Verificando a existência de quatro variantes da culpabilidade empresarial ${ }^{481}$, NIETO MARTín constata que a formulação mais adequada é a que se baseia no defeito de organização. Contudo, não descarta de todo as demais formulações, ressaltando que elas apontarão aspectos que servirão para concretizar o conteúdo do defeito de organização ${ }^{482}$.

Ressalta o autor que a responsabilidade da empresa derivará do fato de não ter gerado um sistema destinado a prevenir de forma razoável os riscos derivados da atividade empresarial. Nesse sentido, estabelece uma distinção entre os tipos de riscos, que para ele podem se expressar de duas formas: a) riscos diretos aos bens jurídicos (coletivos ou individuais), ainda que não se constate um comportamento delitivo individual reprovável, e, b) riscos derivados de condutas delitivas dolosas ou imprudentes de componentes da

\footnotetext{
${ }^{480}$ Afirma o autor: "Uno de los problemas fundamentales a la hora de enjuiciar la culpabilidad de empresa es que en realidad los autores utilizan sus construcciones para resolver problemas distintos. En la discusión europea la culpabilidad de la empresa tiene que ver aún com el si de la responsabilidad, mientras que en la norteamericana el debate tiene que ver sobre todo com los modelos de imputación o la intensidad de la responsabilidad. Convendría, pues, distinguir dos niveles de discusión distintos: uno básico, que consistiria en determinar cuáles son los presupuestos mínimos, los fundamentos, para que pueda hablar de culpabidlaid de empresa, y un segundo nível posterior dedicado a resolver cuestiones más concretas como si existe la un responsabilidad de empresa dolosa y otra imprudente, la existencia de organizaciones imputables e inimputables o la relación entre la culpabilidad de la empresa y la de las personas físicas que la integran.”. Id. Ibid., p. 145.

${ }^{481}$ Interessante constatar que a distinção de quatro variantes de culpabilidade da empresa não coincide com a diferenciação entre as quatro propostas doutrinárias analisadas por NIETO MARTíN. Isto porque, na interpretação por ele efetuada, é possível que um mesmo autor alcance mais de um conceito de culpabilidade distinto, ainda que partindo de um mesmo fundamento teórico. Assim, estas quatro variantes seriam: a) a culpabilidade da empresa como cultura corporativa desviada (presente no Código Penal australiano e na formulação de GÓMEZ-JARA DíEZ); b) a culpabilidade da empresa como defeito de organização (presente na legislação britânica e nas teorias de HEINE e GÓMEZ-JARA DíEZ); c) a culpabilidade da empresa como ausência de um comportamento pós-delitivo adequado (conceito de reactive fault de FISSE e BRAITHWAITE); e, d) a culpabilidade da empresa como culpabilidade pelo caráter ou culpabilidade pela condução da empresa (presente nas propostas de HEINE e LAMPE). Id. Ibid., p. 145-146)

${ }^{482}$ Id. Ibid., p. 146.
} 
estrutura empresarial.

É interessante notar que, na sua formulação de culpabilidade da pessoa jurídica, NIETO MARTín sempre vai buscar conectar sua construção teórica com os fins de política criminal que orientam e justificam a admissão da responsabilidade penal da pessoa jurídica, revelando, assim, não só uma preocupação metodológica, mas prática também. Nesse sentido, então, assevera que a fixação da culpabilidade da empresa como defeito de organização, traduzido na não criação de um sistema preventivo para evitar riscos, consagra a busca por uma autorregulação, evitando a excessiva utilização do direito penal

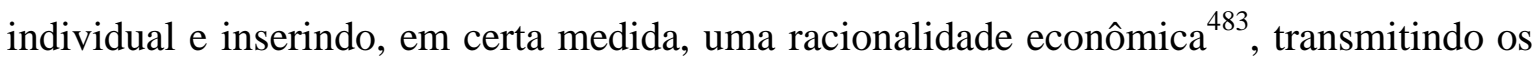
custos da prevenção dos fatos delitivos do Estado para as empresas, que assumem “deveres" compatíveis com suas posições predominantes nas relações sociais.

Observa o autor, então, que a culpabilidade traduzida num déficit de autorregulação não revela uma "linha de política legislativa tipicamente penal", mas consagra considerações do direito como direito reflexivo, indicando, também nesse âmbito, a adoção de uma estratégia legislativa cada vez mais importante em áreas como o direito ambiental, administrativo, de sociedades etc. Conclui, assim, que a responsabilidade penal da pessoa jurídica se trata da ultima ratio da autorregulação regulada ${ }^{484}$.

A opção por um modelo de culpabilidade da empresa, segundo ADAN NIETO MARTín, teria esteio, também, na vantagem comparativa em relação ao modelo vicarial, tendo-se em conta a determinação de deveres de auto-organização a esses entes coletivos. Isto porque, num modelo vicarial, em que há identificação da culpabilidade individual com a responsabilidade do ente coletivo, não há nenhuma possibilidade de se distanciar esses dois aspectos, de forma que se acaba impondo um dever de auto-organização máximo, de sempre evitar a prática delitiva pelo autor individual no bojo empresarial, restringindo-se

\footnotetext{
${ }^{483}$ Nesse sentido, afirma NIETO MARTín que "La autoorganización, concretada de este modo, evita la sobreexplotación del derecho penal individual, contribuye a abaratar los costes de processo penal y a que las empresas asuman entre sus costes la evitación de hechos delitivos, pues obviamente las medidas de organización tienen un valor económico que incide sobre la producción, y permite ahorrar costes públicos en el esclarecimento de delitos.". Id. Ibid., p. 146-147.

${ }^{484}$ Ressalta NIETO MARTÍN: "La culpabilidad de la empresa y su responsabilidad representa por ello el sistema de cierre del conjunto de demandas de autoorganización que se le formulan desde âmbitos muy diversos del sistema jurídico. En efecto, si muchas de estas normas, parcialmente consideradas, implican ya deberes de autoorganización que sin lugar a dudas inciden en la evitación de comportamientos individuales defectuosos, la culpabilidad penal por defecto de autoorganización completa estas obligaciones extendiéndolas a todos aquellos bienes jurídicos en los que el legislador considere conveniente implantar la responsabilidade penal colectiva. La responsabilidade penal de las personas jurídicas es, pues, la ultima ratio de lo que hemos denominado autorregulación coaccionada o autorregulación regulada y concreta el deber de las empresas de colaborar con el Estado con el fin de assegurar la eficacia del derecho, redistribuyendo de alguna manera los costes que conlleva la persecución y el ejuiciamiento de comportamentos delictivos.”. Id. Ibid., p. 147.
} 
excessivamente a liberdade da empresa. Já num modelo de culpabilidade empresarial, a responsabilidade do ente coletivo é afastada, ainda que constatada uma prática delitiva individual em seu bojo, se há a implementação de medidas razoáveis de controle preventivo. Vê-se, assim, que o espectro de atuação da empresa acaba sendo mais alargado, com maior liberdade na determinação de sua organização, que deve buscar a diminuição razoável, proporcional, dos riscos delitivos em sua atividade, e não sua completa inexistência $^{485}$. Tal constatação demonstra a preocupação de que um discurso de responsabilidade penal seja adequado à realidade em que pretende se imiscuir. Nesse sentido, não poderia a intervenção penal no âmbito empresarial, ainda que na busca por uma autorregulação, engessar a própria atividade econômica ${ }^{486}$.

A concretização do conceito de culpabilidade empresarial de NIETO MARTín, como já se disse, vai se perfazendo por meio da congregação de diversos aspectos derivados dos modelos dogmáticos de culpabilidade empresarial que submeteu a seu crivo e que, para ele, ainda que não possam ser albergados em sua plenitude, tem o mérito de enriquecer o debate, concedendo elementos para se alcançar o conteúdo material dessa culpabilidade. Nesse sentido, entende o autor que a ética empresarial deve ser compreendida, no delineamento da responsabilidade penal da empresa, não no aspecto negativo, de se demonstrar que sua ausência incitou ou influiu no comportamento delitivo no bojo do ente coletivo. A valoração dessa ética, em verdade, deve se pautar pela constatação da ausência de esforços, por parte da empresa, para implantar uma cultura de respeito à legalidade, evidenciando, assim, um defeito de organização ${ }^{487}$.

Não descarta, ademais, a ideia de culpabilidade reativa, que para ele é servível à compreensão da dimensão temporal da culpabilidade empresarial em relação à individual. Isto porque, para a apuração da culpabilidade da empresa importará tanto o aspecto proativo como o reativo, enquanto na culpabilidade individual não tem relevância o comportamento pós-delitivo para sua determinação ${ }^{488}$. Aliás, a essa conclusão também contribuiriam as formulações de culpabilidade da empresa fundadas num paralelismo com o direito penal do autor. Mais uma vez, afirma NIETO MARTín que não há qualquer inconstitucionalidade numa formulação de direito penal do autor voltada para a

\footnotetext{
${ }^{485}$ Id. Ibid., p. 148-149.

${ }^{486}$ Como ressalta o autor: "La función del legislador y después, sobre todo, de la política judicial a la hora de concretar las exigências de autorganización es ciertamiente no sobrecargar a las empresas, exigiéndoles sistemas de prevención de hechos delictivos excessivamente costosos.”. Id. Ibid., p. 148.

${ }^{487}$ Id. Ibid., p. 149-150. Apesar dessa distinção, parece-nos, contudo, que em ambos os casos o critério da ética revelou-se como negativo.

${ }^{488}$ Id. Ibid., p. 150.
} 
responsabilidade penal empresarial, na medida em que as críticas que se fazem a essa construção estariam fundadas na sua incompatibilidade com a ideia de livre desenvolvimento da personalidade, cuja proteção está adstrita à pessoa humana ${ }^{489}$. Assim, não havendo qualquer inadequação na aplicação de tal concepção à pessoa jurídica, podese dizer que a descrição de uma culpabilidade da empresa como direito penal do autor se traduz na consideração de comportamentos pré-delitivos e pós-delitivos, comportamentos esses que se manifestam de forma não pontual, revelando um déficit de autorregulação permanente, sendo o comportamento delitivo pontual uma evidência da existência permanente do defeito organizativo ${ }^{490}$.

Essa preocupação com a dimensão temporal da culpabilidade empresarial demonstra, a bem da verdade, a busca por fins garantistas e limitadores da intervenção penal, na medida em que não bastará a prática delitiva para o sancionamento da empresa, mas a demonstração de que tal delito deriva de uma falta de organização não pontual, mas estável $^{491}$. Nesse aspecto, observa-se a conexão com o próprio fim da pena, qual seja, a motivação à autorregulação. Se a prática delitiva derivasse de um defeito pontual, isolado, não decorrente de um defeito organizativo permanente, não haveria porque se cobrar da empresa determinada auto-organização, quando não foi dela que derivou o delito e, portanto, em nada poderia contribuir ao seu não cometimento, quer por considerações prédelitivas, quer pós-delitivas (evitando novas práticas).

Outro ponto importante nesse aspecto temporal é a dispensa, no âmbito da responsabilidade penal empresarial, da coincidência entre o momento do fato e a existência de uma capacidade de culpabilidade. A ideia de auto-organização empresarial não é uma constatação pontual, à época da prática delitiva, mas o desenvolvimento de um conhecimento técnico que proporcione a capacidade de adaptação a novos riscos, de forma que a empresa não poderá se eximir de sua responsabilidade sob a alegação de que à época do fato não tinha condições de previni-10 ${ }^{492}$. Deve-se ter em mente, contudo, que não basta à empresa o desenvolvimento de medidas de segurança adequadas à evitação do fato típico, mas também um comportamento pós-delitivo apropriado, reestruturando-se em conformidade com o ordenamento, o que pode servir para atenuar ou até excluir a culpabilidade, na visão de NIETO MARTín ${ }^{493}$.

\footnotetext{
${ }^{489}$ Id. Ibid., p. 151.

${ }^{490}$ Id. Ibid., p. 152.

${ }^{491}$ Id. Ibid., p. 152.

${ }^{492}$ Id. Ibid., p. 153.

${ }^{493}$ Id. Ibid., p. 154.
} 
Presente todas essas considerações, chega o autor a uma proposta de modelo legislativo a ser adotado, no qual consagra sua concepção de culpabilidade empresarial, entendida como "déficit de autorregulação permanente" ${ }^{494}$. A culpabilidade de organização se traduziria, então, na não adoção ou adoção deficiente de um Código de prevenção capaz de prevenir ou investigar a classe de delito que se realizou (ou pode se realizar) no bojo empresarial $^{495}$.

Nesse sentido, o comportamento individual converte-se numa condição objetiva de punibilidade, na medida em que a mera existência do defeito de organização, sem a realização de um fato delitivo, torna inviável a aplicação de sanção penal.

Aponta NIETO MARTín, ademais, que identificar a origem da conduta danosa na hierarquia da estrutura empresarial (o que não significa a necessária de identificação do autor ou autores - pessoas naturais - do delito) terá importância para avaliar a gravidade do defeito de organização, devendo refletir na regulação das circunstâncias agravantes e na eleição da sanção a se impor ${ }^{496}$. Dá importância, também, ao tamanho da pessoa jurídica, para definir ser inimputável aquelas que possuam menos de 50 funcionários ${ }^{497}$, observando, ainda, que as empresas que são constituídas apenas com a finalidade de prática delitiva também não serão responsabilizadas, devendo haver a desconsideração da personalidade jurídica com a aplicação de sanções aos responsáveis individuais ${ }^{498}$.

Quanto ao papel dos Códigos de prevenção (programas de compliance), afirma que sevirão de parâmetro a ser observado pelo julgador no momento de avaliar a eficácia das medidas de organização empresarial. Assim, tais códigos darão concretude à noção de culpabilidade empresarial fundada na ideia de auto-organização voltada para a prevenção e o descobrimento de infrações ${ }^{499}$. Nesse aspecto, consigna que é necessário que a lei defina os elementos mínimos (essenciais) desses Códigos de prevenção, cuja elaboração deve se

\footnotetext{
${ }^{494}$ Segundo a proposta legislativa de NIETO MARTín, especificamente o artigo 2, 1: "La persona jurídica es responsable por la comisión de un hecho delictivo realizado por cualquier persona física que actúe por su cuenta cuando no ha implementado o no lo ha hecho de manera eficaz un Código de prevención cone 1 fin de prevenir y descubrir la realización de esse tipo de delito. No existe responsabilidad penal se la persona jurídica cuenta con un Código de prevención eficaz.”. Id. Ibid., p. 324.

${ }^{495}$ Id. Ibid., p. 324.

${ }^{496}$ Id. Ibid., p. 325.

${ }^{497}$ Busca o autor a definição de pequena empresa contida na regra da Organização Internacional do trabalho (OIT). Id. Ibid., p. 325. Sua opção pelo reconhecimento da inimputabilidade nesses casos reafirma a dimensão organizativa em que fundada sua proposta de culpabilidade empresarial.

${ }^{498}$ Id. Ibid., p. 324-325. Nesse aspecto, cabível a distinção feita por LAMPE, dentro dos seus sistemas de injusto, entre agrupamentos criminais (agrupamentos institucionalmente organizados com objetivos criminais) e empresas econômicas com tendências criminais (unidade organizativa portada por um sujeito jurídico, que serve a um fim econômico cuja organização, fim ou persecução desse fim pode ter tendência criminal). LAMPE, Ernst-Joachim. La dogmática..., p. 111-119.
}

${ }^{499}$ Id. Ibid., p. 325 
fundar na técnica de valoração do risco e de regulação cooperativa ${ }^{500}$.

\subsection{Alguns posicionamentos críticos à culpabilidade da pessoa jurídica e suas ponderações sobre o defeito de organização}

Apesar dos diversos esforços dogmáticos para a construção de um conceito de culpabilidade adequado à pessoa jurídica, posicionamentos críticos a tal formulação remanescem, havendo mesmo quem negue a possibilidade de harmonização desse critério de imputação subjetiva ao ente coletivo ${ }^{501}$. Deve-se ressaltar, contudo, que alguns autores, mesmo avessos às formulações de culpabilidade própria da pessoa jurídica, tem se apoiado na ideia de defeito organizativo, mantendo sua relação com a responsabilidade da pessoa jurídica.

A despeito de refutarem a possibilidade das pessoas jurídicas lesionarem normas jurídico-penais de determinação e, portanto, de serem destinatárias de um juízo de reprovação penal, não negam que a dinâmica organizativa da pessoa jurídica é uma realidade favorecedora da prática delitiva pelas pessoas físicas que compõem a estrutura empresarial. Reconhecem, contudo, tal dinâmica, de forma objetiva, como um estado de coisas $^{502}$, um "estado perigoso" $" 503$, que não se confunde nem com a culpabilidade, nem com o injusto pessoal. Aliás, afirma-se não haver nesse estado qualquer caráter subjetivo, ressaltando que as construções de culpabilidade são falhas em distingui-la do próprio injusto $^{504}$.

Oportuno observar, todavia, como, mesmo nas versões críticas à culpabilidade

\footnotetext{
${ }^{500}$ Id. Ibid., p. 327.

${ }^{501}$ Nesse sentido, ressaltamos as críticas e interpretações de dois autores: JESÚS-MARÍA SILVA SÁNCHEZ e RICARDO ROBLES PLANAS.

${ }^{502}$ SILVA SÁNCHEZ, Jesús-María. La responsabilidad penal..., p. 35.

${ }^{503}$ Como esclarece ROBLES: “[...] los defectos organizativos no pueden definirse tampoco como actuaciones o manifestaciones de la voluntad de la persona jurídica, sino sólo como emanaciones (peligrosas) que exteriorizan unicamente las voluntades individuales que han compuesto y componen a la persona jurídica en el tempo, produciendo o permitiendo que aquella identidad abstracta llegue a tener una apariencia concreta. En este punto, la persona jurídica es siempre un sujeto inimputable cuya actividad no puede canalizarse jurídico-penalmente a través de "acciones". La persona jurídica es, pues, incapaz de imputación para el Derecho penal basado en la culpabilidad.”. ROBLES PLANAS, Ricardo. El “hecho propio”..., p. 7.

${ }^{504}$ Acrescenta ROBLES que tipificar especificamente os injustos da pessoas jurídicas também não seria adequado. Isto porque, não se verifica legitimação material do injusto penal como delito de perigo abstrato fundado na mera desorganização empresarial. Como afirma o autor: "[...] no es posible legitimar un tipo delictivo que castigue la no adopción de medidas organizativas empresariales en sí sólo por la mera posibilidad de que un tercero autorresponsable utilice a la persona jurídica como instrumento para delinquir. ROBLES PLANAS, Ricardo. ¿Delitos de personas jurídicas? A propósito de la Ley austríaca de responsabilidade de las agrupaciones por hechos delictivos. InDret, n. 2, p. 17, abr. 2006. Disponível em: <http://www.indret.com>. Acesso em: 06 jun. 2013.
} 
e à responsabilidade de natureza penal da pessoa jurídica, o defeito de organização permanece na composição da necessária responsabilização desses entes coletivos. Nesse sentido, é atraente a interpretação de SILVA SÁNCHEZ. Afirma o autor que o estado de coisas que configura o defeito de organização, ou o déficit de autorregulaão ou a dinâmica de grupo criminógena, trata-se de um injusto sistêmico ${ }^{505}$, que, apesar de não poder ser objetivamente típico (tendo-se em conta os tipos de autoria, impossíveis de serem realizados pela pessoa jurídica), constitui uma forma de cooperação ou favorecimento para a realização do delito pela pessoa física ${ }^{506}$. Deve, portanto, ser reprovado tal estado perigoso, ainda que não penalmente ${ }^{507}$. Assim, para a imposição de sanção (não penal), faz-se necessário verificar a existência de uma prática delitiva produzida por pessoa física e derivada de um defeito de organização da pessoa jurídica, que a favoreceu, imputando-se objetivamente a produção de um risco juridicamente desaprovado que permitiu a atuação delitiva da pessoa física ao modo de organização da pessoa jurídica. Deve-se observar, ademais, para a apuração da responsabilidade da pessoa jurídica, que o defeito de organização não foi corrigido no momento da decisão judicial e que é previsível que tal defeito venha a favorecer a prática de novos delitos no futuro ${ }^{508}$.

É interessante notar que, conquanto seja crítico à responsabilidade penal da pessoa jurídica, SILVA SÁNCHEZ não deixa de reconhecer que esta foi a opção do legislador espanhol, ou seja, integrar as sanções, que faticamente em nada se distinguiam das sanções de natureza administrativa, ao corpus simbólico-comunicativo do Direito Penal ${ }^{509}$. Encarando tal realidade, interpreta a responsabilidade penal da pessoa jurídica como componente de um Direito Penal de segunda velocidade, mais flexível, em que a "penalização" do ente coletivo demanda a imputação de "fatos" (nos moldes anteriormente

\footnotetext{
${ }^{505}$ Apesar de fazer uso do conceito de injusto sistêmico de LAMPE, não se pode dizer que fora tomado integralmente com o mesmo sentido, na medida em que não conclui SILVA SÁNCHEZ que o injusto sistêmico configura um injusto penal. Nesse sentido, é oportuno observar a crítica feita por RoBLES, para quem há uma pressuposição, por LAMPE, de que o injusto de sistema configuraria o injusto penal, pela mera conexão entre as três intâncias a que se pode imputar a lesão (pessoas físicas, pessoas jurídicas e garantes da pessoa jurídica). Ressalta ROBLES que o injusto de sistema não é injusto penal, porque a ele não se aplicam as regras de imputação típicas do delito, de forma que o caráter penal ressaltado por Lampe só é reconhecido, em verdade, pela existência de argumentos político-criminais. Id. Ibid., p. 16-17.

${ }^{506}$ SILVA SÁNCHEZ, Jesús-María. La responsabilidad penal..., p. 35

${ }^{507}$ Aliás, por essa leitura, nega que a pena aplicada à pessoa jurídica, tal como previsto no Código Penal espanhol, seja realmente pena.

${ }^{508}$ Cf. SILVA SÁNCHEZ, Jesús-María. La responsabilidad penal..., p. 36. É interessante observar que, conquanto tal leitura se faça na tentativa de adequação da previsão, no Còdigo penal espanhol, de uma responsabilidade penal da pessoa jurídica, conduz a um modelo de responsabilização não penal, fundado no defeito organizativo conectado à verificação da prática delitiva por pessoa física integrante da estrutura do ente coletivo. Estabelece, portanto, um modelo geral de imputação de responsabilidade à pessoa jurídica.

${ }^{509}$ Id. Ibid., p. 38.
} 
expostos como elaborados pelo aludido autor), constatando-se, contudo, a impossibilidade de se verificar uma culpabilidade da pessoa jurídica identificada com a culpabilidade individual.

Necessário consignar, ademais, que em seu modelo, a demonstração de uma organização adequada ${ }^{510}$ conduz à conclusão de que o delito cometido pela pessoa física no bojo da estrutura do ente coletivo não é imputável a um estado de coisas presente na pessoa jurídica, de forma que sua forma organizativa, conquanto tenha dado espaço a uma emanação delitiva, deve ser interpretado como um "estado neutro de cooperação".

De outro lado, mesmo para aqueles que, como RoBLES, veem na sanção uma intervenção patrimonial sobre a pessoa jurídica por ter havido em sua estrutura a prática de um delito, voltando-se, portanto, à neutralização do enriquecimento ilícito ${ }^{511}$, não deixa de reconhecer que o modelo de responsabilidade que se vem empregando (ainda que criticável), busca incentivar que as pessosa jurídicas adotem medidas a evitar o delito (do qual deriva o enriquecimento) $)^{512}$.

Assim, mesmo nas composições críticas da culpabilidade da pessoa jurídica, não se pode deixar de reconhecer o contributo das ideias relacionadas ao defeito de organização empresarial (bem como às considerações sobre ética empresarial e filosofia criminógena, que acabam integrando um conceito mais amplo de organização empresarial adequada) para a determinação da responsabilidade desse entes coletivos, ainda que fora do espectro penal.

\subsection{Conclusões preliminares sobre as construções teóricas de culpabilidade empresarial, conceitos equivalentes e suas críticas}

\footnotetext{
${ }^{510}$ SILVA SÁNCHEZ fala na existência de um programa de compliance operativo como conformador de um marco de risco permitido da pessoa jurídica. Id. Ibid., p. 37. Preferimos utilizar a expressão "organização adequada" porque ainda não tivemos oportunidade de discorrer sobre o conceito de programas de compliance. Por ora, parece-nos importante já deixar indicada a função sustentada por SILVA SÁNCHEZ a tais programas e apontar a existência de uma relação com a organização empresarial.

${ }^{511}$ Assim, mesmo com a previsão do Código Penal espanhol, a sanção dirigida à pessoa jurídica seria apenas nominalmente penal, dada sua função de intervenção patrimonial. Em verdade, como fundada numa regra de distribuição de custos (responsabilidade objetiva pelo perigo), a sanção estaria melhor alocada no Direito Civil ou Administrativo, na medida em que é uma responsabilidade especial ampliada, não baseada na culpabilidade, na medida em que surge como contrapartida do risco permitido especial que a atividade empresarial supõe e suas consequentes vantagens. Sobre isso, ver: ROBLES PLANAS, Ricardo. Pena y persona jurídica: crítica del articulo 31 bis CP. Diario La Ley, n. 7705, p. 1-ss, set. 2011. Disponível em: : <http://diariolaley.laley.es.> Acesso em: 06 jun. 2013. ROBLES PLANAS, Ricardo. El 'hecho propio'..., p. 8. Nesse sentido, também, COCA VILA, Ivó. ¿Programas de compliance..., p. 71.

${ }^{512}$ Reconhece ROBLES que um dos prontos centrais na moderna discussão da responsabilidade das pessoas jurídicas é a legitimação da intervenção para fomentar a colaboração da pessoa jurídica com o estado na atividade de prevenção de apuração de delitos. ROBLES PLANAS, Ricardo. El "hecho propio"..., p. 8-9.
} 
A breve análise efetuada sobre as diversas construções teóricas de culpabilidade da pessoa jurídica (ou mesmo as opções nominalmente diversas, mas com função equivalente, ao que indicam), permite-nos observar alguns pontos comuns que parecem orientar a busca pela compatibilização dogmática da responsabilidade penal do ente coletivo com esse elemento.

Em primeiro lugar, é perceptível que a tentativa de formulação de um conceito de culpabilidade (ou de um "semelhante") para a pessoa jurídica se pauta pela necessidade de superar a mera admissão formal de um equivalente conceitual. Em outras palavras, as construções teóricas (cada qual, é bem verdade, com suas limitações) vão se sucedendo na tentativa de afastar construções meramente formais de uma culpabilidade da pessoa jurídica, buscando dotá-las de um conteúdo. É nesse aspecto, então, que reside o principal desafio a ser enfrentado: a busca por um conceito material de culpabilidade da pessoa jurídica.

Para tanto, nem sempre há o recurso a um distanciamento das fórmulas de culpabilidade da pessoa física. Por vezes, as construções teóricas são expressamente fundadas na busca por um equivalente funcional à culpabilidade individual. Em outros casos, procura-se um conceito comum a ser aplicado em qualquer formulação de culpabilidade, seja ao indivíduo, seja à pessoa jurídica. Em muitas elaborações teóricas, contudo, o discurso é orientado pela desnecessidade de vinculação de uma construção de culpabilidade empresarial à sua origem humana, por assim dizer, demonstrando-se, nesse aspecto, que as objeções aventadas em relação à culpabilidade individual não podem ser aplicadas à culpabilidade da pessoa jurídica. Desse modo, as limitações constitucionais, ou mesmo as construções teóricas rechaçadas em relação à pessoa humana (como o Direito penal do autor, ou a culpabilidade pela condução de vida ${ }^{513}$ ), não podem ser automaticamente transportadas para a realização de uma crítica à culpabilidade da pessoa jurídica. Isto parece apontar para a existência de uma racionalidade própria à responsabilidade penal da pessoa jurídica, que não evidencia, todavia, a necessidade de construção de um sistema de responsabilização paralelo. A bem da verdade, a distinção interpretativa (que não permite aplicar necessariamente as mesmas objeções

\footnotetext{
${ }^{513}$ Sobre a culpabilidade pela condução de vida e sua relação com a culpabilidade empresarial, interessante a leitura de Silva Sánchez, que questiona criticamente a relação de tal construção com a possível reabilitação do honest vivere como princípio jurídico. Sobre isso, ver: SILVA SÁNCHEZ, Jesús-Maria. Honest vivere. InDret. n. 3, editorial, p. 1-3, 2010. Disponível em: $<$ http://www.indret.com/pdf/editorial2_es.pdf >. Acesso em: 05 jun. 2013.
} 
constitucionais, por exemplo, relativas à pessoa humana aos entes coletivos) funda-se na distinção entre os sujeitos, e não entre modelos de responsabilidade.

Quer-se com isso dizer que é possível a existência de um sistema único de responsabilização, o Direito Penal, tendo por base os mesmos critérios - como, por exemplo, a culpabilidade -, os quais serão equivalentes em sua função, mas distintos em seu conteúdo em face do sujeito a que se direcionam. Assim, num sistema único de responsabilidade (penal), o que influenciará a distinção interpretativa, ou seja, o conteúdo das categorias dogmáticas do delito, é a determinação do sujeito ${ }^{514}$.

Tendo-se em conta tal aspecto, é possível vislumbrar uma característica peculidar da culpabilidade relacionada à pessoa jurídica, que salta aos olhos por ter sido aventada por mais de uma das construções teóricas analisadas (ainda que de forma distinta) e que parece, portanto, essencial à determinação do conteúdo material dessa categoria sistemática: a dimensão temporal da apuração da culpabilidade do ente coletivo. Como se disse, nas mais diversas formulações teóricas houve a percepção de que a constatação da culpabilidade da pessoa jurídica só poderia se dar numa perspectiva temporal diversa daquela relacionada à pessoa humana, o que deriva de sua própria constituição pré-jurídica peculiar como sujeito, cuja existência não é individual, mas organizativa. Assim, nunca um juízo valorativo (pouco importando em que fundada tal valoração), mesmo aquele vulgarmente emanado do discurso social, poderia incidir sobre a análise de uma conduta isolada, pontual, posto que essa é própria dos seres humanos. Se o ser, existência, da pessoa jurídica é organizativo (o ente coletivo constitui sua existência por sua organização e atividade, o que se protrai no tempo), a valoração que recai sobre este sujeito só poderá ser emanada dessa peculiar situação temporal, não fixada num ponto único do tempo. Perceba-se que mesmo no discurso social leigo, o resultado que se valora pode ser determinado temporalmente, mas a atividade empresarial que o produz não. Assim, ao criticar-se uma empresa por certo ato danoso, na verdade não há um ato isolado em si

\footnotetext{
${ }^{514}$ Nesse aspecto, concordamos com Silvina BACIGALUPO, que, ao criticar o Código Penal espanhol por inserir a responsabilidade penal da pessoa jurídica nos "delitos especiais próprios", como se tratasse de uma subcategoria de autoria em delitos especiais, ressalta a necessidade de reconhecimento da pessoa jurídica como nova categoria de sujeito penal, verdadeiro requisito prévio ao sistema jurídico-penal. Afirma a autora: "La consideración de la persona jurídica como sujeto de Derecho penal nada tiene que ver con los problemas dogmáticos de imputación que generan los delitos especiales propios. La determinación del sujeto deve ser en todo caso un requisito previo del sistema jurídico (penal), pues condiciona de forma inexorable el contenido de las categorias dogmáticas de la teoría del delito. Por tanto, la determinación del sujeto es un aspecto que debe quedar resuelto con carácter previo. Como realidade prejurídica el paradigma del modelo de sujeto determina el contenido de las categorias dogmáticas de imputación.”. BACIGALUPO, Silvina. Los criterios de imputación..., p. 15
} 
danoso. O resultado (ou risco de sua produção) pode até ser isolado temporalmente, mas a atividade da qual ele deflui não é única, determinada temporalmente, mas sim derivada da complexidade da atividade empresarial.

Essa complexidade, aliás, para alguns autores, torna tão dificultosa a apuração de uma culpabilidade antecedente, que demandaria a apuração de uma culpabilidade pelo comportamento pós-delitivo, em face da reação da empresa à ação criminosa. A inserção do momento pós-delitivo na apuração da culpabilidade parece evidenciar, aliás, a conexão deste elemento sistemático a uma particular função da pena na responsabilidade penal da pessoa jurídica, que seria, ao que parece, incentivar a autorregulação.

Outro ponto essencial nas construções teóricas analisadas é a desmistificação da culpabilidade ${ }^{515}$. Não deve ser ela entendida como fim em si mesmo, capaz de objetar a própria admissão da responsabilidade penal da pessoa jurídica, mas reconhecida como categoria sistemática, cujo conteúdo deve ser orientado pelo discurso social. Assim, se a realidade social vem reconhecendo a pessoa jurídica como ator (aliás, protagonista) das relações sociais, em face das características que já tivemos oportunidade de apontar (domínio econômico, técnico-científico, influência na produção normativa e na cultura etc.), que justificaram, aliás, político-criminalmente a necessidade da responsabilização penal de tais entes; se na linguagem cotidiana formulam-se juízos ético-valorativos sobre as empresas; parece que esse papel social permite o reconhecimento de uma responsabilidade que pode ser eticamente valorada. De qualquer modo, o que importa é identificar o papel exercido pela categoria sistemática da culpabilidade, sem buscar limitações prévias em seu conteúdo que a incompatibilize com a responsabilidade penal dos entes coletivos.

Nesse sentido, parece que dois aspectos (que, aliás, são conexos) devem ser reconhecidos como funcionalmente essenciais à culpabilidade. Em primeiro lugar, sua presença é fundamental à demonstração da existência do exercício de um poder punitivo ${ }^{516}$

\footnotetext{
${ }^{515}$ Nesse aspecto, sobressai o pensamento de HEINE. Afirma o autor: "No vemos ninguna dificultad insuperable para admitir la premisa del "poder ser culpable" también con relación a las personas no naturales; es decir de plantearse la cuestión del por qué alguien puede ser de manera legítima declarado especialmente responsable. La "culpabilidad" es finalmente una categoría sistemática, cuyos requisitos se deciden normativamente en función a fundamentos socialmente consensuales (concepto de culpabilidad normativa) y cuyo contenido conceptual ya se orienta, en el derecho penal individual, de acuerdo a funciones específicas (derecho penal central, accesorio o administrativo). No existen mayores inconvenientes en ponerse de acuerdo sobre la "culpabilidad de las organizaciones" dentro de un sistema paralelo de responsabilidade colectiva.”. HEINE, Günther. La responsabilidad..., p. 67.

${ }^{516}$ Aqui vamos além do pensamento de HEINE, no sentido de interpretar a presença da culpabilidade não apenas como critério de demonstração de que um sistema paralelo se trata de Direito Penal. Sem adentrarmos na questão da necessidade de construção de um sistema paralelo para a responsabilização penal da pessoa
} 
estatal válido, dentro de um Estado Democrático de Direito. Assim, não se pode admitir qualquer forma de responsabilização da pessoa jurídica válida (que por meio do Direito Penal, quer por meio do Direito Administrativo Sancionador) sem a presença da culpabilidade, na medida em que ela servirá como parâmetro (ainda que não único) para a limitação do poder punitivo estatal. Aliás, nisto reside o segundo aspecto essencial da culpabilidade: evidenciar as causas que justificam a exclusão da responsabilidade penal.

Nesse ponto, parece-nos que uma formulação de culpabilidade da pessoa jurídica só poderá ser verdadeiramente culpabilidade quando possibilitar o reconhecimento de causas de exclusão da responsabilidade penal. Assim, à determinação do conteúdo da culpabilidade importa mais demonstrar critérios de exclusão da responsabilidade penal do que fundamentá-la, para o que será de extrema importância reconhecer que as empresas devem ser diferenciadas consoante a complexidade organizativa, dimensão, atividade que exercem, entre outros aspectos.

Em síntese, pode-se afirmar que na definição de uma culpabilidade na responsabilidade penal da pessoa jurídica, o reconhecimento desse peculiar sujeito penal (pessoa jurídica), determinará o conteúdo material dessa culpabilidade, que deverá ter em conta as singularidades desse sujeito, identificadas, de forma genérica, em sua dimensão temporal sui generis, como também, especificamente, pelas características do ente coletivo consideradas em cada caso específico. O dimensionamento desse conteúdo material da culpabilidade deve ter em conta, também, a função da sanção na responsabilidade penal da pessoa jurídica, que parece ter o objetivo de fomentar a autorregulação.

De outro lado, o conteúdo da culpabilidade não pode escapar de sua função de limitação do poder punitivo estatal, servindo, portanto, à identificação das causas de exclusão da responsabilidade penal.

Nesse aspecto, as exigências organizativas direcionadas à pessoa jurídica parecem atender de forma mais próxima aos aspectos material e funcional da culpabilidade da pessoa jurídica tal como constatados, tanto assim que, mesmo sob ângulos e nomenclaturas diversas, a valoração da dimensão organizativa tem sido o cerne da maioria das teses de construção de uma culpabilidade empresarial. Desse modo, dirige-se a

jurídica, entendemos que a presença da culpabilidade não demonstra apenas que o exercício do poder punitivo se trata efetivamente de Direito Penal, mas sim que este poder punitivo é válido, podendo ser exercido sobre a nomenclatura Direito Penal ou mesmo Direito Administrativo Sancionador. Isto porque, acreditamos que a culpabilidade também deve ser exigida neste segundo campo, o que, alías, fundamenta às críticas à opção por uma responsabilidade administrativa obejtiva inserida na Lei 12.846/2013. Remetemos, neste aspecto, o leitor ao capítulo segundo, item 2.2. 
reprovação ética para a não adoção de certa dimensão organizativa no bojo empresarial capaz de prevenir os riscos da atividade empresarial e de fomentar certa cultura de conformidade ao direito. Tal exigência deriva do reconhecimento social da pessoa jurídica como protagonista das relações sociais, porquanto detentora de conhecimentos técnicocientíficos necessários ao desenvolvimento de sua atividade, estando em relação de superioridade ao entorno social, o que torna inviável até mesmo a possibilidade de uma regulação adequada de suas atividades diretamente pelo Estado, demandando, bem por isso, uma participação ativa das empresas na definição de uma autorregulação.

A produção de um comportamento criminoso no bojo empresarial implicará a responsabilização empresarial se apurada sua culpabilidade, no sentido de verificar a inexistência de certa organização empresarial voltada à prevenção e apuração dessas condutas.

Tendo-se em conta, contudo, que certo conceito de culpabilidade apenas poderá ser assim reconhecido quando de seu conteúdo emanar causas de exclusão da responsabilidade penal, convertendo-se verdadeiramente em limite ao poder punitivo estatal, não se pode adotar uma conexão necessária entre a presença de comportamento criminoso no bojo da empresa e a conclusão de que houve, portanto, um defeito organizativo, posto que, assim, estar-se-ia contruindo uma "presunção de culpabilidade" fundada na presença do fato criminoso, transmudando a responsabilidade penal em responsabilidade objetiva. Bem por isso, tomando-se por base um possível conteúdo abstrato da culpabilidade - entendido como defeito organizativo em sentido amplo, abrangendo a ética empresarial - é necessário definir concretamente esta organização que se exige, tendo-se em conta as peculiaridades da pessoa jurídica (atividade que exerce, dimensão etc.), sem buscar delinear uma a uma as exigência desta organização, mas traçar uma perspectiva geral daquilo que a autorregulação empresarial deve conter. Nesse sentido, parece de extrema importância a determinação de programas de compliance para se dar concretude à culpabilidade empresarial, sobretudo no aspecto de limitação da responsabilidade penal. 


\section{COMPLIANCE E SUA POSSÍVEL RELAÇÃO COM A CULPABILIDADE EMPRESARIAL.}

A percepção de que a retomada da responsabilidade penal da pessoa jurídica derivou de necessidades político-criminais que apontavam para o protagonismo das pessoas jurídicas nas relações sociais, como detentoras de conhecimentos técnicos de atuação territorialmente difusa e, consequentemente, para a ineficiência do Estado em regular diretamente tais atividades (não só pela falta de tais conhecimentos, bem como pela incapacidade de acompanhar a velocidade das modificações tecnológicas e de estabelecer uma adequada regulação do complexo entramado organizativo que constitui as empresas, reconhecendo-se, nesse aspecto, sua peculiar situação de sistema autônomo), implicou na necessidade de se adotar uma estratégia diversa de regulação, instrumentalizando essa capacidade empresarial em favor dos objetivos estatais de prevenção e contenção de riscos. Nesse sentido, a autorregulação ${ }^{517}$ revelou-se como estratégia estatal para superar sua deficiência interventiva, concedendo efeitos jurídicos às soluções dadas pelas empresas ao definir sua organização.

O Direito Penal, então, revela-se como ultima ratio dessa autorregulação ${ }^{518}$, fomentando a estruturação de uma organização e de uma ética empresariais voltadas aos objetivos do Estado de prevenção da prática delitiva no bojo empresarial, fazendo incidir a sanção penal quando demonstrado que a empresa não adotou uma solução adequada à consecução de tais objetivos.

Pensa-se, contudo, que em nome da necessária limitação do poder punitivo estatal, não se poderia construir uma presunção de que, produzido o risco (ou dano) indesejado no bojo empresarial, necessariamente haveria a conclusão da existência da adoção de uma estruturação ético-organizativa inadecuada pelo ente coletivo que geraria a responsabilidade penal. Em verdade, seria necessário dimensionar critérios mínimos a serem seguidos pelas empresas, que se traduziriam não apenas em deveres, mas em verdadeiras garantias, no sentido de que a observância de tais critérios asseguraria às pessoas jurídicas a presunção (ainda que relativa) da adequação de seus procedimentos organizativos, isentando-as de responsabilidade pelas condutas criminosas praticadas em seu bojo.

\footnotetext{
${ }^{517}$ Sobre o tema da autorregulação, ver capítulo primeiro, item 1.5.3.

${ }^{518}$ Cf. NIETO MARTÍN, Adan. La responsabilidad..., p. 147.
} 
Nesse sentido, o desafio de delinear os modelos ético-organizaticos mínimos voltados ao objetivo estatal de controle de riscos parece passar, necessariamente, peal compreensão dos programas de compliance.

\subsection{Programas de compliance}

O termo compliance ${ }^{519}$, que pode ser traduzido para o português como “cumprimento", revela, semanticamente, a ideia de observância, atendimento. E esse é, realmente, o cerne de seu conteúdo: a busca pela observância das normas. Ainda que o termo compliance não seja exclusivo do Direito, nesse específico campo, que nos interessa, reflete o conceito de conformidade jurídica ${ }^{520}$.

Mas, no campo jurídico, a conformidade ao Direito é algo de sua própria essência (em especial no Direito Penal) ${ }^{521}$, de forma que, a primeira vista, o conceito não parece trazer uma definição própria. Afinal, buscar estar "em conformidade ao Direito" é algo íncito ao dever jurídico, de forma que toda pessoa, seja física ou jurídica, deve procurar. Bem por isso, o entendimento de compliance não se resume à busca por estar em conformidade ao Direito, mas sim, deve ser traduzido como um instrumento para estruturação empresarial de forma harmônica com o Direito ${ }^{522}$.

E como se deve entender essa "estruturação"? Devemos salientar, em primeiro lugar, que estamos aqui tratando da compreensão científica do conceito de compliance. Bem por isso, não buscaremos detalhar o conteúdo, ainda que mínimo, dos programas de compliance, que, ao que nos parece, está mais afeto à sua própria prática, ligada à ideia de assessoramento $^{523}$.

\footnotetext{
${ }^{519}$ Desde logo, é oportuno consignar que outros conceitos, além de programas de "compliance", são empregados para designar objetivos e procedimentos de direção empresarial (management). Fala-se, também (e aqui ainda fazendo uso dos anglicismos, até para não incorrer em traduções não empregadas na linguagem empresarial) de risk management, value management, corporate governance, business ethics, integrity codes, codes of conduct e corporate social responsibility. Observando essa pluralidade de termos, ULRICH SIEBER constata a impossibilidade de diferenciá-los precisamente, bem como a inviabilidade de sua definição clara. Verifica, contudo, que todos apontam para a orientação da direção empresarial para determinados objetivos, valores e procedimentos. SIEBER, Ulrich. Programas de compliance en el derecho penal de la empresa. Una nueva concepción para controlar la criminalidade económica. In: ARROYO ZAPATERO, Luis; NIETO MARTÍN, Adán (dir.). El derecho penal económico en la era compliance. Valencia: Tirant lo blanch, 2013, p. 64-66. Optamos pelo termo compliance e programas de compliance, em inglês, pelo seu emprego mais comum pela doutrina do Direito Penal e, em especial, nacionalmente.

${ }^{520}$ ROTSCH, Thomas. Criminal compliance. InDret, n. 1, p. 2, ene. 2012. Disponível em: <http://indret.com/pdf/876a.pdf>. Acesso em: 05 jun. 2013.

${ }^{521}$ Id. Ibid., p. 2.

${ }_{522}^{522}$ Id. Ibid. p. 2.

${ }^{523}$ Adotamos, aqui, a distinção feita por ROTSCH, para quem é necessário diferenciar, ao tratar dos problemas
} 
Presente, portanto, este enfoque científico, entende-se que os programas de compliance descrevem medidas a serem adotadas pela empresa com a finalidade de se organizar de forma a impedir a prática de crimes em seu bojo, bem como para incorporar em sua atividade uma cultura ética ${ }^{524}$. Podemos destacar, desse conceito, três aspectos que nos parecem essenciais aos programas de compliance: 1. Caráter preventivo; 2. Estabelecimento de certa dimensão organizativa empresarial; 3. Cultivo de uma cultura empresarial ética.

Em primeiro lugar, deve-se ter em conta que os programas de compliance se estruturam, no âmbito penal, em face do objetivo de prevenção da criminalidade ${ }^{525}$ e, consequentemente, de evitação de tal responsabilidade. Esse caráter preventivo não deve ser entendido como a evitação completa de qualquer delito no bojo empresarial (pois se, assim o fosse, a prática delitiva levaria à conclusão necessária da inexistência de um efetivo programa de compliance), mas como a minimização dos riscos produzidos pela atividade da empresa, até para que haja a compatibilização desse objetivo com os fins de tal atividade, voltados essencialmente para a maximização dos lucros. Para tanto, faz-se necessária a análise desses riscos, ou seja, dos fatores criminógenos existentes na empresa (e que, portanto, serão variáveis conforme a peculiaridade da estrutura empresarial e da atividade desenvolvida) e que tornam provável o surgimento do delito ${ }^{526}$. Nesse sentido, é perceptível que a função preventiva orientará a estruturação da organização empresarial, bem como o desenvolvimento de uma culrutra ética nesse meio.

Deve-se consignar, contudo, que os programas de compliance não se restringem a esse caráter "proativo". Em verdade, tem sido crescente a importância dada aos comportamentos pós-delitivos, outorgando-se relevo a medidas relacionadas à apuração e denúncia de delitos, bem como à alterações e atualizações dos programas já implementados em face da ocorrência de prática delitiva ${ }^{527}$. Buscar-se-á, portanto, dotar os

específicos de "criminal compliance", as questões relativas aos fundamentos científicos e as questões próprias da prática de assessoramento. Reconhece, contudo, que tais campos de compreensão não são isolados, havendo, em verdade, uma "retroalimentação" entre eles. Id. Ibid., p. 5

${ }^{524}$ SIEBER, Ulrich. Programas de compliance..., p. 64.

${ }^{525} \mathrm{Os}$ programas de compliance nasceram, ao menos na experiência europeia, fortemente vinculados à prevenção de fatos delitivos. É o que afirmam GONZÁLEZ FRANCO, SCHEMMEL E BLUMENBERG. Constatam os autores, contudo, que a finalidade de tais programas vai mais além do Direito Penal, relacionada à evitação dos riscos legais e reputacionais, bem como à geração de valor para a empresa. GONZÁLEZ FRANCO, J.A.; SCHEMMEL, A.; BLUMENBERG, A. La función del penalista en la confección, implementación y evaluación de los programas de cumplimiento. In: ARROYO ZAPATERO, Luis; NIETO MARTÍN, Adan (dir.). El derecho penal económico en la era compliance. Valencia: Tirant lo blanch, 2013, p. 155. A nós, contudo, importará este conceito mais conectado ao Direito Penal, em face do nosso objeto de estudo.

${ }^{526}$ Idem, p. 160.

${ }^{527}$ SIEBER, Ulrich. Programas de compliance..., p. 106. 
programas de compliance também de um caráter reativo, voltado à detecção e esclarecimento de delitos, caráter esse que não deixa de possuir - deve-se sublinhar - um fim preventivo, traduzido na evitação de futuras práticas delitivas.

Um segundo aspecto a ser ressaltado nos programas de compliance - aspecto esse orientado pelo objetivo preventivo já mencionado e que, no limite, busca a isenção ou minimização da responsabilidade da pessoa jurídica ${ }^{528}$-, é o dimensionamento da organização empresarial. Os programas de compliance devem estruturar a atividade empresarial de forma a angariar a máxima efetividade na minimização dos riscos, desenvolvendo, para tanto, um sistema de controle interno, com uma gestão dotada de transparência, fazendo uso das especializações técnicas presentes nas empresas, bem como do domínio de seus meios de direção e da possibilidade de sua atuação global, alcançandose, em síntese, uma autoproteção técnica para eliminar as estruturas criminógenas, além da implantação de sistemas sancionadores internos ${ }^{529}$.

O conteúdo e detalhamento dessas medidas são muito debatidos pela doutrina, sobretudo porque se sabe da incapacidade estatal para defini-las, uma vez que é necessário ponderar as especificidades de cada área de atuação das mais diferentes empresas, bem como as características internas desses entes (como tamanho, estrutura organizativa etc.). De outro lado, pretender tal delineamento seria, em verdade, improdutivo, diante da renovação necessária desses conteúdos, improvavelmente alcançada pelo tempo da produção legislativa. Afirma-se, contudo, que um mínimo de especificação legal se faz necessário, de forma a evitar a insegurança jurídica, sobretudo por se tratar, aqui, da relação dos programas de compliance com a responsabilidade dos entes coletivos, de forma que não se poderia deixar ao completo alvedrio judicial a determinação dessa estruturação exigida, observando-se que tal delineamento na sentença, ou seja, após a prática delitiva e a consequente responsabilização, inviabilizaria, ao que parece, o objetivo de fomentar a autorregulação $^{530}$.

\footnotetext{
${ }^{528}$ Entendemos que as medidas de compliance, quando adotadas em face da previsão de responsabilidade da pessoa jurídica, buscam formas de atenuar ou isentar tal responsabilização. Interessante, contudo, perceber que a doutrina alemã tem entendido a discussão do criminal compliance como uma reação à responsabilidade penal da pessoa jurídica. Isto porque, o compliance estabeleceria mecanismos de exculpação para a responsabilidade penal dos dirigentes das empresas, mecanismos estes que seriam desnecessários se houvesse uma responsabilidade penal originária do próprio ente coletivo. Nesse sentido: ROTSCH, Thomas. Criminal.... p. 7.

${ }^{529}$ SIEBER, Ulrich. Programas de compliance...., p. 103.

${ }^{530}$ As dificuldades na determinação dos conteúdos dos programas de compliance vão muito além do alcance de suas finalidades de eficiência na contenção dos riscos das atividades empresariais. A necessidade de adoção de tais programas como forma de se evitar ou minimizar a responsabilização da pessoa jurídica deve ser ponderada em relação à observância de direitos fundamentais. Nesse sentido, deve-se encontrar um limite
} 
É necessário, todavia, observar que esta estruturação organizativa não se cinge a pautar os comportamentos no bojo empresarial à conformidade com a lei. Como se disse, além das deficiências do próprio processo legislativo em abarcar as peculiaridades da organização empresarial e de responder em tempo adequado (e compatível com o progresso tecnológico) à necessidade de renovação dos conteúdos exigíveis a estes programas, deve-se notar, também, que o protagonismo das empresas como agentes sociais pode se refletir na produção legislativa, por meio do emprego de estratégias como a corrupção ou o lobby ${ }^{531}$. De outro lado, a vagueza do conteúdo legal (por vezes necessária para abarcar o maior espectro de situações possíveis) poderia ser utilizada pela empresa em seu favor. Ademais, estabelecendo-se um paralelo com as pessoas físicas, deve-se considerar que estas são influenciadas pela educação, socialização, entre outros aspectos, que são essencialmente colaboradores para a obediência à lei, não se podendo pretender que, em relação ao comportamento das pessoas jurídicas, a lei exerça a função de controle da conduta desviada de forma exclusiva ${ }^{532}$. Bem por isso, os programas de compliance devem ir mais além, incentivando uma cultura ética na empresa, o que não se limita à observância dos deveres legais ${ }^{533}$. Deve-se buscar a promoção de uma "responsabilidade social da empresa", o que pode significar, inclusive, a fixação de pautas de atuação em aspectos não regulados pela lei ${ }^{534}$.

entre a atividade de vigilência empresarial e o direito à intimidade dos trabalhadores, revelando, assim, a grande complexidade no dimensionamento de tais programas. Sobre o tema, ver: ALCÁCER GUIRAO, Rafael. Cumplimiento penal por la persona jurídica y derechos fundamentales: la intimidad como limite a la vigilância empresarial. Diario La Ley, ano XXXIV, n. 8053, Sección Doctrina, p. 1-202, abr. 2013. Disponível em:<http://diariolaley.laley.es>. Acesso em: 6 jun. 2013.

${ }^{531}$ A capacidade das empresas de influir na produção legislativa, como bem observa NIETO MARTín, deve ser enfrentada também com o avanço das normas anticorrupção (muito ligadas a necessidade de responsabilizarse as pessoas jurídicas, como tivemos oportunidade de verificar nos textos de alguns tratados internacionais), bem como com o aumento da transparência nos processos legislativo e com o combate ao financiamento irregular de partidos políticos. Cf. NIETO MARTíN, Adán. La responsabilidad..., p. 57.

${ }^{532}$ Ao constatar a necessidade dessa maior amplitude no controle dos comportamentos das sociedades, não se restringindo à mera obediência às normas jurídicas, NIETO MARTín ressalta que para a tradição jurídica intervencionista (característica da Europa e também do Brasil) são supreendentes as considerações relacionadas à ética empresarial ou à responsabilidade social empresarial, que se fundam, a bem da verdade, nestes argumentos que demonstram a desconfiança com relação à eficácia da lei. Cf. Id. Ibid., p. 219-220.

${ }^{533}$ Como afirmam DE LA MATA BARRANCO, BILBAO LORENTE E AlgORTA BordA: “[...] más allá del cumplimiento normativo, la empresa ha de adquirir (adquiere de hecho) con Protocolos de este tenor, desde su posición privilegiada de garante del comportamento de sus empleados, un compromiso social vinculado a un concepto de ética empresarial en la que el benefício de la actividad queda supeditado a un desarollo social (individual y colectivo) en el que la máxima se ala del respeto a los intereses ajeno merecedores de tutela legal y, especificamente, penal. DE LA MATA BARRANCO, Norberto Javier; BILBAO LORENTE, Martín. ALGORTA BORDA, Mariana. La atribuición de responsabilidade penal de las personas jurídicas y su exención: instrumentos de prevención en el seno corporativo. La Ley Penal, n. 87, nov. 2011, p. 10.

${ }^{534}$ Afirma NIETO MARTín: "Por este conjunto de razones, la ética jurídica propone, de un lado, incentivar una estrategia de cooperación entre administración, órganos de persecución y empresas, alejada de una posición de choque o constante recelo entre ambos frentes y, de otro lado, incentivar una cultura ética a través de la 
A importância do cultivo de uma cultura empresarial ética deve ser entendida, também, criminologicamente, observando a influência que o ambiente empresarial exerce sobre as condutas dos trabalhadores. A pressão por resultados traduzida na admissão do emprego de qualquer tipo de solução para seu alcance, a presença de um clima de erosão normativa, ou seja, uma atmosfera empresarial que dá espaço à prática de delitos, entre outros aspectos, são circunstâncias que não podem ser eludidas pela mera admissão de uma estruração organizativa formal na dita observância dos programas de compliance. Não basta a criação de órgãos de fiscalização, de meios de denúncia ou outras estruturas. É preciso, também, a transmissão crível de valores empresariais ${ }^{535}$. Portanto, é apenas com a incorporação do aspecto ético que os programas de compliance poderão alcançar seus objetivos preventivos de forma plena, não se convertendo em mero marketing empresarial.

Aliás, esse aspecto ético, que conduz os programas de compliance para além da mera atuação em conformidade com a norma posta, possibilita superar a crítica de alguns autores que não veem no compliance expressão da autorregulação, na medida em que limitam tais programas à positivação, no bojo empresarial, das medidas necessárias para atuar em conformidade com o direito já dado, ou seja, sem reconhecer nenhum poder configurador jurídico da empresa ${ }^{536}$.

Traçadas essas breves linhas, apenas com o objetivo de estabelecer um conceito de compliance, é importante visualizarmos como o tema é tratado nas legislações dos mais diversos países relacionadas à responsabilidade da pessoa jurídica. Nesse sentido,

promoción de la responsabilidad social de la empresa, la elaboración de programas éticos que fijen las pautas de actuación "cuando la ley se acaba", u otras formas de organización, como el nombreamiento de consejeros independientes que den una "voz en el consejo" de administración a los intereses colectivos - médio ambiente, consumidores, trabajadores.”. NIETO MARTÍN, Adán. La responsabiidad..., p. 220.

${ }_{535}$ Afirma SIEBER: "La investigación criminológica de la criminalidad económica demuestra que, para la criminalidad empresarial, resulta en primer lugar determinante la influencia específica de la empresa en la conducta de los trabajadores. Son sobre todo relevantes la actitude dentro de la empresa respecto a valores éticos así como la cultura organizativa que ella tiene y su estándard en cuanto a medida de compliance. Las infracciones a las normas son favorecidas especialmente por un clima de erosión normativa, por técnicas de neutralización al interior de la empresa para facilitar las violaciones normativas, por pressiones a los trabajadores para que encuentren "soluciones inovadoras" así como por oportunidades para la comisión de delitos. Es así que la transmisión creíble de valores empresariales, tal como pretenden los programas de compliance, tiene una gran importância para impedir la criminalidad empresarial.”. SIEBER, Ulrich. Programas de compliance..., p. 96.

${ }^{536}$ Este é o posicionamento de COCA VILA, que nega ser o compliance expressão da autorregulação. Afirma o autor: "En mi opinión, y en contra de la inmensa mayoría doctrinal, en la propia definición del Compliance se excluye la noción de autorregulación. Cuando se afirma que éste es un instrumento de minimización de riesgos jurídico-penales, y que el objetivo es evaluar esos riesgos para luego estabelecer medidas de conjura, implícitamente se está asumiendo que la empresa no tiene ningún poder configurador jurídico. Simplemente se la insta a que capte el mensaje público (en forma de riesgo jurídico-penalmente relevante), a que interprete qué puede y qué no puede suceder en el marco de su empresa, y a que lo transmita de la manera más clara posible a los integrantes de ésta.”. COCA VILA, Ivó. ¿Programas de Cumplimiento...,? p. 70. 
analisaremos (em linhas gerais, é bem verdade) a legislação americana sobre o tema compliance (especialmente as Sentencing Guidelines), bem como a legislação italiana, chilena e espanhola. A escolha se justifica. A abordagem da previsão norteamericana se dá, sobretudo, por as Sentencing Guidelines servirem de orientação para todos os modelos de programas de compliance. As legislações italiana e chilena vêm, na esteira, trazendo posições muito importantes relacionando os programas de compliance a causas de exoneração da responsabilidade da pessoa jurídica (salientando que no caso da Itália, não se fala de responsabilidade penal da pessoa jurídica, ainda que ocorra dentro do processo penal tal responsabilização), e a experiência espanhola apresenta algumas dificuldades semelhantes a que legislação brasileira mais atual parece ter que enfrentar.

Em seguida, teremos que verificar eventuais reflexos que os programas de compliance podem ter sobre a responsabilização da pessoa jurídica em face da legislação brasileira existente.

\subsection{Estados Unidos e as Sentencing Guidelines}

Publicadas em 1991, as Sentencing Guidelines for Organizational Offenders correspondem a um sistema orientativo do dimensionamento das penas ${ }^{537}$ referente à responsabilidade penal das pessoas jurídicas, destinado a oferecer ao julgador um parâmetro na fixação da sanção, buscando, com isso, harmonizar a prática judicial (que era muito díspare entre os Estados americanos) no sentido de um maior rigor na imposição de sanções ${ }^{538}$. Para tanto, faz uso de duas estratégias: a) carrots and sticks - atuando como um sistema de recompensas, busca-se a cooperação das empresas, diminuindo-se a sanção quando atuam para a prevenção e esclarecimento da prática delitiva e, ao contrário, exasperando-a quando tal comportamento positivo não é verificado; e, b) cooperate regulation -pretende canalizar o comportamento empresarial para uma autorregulação eficaz, fazendo uso, para tanto, das sanções positivas ou negativas ${ }^{539}$.

As Sentencing Guidelines revelam o reconhecimento do fracasso do modelo

\footnotetext{
${ }^{537}$ Como bem afirma URBINA GIMENO, as Guidelines não se referem à determinação da responsabilidade da empresa, mas partem do pressuposto de que tal responsabilização existe, cabendo a elas regular a imposição da pena concreta. ORTIZ DE URBINA GIMENO, Iñigo. Responsabilidad penal de las personas jurídicas y programas de cumplimiento empresarial (“compliance programs”). In: GOÑI SEIN, José Luis (dir.). Ética empresarial y código de conducta. Las Rozas, Madrid: La Ley, 2011, p. 126.

${ }^{538}$ As Sentencing Guidelines têm como antecedente o Model Penal Code de 1962, que em sua seção 2.07 compendiou todos os modelos de imputação existentes. Sobre isso, ver: NIETO MARTÍN, Adan. La responsabilidade penal..., p. 178-180.

${ }^{539}$ Id. Ibid., p. 181-182.
} 
intervencionista de controle das empresas, voltando-se para a cooperação delas e consequente corresponsabilização pela implementação de programas preventivos e investigativos de delitos em seu bojo. Tal implementação deverá refletir no dimensionamento da sanção, e terá como finalidade, portanto, motivar a autorregulação. Evidente, desse modo, que as normas contidas nas Guidelines traduzem a ideia de que uma empresa não pode ser eticamente indiferente aos riscos e resultados que produz em seu entorno $^{540}$.

Nesse aspecto, deve-se dizer que a culpabilidade empresarial (culpability score) tem especial importância nesse sistema, na medida em que, congregada ao dano social, servirá como critério para o dimensionamento da pena ${ }^{541}$. No sistema das Guidelines, a culpabilidade constitui um fator multiplicador da multa-base, fator esse cujo dimensionamento, partindo de um valor previamente fixado, varia em conformidade com as agravantes e atenuantes, que o compõe.

No específico tema dos programas de compliance, observa-se que estes funcionam como relevante circunstância atenuante da pena no sistema em análise, consistindo uma das principais peças nas Guidelines. É interessante notar que os programas, pelo seu próprio objetivo de efetividade na prevenção de riscos, devem se referir a uma específica classe de delitos, sendo necessário, para tal definição, verificar quais guardam relação (entendida como provável ocorrência) com a atividade desenvolvida pela empresa.

Não se descura, ademais, do comportamento pós-delitivo, inserindo-se a autodenúncia, cooperação e aceitação de responsabilidade como circunstâncais atenuantes, as quais, aliás, podem ser aplicadas de forma independente da existência de programas de compliance efetivos ${ }^{542}$.

Consigne-se, de outro lado, que para o agravamento da pena são considerados

\footnotetext{
${ }^{540}$ Id. Ibid., p. 183.

${ }^{541}$ Interessante observar que, para a determinação da multa a ser paga, o juiz deve considerar, em primeiro lugar, o tipo de empresa e a capacidade de pagamento dela. Em seguida, deve eleger, entre os critérios de "nível fixado pelo legislador", "ganhos obtidos com o delito" e "perdas derivadas da infração", aquele de valor mais elevado, para, então, com a multa-base, verificar o grau de culpabilidade da empresa que servirá como fator multiplicador dessa multa. Para maiores detalhes sobre o tema: Id. Ibid., p. 186-188.

${ }^{542}$ Neste aspecto, é importante a ressalva feita por NIETO MARTín, no sentido de que: "Si la existencia de un programa de cumplimiento sólo resultaba efectiva como atenuante vinculada a la autodenuncia, no ocorre a la inversa. Una corporación pude beneficiarse de esta atenuante sin disponer de programa alguno.”. Id. Ibid., p. 192. Perceba-se, com isso, que o aspecto pós-delitivo, traduzido na cooperação para investigação e autodenúncia, deve fazer parte de um programa de compliance para que seja avaliado como efetivo e, assim, possa surtir efeitos. Relacionando tais considerações à culpabilidade, parece haver a confirmação do aspecto temporal peculiar deste elemento quando relacionado à responsabilidade da pessoa jurídica.
} 
o nível hierárquico do agente envolvido ${ }^{543}$ na prática delitiva. Importante ressaltar, contudo, que tal fator de exasperação deverá ser ponderado em conformidade com o tamanho da empresa, de forma que nas de pequeno porte, até pela menor diluição havida na estrutura empresarial (que comporta poucas pessoas), a exaperação será menor, ainda que haja o envolvimento de um dirigente ${ }^{544}$.

Outras agravantes são o histórico criminal do grupo (reincidência), que dependerá da gravidade da infração e do tempo transcorrido, bem como a prática intencional de medidas destinadas a dificultar a investigação do delito ${ }^{545}$.

É oportuno observar, todavia, que a prática vem se afastando um pouco das orientações das Sentencing Guidelines, no que concerne ao específico aspecto relacionado aos efeitos da adoção dos programas de compliance, falando-se, até mesmo, na distorção desse sistema ${ }^{546}$. Isto porque, como se sabe, segundo as Guidelines, os efeitos da adoção dos programas de compliance se restringem a atenuação da pena, sem que possam implicar na isenção de responsabilidade. Tal raciocínio se justifica tendo-se em conta o modelo vicarial de responsabilidade penal da pessoa jurídica adotado pelo sistema americano, em que não se reconhece uma responsabilidade própria desse ente coletivo, mas transferida de seus componentes pessoas naturais. Assim, ainda que possível questionar os efeitos da apuração da culpabilidade da pessoa jurídica sobre o dimensionamento da sanção (interpretação essa que é cabível quando se reconhece como culpabilidade empresarial o defeito de organização e o relaciona à adoção ou não de efetivos programas de compliance, conduzindo, portanto, à identificação do modelo de responsabilidade não como puramente vicarial, mas misto $^{547}$ ), aquela nunca poderá implicar na completa exclusão da responsabilidade, pois remanescerá a reprovação resultante da transferência da culpabilidade do agente para a pessoa jurídica ${ }^{548}$.

\footnotetext{
${ }^{543}$ Diz-se "envolvido" porque não é necessário que o agente de grau superior na hierarquia empresarial tenha praticado o delito para que se reconheça uma maior culpabilidade e se exaspere a pena. Se este agente tolerar, consentir ou conscientemente ignorar a prática delitiva, a pena deverá ser mais alta.

${ }^{544}$ NIETO MARTÍN, Adan. La responsabilidade penal..., p. 188.

${ }^{545}$ Id. Ibid., p. 190.

${ }^{546}$ Id. Ibid., p. 210.

${ }^{547}$ Segundo NIETO MARTín: "Los modelos mixtos son aquellos que combinan el modelo de imputación vicarial o de transferência con la culpabilidad de empresa. Existen, en lo que conosco, tres ordenamentos que han acogido este sistema: USA, Italia y, mui recentemente, Austria.”. Id. Ibid., p. 177. Já segundo URBINA GIMENO: “[...] estas directrices no suponen el cambio del tradicional modelo vicarial vigente en los EE.UU. por algún tipo de modelo de autorresponsabilidad, sino que lo que hacen es incorporar aspectos del modelo de autorresponsabilidad en el momento de determinación de la pena concreta.". ORTIZ DE URBINA GIMENO, Iñigo. Responsabilidad penal..., p. 126.

${ }^{548}$ Afirma NIETO MARTíN: "Una de las características del modelo mixto norteamericano radica en que la culpabilidad de empresa nunca pude borrar la culpabilidad transferida. Siempre subsiste una multa residual,
} 
A prática processual, contudo, vem reconhecendo efetio diverso à adoção de efetivos programas de compliance a outro efeito. Em 1999, editou-se a Federal Prosecutors of Corporations (FPC), instrução governamental que define os parâmetros a serem seguidos na utilização do princípio da oportunidade processual em relação às pessoas jurídicas. Dentre os critérios previstos na lei, estão os programas de compliance, além da cooperação posterior ao delito, cuja aplicação antes do início do processo imuniza a empresa da persecução penal.

A bem da verdade, os acordos pré-processuais ${ }^{549}$ baseados na utilização de programas de compliance têm sido muito utilizados na resolução de casos de responsabilidade penal das empresas, mesmo antes da edição da FPC $^{550}$. Diante da constatação da ocorrência delitiva e de que os programas de compliance não foram adotados, ou o foram de forma insuficiente, as empresas têm se inclinado às exigências impostas pelos fiscais federais antes mesmo do iníco da persecução penal, como forma de evita-la. Para tanto, acabam consentindo com a adoção de um novo programa de compliance, inclusive com a modificação de sua estrutura, procedimentos internos e políticas.

Evidencia-se, portanto, que essa reestruturação por acordo pré-processual acaba por definir com certo detalhamento os modelos preventivos a serem adotados pela empresa, assemelhando-se, portanto, a verdadeiras "sentenças" no tema da responsabilização da pessoa jurídica ${ }^{551}$, acabando por substituir a jurisprudência que

por lo que podría hablarse de una excessiva orientación del sistema al autor individual. Esta opción legislativa se debe, en parte, a criterios de oportunidad política. Uno de los motivos de las Guidelines fue precisamente comunicar a la opinión pública el incremento de las sanciones contra personas jurídicas, ante la conciencia generalizada de que existía una gran benevolencia. No obstante, también se esgrimen en defensa de esta opción argumentos técnicos. En su estudio acerca de la eficiência de los distintos modelos de responsabilidad de las personas jurídica, Arlen/Kraakmann se muestran partidários de estabelecer siempre una multa residual (residual fine) que no pueda ser compensada por la ausência de culpabilidad de la empresa; ésta sería además una de las vantajas de los modelos mixtos frente al modelo de la culpabilidad de empresa. Suprimir la sanción residual supone liberar a la empresa de los custos sociales derivados del delito, además de que no incentiva a la empresa a mejorar sus deberes de prevención, por encima del nível exigido. Con ello se conjuraría el peligro de que, en su caso, las empresas se acomodaran a exigências de organización demasiado bajas.”. NIETO MARTÍN, Adan. La responsabilidade penal..., p. 205.

${ }^{549}$ Fala-se, especialmente, em dois tipos de acordo pré-processuais: Deferred prosecutions agreements e Nonprosecution agreementsi, muito utilizados nos Estados Unidos em matéria de responsabilidade penal empresarial. Sobre isso, ver: MORALES ROMERO, Marta Muñoz de. Programas de cumplimiento "efectivos" en la experiência comparada. In: ARROYO ZAPATERO, Luis; NIETO MARTÍN, Adan (dir.). El derecho penal económico en la era compliance. Valencia: Tirant lo blanch, 2013, p. 220.

${ }^{550} \mathrm{Já}$ em 1993, no caso Armour of America, se utilizou os programas de compliance como requisito para a aplicação de um acordo pré-processual. Cf. Id. Ibid., p. 221.

${ }^{551}$ Aliás, tais "pseudo-sentenças" são também orientadas em sua fixação por uma regulação à semelhança das Sentencing Guidelines, as chamadas United States Attorney's Manual (USAM), em especial em seu título 928.000, que trata dos Principles of Federal Prosecution of Business Organizations, extremamente detalhados em outros treze itens. Servem de pauta para os fiscais federais na definição dos encargos a serem fixados para 
deveria se formar ${ }^{552}$.

Diante de tais considerações, é invitável reconhecer que, mesmo por vias transversas, não relacionadas a uma exclusão da culpabilidade, a adoção de programas de compliance, no sistema norteamericano, tem revelado a capacidade de imunizar a empresa da responsabilidade penal, ainda que por acordos pré-processuais que os impõem.

\subsection{Itália}

A experiência italiana na responsabilidade da pessoa jurídica apresenta certa peculiaridade. Isto porque, pode-se dizer que o legislador italiano estabeleceu um tertius genus de responsabilidade, dotando-a de natureza administrativa, mas com garantias penais. O Decreto Legislativo 231 considera que a pessoa jurídica pode ser responsabilizada por um ilícito administrativo, ilícito esse que, contudo, depende de uma infração penal para a sua configuração ${ }^{553}$.

A aplicação dessa responsabilização à pessoa jurídica se dá em um restrito rol de delitos, todos dolosos e sempre relacionados ao benefício da empresa, excluindo-se, portanto, a responsabilidade de âmbitos importante, como o meio ambiente, ou seja, relacionados a infrações imprudentes e, portanto, ao risco da atividade empresarial ${ }^{554}$.

O modelo italiano apresenta algumas similitudes com as Sentencing Guidelines norteamericanas, demonstrando ter nelas se inspirado ${ }^{555}$. Utiliza-se do modelo vicarial de imputação, mas recorre a um defeito organizativo própria da empresa para a configuração da responsabilidade ${ }^{556}$. E, nesse particular aspecto, demonstra certa distinção em relação às

as empresas. Disponível em: <http://www.justice.gov/usao/eousa/foia_reading_room/usam/title9/28mcrm.htm>. Acesso em: 12 jul. 2013.

${ }^{552}$ Afirma MORALES ROMERO: "Ante la ausencia de un auténtico case-law en casos de corrupción no queda más remedio que acudir al "falso" case-law o "jurisprudencia de facto", si se prefere la expresión acuñada por Koheler, que constituyen los acuerdos pre-procesales.”. MORALES ROMERO, Marta Muñoz de. op. cit. p. 230.

${ }_{553}$ NIETO MARTÍN, Adan. La responsabilidad penal..., p. 196.

${ }^{554}$ Id. Ibid., p. 199. Parece-nos, contudo, que a legislação italiana se afastou, em certa medida, das motivações político-criminais à responsabilização da pessoa jurídica, muito afeta à prevenção dos riscos de suas atividades.

${ }^{555}$ Cf. ORTIZ DE URBINA GIMENO, Iñigo. Responsabilidad penal..., p. 129.

${ }^{556}$ NIETO MARTİN, Adan. La responsabilidad penal..., p. 195. Alguns autores, contudo, classificam este modelo de forma distinta do vicarial, chamando-o de misto justamente por fazer depender a responsabilidade da pessoa jurídica não somente da imputação do comportamente da pessoa natural à pessoa jurídica, mas também da apuração de um aspecto próprio da empresa, que no caso seria o "defeito de organização". Neste sentido: MATUS ACUÑA, Jean Pierre. La certificación de los programas de cumplimiento. In: ARROYO ZAPATERO, Luis; NIETO MARTÍN, Adan (dir.). El derecho penal económico en la era compliance. 
Guidelines. Enquanto a adoção de um modelo organizativo preventivo, pela natureza de sistema de determinação de penas das Guidelines, serve, em princípio, para medir a sanção ${ }^{557}$, no Decreto Legislativo 231/2001 a adoção de programas de compliance apresenta-se como forma de exclusão ou fundamentação da responsabilidade da pessoa jurídica, de forma que sua presença retira a possibilidade de sancionamento.

É interessante observar, contudo, que o modelo de imputação terá influência sobre o ônus probatório na apuração da responsabilidade, na medida em que o aludido decreto faz distinção entre o cometimento do delito por sujeito que está em posição de direção na empresa ${ }^{558}$, e a prática delitiva por subordinados ${ }^{559}$. No primeiro caso, caberá à pessoa jurídica demonstrar a existência de um eficaz programa de compliance e, portanto, de uma fraude cometida pela pessoa física para cometer o delito, como forma de se alcançar sua isenção de responsabilidade. Estabelece-se, portanto, uma inversão do ônus da prova. Já nos casos em que a prática delitiva se deu pela atuação de um subordinado na hierarquia empresarial, é possível a isenção de responsabilidade ainda que inexistente um programa de compliance $e^{560}$.

Observe-se, contudo, que o modelo de organização traçado pela legislação italiana demonstra valorizar o caráter preventivo dos programas de compliance, deixando de lado o aspecto reativo, sem menção à cooperação pós-delitiva na configuração de tais programas $^{561}$. Em verdade, o comportamento reativo se cinge à reparação do dano e à adoção de uma organização antes do início do "juízo oral”, funcionando apenas como causa de redução da pena, consoante o artigo 12, 2, do Decreto Legisativo 231/2001 ${ }^{562}$.

Em síntese, a legislação italiana prevê a influência da adoção dos programas de

Valencia: Tirant lo blanch, 2013, p. 150. DE LA MATA BARRANCO, Norberto Javier; BILBAO LORENTE, Martín; ALGORTA BORDA, Mariana. La atribuición de responsabilidad..., p. 8.

${ }^{557}$ NIETO MARTín faz uma importante observação com relação a esta distinção, salientando que, na prática, é possível que adoção dos programas de compliance previstos nas Sentencing Guidelines funcionem para a exculpação da responsabilidade da pessoa jurídica. Consigna o autor: "Esta diferencia, que a la hora de construir el modelo teórico es importante, en la práctica es quizás menos importante de lo que a primera vista pueda parecer. Ello es debido a que la existência de programas de cumplimiento es un critério que, como se ha visto, los órganos de persecución norteamericanos manejan en su utilización del principio de oportunidad procesal, por ello lo que ocorre en muchos casos es que por la vía de este principio unida a la de los acuerdos procesales también se crea un importante espacio para la exculpación total.”. NIETO MARTÍN, Adan. La responsabilidade..., p. 197.

558“"Soggeti in posizione apicale”, consoante o art.igo5.1.a) e artigo 6 do Decreto Legislativo 231.

559،"Soggeti sottoposti all'altri direzione", consoante o artigo 5.1.b) e artigo 7 do Decreto Legislativo 231.

${ }^{560}$ Cf. NIETO MARTíN, Adan. La responsabilidad..., p. 198.

${ }^{561}$ Id. Ibid., p. 197.

${ }^{562}$ Dispõe o articulado: 'La sanzione e' ridotta da un terzo alla meta' se, prima dela dichiarazione di apertura del dibattimento di primo grado: a) l'ente ha risarcito integralmente il danno e ha eliminato le conseguenze dannose o pericolose del reato ovvero si e' comunque efficacemente adoperato in tal senso; b) e' statp adottato e reso operativo un modello organizzativo idôneo a prevenire reati della specie di quello verificatosi.". 
compliance na responsabilização da pessoa jurídica, ainda que fazendo uso da distinção entre a posição hierárquica dos autores (pessoas físicas) na empresa para se estabelecer esse efeito e o ônus probatório. De qualquer modo, é possível que a existência de um programa de compliance eficaz redunde na isenção de responsabilidade do ente coletivo ${ }^{563}$.

\subsection{Chile}

A Lei 20.293/2009 foi expressa em estabelecer a responsabilidade de caráter penal da pessoa jurídica. A opção legislativa pela responsabilidade penal ${ }^{564}$ vem como forma do Estado chileno atender a uma série de compromissos internacionais, em especial, à exigência de contemplar em sua legislação sanções "eficazes, proporcionais e dissuasórias" às pessoas jurídicas ${ }^{565}$. Não havia, é bem verdade, a determinação expressa

\footnotetext{
${ }^{563}$ Afirma-se, contudo, que os tribunais italianos tem resistido à completa isenção da responsabilidade penal diante da implementação e adoção de um programa de ccompliance, sob o argumento de que a ocorrência do delito demonstra que tal programa não era idôneo para o fim preventivo a que se destinava. Nesse sentido: MATUS ACUÑA, Jean Pierre. La certificación..., p. 148-149.

${ }^{564}$ Há discussão quanto ao modelo de responsabilidade penal adotado pela lei chilena. Considerando-se que, para a responsabilização, é necessário haver um nexo de imputação entre a prática delitiva e o descumprimento de deveres de direção e supervisão, omissão esta que é realizada pela própria pessoa jurídica, sem a identificação de indivíduos como responsáveis pela omissão, pode-se dizer que está diante de um modelo de responsabilidade originária. No mesmo sentido, se observado que o artigo 5, intitulado "responsabilidade autônoma da pessoa jurídica" estabelece que tal responsabilidade é possível mesmos quando não mais cabível a responsabilização da pessoa física, que por morte, prescrição, ou pela decretação processual da suspensão temporal da causa. Contudo, o artigo 18 da mesma lei fala expressamente em "responsabilidade derivada", e o artigo 22 exige, para se formalizar o processo em face da pessoa jurídica, que haja a solicitação de audiência para a formalização da investigação da pessoa física, ou que tenha sido iniciado um processo em face dela. Enfim, a lei parece trazer argumentos para ambas as fundamentações. Nesse sentido, ver: ROJAS A. Luis Emilio. Ley 20393 de la República de Chile sobre responsabilidad penal de las personas jurídicas. Revista de Derecho Penal y Procesal Penal, n 5,p. 787, may. 2012.

${ }^{565}$ Como se vê, com a Lei 20.393 o Chile procurou atender as exigências para seu ingresso na OCDE, em especial aquelas contidas na Convenção sobre o Combate da Corrupção de Funcionário públicos Estrangeiros em Transações Comerciais Internacionais, que em seu artigo 2 dispõe sobre a "Responsabilidade de Pessoa Jurídicas", prevendo que "Cada Parte deverá tomar todas as medidas necessárias ao estabelecimento das responsabilidades de pessoas jurídicas pela corrupção de funcionário público estrangeiro, de acordo com seus princípios jurídicos"; acrescendo, ainda, no artigo 3.2 que "Caso a responsabilidade criminal, sob o sistema jurídico da Parte, não se aplique a pessoas jurídicas, a Parte deverá assegurar que as pessoas jurídicas estarão sujeitas a sançãoes não-criminais efetivas, proporcionais e dissuasivas contra a corrupção de funcionário público estrangeiro, inclusive sanções financeiras.”. Nesse sentido, é interessante a crítica que Héctor Hernández faz à admissão da responsabilidade penal da pessoa jurídica pelo legislador chileno por exclusiva influência externa. Afirma o autor: "Porque, en efecto, atendido el conocido desinterés del legislador chileno por atacar la criminalidade de empresa, la postura poco entusiasta y más bien renuente del conjunto de la doctrina nacional hacia la punibilidade de las personas jurídicas y la escassez previa de iniciativas legislativas en ese sentido, sin el fator externo hubiera sido apenas imaginable un giro tan radical. No es casual, entonces, la importância que el Mensaje del Ejecutivo (Boletín 6423-07) le atribuye no ya al cumplimiento de compromisos internacionales, sino específicamente al inminente ingreso como miembro pleno de la OCDE, importância que se destaco a lo largo de toda tramitación. No es otra cosa lo que explica que un proyecto tan complejo y sobre una matéria tan delicada se haya despachadoíntegramente en escasos siete meses de tramitación parlamentaria, justo a tempo para exhibirlo a la OCDE: se trataba de un "desafío-país" que había que superar a como diera lugar.”. HERNÁNDEZ, Hector. La introducción de la responsabilidad penal de las
} 
da aplicação de sanções de natureza penal. Contudo, a inexistência de tribunais administrativos, bem como de uma agênica administrativa de fiscalização única, fizeram o legislador chileno optar pela responsabilidade penal ${ }^{566}$.

Essa responsabilidade se limita a um específico rol de crimes, que inclui a lavagem de dinheiro, o financiamento de delitos terroristas, e a corrupção ativa de funcionários públicos nacionais ou estrangeiros (cf. artigo $1^{\circ}$ da Lei 20.393/09). O artigo $3^{\circ}$ da aludida Lei traz a previsão da forma de atribuição de responsabilidade ${ }^{567}$. Numa síntese, pode a pessoa jurídica ser responsabilizada pelos atos daqueles que compõe o ápice da estrutura hierárquica da empresa (donos, controladores, responsáveis, executivos principais, representantes ou quem realize atividades de administração ou supervisão), ou pelo comportamento de qualquer um que faça parte da estrutura empresarial, desde que esteja sob a supervisão direta de quaisquer das pessoas anteriormente citadas. Não se faz necessária, contudo, a identificação das pessoas físicas para se alcançar essa responsabilização, bastando a demonstração de que o delito fora cometido no âmbito de atribuições próprias desses indivíduos ${ }^{568}$.

Estabelecido o sujeito cuja ação pode levar à responsabilização da pessoa jurídica, é necessário, ademais, para que esta responsabilização possa se concretizar, que o

personas jurídica en Chile. Política Criminal, v. 5, n. 9, p. 208-209, jul. 2010. Disponível em: 〈http://politicacriminal.cl/Vol_05/n_09/Vol5N9A5.pdf>. Acesso em: 12 nov. 2012.

${ }^{566}$ Aliás, o projeto de lei original não falava de responsabilidade penal das pessoa jurídicas, mas de uma genérica "responsabilidade legal". Como bem explica LUIS EMILIO ROJAS: "El motivo para la introducción de una ley que estabelece la posibilidad de aplicar sanciones penales a las personas jurídicas radica en el cumplimiento del Estado de Chile de una serie de compromisos internacionales y, en particular, de la condición para el ingresso de éste a la Organización para la Cooperación y el Desarrollo Económico (OCDE), consistente en contemplar sanciones "eficaces, proporcionales y disuasorias" para estas personas. Por certo, las sanciones administrativas tienden también hacia estos fines; de hecho, el proyecto de ley original contemplaba la introducción de la "responsabilidad legal" de las personas jurídicas por estos delitos (mensaje 018-357). Sin embargo, la falta de una agencia administrativa única de fiscalización, así como la inexistência de tribunales administrativos, inclinaron la balanza hacia la respuesta penal, dando competência a los órganos de persecución penal. Esto explica que esta ley haya introducido la responsabilidad "penal" y no meramente "legal" de la persona jurídica.". ROJAS A., Luis Emilio. op. cit., p. 785.

${ }^{567}$ Artigo $3^{\circ}$ da Lei 20.393/09: “Atribución de responsabilidad penal. Las personas jurídicas serán responsables de los delitos señalados en el artículo $1^{\circ}$ que fueren cometidos directa e imediatamente en su interés o para su provecho, por sus dueños, controladores, responsables, ejecutivos principales, representantes o quienes realicen atividades de administración y supervisión, siempre que la comisión del delito fuere consecuencia del incumplimiento, por parte de ésta, de los deberes de dirección y supervisión. Bajo los mismos presupuestos del inciso anterior, serán también responsables las personas jurídicas por los delitos cometidos por personas naturales que estén bajo la dirección o supervisión directa de alguno de los sujetos mencionados en el inciso anterior. [...]".

${ }^{568}$ É o que prevê o artigo $5^{\circ}$ da Lei $20.393 / 09$ em sua parte final: "También podrá perseguirse dicha responsabilidad cuando, habiéndose acreditado la existencia de alguno de los delitos del artículo $1^{\circ} \mathrm{y}$ concurriendo los demás requisitos previstos en el artículo $3^{\circ}$, no haya sido posible establecer la participación de el o los responsables individuales, siempre y cuando en el processo respectivo se demonstrare fehacientemente que el delito debió necessariamente ser cometido dentro del ámbito de funciones y atribuiciones propias de las personas señaladas en el inciso primero del mencionado artículo $3^{\circ}$. ." 
delito tenha sido praticado no interesse ou proveito, ainda que indireto, do ente coletivo e que tenha sido decorrência do descumprimento dos deveres de direção e supervisão por parte da empresa.

Perceba-se que a lei chilena já estabelece como condição para a configuração da responsabilidade penal da pessoa jurídica o não cumprimento de deveres de direção e supervisão, o que permite caracterizar um modelo de responsabilidade mista, forma atenuada, por assim dizer, da responsabilidade derivada, em que, apesar de ser necessário constatar o ato dos dirigentes ou empregados (ainda que não se exija sua identificação), esta mera conexão formal não basta para a configuração da responsabilidade. Exige-se ademais, o descumprimento, pela pessoa jurídica, dos mencionados deveres de direção e supervisão $^{569}$. Mas no que consistiriam tais deveres? O próprio legislador esclarece no mesmo articulado, prevendo que tais deveres estarão cumpridos quando a pessoa jurídica houver adotado e implementado modelos de organização, administração e supervisão para prevenir delitos ${ }^{570}$. Deixa claro, portanto, a finalidade preventiva destes programas, e que não basta sua adoção formal, devendo-se demonstrar sua implementação.

A lei já estabelece um conteúdo mínimo dos programas de compliance para o atendimento dos deveres de direção e supervisão, definindo como principais elementos desses "modelos de prevenção", segundo o artigo $4^{\circ}$ da referida lei: a designação de um "encarregado de prevenção"; a definição de meios e faculdades para esse encarregado com independência em relação à gerência da empresa; o estabelecimento de um sistema de prevenção e de sanções internas; e a supervisão e eventual certificação do sistema ${ }^{571}$.

Em primeiro lugar, deve-se ressaltar que a lei estabeleceu a adoção dos modelos de prevenção como uma faculdade à pessoa jurídica ${ }^{572}$, o que demonstra que tais modelos, tal como detalhado pela referida lei, não constituem o único meio de se cumprir os deveres de direção e supervisão impostos à empresa ${ }^{573}$. De igual modo, mesmo que

\footnotetext{
${ }^{569}$ Responsabilidade por "defeito de organização". Nesse sentido: HERNÁNDEZ BASUALTO, Héctor. op. cit., p. 217.

${ }^{570}$ Artigo $3^{\circ}$ da Lei 20.393/09: “[...] Se considerará que los deberes de dirección y supervisión se han cumplido cuando, con anterioridad a la comisión del delito, la persona jurídica hubiere adoptado e implementado modelos de organización, administración y supervisión para prevenir delitos como el cometido, conforme a lo dispuesto en el artículo seguiente.".

${ }^{571}$ Uma das modificações no texto legal que se empreendeu na discussão parlamentar fora justamente em relação à flexibilização dessa "definição" do programa de "compliance", que era excessivamente detalhado na regulação original. Sobre isso, ver: MATUS ACUÑA, Jean Pierre. La certificación..., p. 145-146.

${ }^{572}$ Assim dispõe o artigo $4^{\circ}$ em sua parte inicial: "Modelo de prevención de los delitos. Para los efectos previstos en el inciso tercero del artículo anterior, las personas jurídicas podrán adoptar el modelo de prevención a que allí se have referencia, el que deberá contener a lo menos los siguentes elementos: [...]”.

${ }^{573}$ Sobre isso, afirma HERNÁNDEZ BASUALTO: "Será tarea jurisprudencial precisar cuándo las medidas de prevención delictiva adoptadas por una entidade sin modelo de prevención en los términos del art. $4^{\circ}$ pueden
} 
adotado um programa dessa natureza, sua certificação não é obrigatória ${ }^{574}$.

Essa certificação pode ser expedida por empresas de auditoria externa, classificadoras de risco ou outras entidades, desde que registradas na Superintendência de Valores e Seguros ${ }^{575}$. O certificado deverá conter um período de vigência, que não poderá ser superior a dois anos ${ }^{576}$.

Discute-se na doutrina, contudo, os efeitos que tais certificações possuem sobre a responsabilidade penal. Observando-se o histórico das discussões legislativas que deram origem à Lei 20.393, verifica-se que no projeto de origem falava-se expressamente do caráter de presunção legal dos certificados ${ }^{577}$, e a supressão posterior dessa locução não decorreu de qualquer posicionamento contrário a tal interpretação ${ }^{578}$. Com isso, certificada a adoção de um modelo de prevenção, haveria um impedimento de atribuição de responsabilidade penal à pessoa jurídica ${ }^{579}$.

Contudo, haveria nessa certificação uma presunção absoluta? Também com base nos antecedentes legislativos, e tendo-se em conta, ademais, que a lei não traz expressamente a menção a qualquer tipo de presunção, diz-se que não, a "presunção legal" não é absoluta e poderia ser afastada pelo Ministério Público ${ }^{580}$. O benefício, portanto, significa que, nos casos em que certificados os programas de compliance, caberá ao parquet um maior labor na produção de provas para desbancar a presunção constituída,

considerarse equivalentes a la adopción de dicho modelo y, en consecuencia, liberan de responsabilidade.”. HERNÁNDEZ BASUALTO, Héctor. op. cit., p. 226.

${ }^{574}$ Artigo $4^{\circ}, 4$, b): "Las personas jurídicas podrán obetener la certificación de la adopción e implementación de su modelo de prevención de delitos. En el certificado constará que dicho modelo contempla todos los requisitos estabelecidos en los numerales 1), 2) y 3) anteriores, en relación a la situación, tamaño, giro, nível de ingresos y complejidad de la persona jurídica.".

${ }^{575}$ A Superintendência de Valores e Seguros, equivalente funcional da SEC norteamericana, editou a norma de caráter geral $\mathrm{n}^{\mathbf{0}} 302$, de 25 de janeiro de 2011, estabelecendo as regras a serem observadas pelas empresas responsáveis pela certificação. Interessante observar que define haver incompatibilidade das entidades certificadoras para prestarem serviços de certificação quando: "a) A la misma persona jurídica a la que la entidade certificadora, o una relacionada a ésta, le presto servicios de asesoramiento o consultoria para efectos del diseño o implementación de su modelo de prevención de delitos. b) A las personas jurídicas que integram el grupo empresarial al que pertence la persona jurídica a la que la entidade certificadora presto servicios de asesoramiento o consultoría para efectos del diseño o implementación de su modelo de prevención de delitos. c) A las personas jur'diicas integrantes del grupo empresarial al que la entidade certificadora pertenece.". Sobre o tema, ver, também: MATUS ACUÑA, Jean Pierre. La certificación..., p. 146-147.

${ }^{576}$ Id. Ibid., p. 147.

${ }^{577}$ Assim constava originariamente no artigo 4\%: "El certificado constituirá presunción legal de la existência y pertinência del modelo de prevención de los delitos adoptado por la persona jurídica.". Conferir: BIBLIOTECA DEL CONGRESO NACIONAL DE CHILE. Historia de la Ley $n^{\circ} 20.393$, p. 248. Disponível em: <http://www.leychile.cl/Consulta/portada_hl?tipo_norma=XXI\&nro_ley=20.393\&anio=2013>. Acesso em: 09 jul. 2013.

${ }^{578}$ Cf. HERNÁNDEZ BASUALTO, Héctor. op. cit., p. 227.

${ }^{579} \mathrm{Cf}$. ROJAS A., Luis Emilio. op. cit., p. 787.

${ }^{580}$ Cf. HERNÁNDEZ BASUALTO, Héctor. op. cit., p. 227. 
diversamente das situações em que as empresas não optaram por adotar um modelo de prevenção certificado. Diante de tal intepretação, parece, em verdade, que a certificação influenciará, portanto, no ônus da prova $^{581}$.

Outro argumento que poderia ser levantado para defender a isenção de responsabilidade em face da certificação dos programas de compliance se fundaria no próprio modelo de responsabilidade penal adotado. Se se tratasse de um modelo vicarial, ocorrido o delito no bojo empresarial necessariamente este seria imputado à pessoa jurídica, de forma que a existência de programas de compliance não teria reflexos sobre a configuração da responsabilidade, mas apenas sobre o dimensionamento da sanção. Diversamente, contudo, quando se exige um defeito de organização como requisito da imputação (como no caso da lei chilena, em que se fala expressamente no descumprimento dos deveres de supervisão e direção para a configuração delitiva), a adoção dos modelos de prevenção certificados implicaria na necessária exclusão da responsabilidade.

Todavia, defende-se, também, que a certificação dos programas de compliance só poderia ter o efeito de atenuação da pena, tal como nas Sentencing Guidelines. Afirmase, em primeiro lugar, que em face do custo financeiro para se obter a certificação, esta acabaria se identificando com uma espécie de "bula papal". Tal como as bulas que, adquiridas, garantiam o acesso ao paraíso independentemente das virtudes de quem as comprava, a certificação acabaria por se conveter em um bem de mercado, de acesso exclusivo a empresas dotadas de maior capital, e que constituiria uma isenção de responsabilidade penal ex ante ${ }^{582}$.

Consigna-se, de outra banda, que a certificação teria o condão de atestar uma "boa cidadania" da pessoa jurídica que, se determinasse a isenção de pena, demonstraria a admissão de um direito penal do autor, e não do fato ${ }^{583}$. Ademais, o certificado pode se converter em um meio de burla para a perpetuação da prática delitiva no bojo empresarial, na medida em que, se efetivamente constitui uma isenção de responsabilidade ex ante, as pessoas jurídicas certificadas poderiam incentivar, de alguma forma (inclusive com a

\footnotetext{
${ }^{581}$ Mas, mesmo com a certificação, pode-se entender que essa inversão do ônus da prova não é absoluta. Nesse sentido, afirma HERNÁNDEZ BASUALTO: "Si bien en principio puede verse en esto una inversión de la carga de la prueba, no pude desconocerse que cuando un sujeto especialmente relacionado con una persona jurídica comete un delito directa e imediatamente en interés de ella o para su provecho es muy probablemente porque algo no está funcionado bien en la entidade, de modo que el delito es un indicio flerte de incumplimiento de deberes que pesan sobre la misma. Si esto es así, no parece objetable que el Minsterio Público pueda descansar al menos en principio en ese indicio, limitándose a acreditar los dos primero requisitos de la responsabilidad en tanto la entidad no aporte antecedentes pausibles del debido cumplimiento de sus deberes.". Id. Ibid., p. 227.

${ }^{582}$ Cf. MATUS ACUÑA, Jean Pierre. La certificación..., p. 151 e 153-154.

${ }^{583}$ Id. Ibid., p. 152.
} 
contratação de pessoas especialmente remuneradas para assumir a responsabilidade por eventuais delitos), a prática delitiva que lhes fosse benéfica ${ }^{584}$.

Ressalta-se, também, como argumento contrário à função eximente exercida pela certificação, que haveria uma disparidade de tratamento entre pessoas físicas e jurídicas, uma vez que as pessoas naturais que exercem atividades de risco, mas que têm certificação para tanto (seja por exames de certas categorias profissionais, seja por portar certa titulação), não gozam de qualquer isenção prévia de eventual responsabilidade penal em sua atividade ${ }^{585}$.

Deve-se observar, todavia, que a Lei 20.393/09, em seu artigo $6^{\circ}$, prevê como atenuantes da pena a notícia, pela pessoa jurídica, da prática delitiva às autoridades, antes da ciência de sua persecução formal, bem como a adoção, antes do início do julgamento, de medidas eficazes para prevenir a reiteração da mesma classe de delitos objeto da investigação. Tais medidas normalmente fazem parte de programas de compliance, o que poderia levar à conclusão de que, efetivamente, a adoção de medidas de prevenção apenas teria o efeito de atenuar a sanção, sobretudo se considerado que as medidas preventivas antes do início da persecução penal formal poderiam ser anteriores à prática delitiva ${ }^{586}$. Parece, contudo, que a distinção dessas causas em um artigo próprio, não referidas na explicitação dos modelos de prevenção, modelos esses diretamente relacionados com os deveres de direção e supervisão que compõe a configuração da responsabilidade penal da pessoa jurídica, indica que deve haver um tratamento diferenciado, não podendo interpretálos todos de igual modo, como atenuantes de pena.

\subsection{Espanha}

A Lei Orgânica 5/2010, que alterou o Código Penal espanhol, previu expressamente, a responsabilidade penal da pessoa jurídica, em seu artigo 31 bis. Optou a regulação pelo princípio da excepcionalidade, no sentido de que a responsabilidade penal desses entes coletivos só poderá se dar em relação a um determinado catálogo de delitos ${ }^{587}$.

\footnotetext{
${ }^{584}$ Id. Ibid., p. 152-153.

${ }^{585}$ Id. Ibid., p. 153.

${ }^{586}$ Id. Ibid., p. 150.

${ }^{587}$ Observa DíEZ RIPOLLÉs que nesse catálogo de delitos predominam aqueles relacionados a bens jurídicos sócio-econômicos, bem como à delinquência organizada, apesar da inclusão de outros crimes de caráter patrimonial ou assemelhados. Ressalta, contudo, que para os demais delitos, não previstos neste específico rol, é possível a aplicação de consequências acessórias, consoante o artigo 129 do Código Penal Espanhol, devendo-se observar, contudo, que, com a reforma de 2010, tais consequências só poderão ser aplicadas a
} 
Pode-se dizer que o artigo 31 bis 1 traz duas modalidades de responsabilização da pessoa jurídica. Em primeiro lugar, há a previsão de que tais entes serão penalmente responsáveis pelos delitos cometidos por seus representantes legais ou administradores de fato ou de direito, exigindo-se que tais delitos tenham sido praticados em nome ou por conta da pessoa jurídica, e em seu proveito. De outro lado, o mesmo articulado prevê, em seu segundo parágrafo, que tais entes também serão penalmente responsáveis pelos delitos cometidos, no exercício de atividades sociais e por conta e em proveito destas pessoas jurídicas, por aqueles que, estando submetidos à autoridade das pessoas físicas mencionadas no parágrafo anterior (ou seja, representantes legais e administradores), puderam realizar conduta criminosa por não ter havido o exercício, sobre eles, do devido controle.

Consigne-se, desde logo, que o aludido artigo é fonte de inúmeras divergências interpretativas na doutrina espanhola, o que já se inicia pela própria definição do modelo de responsabilidade penal adotado ${ }^{588}$. Para alguns autores, o legislador da reforma de 2010 optou por implantar um modelo de transferência de responsabilidade ou vicarial, na medida em que há a imputação, para a pessoa jurídica, de fato injusto praticado por seus administradores, representantes ou empregados ${ }^{589}$. Ainda que haja outras exigências conjuntas para a verificação dessa responsabilização, como o fato da ação ter sido realizada em nome ou por conta da pessoa jurídica e em seu proveito, certo é que essa responsabilização dependeria da verificação do injusto na pessoa física, ainda que não se exija a identificação desta (consoante dispõe o artigo 31 bis 2 do Código Penal espanhol $^{590}$ ). Teria havido a admissão legal, então, de uma responsabilidade penal da pessoa jurídica por fato injusto alheio ${ }^{591}$.

entes sem personalidade, o que gera certa disfuncionalidade. Critica o autor, ademias, a escassa previsão, nesse rol, de modalidades delitivas de comissão imprudente, o que demonstra nítido contraste com a realidade criminológica. DÍEZ RIPOLLÉS, José Luis. La responsabilidad penal de las personas jurídicas. Regulación española. InDret, n.1, p. 13-14, jan. 2012.

${ }^{588}$ Como afirma DEL ROSAL BLASCO: "Efectivamente, no parece que los autores se logren poner de acuerdo sobre cuál es, exatamente, de los modelos que antes hemos expuesto, el elegido por el legislador de la Reforma de 2010." DEL ROSAL BLASCO, Bernardo. Responsabilidad penal de empresas y códigos de buena conducta corporativa. Diario La Ley, ano XXXI, n. 7670, Sección Doctrina, p. 6, 11 jul. 2011. Disponível em: <http://www.laley.com.br>. Acesso em: 06 jun. 2013.

${ }^{589}$ Nesse sentido: DİEZ RIPOLLÉS, José Luis. La responsabilidad penal..., p. 14. ZUÑIGA RODRÍGUEZ, Laura. Responsabilidad penal de las personas jurídicas y criminalidade organizada. Consideraciones de urgência sobre la reforma al CP de 2010. In: MUÑOZ CONDE, Francisco. et al. (dir.). Un derecho penal comprometido. Valencia: Tirant lo blanch, 2011, p. 1171-1172.

${ }^{590}$ Segundo o referido articulado: "La responsabilidade penal de las personas jurídicas será exigible siempre que se constate la comisión de un delito que haya tenido que cometerse por quien ostente los cargos o funciones aludidas en el apartado anterior, aun cuando la concreta persona física responsable no haya 
Há, contudo, relevante setor da doutrina que vislumbra nessa previsão legal a introdução de um modelo de autorresponsabilidade da pessoa jurídica ${ }^{592}$. Reconhece-se a imputação de injusto culpável próprio da pessoa jurídica, apoiado na ideia de "defeito de organização". Para tal conclusão, fala-se que a exigência do "devido controle", contida expressamente no segundo parágrafo do artigo 31 bis 1 , apesar de relacionada à prática delitiva pelos empregados da pessoa jurídica, deve ser projetado como requisito também no primeiro parágrafo, ou seja, para a atuação dos administradores e representantes da sociedade ${ }^{593}$. Afirma-se tal extensão sob o argumento de que a observância de princípios constitucionais e jurídico-penais, como a exclusão da responsabilidade por fato alheio, imputação subjetiva e culpabilidade, impediriam orientação diversa ${ }^{594}$.

Reafirmam tal modelo, ademais, com base no fato do legislador ter previsto a responsabilidade da pessoa jurídica de forma independente da identificação da pessoa física, consoante o já mencionado artigo 31 bis 2 .

sido individualizada o no haya sido posible dirigir el procedimento contra ella.[...]" (grifo nosso).

${ }^{591}$ É oportuno consignar, no entanto, que tal interpretação não implica no necessário reconhecimento de uma culpabilidade e punibilidade transferidas da pessoa física para a jurídica. Neste sentido, aliás, DíEz RIPOLLÉs, reconhecendo o modelo como de responsabilidade transferida, assevera que a culpabilidade e a punibilidade são próprias da pessoa jurídica. Deixa claro, no entanto, que a culpabilidade é imputada estritamente a partir do fato injusto transferido à pessoa jurídica, consistindo, portanto, num juízo desvalorativo de caráter geral, reprovando a sociedade pelo comportamento antojurídico praticado em seu bojo, sem que haja a possibilidade de matização ou exclusão dessa reprovação. Diante de tal constatação, vislumbra em tal culpabilidade certa semelhança como o conceito de culpabilidade próprio da concepção normativa pura de WELZEL, uma vez que a pessoa jurídica, como criação do direito, seria exigível uma estrutura e atividade confome ao direito. DÍEZ RIPOLLÉS, José Luis. La responsabilidad penal..., p. 16. Este raciocínio parece confirmar a hipótese anteriormente aventada no presente trabalho (capítulo quarto, item 4.3) de que os modelos de responsabilidade, entendidos como modelos de imputação, não estão necessariamente relacionados a um modelo de culpabilidade (transferida ou própria).

${ }^{592} \mathrm{Cf}$. ZULGADÍA ESPINAR, José Miguel. Societas delinquere potest. Análisis de la reforma operada en el Código Penal español por la LP 5/2010, de 22 de junio. La Ley Penal: Revista de Derecho Penal, Procesal y Penitenciario, n. 76, p. 2, nov. 2010.

${ }^{593}$ Neste sentido, ROSO CAÑADILA, apesar de reconhecer duas fontes de imputação na responsabilidade penal da pessoa jurídica contida no $\mathrm{CP}$ espanhol, quais sejam, o proveito (relacionado ao primeiro parágrafo do artigo 31 bis 1) e a falta de controle (relacionado ao segundo parágrafo), chega a conclusão de que "el requisito indispensable en amabas fuentes es la falta de una organización eficiente y adecuada en el seno de la persona jurídica que evite gestiones dolosas o imprudentes por parte de su equipo directivo. Se impone la era del control eficiente como barrera de contención de los riesgos delictivos.". ROSO CAÑADILLAS, Raquel. Las fuentes de imputación de la responsabilidad penal corporativa. La Ley Penal: Revista de Derecho Penal, procesal y penitenciário, n. 81, p. 57-59, abr. 2011.

${ }^{594}$ Id. Ibid., p. 18. Esta é a interpretação adotada por ORTIZ DE URBINA GIMENO: "Así pues, pareciera que, paraa el caso de los sujetos individuales con poder de dirección, el legislador habría optado por el modelo de la imputación directa. Sin embargo, y como se explico en el apartado anteriroo, este modelo no es aceptable, dado que no garantiza en todos los casos el respeto del principio de responsabilidad subjetiva. Así pues, no queda otra alternativa que entender que, a pesar de que no se haga una referencia expresa a tal circunstancia, el artículo ha de ser interpretado conforme a la Constituición en el sentido de requerir la infracción del deber de cuidado por parte de la empresa.". ORTIZ DE URBINA GIMENO, Iñigo. Responsabilidad penal..., p. 123. 
Agora, o que nos importa mais especialmente, ou seja, em relação à eventual previsão dos efeitos dos programas de compliance nessa responsabilidade penal da pessoa jurídica, deve-se dizer que nesse campo também não há consenso doutrinário. Note-se, em primeiro lugar, que o artigo 31 bis 4 prevê, indubitavelmente, uma circunstância atenuante da pena relacionada ao estabelecimento de medidas eficazes para prevenir e descobrir os delitos que no futuro possam ser cometidos com os meios ou no bojo da pessoa jurídica. Essa atenuante tem, contudo, uma caracterísitica temporal muito específica, pois a implementação dessas medidas deve se dar após a prática de um delito na empresa e antes do começo do "juízo oral”.

Pelas características das medidas, tal como descritas no articulado em análise, não se pode deixar de reconhecê-las como englobadas pelo conceito de programa de compliance. Contudo, foram limitadas ao caráter reativo em face de um comportamento delitivo prévio, identificando-se, portanto, com uma função “preventiva a posteriore”, por assim dizer, no sentido de que (a despeito da contradição dos termos) a prevenção objetiva a não reiteração de uma prática criminosa já verificada.

Não haveria, portanto, na legislação espanhola, o reconhecimento dos programas de compliance como causas de exoneração ou isenção da responsabilidade penal $^{595}$ ? Nesse aspecto é que as divergências doutrinárias saltam aos olhos. Há uma significativa corrente interpretativa que sustenta que o "devido controle", cuja ausência é exigida no artigo 31 bis 1, segunda parte, do Código Penal espanhol, como requisito para a verificação da responsabilidade penal da pessoa jurídica (aqui sem adentrarmos na discussão sobre ser esse requisito exigível nos dois critérios de imputação previstos no aludido articulado), teria seu conteúdo preenchido pelos programas de compliance. Desse modo, o exercício do devido controle se verificaria com a existência de uma estrutura organizativa capaz de desenvolver a atividade empresarial em conformidade com as exigências legais, além de requerer a prévia identificação de riscos ${ }^{596}$.

\footnotetext{
${ }^{595}$ Usa-se, aqui, termos gerais como exoneração ou isenção, porque é variada a interpretação que se pode dar sobre os efeitos da adoção de programas de compliance efetivos sobre a responsabilidade penal da pessoa jurídica, dada a inexistência de expressa pevisão legal. Assim, pode ser vista como causa de atipicidade, pela própria inexistência de configuração do tipo subjetivo, já que a empresa não infringe seu dever de cuidado; como também pode ser interpretada como eximente de responsabilidade. Sobre isso, ver: Id, Ibid., p. 130.

${ }^{596} \mathrm{Cf}$. BACHMAIER WINTER, Lorena. Responsabilidad penal de las personas jurídicas: definición y elementos de un programa de compliance. Diario La Ley, n. 7398, Sección Tribuna, p. 1, 5 oct. 2012. Disponível em: 〈http://www.diariolaley.laley.es>. Acesso em: 05 jun. 2013.
} 
Para se alcançar um contorno mínimo desses programas de compliance, ante a inexistência de definição legal, os autores têm recorrido às experiências legais estrangeiras (em especial, ao modelo das Sentencing Guidelines, além da UK Bribery Act de 2010 e das leis italiana e chilena sobre o tema), como também a algumas legislações internas setoriais espanholas ${ }^{597}$, para tentar traçar um conteúdo essencial desses programas.

O que importa, portanto, é que, a despeito da inexistência de expressa previsão legal, existe na doutrina espanhola a intepretação de que a adoção de programas de compliance pode fazer com que a pessoa jurídica não seja responsabilizada pela comentimento de um delito em seu bojo, demonstrando, assim, a busca por relacionar o devido controle com a ideia de uma estrutura organizativa eficiente para a prevenção e detecção de delitos, voltando-se ao objetivo de fomentar uma autorregulação empresarial $^{598}$. O reconhecimento da circunstância atenuante inscrita no artigo 31 bis 4 remanesceria para os casos em que as empresas não possuem planos de redução de riscos antes da prática delitiva e depois de tal ocorrência vieram a adotá-los, e não para aquelas que os incorporaram de forma prévia ${ }^{599}$.

Não se pode olvidar, é bem verdade, de interpretação diversa, no sentido de que o "devido controle" seria uma exigência não voltada à empresa, mas aos administradores, de forma que, como exigência pessoal, não se satisfaria com a adoção de programas de compliance $e^{600}$. Nesse contexto, seria inviável interpretar a implementação de tais programas antes da prática delitiva como forma de isentar a pessoa jurídica de responsabilidade.

Deve-se observar, contudo, que há Projeto de Lei de reforma do Código Penal espanhol que, dentre diversos aspectos de modificação, pretende alterar o artigo 31 bis, ou

\footnotetext{
${ }^{597}$ Como a Lei 10/2010, que trata da prevenção da lavagem de dinheiro e financiamento do terrorismo; o Código Unificado de Bom Governo de Sociedades por Cotas; além da Lei 24/1998, do Mercado de Valores. Sobre isso, ver: VELÁZQUEZ VIOQUE, David. Responsabilidad penal de las empresas. ¿Cómo probar el debido control? Diario La Ley, n. 7794, Sección Tribuna, p. 2, 9 fev. 2012. Disponível em: <http://www.diariolaley.laley.es>. Acesso em: 06 jun. 2013.

${ }^{598}$ Sobre isso, ver: BACHMAIER WINTER, Lorena. Responsabilidad penal..., p. 2. ORTIZ DE URBINA GIMENO, Iñigo. Responsabilidad penal..., p. 126-131. VELÁZQUEZ VIOQUE, David. Responsabilidad penal..., p. 1.

${ }_{599}$ Cf. ORTIZ DE URBINA GIMENO, Iñigo. Responsabilidad penal...,p. 129-130.

${ }^{600}$ Assim afirma DEL ROSAL BLASCO: "Ni siquiera en el caso del supuesto de la falta de debido control de los administradores o de los representantes legales sobre los empleados, que ha permitido la comisión de delitos por parte de éstos, determinado la responsabilidad de la persona jurídica (art. 31 bis, núm 1, segundo párrafo) hay base legal suficiente para poder decir que esse debido control se satisface teniendo estabelecidos en la empresa códigos de buena conducta corporativa o compliance programs, porque el debido control es una exigência persona a los administradores o a los representantes legales, no a la organización como tal.". DEL ROSAL BLASCO, Bernardo. Responsabilidad penal..., p. 9.
} 
seja, a regulação existente em relação à responsabilidade penal da pessoa jurídica ${ }^{601}$. Nesse sentido, mantendo a previsão de duas modalidades de responsabilização (com apenas algumas modificações redacionais), o aludido projeto inova ao prever expressamente a adoção de programas de compliance como causa de isenção de responsabilidade da pessoa jurídica, a ser aplicada em ambos os casos, ou seja, tanto para os delitos cometidos por pessoas ocupantes de posição hierárquica superior na empresa, como para os subordinados. Para tanto, descreve com certo detalhamento os requisitos mínimos dos modelos de organização e gestão, modelos esses que devem ser adotados e executados com eficácia antes da prática delitiva; incluir medida de vigilância e controle voltadas para a prevenção delitiv;, além do que devem ser supervisionados por um órgão da pessoa jurídica.

Interessante observar, ademais, que nos casos em que os requisitos de tais modelos não puderem ser verificados em sua integralidade, ou seja, em que houver uma acreditação parcial dos programas de compliance, estes podem ser valorados como circunstância atenuante da pena ${ }^{602}$.

Diante desse projeto, é possível observar uma tendência ao reconhecimento da adoção de programas de compliance como causa de isenção da responsabilidade penal da pessoa jurídica, concedendo, ao que parece, maior incentivo à autorregulação.

\subsection{Os programas de compliance e a responsabilidade da pessoa jurídica no Brasil.}

Como tivemos oportunidade de analisar, a responsabilidade penal da pessoa jurídica no Brasil foi expressamente prevista pela Lei 9.605/98, que trata dos crimes ambientais, a despeito de algumas vozes dissonantes que não viram nessa previsão uma verdadeira superação do adágio latino societas delinquere non potest ${ }^{603}$.

A referida lei, em seu artigo $3^{\circ}$, faz uso do modelo vicarial de responsabilidade, transferindo-a do agente pessoa física ou de seu órgão colegiado à pessoa jurídica,

\footnotetext{
${ }^{601} \mathrm{O}$ referido Projeto de Lei está disponível em: <http://www.mjusticia.gob.es/cs/Satellite/1292419196744?blobheader=application\%2Fpdf\&blobheadername $1=$ Content -

Disposition\&blobheadervalue $1=$ attachment\%3B+filename\%3DArticulado_APLO_C\%C3\%B3digo_Penal__ 200913.pdf>. Acesso em: 01 out. 2013.

${ }^{602}$ Assim disporá o artigo 31 bis 2, em sua parte final, segundo o Projeto de Lei em análise: "En los casos en los que las anteriores circunstancias solamente puedan ser objeto de acreditación parcial, esta circunstancia será valorada a los efecros de atenuación de la pena.".

${ }^{603}$ Para um maior detalhamento desta questão, remetemos o leitor ao capítulo segundo, item 2.1.2.
} 
exigindo-se, ademais, que a prática delitiva tenha se dado em benefício ou no interesse da entidade. Nesse sentido, a previsão legal é muito restrita, falando apenas dos delitos cometidos pela decisão dos altos diretores (representante legal, contratual ou órgão colegiado). Não permite envolver, contudo, os delitos praticados por empregados derivados da falta de vigilância e controle adequado de seus superiores hierárquicos. Assim, nesse aspecto, poderia se afirmar que, por uma análise estrita dos vocábulos empregados no aludido articulado no delineamento da responsabilidade penal da pessoa jurídica, não se encontra espaço para questionamentos atinentes a defeitos organizativos na estrutura empresarial.

Talvez fosse possível vislumbrar certos requisitos relacionados aos programas de compliance entre as circunstâncias atenuantes elencadas no artigo 14 da Lei 9.605/98, em especial nos incisos III e IV, ao tratarem da comunicação prévia do perigo iminente de degradação ambiental e colaboração com os agentes encarregados de vigilância e controle ambiental. Tais aspectos, contudo, são muito limitados, tendo-se em conta o caráter mais ampliado dos programas de compliance, sobretudo em seu aspecto preventivo, voltado a uma estruturação organizacional da empresa por longo prazo.

Desse modo, a Lei 9.605, se alguma referência faz a um comportamento prévio da empresa como forma de atenuar-lhe a pena (pena, aliás, que encontra entraves em sua própria fixação, ante a ausência de uma regulação adequada pela referia lei), é de forma muito incipente, relacionada não tanto a busca de uma autorregulação empresarial, mas ao caráter de crimes de perigo dos delitos ambientais. Presente esse espectro, conclui-se que eventual inserção da avaliação do defeito organizativo na responsabilidade penal da pessoa jurídica poderia se dar apenas por considerações interpretativas relacionadas à teoria geral do delito, no caso, a apuração de uma culpabilidade empresarial, sem qualquer apoio em previsão legislativa que pudesse abrir espaço para incluir tal interpretação no texto legal.

Nesse aspecto, então, parece que, a Lei 12.846/2013, conquanto não trate da responsabilidade de caráter penal, tem a importância de trazer para o debate nacional questionamentos sobre os efeitos da adoção de modelos de prevenção sobre a responsabilização da pessoa jurídica. Isso porque, como já se disse, em seu artigo $7^{\circ}$, inciso VIII, traz a previsão de que, na aplicação das sanções será levada em consideração a “existência de mecanismos e procedimentos internos de integridade, auditoria e incentivo à 
denúncia de irregularidades e a aplicação efetiva de códigos de ética e de conduta no âmbito da pessoa jurídica".

Evidencia-se em tal previsão uma estratégia de autorregulação fundada em estruturas de estímulos. Busca-se que as empresas se organizem de forma a adotar mecanismos de integridade e auditoria ${ }^{604}$, além de denunciar constatação de irregularidades em seu bojo, pretendendo-se, ademais, a adoção de códigos de ética e conduta, incentivo que é dado com a consideração favorável de tais aspectos no dimensionamento da sanção administrativa.

Deve-se dizer, contudo, que é impossível não se constatar nessa previsão certa insegurança jurídica. O emprego de expressões vagas e abertas, sem a precisão de um conteúdo mínimo dos mecanismos e procedimentos a serem adotados, muito menos do que se pode entender por aplicação efetiva de códigos de ética e de conduta, não permite um conhecimento prévio do mínimo exigido a empresa para se enquadrar nesse modelo preventivo. Nesse sentido, parece que nos aproximamos das dificuldades colocadas pelo Código Penal espanhol à aplicação da responsabilidade penal da pessoa jurídica, ao não definir o "devido controle" que as empresas deveriam exercer sobre seus funcionários, cuja ausência gera a responsabilização dos mencionados entes coletivos pelos delitos de seus empregados (cf. artigo 31 bis 1 do CP espanhol), muito menos as "medidas eficazes para prevenir e descobrir delitos" que configuram atenuantes da responsabilidade penal das pessoas jurídicas (cf. artigo 31 bis 4 do CP espanhol).

Questiona-se, também, se a estratégia adotada, com estímulo somente no dimensionamento da sanção, é a mais adequada no fomento à autorregulação e na busca de uma organização da pessoa jurídica de forma a prevenir delitos, que se tem por mais eficiente do que a regulação estatal direta. Tendo-se em conta a tendência internacional ao reconhecimento da adoção dos programas de compliance como forma de isentar a pessoa jurídica de sua responsabilidade, tendência esta percebida não só legislativamente (lei italiana ou projeto de lei espanhol), como também na prática processual (nesse sentido, os

\footnotetext{
604 Auditoria e compliance não podem ser confundidos. Como ressalta CALLEGARI: "Em verdade, o compliance ainda está muito ligado à ideia de auditoria no Brasil, entretanto, salvo algumas semelhanças, os dois institutos não deveriam ser confundidos. A auditoria tem um sistema de verificação aleatório e por determinado período, enquanto o compliance tem suas funções exercidas rotineira e permanentemente. Em apertada síntese, enquanto o compliance integra a estrutura de controle, a auditoria avalia a tal estrutura, sem, contudo, integra-la.". CALLEGARI, Andre Luís. Compliance no Brasil: a necessidade da quebra de conceitos equivocados acerca da cultura da conformidade. Disponível em: $<$ http://lecnews.com/novo/compliance-no-brasil -a-necessidade-da-quebra-de-conceitos-equivocados-acercada-cultura-da-conformidade/>. Acesso em: 31 out. 2013.
} 
acordos pré-processuais americanos que tem evitado a responsabilização das pessoas jurídicas quando efetivamente implementados modelos de prevenção e detecção de delitos, conquanto não fosse esse o sentido da Sentencing Guidelines), pensa-se que o Brasil ainda terá que dar um passo além para incentivar uma nova racionalidade nas empresas, que deve considerar não só os aspectos reputacionais da adoção dos programas de compliance, como também seus efeitos (exoneratórios, pensa-se) sobre a responsabilidade de tais entes.

\subsection{Conclusões preliminares a respeito da relação entre programas de compliance, culpabilidade da pessoa jurídica e autorregulação empresarial.}

Retomando o enfoque científico em que abordamos o conceito de programas de compliance, fora possível perceber três características essenciais: prevenção (pré e pósdelitiva), organização e ética.

Como se disse, os programas de compliance, voltados ao objetivo preventivo de contenção de riscos - objetivo esse que se orienta de forma não só prospectiva, mas também reativa (nesse útlimo aspecto, como prevenção à prática de novos delitos) -, englobam a busca não só por uma organização empresarial estruturalmente adequada, como também eticamente correta, ética essa refletida no comprometimento com uma atuação socialmente responsável (inclusive no sentido de fixação de pautas em aspectos ainda não regulados pela lei, demonstrando, com isso, que a conformidade ao Direito vai além da conformidade normativa) e com a introdução, na atuação empresarial, de uma "filosofia" voltada para esse comprometimento.

Nessa conceituação, portanto, pensa-se ser possível vislumbrar a abrangência dos conteúdos fundamentais das principais construções teóricas relativas à culpabilidade da pessoa jurídica. Reflete não só o aspecto organizacional (e, assim, a culpabilidade pelo defeito organização) como o une à ética empresarial (e, portanto, aos questionamentos destinados à adoção de uma cultura de cumprimento à legalidade e a uma filosofia empresarial não criminógena). Não promove, dessa forma, uma abordagem estanque de quaisquer desses aspectos teóricos, envolvendo-os de forma congregada no mesmo objetivo preventivo de contenção dos riscos. 
Aliás, no que concerne a esse fim preventivo, deve-se dizer que aí reside outro espaço de intrínseca relação entre os programas de compliance e os modelos teóricos de culpabilidade da pessoa jurídica. O peculiar aspecto temporal da culpabilidade dos entes coletivos (apontado por diversas concepções teóricas, como tivemos oportunidade de concluir $^{605}$ ) integra os programas de compliance, na medida em que a prevenção objetivada é considerada não apenas antes da prática criminosa, mas também no comportamento empresarial posterior ao advento do delito, voltado para a evitação de futuras práticas.

Deve-se consignar, todavia, que a relação entre programas de compliance e modelos teóricos de culpabilidade empresarial não se limita à sua definição conceitual, estendendo-se, também, às suas funções. Isto porque (e talvez melhor esclarecendo), como se observou na análise das mais diversas legislações sobre o tema, os programas têm sido empregados (ainda que por vias pré-processuais) como causas de exoneração ou isenção de responsabilidade penal das pessoas jurídicas. Esse é um efeito, aliás, que mesmo entre as legislações que não o reconhece expressamente, vem sendo debatido na doutrina, influenciando futuras mudanças nos textos legais (como o caso espanhol).

Dessa forma, constatar-se nos programas de compliance uma materialização da culpabilidade empresarial demandaria que sua efetiva incorporação pelas empresas tivesse a aptidão de afastar a responsabilidade penal. Com isso, haveria a exaltação do caráter garantístico contido na culpabilidade, no sentido de limitação do jus puniendi estatal ${ }^{606}$.

De outro lado, pode-se sustentar que apenas diante do caráter exoneratório da responsabilidade penal é que se poderia fomentar a autorregulação. Em outras palavras, para se incentivar a adoção dos programas de compliance, seria necessário que seus efeitos não se limitassem à atenuação da pena, mas que pudessem constituir verdadeiras formas de isenção da reprimenda penal. Claro que tal efeito passa por um requisito prévio, justamente o reconhecimento da relação entre programas de compliance e autorregulação que, como se disse, depende da maior amplitude conceitual que se conceda a tais programas,

\footnotetext{
${ }^{605}$ Sobre o tema, ver capítulo quinto, item 5.3.

${ }^{606}$ Poderíamos desse modo, talvez, aproximar a culpabilidade empresarial do conceito de culpabilidade elaborado por RoXIN, não em relação ao conteúdo, mas à sua função. Afinal, como constatamos no capítulo terceiro, item 3.2, na segunda fase de seu pensamento, RoxIN moveu o eixo da relação entre culpabilidade e prevenção para uma relação mais disfuncional, realçando as vantagens garantísticas do princípio da culpabilidade, reconhecendo-o como meio de limitar a sanção orientada pelo escopo preventivo. Assim, mesmo no campo empresarial, podemos pensar que a culpabilidade não fundamenta a necessidade da pena, mas circunscreve o âmbito de sua admissibilidade.
} 
englobando, também, aspectos éticos, permitindo que em seu bojo estejam fixadas pautas de atuação relacionadas a caracteres não regulados pela lei.

É bem verdade que há interpretação no sentido de que aspectos éticos, principiológicos e mesmo medidas adotadas pelas empresas que transbordem a prevenção de riscos tal como estabelecida pelo legislador (ou seja, que ultrapassem a regulação voltada para a atuação conforme um direito já dado), não poderiam ter efeitos sobre o Direito Penal, precisamente por serem expressão de autorregulação, ou seja, de uma capacidade da empresa de configuração jurídica, capacidade essa cujos efeitos deveriam se limitar ao âmbito privado, sem influências sobre o direito público ${ }^{607}$. Pensa-se, contudo, que tal leitura nega a própria noção de autorregulação regulada, compreendida como um mecanismo de regulação misto pelo qual o Estado busca se valer das próprias empresas, instrumentalizando as normas privadas para a consecução dos objetivos públicos ${ }^{608}$. A negação de qualquer efeito das normas privadas sobre o direito público seria, no limite, a negação da própria possibilidade de autorregulação regulada, e não só pelo Direito Penal, mas também por meio do Direito Administrativo Sancionador, que faz parte do direito público $^{609}$.

Desse modo, parece-nos, que estabelecer uma relação entre programas de compliance e um possível conceito de culpabilidade da pessoa jurídica não seria um juízo equivocado. Em primeiro lugar, porque, conceitualmente, os aspectos abrangidos pelos programas de compliance relacionam-se proximamente com os modelos teóricos que pretenderam construir uma culpabilidade da pessoa jurídica. De outro lado, funcionalmente, pensa-se que os programas de compliance podem conceder um substrato à

\footnotetext{
${ }^{607}$ Essa é a interpretação de COCA VILA. Segundo o autor. “[...] los Programas de Cumplimiento son la herramienta fundamental para la positivación de las medidas necessárias, pero en todo caso, para actuar conforme a un Derecho ya dado, que, como no podría ser de otra manera en el ámbito de Derecho penal, es público. Por lo demás, aquellas medidas que establecan controles preventivos que se anticipan incluso al umbral de riesgo estabelecido por el legislador, pese a que puedan ser de nueva creación y originales, en nada influyen sobre el Derecho penal, al igual que declaraciones principialistas o éticas.". COCA VILA, Ivó. op. cit., p. 70.

${ }^{608}$ Para um maior detalhamento do conceito de autorregulação, ver capítulo primeiro, item 1.5.3.

${ }^{609}$ Não se pode negar, nesse ponto, que COCA VILA é coerente, na medida em que nega efeitos quer sobre o Direito Penal, quer sobre o Direito Administrativo Sancionador, aos sistemas normativos privados. Afirma ele: "Un modelo com el previsto, y que algunos autores, con mayor o menor rotundidad patrocinan, careceria de la necesaria legitimación, pues el Derecho penal no puede resistir en modo alguno su integración directa a partir de sistemas normativos privados. El Derecho penal es por definición público, emana y sólo pude emanar del Estado, legitimable materialmente en tanto que sirve a los intereses generales y cuyas decisiones son fruto de la decisión de la mayoría de los miembros a las que se dirigen. [...] De hecho, no creo ni tan siquiera que sea susceptible de legitimación un sistema sancionatório administrativo en el que la realización de las infracciones y su castigo dependa de sistemas regulativos privados, al menos, tal y como se ha configurado el papel del Estado en los processos de autorregulación en nuestro Código Penal.”. COCA VILA, Ivó. op. cit., p. 69.
} 
culpabilidade de forma a concretizar seu caráter garantísitco de limitação do exercício punitivo pelo Estado. Para tanto, faz-se necessário reconhecer em tais programas uma capacidade exoneratória de responsabilidade, não o limitando a efeitos atenuantes da sanção. Ao que se pensa, aliás, esse é o modo de se consagrar, nesse campo, a autorregulação como estratégia estatal.

Por fim, interessante constatar que tal raciocínio é aplicável não só a uma responsabilidade penal da pessoa jurídica, como também a eventual responsabilidade administrativa. 


\section{CONCLUSÕES}

1. A responsabilidade penal da pessoa jurídica, apesar de não ser uma inovação na história do direito, é tema que abre espaço ao embate entre dogmática e política criminal, sobretudo porque a teoria do delito se desenvolveu voltada à pessoa humana, demonstrando sua incompatibilidade com este "novo" sujeito do Direito Penal.

2. Entre as objeções dogmáticas à responsabilidade penal da pessoa jurídica, sobressai a culpabilidade pelo substrato psicológico que contém e que seria incompatível com o ente coletivo, em face do seu déficit de subjetividade.

3. A dogmática, contudo, não é um fim em si mesmo. É produto histórico, devendo, portanto, ser compatibilizada com as demandas da sociedade, observando-se, é claro, os limites estabelecidos nos direitos humanos fundamentais.

4. Há uma demanda político-criminal pela responsabilidade penal da pessoa jurídica, fundada, especialmente, no reconhecimento de tal ente como protagonista nas relações sociais, dententor de conhecimentos técnico-científicos e com uma atuação territorialmente difusa, características estas que tornam a regulação estatal interventiva deficiente.

5. Diante de tais características, o Estado deve recorrer a uma estratégia regulatória diferenciada, qual seja, a autorregulação, instrumentalizando as normas privadas em função dos objetivos públicos de controle de riscos.

6. Neste sentido, a responsabilidade penal da pessoa jurídica é instrumento de motivação coativa da auto-organização empresarial que funcionará como complemento de outros setores de fomento à autorregulação, como o Direito Administrativo. O Direito Penal deve atuar, então, como ultima ratio da autorregulação regulada.

7. No desafio de se compatibilizar dogmaticamente a responsabilidade penal da pessoa jurídica com a culpabilidade, deve-se observar, em primeiro lugar, que a culpabilidade, como construção voltada para a pessoa física, já apresenta dificuldades em sua definição, não evidenciando um conceito unívoco, sobressaindo, neste aspecto, a desafio de se alcançar uma fundamentação material dessa culpabilidade.

8. Percebe-se, nas contruções relacionadas à culpabilidade individual, a grande utilização de categorias socais para fundamentar os parâmetros ficcionais (de difícil demonstração) sobre os quais se tem construído o conceito. 
9. Nesse sentido, pode-se se dizer que o substrato psicológico da culpabilidade tem se apoiado nas categorias sociais para superar sua indemonstrabilidade, revelando um encaminhamento do conceito para considerações relacionadas ao compromisso com a alteridade e a preocupações relativas à solidariedade.

10. Há uma busca, nas teorias contemporâneas de culpabilidade individual, de responder às exigências de política criminal e a demandas sociais de estabilização.

11. A análise apenas dos debates teóricos relacionados à culpabilidade individual permite-nos constatar que as alterações dogmáticas são inerentes à evolução do Direito Penal como ciência humana, de forma que o questionamento sobre tais modificações não é inaugurado pela admissão da responsabilidade penal da pessoa jurídica. Assim, redefinições estruturais não necessariamente configuram o abandono ou desvirtuamento da culpabilidade.

12. O desafio que se coloca, tanto para a culpabilidade individual como da pessoa jurídica, é alcançar um conceito que responda adequadamente às exigências que lhe são feitas.

13. O conceito de culpabilidade, em sua evolução, parece apontar como exigência principal o não abandono de seu caráter de garantia, no sentido de ser critério apto a limitar o exercício punitivo pelo Estado.

14. Bem por isso, a culpabilidade deve ser encarada sem preconceitos, desapegada dos dogmas estruturais, mais com apoio nos fundamentos principiológicos básicos do Direito Penal, em especial a dignidade da pessoa humana e a limitação do poder punitivo estatal.

15. De outro lado, constata-se que o problema da distinção entre juízo de valoração e objeto, percebido nas teorias da culpabilidade da pessoa física, é a pedra de toque na construção de uma culpabilidade da pessoa jurídica.

16. Pode-se afirmar que o juízo de imputação subjetiva no âmbito individual parece, em alguns aspectos, se aproximar dos questionamentos atrelados à culpabilidade da pessoa jurídica.

17. Além da função de limitação do exercício punitivo pelo Estado, a busca de se adequar um conceito de culpabilidade à responsabilidade penal da pessoa jurídica tem o significado de demonstrar que se trata do exercício de um poder de punir válido. 
18. Para uma adequada análise das construções teóricas de uma culpabilidade empresarial, deve-se ter em conta que as limitações constitucionais relacionadas ao princípio da culpabilidade estão ligadas estritamente à pessoa humana e, neste aspecto, não podem ser endereçadas à pessoa jurídica. Isto, contudo, não deve servir para justificar a possibilidade de uma responsabilidade penal da pessoa jurídica sem culpabilidade, mas sim para indicar que a interpretação do conteúdo dessa culpabilidade não pode se apegar aos mesmos princípios e garantias relacionadas aos indivíduos.

19. Bem por isso, entende-se que não se pode objetar construções como “culpabilidade pelo caráter", ou qualquer outra baseada em aspectos do direito penal do autor quando aplicadas à pessoa jurídica, com fundamento nas críticas empreendidas a esses conceitos relacionadas aos princípios e garantias voltados à pessoa humana.

20. Na culpabilidade relacionada à pessoa jurídica, deve sobressair no conceito sua função de limitação do poder punitivo estatal. Desse modo, pensa-se que todas as construções teóricas atinentes à culpabilidade da pessoa jurídica ou conceito equivalente devem ser valoradas consoante a capacidade de exercerem tal função, melhor identificada como a capacidade de verificar causas de exclusão da responsabilidade penal.

21. Outra característica que não pode ser olvidada num conceito de culpabilidade empresarial é sua peculiar dimensão temporal. Essa avaliação deve considerar aspectos pré e pós-delitivos e não necessariamente coincidirá com o tempo da ação danosa ou perigosa desaprovada.

22. Pode-se perceber, na análise das diversas construções teóricas de uma culpabilidade da pessoa jurídica, inclusive nos posicionamentos críticos à existência de tal culpabilidade, a prevalência do defeito organizativo como critério a ser ponderado na responsabilização (ainda que não penal) da pessoa jurídica, o que demonstra que a tentativa de se delinear esse defeito de organização será importante para além dos limites de uma responsabilidade de caráter criminal.

23. Constata-se, também, a inserção de critérios éticos (como a valoração de uma cultura empresarial ou de uma filosofia da empresa) na avaliação relacionada à culpabilidade.

24. Pensa-se, contudo, ser mais adequado congregar a consideração desses dois aspectos (organizativo e ético) num conceito mais amplo de defeito organizativo, que se 
voltará não só à definição estrutural da empresa, como também à transmissão de informações e valores em seu bojo.

25. É possível constatar uma relação entre os programas de compliance e as construções teóricas de culpabilidade que se estabelece tanto em relação ao seu conteúdo, como em relação à sua função.

26. Em relação ao conteúdo, deve-se dizer que os programas de compliance trazem a lume medidas de organização empresarial voltadas à prevenção de riscos, organização esta que deve ser tomada em sua acepção mais ampla, incluindo não só aspectos estruturais, como também éticos, entendidos como a promoção de uma responsabilidade social da empresa (inclusive com a fixação de pautas de atuação em aspectos não regulados pela lei) e considerações sobre a influência do ambiente empresarial na conduta dos integrantes do ente coletivo.

27. A incorporação desses aspectos éticos não só conecta os programas de compliance ao conteúdo de uma culpabilidade empresarial entendida como defeito organizativo lato sensu, como também permite reconhecê-los como expressão da autorregulação, ao não se limitarem à positivação, no bojo empresarial, de medidas necessárias para atuar em conformidade com o direito já dado. Ou seja, a possibilidade de definição de uma regulação privada além dos aspectos já regulados pela lei permite reconhecer um poder configurador jurídico da empresa.

28. De outro lado, em relação à função, os programas de compliance, como parâmetro a ser observado pelo julgador no momento de avaliar a eficácia das medidas de organização empresarial, devem poder incidir como causas de exoneração da responsabilidade penal. Neste sentido, não pode haver uma relação de necessidade entre o advento da prática delitiva no bojo empresarial e a responsabilização do ente coletivo. Adotadas medidas razoáveis de controle de riscos no bojo empresarial e verificado que o delito não decorre de uma deficiência da "filosofia empresarial", no sentido de se fomentar os objetivos de lucro (por exemplo) sem limitações éticas para o seu alcance, não se pode responsabilizar a empresa pelo advento do delito, para que a responsabilidade penal não se converta em responsabilidade objetiva.

29. Nesse sentido, percebe-se uma tendência legislativa (ou prática, como no caso americano) de reconhecimento da adoção de programas de compliance adequados como causa de exoneração da responsabilidade penal da pessoa jurídica. 
30. A legislação brasileira ainda se apresenta de forma muito incipiente no tema dos programas de compliance e sua relação com a responsabilidade da pessoa jurídica. No específico aspecto da responsabilidade penal (Lei 9.605/98), não há menção a qualquer elemento que permita relacionar tal responsabilização com os programas de compliance ou mesmo com a apuração de defeitos organizativos. Eventual questionamento atinente a tais aspectos só poderia se dar por meio de uma teria do crime afeta a este peculiar sujeito penal, de forma que a construção de um conceito de culpabilidade empresarial seria de extrema relevância para tal função, limitando de forma mais adequada o exercício punitivo estatal.

31. Essa constatação permite reafirmar que um modelo de responsabilidade penal não necessariamente deve estar relacionado a um modelo de apuração de culpabilidade. No caso da Lei 9.605/98, é possível tentar relacionar o modelo vicarial de responsabilidade com a apuração de uma culpabilidade própria da pessoa jurídica, apesar de não se negar as dificuldades de se concretizar essa compatibilização.

32. Observe-se, por outro lado, que a Lei 12.846/2013, conquanto trate da responsabilidade civil e administrativa da pessoa jurídica, contribui para o tema em análise ao possibilitar questionamentos sobre os efeitos da aplicação de modelos de prevenção sobre a responsabilidade do ente coletivo. O fomento à adoção de mecanismo de integridade e auditoria, de códigos de ética e conduta, bem como à denúncia de constatação de irregularidades (aspectos intimamente ligados à ideia de defeito organizativo e ao conteúdo mínimo dos programas de compliance) é efetuado pela lei com a atenuação da sanção. É questionável, contudo, a utilização legal de uma responsabilidade administrativa objetiva, o emprego de termos vagos, bem como a inexistência de formas de isenção da responsabilidade pela adoção dessas medidas, o que pode implicar numa estratégia de autorregulação deficiente.

33. É perceptível, então, que as consideração relativas à definição de culpabilidade empresarial (que nos pareceu mais adequadamente relacionada - ainda que não perfeita - à ideia de defeito organizativo em sentido amplo) e aos programas de compliance terão importância não só para aqueles que defendem a responsabilidade penal da pessoa jurídica, como também para os partidários de uma responsabilidade administrativa, observando-se a necessidade de limitação do exercício do poder punitivo estatal nestes dois âmbitos e de fomento eficiente da autorregulação. 
34. Deve-se consignar, contudo, que por mais que as construções teóricas de culpabilidade empresarial venham se refinando (ligando-se, em algunas casos, até mesmo à inserção de novos paradigmas no Direito Penal, como as considerações atinentes aos sistemas de injusto e injusto de sistemas), não conseguiram superar todas as críticas empreendidas. E, nesse sentido, sobressai a dificuldade de se distinguir a culpabilidade do próprio injusto, que nos remete, ao que se pensa, ao desafio já identificado de se diferenciar o juízo de valoração de seu objeto.

35. Mesmo constatada essa dificuldade ainda não superada, entende-se inadequada a inserção de um raciocínio compensatório na responsabilidade da pessoa jurídica. O objetivo da responsabilização, quer administrativa, quer penal, não pode ser identificado com a neutralização de um enriquecimento ilícito. Ainda que a constatação de uma vantagem experimentada pela empresa como consequência da prática delitiva em seu bojo possa constituir requisito para a responsabilização, crê-se que a intervenção patrimonial, conquanto seja consequência da aplicação da sanção, não constitui seu objetivo. A responsabilização da pessoa jurídica, por qualquer modalidade que seja, deve expressar a finalidade de fomento à autorregulação eficiente como forma mais adequada de prevenir riscos da atividade empresarial. 


\section{REFERÊNCIAS BIBLIOGRÁFICAS}

ABANTO VASQUEZ, Manuel A. El llamado derecho penal del enemigo. Especial referencia al derecho penal económico. In: CANCIO MELIÁ, Manuel; GÓMEZ-JARA DÍEZ, Carlos (coord.). Derecho Penal del Enemigo. El discurso penal de la exclusión. Buenos Aires: Edisofer, 2006.

ABOSO, Gustavo Eduardo; ABRALDES, Sandro Fabio. Responsabilidad de las personas jurídicas en el derecho penal comparado. Buenos Aires: Editorial B de F, 2000.

ALCÁCER GUIRAO, Rafael. Cumplimiento penal por la persona jurídica y derechos fundamentales: la intimidad como limite a la vigilância empresarial. Diario La Ley, $\mathrm{n}^{\circ}$ 8053, Sección Doctrina, ano XXXIV, 2 abr. 2013. Disponível em:<http://diariolaley.laley.es $>$. Acesso em: 6 jun. 2013.

BACHMAIER WINTER, Lorena. Responsabilidad penal de las personas jurídicas: definición y elementos de un programa de compliance. Diario La Ley, n. 7398, Sección Tribuna, 5 oct. 2012. Disponível em: <http://www.diariolaley.laley.es>. Acesso em: 05 jun. 2013.

BACIGALUPO, Silvina. La responsabilidad penal de las personas jurídicas. Barcelona: Bosch, 1998.

. Los criterios de imputación de la responsabilidad penal de las empresas y de sus órganos de gobierno y la relevância de los programas de compliance en el código penal español (artículos 31 bis y 129 CP). Revista de Estudos Criminais, ano X, no 42, jul.-set. 2011.

BACIGALUPO ZAPATER, Enrique. "Compliance” y derecho penal: prevención de la responsabilidade de directivos y de empresas. Buenos Aires: Hammurabi, 2012.

BAIGÚN, David. La responsabilidad penal de las personas jurídicas: ensayo de um nuevo 
modelo teórico. Buenos Aires: Depalma, 2000.

BAJO FERNÁNDEZ, Miguel. La responsabilidad penal de las personas jurídicas en el derecho administrativo español. In: MIR PUIG, Santiago; LUZÓN PEÑA, Diego Manuel (coord.). La responsabilidad penal de las empresas y sus órganos y responsabilidad por el producto. Barcelona: J.M. Bosch, 1996.

BAJO FERNÁNDEZ, Miguel; BACIGALUPO, Silvina. Derecho penal económico. Madrid: Centro de Estudios Ramón Areces, 2001.

BASTOS, Celso Ribeiro; MARTINS, Ives Gandra. Comentário à Constituição do Brasil. São Paulo: Saraiva, 1990.

BETTIOL, Giuseppe. O problema penal. Trad. Fernando de Miranda. Coimbra: Coimbra Editores, 1967.

BIBLIOTECA DEL CONGRESO NACIONAL DE CHILE. Historia de la Ley $n^{o} 20.393$, p. 248. em: <http://www.leychile.cl/Consulta/portada_hl?tipo_norma=XXI\&nro_ley=20.393\&anio=20 13>. Acesso em: 09 jul. 2013.

BITTENCOURT, Cezar Roberto. Responsabilidade penal da pessoa jurídica à luz da Constituição Federal. Boletim IBCCRIM, nº 65 ed. esp., abr. 1998.

BRASIL. Ministério da Justiça. Secretaria de Assuntos Legislativos. Série Pensando o Direito: responsabilidade penal da pessoa jurídica. n. 18, 2009. p. 31. Disponível em: <portal.mj.gov.br/main.asp?view=\{329D6EB2-8AB0-4606-B054-4CAD3C53EE73\}>. Acesso em: 15 jul. 2011.

BRAVO, Jorge dos Reis. Direito Penal de Entes Colectivos: Ensaio sobre a punibilidade de pessoas colectivas e entidades equiparadas. Coimbra: Coimbra Editores, 2008.

BREDA, Juliano. Inconstitucionalidade das sanções penais da pessoa jurídica. In: 
PRADO, Luiz Regis; DOTTI, René Ariel (coord.). Responsabilidade penal da pessoa jurídica: Em defesa do princípio da imputação subjetiva. 2.ed. São Paulo: Revista dos Tribunais, 2010.

CALLEGARI, Andre Luís. Compliance no Brasil: a necessidade da quebra de conceitos equivocados acerca da cultura da conformidade. Disponível em: $<$ http://lecnews.com/novo/compliance-no-brasil-a-necessidade-da-quebra-de-conceitosequivocados-acerca-da-cultura-da-conformidade/>. Acesso em: 31 out. 2013.

CARBÓNELL MATEU, Juan Carlos; MORALES PRATS, Fermín. Responsabilidad penal de las personas jurídicas. In: ÁLVAREZ GARCÍA, Francisco Javier. GONZÁLEZ CUSSAC, José Luiz. Comentarios a la Reforma Penal de 2010. Valencia: Tirant lo Blanch, 2010.

CARVAlHO, Érika Mendes de; CARVALHO, Gisele Mendes de. Direito Penal de risco e responsabilidade penal das pessoas jurídicas. In: PRADO, Luiz Regis; DOTTI, René Ariel (coord.). Responsabilidade penal da pessoa jurídica: Em defesa do princípio da imputação subjetiva. 2.ed. São Paulo: Revista dos Tribunais, 2010.

CASTRO E SOUSA, João. As pessoas colectivas em face do direito criminal e do chamado "direito de mera ordenação social”. Coimbra: Coimbra Editores, 1985.

CEREZO MIR, José. Culpabilidad y pena. In: Anuario de Derecho Penal y Ciencias Penales. tomo XXXIV, fasc. II. Madrid: Ministerio da Justicia-Boletín Oficial del Estado, 1980.

CERNICCHIARO, Luiz Vicente; COSTA JÚNIOR, Paulo José da. Direito Penal na Constituição. São Paulo: Revista dos Tribunais, 1995.

CHAVES CAMARGO, Antonio Luis. Culpabilidade e reprovação penal. São Paulo: [s.n.], 1993.

Imputação objetiva e direito penal brasileiro. São Paulo: Cultural Paulista, 2002. 
COBO DEL ROSAL, Manuel; VIVES ANTÓN, Tomás S. Derecho penal: parte general. Valencia: Tirant lo Blanch, 1990.

COCA VILA, Ivó. ¿Programas de cumplimiento como forma de autorregulación regulada?. In: SILVA SÁNCHEZ, Jesús-María (dir.); MONTANER FERNÁNDEZ, Raquel (coord.). Criminalidad de empresa y Compliance. Barcelona: Atelier, 2013.

COELHO, Fabio Ulhôa. Manual de Direito Comercial. 22.ed. São Paulo: Saraiva, 2010.

CONSTANTINO, Carlos Ernani. O art. $3^{\circ}$ da Lei n. 9605/98 cria intolerável bis in idem. Boletim IBCCRIM, n 72 , nov. 1998.

Outros aspectos da responsabilidade da pessoa jurídica. Boletim IBCCRIM, $\mathrm{n}^{\circ} 74$, jan. 1999

DE LA MATA BARRANCO, Norberto Javier; BILBAO LORENTE, Martín; ALGORTA BORDA, Mariana. La atribuición de responsabilidade penal de las personas jurídicas y su exención: instrumentos de prevención en el seno corporativo. La Ley Penal, n. 87, nov. 2011.

DEL ROSAL BLASCO, Bernardo. Responsabilidad penal de empresas y códigos de buena conducta corporativa. Diario La Ley, ano XXXI, n. 7670, Sección Doctrina, 11 jul. 2011. Disponível em: <http://www.laley.com.br>. Acesso em: 06 jun. 2013.

DOHNA, Alexander Graf zu. La estructura de la teoria del delito. Trad. Carlos Fontán Balestra e Eduardo Friker. Buenos Aires: Abedelo-Perrot, 1958.

DÍEZ RIPOLLÉS, José Luis. La responsabilidad penal de las personas jurídicas. Regulación española. InDret, n.1, jan. 2012.

DOTTI, René Ariel. A incapacidade criminal da pessoa jurídica (Uma perspectiva do direito brasileiro). In: PRADO, Luiz Regis; DOTTI, René Ariel (coord.). Responsabilidade 
penal da pessoa jurídica: Em defesa do princípio da imputação subjetiva. 2.ed. São Paulo: Revista dos Tribunais, 2010.

FEIJÓO SÁNCHEZ, Bernardo. Autoria e participação em organizações empresariais complexas. Trad. Vania Costa Ramos. Revista Liberdades, n. 9, jan.-abr. 2012.

Cuestiones Básicas sobre la responsabilidad penal de las personas jurídicas, de otras personas morales y de agrupaciones y asociaciones de personas. In: FRANCO, Alberto Silva; NUCCI, Guilherme de Souza (org.). Doutrinas Essenciais: Direito Penal. v. 3, Parte Geral 2. São Paulo: Revista dos Tribunais, 2010.

- La persona jurídica como sujeto de imputación jurídico penal. In: BAJO FERNÁNDEZ, Miguel; et alli. Tratado de responsabilidad penal de las personas jurídicas. Pamplona: Civitas, 2012.

Sanciones para empresas por delitos contra el medio ambiente: presupuestos dogmáticos y criterios de imputación para la intervención del Derecho Penal contra las empresas. Madrid: Civitas, 2002.

FERRAJOLI, Luigi, Derecho y razón: teoría del garantismo penal. 8 ed. Madrid: Trotta, 2006.

FIGUEIREDO DIAS, Jorge de. Liberdade, culpa e direito penal. Coimbra: Coimbra Editores, 1995.

FISSE, Brent. BRAITHWAITE, John. Corporates, crime and accountability. Cambridge: Cambridge University Press, 1993.

FOFFANI, Luigi. Bases para una imputación subjetiva de la persona moral: ¿Hacia una culpabilidad de las personas jurídicas?. In: Dogmática penal del tercer milenio: libro homenaje a los profesores Eugenio Raul Zaffaroni y Klaus Tiedemann. Lima: Ara, 2008.

FRANCO, Affonso Arinos de Mello. Responsabilidade criminal das pessôas jurídicas. Rio de Janeiro: Gráphica Ypiranga, 1930. 
FREITAS, Vladimir Passos de. O crime ambiental e a pessoa jurídica. Cidadania e Justiça, v. 3, no 6, jan.-jun.1999.

GALLAS, Wilhelm. La teoria do delito en su momento actual. Trad. Juan Córdoba Roda. Barcelona: Bosch, 1959.

GARCÍA CAVERO, Percy. La persona jurídica como sujeto penalmente responsable. In: YACOBUCCI, Guillermo J. (dir.). Derecho penal empresário. Montevidéu: B. de F., 2010.

GARCIA-PABLOS DE MOLINA, Antonio. Derecho penal: introducción. Madrid: Universidad Complutense - Servicio de Publicaciones, 1995.

GÓMEZ-JARA DÍEZ, Carlos. La culpabilidad de la persona jurídica. In: BAJO FERNÀNDEZ, Miguel; FEIJOO SÀNCHEZ, Bernardo José; GÓMEZ-JARA DÍEZ, Carlos. Tratado de responsabilidade penal de las personas jurídicas, Navarra: Aranzandi, 2012.

La culpabilidad penal de la empresa. Madrid: Marcial Pons, 2005.

La responsabilidade penal de las personas jurídicas: el modelo constructivista de autorresponsabilidad penal empresarial. Lima: Ara, 2010.

GONZÁLEZ FRANCO, J.A.; SCHEMMEL, A.; BLUMENBERG, A. La función del penalista en la confección, implementación y evaluación de los programas de cumplimiento. In: ARROYO ZAPATERO, Luis; NIETO MARTÍN, Adan (dir.). El derecho penal económico en la era compliance. Valencia: Tirant lo blanch, 2013.

GRACIA MARTÍN, Luis. Instrumentos de imputación jurídico penal en la criminalidad de empresa e reforma penal. In: Actualidad penal. 1/26, v.1, 1993.

GRECO, Luis. Introdução à dogmática funcionalista do delito: em comemoração aos trinta anos de "Política criminal e sistema jurídico-penal" de Roxin. In: Revista Brasileira de 
Ciências Criminais. n. 32, v. 8, 2000.

HEFENDEHL, Roland. La responsabilidad penal corporativa: Artículo 2.07 del Código Penal modelo y el desarrollo em los sistemas legales occidentales. In: REYNA ALFARO, Luis Miguel (coord.). Nuevas tendencias del derecho penal económico y de la empresa. Lima: Ara Editores, 2005.

HEINE, Günther. La responsabilidad penal de las empresas: evolución y consecuencias nacionales.Trad. Aldo Figueroa Navarro e José Hurtado Pozzo. In: HURTADO POZO, José; DEL ROSAL BLASCO, Bernardo; SIMONS VALLEJO, Rafael. La responsabilidad criminal de las personas jurídicas: uma perspectiva comparada. Valência: Tirant lo blanch, 2001.

HERNÁNDEZ, Hector. La introducción de la responsabilidad penal de las personas jurídica en Chile. Política Criminal, v. 5, n. 9, jul. 2010. Disponível em: <http://politicacriminal.cl/Vol_05/n_09/Vol5N9A5.pdf>. Acesso em: 12 nov. 2012.

JAKOBS, Günther. Derecho Penal: Parte General. Fundamentos y teoria de la imputación. 2. ed. Tradução Joaquin Cuello Contrera e José Luis Serrano Gonzales de Murillo. Madrid: Marcial Pons, 1997.

La culpabilidad de los foráneos. In: CANCIO MELIÁ, Manuel, FEIJOO SÁNCHEZ, Bernardo (ed.). Teoría funcional de la pena y culpabilidad. Pamplona: Aranzadi, 2008.

Punibilidad de las personas jurídicas. In: El funcionalismo en derecho penal. Libro homenaje al profesor Günther Jakobs. v. I. Bogotá: Universidad Externado de Colombia, 2003.

Sobre la normativización de la dogmática jurídico-penal. Trad. Manuel Cancio Meliá e Bernardo Feijóo Sánchez. Madrid: Civitas, 2003. 
JESCHECK, Hans-Heinrich. Evolução do conceito jurídico penal de culpabilidade na Alemanha e na Áustria. Trad. Patrícia Esquinas Valverde. Revista Electrónica de Ciencia Penal y Criminologia, $\mathrm{n}^{\mathrm{o}}$ 5, 2003. Disponível em: <http://criminet.ugr.es/recpc/05/recpc0501.pdf>. Acesso em: 24 maio 2012.

Tratado de derecho penal: parte general. 4 ed. Trad. José Luiz Mazanares Samaniego: Comares, 1993.

KINDHÄUSER, Urs. La fidelidad al derecho como categoria de la culpabilidad. In: FRANCO, Alberto Silva; NUCCI, Guilherme de Souza. Doutrinas Essenciais: Direito Penal, v. 3, Parte Geral 2. São Paulo: Revista dos Tribunais, 2010.

LAMY FILHO, Alfredo; PEDREIRA, José Luiz (coord.), Direito das Companhias. v. 1. Rio de Janeiro, Forense, 2009.

LAMPE, Ernst-Joachim. La dogmática jurídico-penal entre la ontología social y el funcionalismo. Trad. Carlos Gómez-Jara Díez; Guillermo Orce e Miguel Polaino Orts. Lima: Grijley, 2003.

LOBO DA COSTA, Helena Regina. Proteção penal ambiental: viabilidade, efetividade, tutela por outros ramos do direito. São Paulo: Saraiva, 2010.

LUISI, Luiz. Notas sobre a responsabilidade penal das pessoas jurídicas. In: PRADO, Luiz Regis; DOTTI, René Ariel (coord.). Responsabilidade penal da pessoa jurídica: Em defesa do princípio da imputação subjetiva. 2.ed. São Paulo: Revista dos Tribunais, 2010.

MACHADO, Fabio Guedes de Paula. Culpabilidade no direito penal. São Paulo: Quartier Latin, 2010.

. Reminiscências da responsabilidade penal da pessoa jurídica. In: FRANCO, Alberto Silva; NUCCI, Guilherme de Souza (org.). Doutrinas essenciais: Direito Penal. v. 3. Parte Geral 2, São Paulo: Revista dos Tribunais, 2010. 
MAROTO CALATAYUD, Manuel. Liberalismo versus neocorporativismo: los discursos de la autorregulación como discursos legitimantes. In: ZAPATERO, Luis Arroyo; LASCANO, Carlos; NIETO MARTíN, Adán (dir.). Derecho penal de la empresa. Buenos Aires: Ediar, 2012.

MARQUES, Oswaldo Henrique Duek. A responsabilidade da pessoa jurídica por ofensa ao meio ambiente. Boletim IBCCRIM, $\mathrm{n}^{\circ} 65$ ed. esp., abr. 1998.

MATUS ACUÑA, Jean Pierre. La certificación de los programas de cumplimiento. In: ARROYO ZAPATERO, Luis; NIETO MARTÍN, Adan (dir.). El derecho penal económico en la era compliance. Valencia: Tirant lo blanch, 2013.

MAURACH, Reinhart. Tratado de derecho penal. v. 2. Trad. Juan Córdoba Roda. Barcelona: Ediciones Ariel, 1962.

MIR PUIG, Santiago. Direito penal: fundamentos e teoría do delito. Tradução José Carlos Nobre Porciúncula Neto. São Paulo: Revista dos Tribunais, 2007.

MORALES ROMERO, Marta Muñoz de. Programas de cumplimiento "efectivos" en la experiência comparada. In: ARROYO ZAPATERO, Luis; NIETO MARTÍN, Adan (dir.). El derecho penal económico en la era compliance. Valencia: Tirant lo blanch, 2013.

NIETO MARTÍN, Adan. La responsabilidad penal de las personas jurídicas: un modelo legislativo. Madrid: Iustel, 2008.

NUNES, Marcelo Guedes. A Companhia, A Especulação e o Capitalismo Moderno: fazendo curta uma história longa. In: CASTRO, Rodrigo R. Monteiro; ARAGÃO, Leandro Santos de. Sociedade Anônima: 30 anos da Lei 6.404/76. São Paulo, Quartier Latin, 2007.

ORCE, Guillermo. Responsabilidad penal de las personas jurídicas. In: El funcionalismo en derecho penal. Libro homenaje al profesor Günther Jakobs. v. II. Colombia: Univerisdad Externado de Colombia, 2003. 
ORTIZ DE URBINA GIMENO, Iñigo. Responsabilidad penal de las personas jurídicas y programas de cumplimiento empresarial (“compliance programs"). In: GOÑI SEIN, José Luis (dir.). Ética empresarial y código de conducta. Las Rozas, Madrid: La Ley, 2011.

PADOVANI, Tullio. Teoria della colpevolezza e scopi della pena. Rivista Italiana di Diritto e procesdura penale. anno XXX. Milano: Dott. A. Giuffrè Editore, 1987.

PASTOR MUÑOZ, Nuria. ¿Organizaciones culpables? Recensión a Carlos Gómez-Jara, La culpabilidad penal de la empresa. InDret. Barcelona: 2006. Disponível em: <http://www.indret.com/pdf/340.pdf>. Acesso em: 17 maio 2012.

PEREIRA, Caio Mário da Silva. Instituições de direito civil. v. 1. Rio de Janeiro: Forense, 1978.

PIERANGELI, José Henrique. Escritos Jurídico-Penais, São Paulo: Revista dos Tribunais, 2006.

PITOMBO, Antonio Sergio Altieri de Moraes. Denúncia em face da pessoa jurídica, na perspectiva do direito brasileiro. In: PRADO, Luiz Regis; DOTTI, René Ariel (coord.). Responsabilidade penal da pessoa jurídica: Em defesa do princípio da imputação subjetiva. 2.ed. São Paulo: Revista dos Tribunais, 2010.

PRADO, Luiz Regis. Responsabilidade penal da pessoa jurídica: fundamentos e implicações. In: PRADO, Luiz Regis; DOTTI, René Ariel (coord.). Responsabilidade penal da pessoa jurídica: Em defesa do princípio da imputação subjetiva. 2.ed. São Paulo: Revista dos Tribunais, 2010.

QUINTANO RIPPOLLÉS, Antonio. Hacia una posible concepción unitária jurídico-penal de la culpabilidad. Anuario de Derecho Penal. tomo XII, fasc. II. Madrid: Ministerio de Justicia, Boletín Oficial del Estado, 1950.

REALE JÚNIOR, Miguel. A responsabilidade penal da pessoa jurídica. In: PRADO, Luis Régis,. DOTTI, René Ariel (coord.). Responsabilidade penal da pessoa jurídica: Em defesa do princípio da imputação subjetiva. 2.ed. São Paulo: Revista dos Tribunais, 2010. 
REQUIÃO, Rubens. Curso de direito comercial. v.1. São Paulo: Saraiva, 2003.

RIOS, Rodrigo Sanchez. Indagações sobre a possibilidade da imputação penal à pessoa jurídica no âmbito dos delitos econômico. In: REGIS PRADO, Luiz; DOTTI, René Ariel (coord.). Responsabilidade penal da pessoa jurídica: Em defesa do princípio da imputação subjetiva. 2.ed. São Paulo: Revista dos Tribunais, 2010.

ROBALDO, José Carlos de Oliveira. A responsabilidade penal da pessoa jurídica: direito penal na contramão da história. In: GOMES, Luiz Flávio. Responsabilidade Penal da Pessoa Jurídica e Medidas Provisórias de Direito Penal, São Paulo: RT, 1999.

ROBLES PLANAS, Ricardo. ¿Delitos de personas jurídicas? A propósito de la Ley austríaca de responsabilidade de las agrupaciones por hechos delictivos. InDret, $\mathrm{n}^{\circ} \mathbf{2}$, abr. 2006. Disponível em: <http://www.indret.com>. Acesso em: 06 jun. 2013.

. El "hecho propio" de las personas jurídicas y el Informe del Consejo General del Poder Judicial al Anteproyecto de Reforma del Código penal de 2008. InDret, n², abr. 2009. Disponível em: <http://www.indret.com>. Acesso em: 06.06.2013.

Pena y persona jurídica: crítica del articulo 31 bis CP. Diario La Ley, $\mathrm{n}^{\circ} 7705$, set. 2011.

ROJAS A. Luis Emilio. Ley 20393 de la República de Chile sobre responsabilidad penal de las personas jurídicas. Revista de Derecho Penal y Procesal Penal, nº 5, mai. 2012.

ROSO CAÑADILLAS, Raquel. Las fuentes de imputación de la responsabilidad penal corporativa. La Ley Penal: Revista de Derecho Penal, procesal y penitenciário, n. 81, abr. 2011.

ROTH, Roberth. Responsabilidad penal de la empresa: modelos de reflexión. In: HURTADO POZO, José; DEL ROSAL BLASCO, Bernardo; SIMONS VALLEJO, Rafael. La responsabilidad criminal de las personas jurídicas: una perspectiva comparada. 
Valência: Tirant lo blanch, 2001.

ROTSCH, Thomas. Criminal compliance. InDret, n. 1, ene. 2012. Disponível em: <http://indret.com/pdf/876a.pdf>. Acesso em: 05 jun. 2013.

RODRÍGUEZ RAMOS, Luis. Nuevos aspectos dogmáticos y procesales del principio "societas delinquere non potest". In: HURTADO POZO, José; DEL ROSAL BLASCO, Bernardo; SIMONS VALLEJO, Rafael. La responsabilidad criminal de las personas jurídicas: una perspectiva comparada. Valência: Tirant lo blanch, 2001.

ROXIN, Claus. A culpabilidade e sua exclusão no direito penal. Revista Brasileira de Ciências Criminais. São Paulo, v. 12, f. 46, (jan.-fev. 2004).

Culpabilidad y prevención en derecho penal. Trad. Francisco Muñoz Conde. Madrid: Reus, 1981.

. Derecho Penal: Parte General. Trad. Diego-Manuel Luzón Pena, Miguel Díaz y García Conlledo, Javier de Viente Remesal. Madrid: Civitas, 2001.

RUIZ RENGIFO, Hoover Wadith. La responsabilidad penal de las personas jurídicas. Una tarea inconclusa en España y Colombia. Salamanca: Ratio Legis, 2012.

SANTOS, Juarez Cirino dos. Responsabilidade penal da pessoa jurídica. In: PRADO, Luiz Regis; DOTTI, René Ariel (coord.). Responsabilidade penal da pessoa jurídica: Em defesa do princípio da imputação subjetiva. 2.ed. São Paulo: Revista dos Tribunais, 2010.

SALLES, Sheila Jorge Selim. Princípio 'societas delinquere non potest' no direito penal moderno. In: PRADO, Luiz Regis; DOTTI, René Ariel (coord.). Responsabilidade penal da pessoa jurídica: Em defesa do princípio da imputação subjetiva. 2.ed. São Paulo: Revista dos Tribunais, 2010.

SEL, Juan María del. Societas delinquere, ¿potest o non potest? La responsabilidad criminal de la empresa a la luz de la visión anglosajona. In: YACOBUCCI, Guillermo J. 
(dir.). Derecho penal empresário. Montevidéu: B. de F., 2010.

SCHÜNEMANN, Bernd. La culpabilidad: estado de la cuestión. Trad. David Felip I Saborit y Ramón Ragués I Vallés. In: ROXIN, Claus et al. Sobre el estado de la teoría del delito: Seminario en la Universitat Pompeu Fabra. Madrid: Civitas, 2000.

SHECAIRA, Sérgio Salomão. A responsabilidade das pessoas jurídicas e os delitos ambientais. Boletim do IBCCRIM, nº 65, abr.1998.

Responsabilidade penal da pessoa jurídica. Rio de Janeiro: Elsevier, 2011.

SICOLI, José Carlos Meloni. A tutela penal do meio ambiente na lei n. 9.605, de 13 de fevereiro de 1998. Boletim IBCCRIM, nº 65 ed. esp., abr. 1998.

SIEBER, Ulrich. Programas de compliance en el derecho penal de la empresa. Una nueva concepción para controlar la criminalidade económica. In: ARROYO ZAPATERO, Luis; NIETO MARTÍN, Adán (dir.). El derecho penal económico en la era compliance. Valencia: Tirant lo blanch, 2013.

SILVA SÁNCHEZ, Jesús-Maria. Consideraciones sobre la teoría del delito. Buenos Aires: Ad-hoc, 1998.

- Honest vivere. InDret. n. 3, editorial, 2010. Disponível em: <http://www.indret.com/pdf/editorial2_es.pdf>. Acesso em: 05 jun. 2013.

La responsabilidad penal de las personas jurídicas en derecho español. In: SILVA SÁNCHEZ, Jesús-María (dir.); MONTANER FERNÁNDEZ, Raquel (coord.). Criminalidad de empresa y compliance. Prevención y reacciones corporativas. Barcelona: Atelier, 2013.

. Normas y acciones en Derecho penal. Buenos Aires: Hammurabi, 2003.

SILVEIRA, Renato de Mello Jorge. A ideia penal sobre a corrupção no Brasil: da 
seletividade pretérita à expansão de horizontes atual. In: Revista Brasileira de Ciências Criminais, v. 89, 2011.

Direito penal supra-individual: interesses difusos. São Paulo: Revista dos Tribunais, 2003.

SIRVINSKAS, Luís Paulo. Questões polêmicas sobre a responsabilidade penal da pessoa jurídica nos crimes ambientais. Boletim IBCCRIM, nº 65, ed. esp., abr. 1998.

STRATENWERTH, Günther. Derecho penal: parte general. Trad. Gladys Romero. Madrid: Edersa, 1982.

TANGERINO, Davi de Paiva Costa. A responsabilidade penal da pessoa jurídica para além da velha questão de sua constitucionalidade. Boletim IBCCRIM, nº 214, set. 2010.

TIEDEMANN, Klaus. Responsabilidad penal de personas jurídicas y empresas en derecho comparado. In: FRANCO, Alberto Silva. NUCCI, Guilherme de Souza. Doutrinas Essenciais: Direito Penal. v. 3, Parte Geral 2. São Paulo: Revista dos Tribunais, 2010.

- Nuevas tendencias en la responsabilidad penal de personas jurídicas. In: Dogmática penal del tercer milênio: Libro homenaje a los professores Eugenio Raúl Zaffaroni y Klaus Tiedemann. Lima: Ara, 2008.

TOLEDO, Francisco de Assis. Princípios básicos de Direito Penal. 5. ed. São Paulo: Saraiva, 2001.

VELÁZQUEZ VIOQUE, David. Responsabilidad penal de las empresas. ¿Cómo probar el debido control? Diario La Ley, n. 7794, Sección Tribuna, 9 fev. 2012. Disponível em: <http://www.diariolaley.laley.es>. Acesso em: 06 jun. 2013.

VENOSA, Silvio de Salvo. Direito Civil. v.1. 3.ed. São Paulo: Atlas, 2002.

VERVAELE, John A. La responsabilidad penal de y en el seno de la persona jurídica en 
holanda. Matrimonio entre pragmatismo y dogmatica jurídica. In: REYNA ALFARO, Luis Miguel (coord.). Nuevas tendencias del derecho penal económico y de la empresa. Lima: Ara Editores, 2005.

WELLS, Celia. Corporations and Criminal Responsability. New York: Oxford, 2001.

WELZEL, Hans. El nuevo sistema del derecho pena: una introducción a la doctrina de la acción finalista. Trad. José Cerezo Mir. Barcelona: Ariel, 1964.

YACOBUCCI, Guillermo J. Modelos de atribuición de responsabilidade penal en la empresa. In: YACOBUCCI, Guillermo J. (dir.). Derecho penal empresário. Buenos Aires: B de f, 2010.

ZAFFARONI, Eugênio Raul. PIERANGELLI, José Henrique. Manual de Direito Penal Brasileiro. São Paulo: Revista dos Tribunais, 2001.

ZULGADÍA ESPINAR, José Miguel. La admisión de la responsabilidad penal de las personas jurídicas: un pilar básico del moderno derecho penal económico. In: REYNA ALFARO, Luis Miguel (coord.). Nuevas tendencias del derecho penal económico y de la empresa. Lima: Ara Editores, 2005.

La responsabilidad penal de empresas, fundaciones y asociaciones: Presupuestos sustantivos y procesales. Valencia: Tirant lo blanch, 2008.

. Societas delinquere potest. Análisis de la reforma operada en el Código Penal español por la LP 5/2010, de 22 de junio. La Ley Penal: Revista de Derecho Penal, Procesal y Penitenciario, n. 76, nov. 2010.

ZUÑIGA RODRÍGUEZ, Laura. Bases para un modelo de imputación de responsabilidad penal a las personas jurídicas. Pamplona: Aranzadi, 2000.

La responsabilidad penal de las personas jurídicas em el Anteproyecto de Código Penal peruano de 2009.2 Disponível em: <perso.unifr.ch/derechopenal/assets/files/anuario/an_2009_08.pdf>. Acesso em: 13 abr. 
2012.

Responsabilidad penal de las personas jurídicas y criminalidade organizada. Consideraciones de urgência sobre la reforma al CP de 2010. In: MUÑOZ CONDE, Francisco. et al. (dir.). Un derecho penal comprometido. Valencia: Tirant lo blanch, 2011. 